\title{
LXXXVI. AMBON.
}

\section{Juli 1626. 1}

De onrust bleef op de Ambongroep aanhouden. De slechte betaling der kruidnagelen, het weren der vreemde kooplieden, gevoegd bij godsdienstige en nationale haat, waren overvloedige redenen. Van Speult tastte met rusteloozen ijver door en zijn opvolger in het Ambonsch bewind, Jan van Gorcum (1625-1628), ging zijne voetstappen drukken. Hidajat (vgl. hiervóór, bldz. 170) was gestorven in den aanvang van $1623^{2}$ (Onuitgegeven brief van Van Speult aan den G.G. 5 Juni 1623) en opgevolgd door den kimelaha Leliato, maar de verhoudingen verbeterden niet. In April $1625 \mathrm{kreeg}$ Van Speult versterkingen en een tuchtiging van Klein-Ceram vond plaats, nadat dáár een Nederlandsche sloep was afgeloopen. Terstond op het hooren van deze gebeurtenissen, bemoeide de sultan van Ternate zich meer dan gewoonlijk met de Ambonsche zaken. Ofschoon de onderhandelingen in den beginne allesbehalve wilden vlotten, werd toch in Juli 1626 een wapenstilstand getroffen. (TieleHeeres, Bouwstoffen, II, bldz. VI-XVII).

Contract, ende Artikelen, beraamd op de stilstand van wapenen, by de Heer Gouverneur, Jan van Gorcom, wegens den staat der Vereenigde Nederlanden, ende de Heeren Bewindhebberen der Vereenigde Oost-Indische Compagnie, onder het beleid van de Heer Gouverneur Generaal, Pieter de Carpentier, ter eenre, ende den Kimalaha Leliato, Stadhouder wegens den Koning van Ternate over de plaatzen Luciela, Loehoe, Cambello, ende andere onderdanen des gemelden Konings, ter andre zyde.

Eerstelyk, dat van nu voortaan alle hostile actien van vyandschap zullen ophouden, en niemand den anderen meer en zal beschadigen nog aan lyf, of aan goed, maar zullen met den anderen in vrede en vriendschap leven, en wy en onze onderdanen de plaatzen, waar over den Kimelaha 't gebied heeft, frequenteren, koopen en verkoopen, gaan en komen, zonder van iemand gemolesteerd te werden, gelyk mede de onderdaanen van de gemelde Kimelaha by ons, en onze onderdaanen, zullen geadmitteert werden.

Ten tweden, of het geviel, dat imand van de onderdanen, staande

1 Overgenomen uit Valentijn, II (Ambon), b, bldz. 58.

2 "Daya is jegenwoordich heel sieck ende naer men seyt geraeckt vande hant des Heeren, te weten de geheele sijde van 't lichaem als oock inde tonge, daer sijne $\mathrm{E}$. ons vrij hinderlijcker mede geweest is als met de wapenen, dat een rechtvaerdige straffe is." (Tiele, Bouwstoffen, I, bldz. 326).

7• Volgr. III. 
onder het gebied van de Heer Gouverneur van Amboina, imand van de onderdanen, sorteerende onder den Kimelaha, misdeden, ofte qualyk tracteerden, zoo zal de Gouverneur gehouden zijn de misdaders te straffen, dog onder zulken reserve, dat imand van des Kimelaha's volk daar by zal zyn, die ziet ofte hoord, of alles ook regtelyk toegaat; in al zulke manieren zal de Kimelaha met zyn onderdanen mede handelen, zoo imand zich aan de onze vergrypt.

Ten derden, belooft de Kimelaha, dat geene nagelen aan niemand zal verkoopen, nog van de zyne laten verkoopen, als alleen aan de Nederlanders van de bovengemelde staat, en voornoemde Compagnie.

De gevangenen, ende weggelopene slaven van wederzyden zullen blyven in verzeekeringe ter plaatze daer die zyn, tot 'er tyd toe dat daar nader aan wederzyde van gesproken, ende gehandelt zal werden.

Dat mede van nu voortaan, van wederzyde niet en zal getragt werden, om den een des anders onderdanen met list te onttrekken, ofte tot oproer te bewegen, maar yder zal zyn onderdanen na zyne wetten, ende goeddunken regeeren, zonder dat de eene ofte de andere party in des ander zaaken zal hebben te zeggen.

Wat vorder betreft de limiet-scheidinge, hoe wyd ende breed yders gebied strekt, zal blyven staan, tot dat by de Ed. Heer Gouverneur Generaal, ende den Konink van Ternate, ofte haar Ed. gecommitteerden, daar in zal worden geaccordeerd, ende goed gevonden, gelyk voords mede in alle pointen hier boven staande, ende die daar nog by ofte toegedaan zoude mogen werden. Dit bovenstaande belooven beide de partyen onverbreekelijk te onderhouden, zoo lang by den Ed. Heer Generaal, ende de Konink anders zal geordonneert werden, dien volgende hebben dit met eigen handen onderteikent, ter presentie van de ondergeschreven getuigen. Actum in 't Nederlands comptoir Hitoe ady 5 Juli A. 1626. Was geteekent Jan van Gorcum, C. W V S D. C W. I., ${ }^{1}$ 't merk van de Konink van Noessanivel ${ }^{2}$, Radja Soya ${ }^{2}$, 't merk van Don Andrea ${ }^{3}$, Manoel Castanho ${ }^{3}$, Paulo Gomes ${ }^{3}$, 't merk van Simon Baguwala 4, 't merk van Steven Ticera G V S gls, 't merk van den Capitein Hitoe, 't merk van de Jonge Pati Toeban, 't merk van Toetahatoe.

1 Deze letters zijn mij niet duidelijk.

2 Noesaniwe en Soya op Lei-Timor.

3 Inlandsche hoofden van Hative op het eiland Ambon, enz. (Vgl. TieleHeeres, Bouwstoffen, II, bldz. 148).

4 Inlandsch hoofd van Bagoeala. 


\section{MOLUKKEN.}

\section{7-20 December 1626. 1}

In de Molukken had - zooals veelal elders in den Archipel - de handelsstaatkunde der Compagnie groote ontevredenheid gewekt. De sluikhandel ten nadeele van haar monopolie tierde welig. Godsdienst-verschil voegde zich hier bij: „Hare Moorsche en onze Christelijke religiën zijn zoo onverzoenlijk en incompatibel, dat oprechte vriendschap niet mogelijk is." Verder hadden Ternatanen en Tidoreezen weinig lust, om terwille van de politiek der O.I. C., welke voor zich heil zag in het voortduren van den strijd tusschen deze beide inlandsche staatjes, van welke het laatstgenoemde aan de zijde van Spanje stond, dien strijd voort te zetten. In 1625 kregen de Nederlanders tijdelijk aanzienlijke versterkingen, waarna de zaken zich gunstiger voor hen lieten aanzien. Na het vertrek dier schepen begon de toestand zich weder in ongunstigen zin te ontwikkelen. Toch werd door verschillende besprekingen - tot welker gunstig resultaat de overweging, dat de Ambonsche aangelegenheden ook een vriendelijke verhouding tusschen de O. I. C. en Ternate wenschelijk maakten, zal hebben bijgedragen - bereikt, dat in December 1626 beloofd werd door Ternate, den oorlog met Tidore voort te zetten. (Vgl. Tiele-Heeres, Bouwstoffen, II, bldz. I-VI).

Accoort gemaect ende beslooten tusschen den Gougou 2 , Capiteyn Laout ter eender, ende den Hoccum Soyasius ${ }^{3}$, Sengagie Limetan ${ }^{4}$, noch vijff andere Sengagies deeses eylandts, mitsgaders de Sengagies van Motier, Tougouave ${ }^{5}$ ende alle d'overicheyden van Tarnaten ter andere syde, ten overstaen ende in presentie van d'heer Jacques le Febure, raedt van Indien, Gouverneur en directeur over de Moluccos, als oock int bijweezen van de Coningen van Gorontale en Pangesare ${ }^{6}$, twelck op Donderdach snachts den 17 December 1626 aan handen van gemelte heer Gouverneur gesamentlijcken beswooren hebben, die oock belooft heeft van weegen de Compagnie in presentie van synnen raedt ons met syn macht naer vermogen volgens d'oude contracten te assisteeren en behulpich te weesen.

1 Overgenomen uit Tiele-Heeres, Bouwstoffen, II, bldz. 92-94.

${ }^{2}$ Djogoegoe $=$ rijksbestuurder (op Ternate).

s Hoekoem, een aanzienlijk Ternataansch ambtenaar. Thans de titel van een „oppersten kamponghoofd." (De Clereq, Ternate, bldz. 324). Dus de hoekoem van Soahsio? (De Clereq, bldz. 26). Of moet achter Hoccum een komma worden geplaatst en is het volgende woord hier de titel van een Ternataansch hoofd? Dit komt mij waarschijnlijker voor.

${ }^{4}$ De sengadji van Limatahoe (Limetau?). (De Clereq, t. a. p. bldz. 150, 212).

${ }^{5}$ Toegoeai aan de westkust van Halmahera?

${ }^{6}$ Gorontalo en Pangasare of Tagoelandang stonden onder de opperhoogheid van Ternate. (Tiele-Heeres, Bouwstoffen, II, bldz. 93). 
Het is een yder kennelijck hoe hier in de Mollucques vier coningen sijn, namentlijck van Tarnaten, Tydoor, Baetsian en Gilole, waervan de twee lestgenomde door Godes bestieringe sonderlingh geen macht hebben, sulcx dat wij Tarnatanen ende die van Tydoor de machtichste sijn, welcken Coninck van Tydoor sich aen den Spaenjaert houdende, met derselver macht ons voor deesen verstroyt ende genoechsaem verdestrueert hadde, invoege wij genootsaect waeren ons tot de Hollanders (om van haer hulpe en assistentie te hebben) te keeren, die wij aen alle quartieren geresolveert hadden te soecken, soo in Amboyna, Banda, Java, Patania, Atchin als elders, doch vonden twee haerder scheepen d'een in Ambcyna ende d'ander op Java, die oock voorgenomen hadden in de Mollucques te comen, oversulcx hunne anckers lichtten en herwaerts quaemen, doer wiens hulpe wij alsdoen by malcanderen syn versamelt, 't landt als oock den Coninck in synen voorigen welstandt gebracht, jae waeren soo vereenicht dat alle tgundt sij oft wij goet vonden dadelyck int werck gestelt wiert, twelck alsoo continueerde totten tijde vanden Generael Reael, tsedert welcken tijt alhier drye verscheyden Gouverneurs ' geweest ende d'overicheyt, soo vande Hollanders als Tarnatanen seer verandert sijn, in voegen de Hollanders ons oft wij haer niet gelooft noch vertrouwt hebben, ende des lants saecken tusschen beyden soo syn blijven stilstaen, niet tegenstaende de Gouverneurs als oock wij overicheeden ende gemeente selffs den Coninck tot meermaelen hebben aengesprooken om de bevoirderinge des gemeenen lants ende Compangies saecken bij der handt te neemen, die sich daar niet met bemoyt maer met speelen en playsieren den tijt door gebracht heeft ${ }^{2}$, tot dat eyntelijck op heeden bij boven gemelte Gouverneur door sijn meenichvuldigen arbeyt ende betrachtinge de saecke soo verre is gebracht dat tot accoort ende treckinge van eene lijn gecommen syn, daer in den Gougou ende Cappiteyn Laout geenen beeteren middel om tot sulcx te commen wisten te practiseeren dan in deese vergaederinge ${ }^{3}$ voor te draegen hoe dat beyde soo Gougou als Cappiteyn Laout hunne ampten begeerden te abandonneeren en voortaen als gemeene citchils, (sonder eenich bewindt tlandt aengaende hun meer aen te trecken) te leven, ten waere sy Tarnataensche overicheyden met malcanderen alsnu in deze pitsiaeringe

1 Jan Dirkszoon Lam (1619-1621), Frederik de Houtman (1621-1622), Jacques Lefebvre of Lefebure (1622-1628).

2 Vgl. Tiele-Heeres, Bouwstoffen, II, bldz. 1.

s Van Gouverneur en Raad der Molukken. 
op des Compangies huys, daer vergaert waeren, resolveerden den oorloogh jegens den Spaenjaert en Tydorees aen te neemen ende tlandt in synen voorigen welstandt te helpen brengen, dat eyndelyck (hoe wel sy Tarnataensche overicheyden, te weeten den Hoccum Soysives, Sengagies ende andere daer langh tegen waeren ende sulcx sochtten wtte stellen), met malcanderen gesamentlijck toegestemt, over een gecommen, geresolveert, als boven verhaelt beswooren ende gemelte heer Gouverneur in presentie van synen Raedt daer op de handt gegeven hebben, om gelijck verhaelt den oorloogh jegens den Tydorees en Spaenjaert aan te neemen ende tlandt in synen voorigen welstandt te helpen brengen. Twelck den Coninck van Tarnaten voorengehouden synde, geapprobeert en voor goet gehouden heeft; doch alwaert schoon gemelte Coninck contrarie gedaen hadde was beslooten evenwel deese resolutie volcomen voortganck soude neemen . . . ${ }^{1}$

\section{JAPAN.}

$1627 ?^{2}$

In een schrijven van 1 December 1627 aan Cornelis van Neyenroode, ons Opperhoofd voor den bloeienden Japanschen handel te Hirado ${ }^{3}$, maakt Pieter Nuyts, onze gouverneur van Formosa, melding van een opdracht der Japansche centrale regeering aan den gouverneur van Hirado, om den Nederlanders den handel te blijven vergunnen op den ouden voet. Deze opdracht dagteekende toen van een drietal maanden geleden. Zij was te opmerkelijker, omdat de Japanners toen allesbehalve den Nederlanders gunstig waren gestemd, daar de Nederlanders door hooge tollen, enz. den handel der Japanners op Formosa, voor dezen van groote beteekenis, trachtten te verhinderen. Nuyts was juist van Augustus tot November 1627 gezant geweest van den Gouverneur-Generaal aan het Japansche Hof en, ofschoon zijne zending niet het gewenschte resultaat had ten opzichte van den Formosaanschen handel, kan hij toch op de hoogte geweest zijn eener dergelijke opdracht. (Vgl. Nachod, Japan, s. 189-199, LXXIX). Waarschijnlijk ${ }^{4}$ is onderstaand stuk een afschrift dezer opdracht, verstrekt aan de O. I. C.

1 Wat nog volgt, is een gedeelte van de resolutie van Gouverneur en Raad, waarin deze overeenkomst is opgenomen, dat echter van de overeenkomst zelf geen deel meer uitmaakt.

${ }^{2}$ Uit het archief der familie Huydecoper van Maarsseveen.

s 1623-1632 was deze ons Opperhoofd van den handel te Hirado.

4 Waarschijnlijk: met zekerheid is het niet te zeggen. Het is ontleend aan een document van 1693 (zie hiervóór, bldz. 94, noot 2). De opdracht moet 
Dat aen d'Hollandsche Cap $^{t}$ soo in Meaco ${ }^{1}$ als elders in wat plaets van Japan hij begeert, toegestaen sal wesen om coopmanschap te drijven, en dat $\mathrm{d}^{\prime} \mathrm{H}^{\mathrm{r}}$ van Firando hem sulx onverhindert sal toelaten; maer alleen goede toesigt houden, dat de Paepsche of wel Portugese religie niet door d'Hollanders werd verbryd.

\section{CHINA-FORMOSA.}

\section{0ctober 1628. ${ }^{2}$}

Al spoedig na onze vestiging op Formosa (Thaiwan) $s$ ontstond op dit eiland voor ons een handel van beteekenis, vooral in Chineesche en Japansche producten; het eiland bleef, wat het was geweest, een centrum voor den handel van Oost-Azië, thans echter zooveel mogelijk hier door ons gemonopoliseerd. Het stuk grond, waarop „onze stadt" zoude worden gesticht en dat gekocht werd van de "ingelande", "die van Sintang, $(=$ Sinkan?)", lag aan de Zuidwestzijde van het eiland. Het fort heette eerst Oranje ; de nieuw begrepen stadt": Provintie. In 1627 werden beide genoemd Zeelandia, op last der Bewindhebbers. Men trachtte, nu men zelf op de kust van China geen handel mocht drijven, de Chineezen te bewegen, op onze vestiging te komen handelen, zooals dan ook door de Chineezen in het vooruitzicht was gesteld bij de onderhandelingen omtrent het verlaten der Pescadores. Japanners daarentegen maakte men de commercie moeilijk, door hooge tollen, enz. (Zie hiervóór, bldz. 213). Aan de andere zijde waren de Chineezen, welke vroeger gewend waren de Thaiwansche producten (hertevellen, enz.) op het eiland op te koopen, ,zeer jaloersch," dat de bewoners daarvan, welke in de omgeving onzer sterkte woonden, dagelijks daar kwamen handelen.

Een plaag voor den handel was het bedrijf van zeeroovers, Chineezen veelal, op de kust van China zoowel als op die van Formosa. Hun aanvoerder in die dagen, welke in de stukken der O. I. C. steeds Iquan

natuurlijk zijn gegeven vóór 1641, toen onze factorij naar Desima werd verplaatst. En vóór 1641 weet ik haar slechts te plaatsen in 1627.

In den brief van 1693 staat nog vóór de insertie dezer opdracht: „In den jaere $16 \ldots$ is door d'hooge overigheyd uyt Jedo aen $d^{\prime} h^{r}$. van Firando een ordre gegeven, hoedaenig d'Hollanders in syn land met hun handel te gedragen, en waer nae haer te reguleren sullen hebben."

1 Kioto, toen de residentie van den Mikado.

: Uit het Contractboek.

3 Thaiwan (thans ook Tainan geheeten) op $22^{\circ} 59^{\prime}$ is de plaats onzer vestiging geworden. Het geheele eiland werd eveneens zoo genoemd, ook Packan. (Vgl. Groeneveldt, China, bldz. 202, noot 2). Kan deze naam ook zijn afgeleid geworden van het kustplaatsje Pakkang aan de Westkust (Hokuko)? 
wordt genoemd, 1 een stoutmoedig en bekwaam avonturier, maakte de omliggende zeeën ten hoogste onveilig en het gelukte noch aan de Chineesche autoriteiten, noch aan de Nederlandors, hem de baas te worden. Amoi werd in 1628 door hem veroverd en verwoest. Nuyts, de gouverneur van Formosa (1627-1629), trachtte met hem in vriendelijke verhouding te komen, om het groote belang, dat de O. I. C. daarbij had. Hij bood hem vriendschap aan, en Iquan, daartoe niet ongenegen, wilde zelf ons wel van Chineesche koopwaren voorzien, maar hij bleef de Chineesche kooplieden beletten, met de onzen te komen handelen. Intusschen ging Iquan over in dienst van de Chineesche regeering (Mingdynastie) en hij trad thans zelf tegen de zeeroovers op. Hij ontmoet Nuyts vóór Amoi, komt bij hem aan boord en wordt daar verraderlijk gevangen genomen tot hij verlof geeft voor den vrijen handel der Chineezen (een daad, ten zeerste door de Batavische autoriteiten afgekeurd en die een der vele redenen is geweest, waarom Nuyts in ongenade is gevallen). Toen Nuyts echter vernam bij deze gelegenheid, dat hij thans "groot mandoryn van Amoy en admiraal van de zee" was geworden, vindt hij beter met hem een verdrag te sluiten, wat plaats vond op 1 October 1628. Bewindhebbers der O. I. C. beschuldigden later Nuyts, dat hij "tot zijn eygen voordeel met den zeeroover Iquan geprocedeert" had. (Vgl. Onuitgegeven missives van G.G. \& R. aan Bewindhebbers, 27 Jan., 14 Aug. 1625, 3 Febr. 1626, 9 Nov. 1627, 8 Jan., 3 Nov. 1628; van G. G. \& R. aan Sonck $13 \mathrm{Mei} 1625$, aan Nuyts $18 \mathrm{Mei}, 23 \mathrm{Mei}, 26$ Juni 1628; onuitgegeven Verhael van 't gepasseerde op de Cust van China, op 18 Dec. 1627; onuitgegeven instructie voor Nuyts, $10 \mathrm{Mei} 1627$, onuitgegeven missive van Nuyts aan Coen, 26 Oct. 1628; onuitgegeven brieven van Bewindhebbers aan G. G. \& R. 18 Oct. 1629, 27 Aug. 1630, 23 Nov. 1631; Dagh-Register 1624-1629, bldz. 145, 334; Kronijk Historisch Genootschap, 1853, bldz. 194, 204; Campbell, Formosa under the Dutch, p. 38 f., 41; Boulger, China, p. 123.)

Accoordt getrocken tusschen d'H $\mathrm{H}^{\mathrm{r}}$ Pieter Nuijts, Raedt van India ende gouvern ${ }^{r}$ over t' eylandt Formosa ende tfordt Zeelandia ter eenre ende Iquan, overste mandorijn van de provintie van Aymoy ende admir van de Chineese zee, ter andere zijde.

Ick, Iquan, beloove, drie aghter eenvolgende jaeren aen $\mathrm{d}^{\prime} \mathrm{Ed} \mathrm{d}^{\mathrm{e}}$ $\mathrm{H}^{\mathrm{r}}$ Gouver $^{\mathrm{r}}$ Nuijts jaerlycx $1400 \mathrm{p}^{\mathrm{l}}$ goede schoone zyde tot 140

1 Iquan was vroeger tolk der O. I. C. te Thaiwan, maar schijnt uit vrees voor de Japanners gevlucht te zijn en zeeroover te zijn geworden. In Chineesche bronnen wordt hij meestal Cheng Chi-lung genoemd. Hij was gehuwd met een Japansche vrouw en uit deze verbindtenis sproot de bekende Koxinga. Over de llevensgeschiedenis van dezen merkwaardigen man zie men, behalve de bronnen in den tekst genoemd, o. a. de volgende werken: Riesz, Formosa, S. 422; Campbell, Formosa under the Dutch, p. 383, 405, 459; Davidson, Formosa, p. 8, 30 f. 
teyll 't picoll in Zelandia te leveren. Wanneer $\mathrm{d}^{\prime} \mathrm{H}^{\mathrm{r}}$ Gouver ${ }^{\mathrm{rs}}$ scheepen die hier in de revier Chincheo ${ }^{1}$ sullen komen halen, ben ick te vreden, dat men 10 teyll $\mathrm{p}^{\mathrm{r}}$ picoll sall korten ende 130 teyll mij betaellt sullen worden.

Jtem $5000 \mathrm{p}$ goedt droogh wit ende onvervalsght poeijer suyker tot $3 \mathrm{R}^{\mathrm{n}}$ ijder picoll.

$1000 \mathrm{p}^{1}$ geconfijte gember ende well geconditioneerdt, niet harigh nogh swardt, maer groote helldre klauwen ${ }^{2}$ tot 4 teijll picoll.

Nogh 4000 witte gielems a 14 maes $^{3}$ yder.

Jtem 1000 goede schoone en hoogh van coleure roode gilems a 19 maes ijder.

Vorders is geconditioneerdt ende besprooken, dat alle kooplieden met haer eygen joncken naer Zeelandia, neffens allderhande koopmanschappen, sonder onderscheijt sullen mogen varen, zonder door mijne soldaten eenighsints in haere vojagies offte goederen verhindert te worden; ende die met mijne joncken willen haere goederen oversturen, zullen daertoe, mits betalende behoorlijcke vraght, gelicentieerdt worden.

Wyders behoorle ${ }^{4}$ ick, dat ick alle cooplieden, die aen de Japand ${ }^{\text {rs }}$ eenigh geldt schulldigh sijn, hare namen daeraff bekomen hebbende, zall doen betalen ende voor de Comp ${ }^{e}$ 't gelt jnvorderen, als mede van gelijcken by alle wegen die te-aghterheijdt ende de schade die de Comp ${ }^{e}$ compt te leijden by den persoon van Simsouw. ${ }^{5}$

Jnsgelycx ben ick te vreden, van de Compe te ontfangen 2000 picoll goede $\mathrm{pp}^{\mathrm{r}}{ }^{6}$, die jck sall betalen $11^{\mathrm{e}} \mathrm{R}^{\mathrm{a}}$ picoll.

Ende opdat men versekert zij, dat dit contract van mijnder zyde zonder fraude offt eenigh arghlist promptelijck in allen deelen zall aghtervolght ende naergekomen worden, is verdragen dat mijne broeder Sisia ende Teontij, mijnen cap $^{n}$, met de $\mathrm{H}^{\text {re }}$ Gouvern $^{\mathrm{r}}$ als ostagiers ende versekeraars deses contracts naer Zelandia vervoerdt zullen worden.

Ende sall t' selve contract van mynder zyde deuren den tijt van

1 Chinchieu: de rivier van Amoi. (Vgl. Groeneveldt, Nederlanders in China, bldz. 16 , noot 1 ).

${ }^{2}$ De wortelstok?

3 Een tael (= tien mes of maas) is ongeveer f 4.- (Vgl. ook Valentijn, IV, 1, bldz. 357).

4 Schrijffout voor "beloove"?

5 Vgl. Dagh-register, 1624-1629, bldz. 246 (9 April 1626).

6 Peper.

7 Of Hisia? 
drie aghtereenvolgende jaeren, dogh heefft $\mathrm{d}^{\prime} \mathrm{H}^{\mathrm{r}}$ Gouvern ${ }^{\mathrm{r}}$ Nuijts besprooken, dat [hij] van dese handelinge d' $\mathrm{Ed}^{\mathrm{e}} \mathrm{H}^{\mathrm{r}}$ Gouvern ${ }^{\mathrm{r}}$ gener $^{\mathrm{l}}$ Coen, op $\mathrm{Bat}^{\mathrm{a}}$ resideerende, zall met den eersten adviseeren ende zoo zyn gem $^{\mathrm{e}} \mathrm{Ed}^{\mathrm{e}}$ tselve geliefft allsoo te approbeeren, geloofft ${ }^{1} \mathrm{~d}^{\prime} \mathrm{H}^{\mathrm{r}}$ Gouver $^{\mathrm{r}}$ Nuijts, dat alles van zynder zijde ook promptelijck zall naerkomen worden ende des neen, zall dit contract met het eerste jaer eyndigen.

Actum $\mathrm{p}^{\mathrm{mo}}$ 8ber $\mathrm{A}^{\circ} 1628$ jnt jaght Texell, geanckert leggende in de reviere van Chincheo voor Aymoij. ${ }^{2}$

\section{AMBON.}

\section{October 1628 S. R. ${ }^{3}$}

De invloed en het gezag der O. I. C. op de Ambon-groep waren gaandeweg aanzienlijk vermeerderd. Europeesche mededingers had zij daar niet meer ernstig te duchten, nu ook de Engelschen sedert de bekende gebeurtenissen van 1623 van daar waren opgebroken. Wèl daarentegen inlandsche potentaten: o. a. den sultan van Makassar, die van de handelspolitiek der Compagnie, werd zij volkomen doorgezet, - terecht - schadelijke gevolgen vreesde voor den handel en de welvaart van zijn rijk, voor eigen invloed en macht en voor de uitbreiding van den Islam; en den sultan van Ternate, die zijn oude en gevestigde rechten op sommige streken dezer eilandengroep bedreigd zag bij het voortgaan van der Nederlanderen invloed en gezag. Het spreekt wel van zelf, dat hij geen werkeloos toeschouwer bleef, toen de staatkunde der Compagnie tot geschillen en bloedige botsingen leidde tusschen haar en de Amboneezen. (Vgl. Tiele-Heeres, Bouwstoffen, I, II, passim). Zoo verscheen in de laatste helft van 1628 opnieuw een vertegenwoordiger van Ternate's sultan in de Ambonsche wateren, nl. de zeer invloedrijke prins Ali, de Ternataansche kapitein laoet of vlootvoogd. Hij bewerkte, dat onderstaand verdrag tusschen de partijen werd gesloten, waardoor een poging werd in 't werk gesteld om de geschilpunten te vereffenen: den prijs der nagelen, de betaling in contant of in goederen, de godsdienstpropaganda, de grensregeling, enz. (Vgl. t. a. p., II, bldz. XLI, v., enz.; Dagh-Register 1624-1629 bldz. 377, enz.)

\section{Contract by d' $\mathrm{H}^{\mathrm{r}}$ Gouvern ${ }^{\mathrm{r}}$ Philip Lucassen ${ }^{4}$ met} die van Amboyna gemaeckt.

\section{Belooft.}

2 Coen heeft deze overeenkomst niet kunnen goedkeuren. Aan Nuyts' opvolger als gouverneur van Formosa, Hans Putmans, gaf de G. G. te kennen, dat deze zich niet aan het accoord moest houden, omdat het onvoordeelig was voor de O. I. C. Putmans moest zooveel mogelijk trachten de zeeroovers te verdrijven en te bestrijden. (Onuitgegeven instructie voor Putmans, 24 April 1629).

3 Uit het Contractboek.

4 1628-1631. 
Nae dat ontrent de zes a 7 jaeren gepasseerdt seker different tusschen den gouvern ${ }^{\mathrm{r}}$ wegen de prince van Hollandt, den stadthouwer ende de hooffden van de omliggende eijlanden ende dorpen van Amboyna ende Ceram wegen den koninck van Ternate is ontstaen, soo vougen ${ }^{1}$ niet alleene in oneenigh ${ }^{t}$ met den anderen geleefft, maer de saeken zoo verre verlopen zijn, dat tot de feijtelijckh ${ }^{t}$, termen van hostiliteijt, consequentelijck ruine ende verderfft van beijde volckeren ende vrughten geprocedeert hebben ${ }^{2}$, zonder noghtans met voorweten ende speciale ordre van hare respective souvaraine daertoe gelast te wesen ${ }^{3}$; daer over in aghtinghe ende memorie genomen hebbende, d'onse voor desen bondige alliantien ende geraemde contracten tusschen den gemelte prince van Hollandt ende den koninck van Ternaten gedaen heefft ${ }^{4}$, ons ${ }^{5}$ buyten redenen ende arrogants gedoght, de vassalen ${ }^{6}$ uijt eygen motijff niet alleene questie moveren ${ }^{7}$, maer selffs tot den oorlooge vervallen zouden, dienvolgende willende in desen voorsien, weeren alle misverstanden ende calumineuse gerughten uijt onse landen van Amboyna ende Ceram voorn ${ }^{t}$, den koninck jn Ternaten, sullthan Adill Amerill Momena Hamsia Nasseron Halla Scha ${ }^{8}$, gesamentlijck den Tarnataensen Raedt ende de respective stadthouders beslooten, gelast ende geauthoriseerdt, aen den admiraell van der zee quitchill Aly ${ }^{9}$, om met een armada correcorren sigh te transporteeren in onse landen van Amboyna ende Ceram ${ }^{10}$, omme alldaer onsen persoon te representeeren ende uijt craght onser verleende commissie ende brieven van credentie affte handelen, reghten, bevreedigen alle geschillen ende differenten, in die quartieren bij verloop van tijt ontstaen, ende weder als oude vrunden, ende bondtgenooten jn vreede ende ruste te doen leven: soo ist dat wij, quitchill Aly, bekledende sijn Maij $^{t}$ persoon, int casteell van Amboyna geconvoceerdt hebben den stadthouwer des Koninghs, Leliatoe ${ }^{11}$, de

\footnotetext{
1 In de lezing bij Valentijn, Ambon, b, bldz. 75: "invoegen."

9 Vgl. Tiele-Heeres, Bouwstoffen, II, bldz. VII, v., enz.

$s$ Wat eene wel niet geheel juiste bewering is.

4 Valentijn: "gemaakt hebben."

5 Valentijn: „zoo zijn."

"Valentijn: "en met arrogantie gedagte vasallen."

7 Valentijn: "met ons in quaestie geraakt."

s Sultan Hamdja of Hamza (1627-1648).

9 De kapitein laoet kaitsjil Ali.

${ }^{10}$ Bouwstoffen, II, bldz. XLI, 145, enz.

11 Bouwstoffen, II, bldz. VII, v., XLI, v., enz.
} 
respective landtvooghden van Loehoe, Lissydy. Cambelle, de hooffden van omliggende eylanden ende dorpen van Oleesiva ende Oleelyma, gesamentlijck des Koninck in Ternates onderdanen, ten overstaen ende als getuygen daertoe geroepen alle principale mijne bijgevoegde rade uyt Ternaten als Mackjan ' ter eener, ende d'E. Philippo Lucas, gouvern ${ }^{\mathrm{r}}$ van t' Cassteell ende dependentie van Amboyna, benevens die van sijn E. raden als de naturelen ${ }^{2}$ uyt den landtraedt, wegen de Hoge Mogende $\mathrm{H}^{\mathrm{n}}$ Staten Gener ${ }^{1}$, den heere prince van Orangien, mitsgaders de $\mathrm{Ed}^{\mathrm{e}} \mathrm{H}^{\mathrm{n}}$ bewinthebberen der Geoctroijeerde Comp ${ }^{\mathrm{e}}$ der Vereenighde Nederlanden ter andere, dewelcke ijder int bysonder gesustineerdt, beweerdt ende geprobeerdt hebben sodanige differenten, verschillen, gepasseerde actien ende onheijlen. Jn vougen, naer deselve aen wederzyden grondigh verstaen, wij quitchill Aly ende gouvern ${ }^{\mathrm{r}}$ Philippo Lucas voorengem ${ }^{\mathrm{t}}$ met voorweten ende toestemminge van den stadthouwer, landtvooghden ende de hooffden respective van Oleesyva ende Olelima, groodt ende cleyn, onderdanen van Sijne May ${ }^{\mathrm{t}}$, zijn overeengekomen, geaccordeert ende vereenight, bevreedight onder de artykelen naer gementioneerdt zynde ende luijdende:

Eerstelyck belooven wij, gouvern ${ }^{\text {rs }}$ ende wij alltsamen, hoofden van Olysiva ende Olilyma, te vergeten ende niet meer inde gedaghten te nemen alle gepasseerde verschillen en misverstanden, sonder van deselve yets te moveren, maer sullen met den anderen woonen ende handelen als getrouwe vrienden ende bondtgenooten, sonder lightvaerdigh eenige calumineuse rapporten t'accepteren. Voorders zall 't des Koninghs onderdanen, Mahumetissten, vrij tot haer gelieffte staen om aent Cassteell offte andere plaetsen haren handell te drijven; van gelijcken sullen de Nederlandsche vassalen, 't zij dan Christenen ofte Mahumetissten, vrij op alle des Coninghs plaetsen haren handell doen.

Ten anderen belooven wij gesamentlijcke hooffden van Loehoe, Combelle, Lissidy, Hittoe [ende ${ }^{3}$ omliggende eylanden ende dorpen, dat wij aen de Nederlanders alleen sullen verkoopen ende doen

1 Bouwstoffen, II, bldz. 145.

2 De inlandsche leden van den „landtraedt" op Ambon, welke recht sprak in burgerlijke en strafzaken, waarin alleen inlanders waren betrokken. Hij werd voorgezeten door den Gouverneur en bestond verder uit Europeesche en inlandsche leden. (Heeres, Ambon in 1647, bldz. 550, v. in deze Bijdragen, XLVII).

s Valentijn, bldz. 76. 
leveren nu ende naer desen droogh, schoon ende well geconditioneerde, alle onse giroffi nagelen volgens d'oude contracten ende sullen ons voor de Portugeesen bhaer betalen $60 \mathrm{R}^{\mathrm{a}}$ van aghten, dienvolgende ons mede verpligtende, aen niemandt anders als de Nederlanders eenige nagelen te vercoopen offte leveren.

Voorder belooven wij voornt. aghter volgende de ordre des Konings ende die van Quitchill Aly, representerende Zijne May ${ }^{\mathrm{t}}$. persoon, dat wij niemandt admiteeren, alliantien met deselve aengaen, handell drijven noghte acces op onse stranden gedoogen eenige vreemdelingen offte coopluyden, 't zij dan Europische offte Indiaense natien, directelyck offte jndirectelyck; ende t'zoo 't gebeurde, eenige quaedtwillige hooffden offte dorpen dese gemelte des Konings last niet en aghtervolgende, dien volgende toegangh aen eenige vreemdelingen [gedoogden] ', zallt aen den Gouvern ${ }^{r}$. en Kimelaha geoorlofft wesen, deselve vreemdelingen met haer vaertuygh vijandelijck aen te tassten ende de dorpen die dese des Konings ordre niet t'prompt aghtervolght hebben, mede vermogen te verdestrueeren.

't Is sulcx dan, den Koningh van Macassar jegens den Koninck van Ternate in termen van oorlooge jegens den anderen staende, ${ }^{2}$ diervolgende aen alle sijne Mayt. onderdanen op 't hoogste bevoolen ende aen sijne bondgenooten versoght heefft, de geene ${ }^{3}$ Maccassaren overall te water ende te lande te vervolgen ende jst mogelijck te distrueeren.

Jngevalle den koningh van Maccassar eenige maght offte armada in die quartieren van herwaerdts over sende, om eenige jnvasie offte overlast in d'eylanden offte plaetsen des Koninghs onderdanen te doen, heefft de gouvern ${ }^{r}$. van 't casteell Amboyna van zijne zyde beloofft, derselver met presente ende toecomende maght jegens soodanige oppressie te helpen protegeren; van gelijcken zoo eenige maght van vyanden 't Cassteell oft desselffs onderdanen quamen offenceren, belooven wij gesamentlijck, van Olisiva ende Olylyma, gem $^{\text {te }}$ gouvern $^{\mathrm{r}}$ in alles naer ons vermogen te hellpen ende assisteren.

Soo het gebeurde, dat eenige plaetsen offte dorpen sigh jegens zyne heere vergrepen offte quamen te rebelleren, sullen den Gouvern ${ }^{r}$ ende stadthouwer des Konings deselve reghten offte well naer gelegenh $^{t}$ vyandelijck aentassten ende tot gehoorsaemh ${ }^{t}$ performeren;

1 Valentijn.

' Vgl. Tiele-Heeres, Bouwstoffen, III, bldz. XXXVI, XLVII, v.

3 Valentijn: „de gemelde." 
van gelycken beloofft den Gouvern ${ }^{r}$ die van Loehoe, Combelle, Lissidy, soo om rys offte andere menudentien ${ }^{1}$ moghten verlegen wesen, deselve tot haren noodtdrufft te assisteren ende bij de respective coopluyden wadt civillder te doen verkopen als ordinaijre ende courandt vercoght word, namentlijck dat wegen den lossen rijs haer een gantangh ${ }^{2}$ op yder $\mathrm{R}^{\mathrm{a}}$ meer, alst aent Cassteell vercoght wordt, zall geleverdt werden. Jnsgelijcx den rijs in betalen ${ }^{3}$ voor twee een halve $\mathrm{R}^{\mathrm{a}}$ van 8 jder bale.

Noopende den prijs van den Cormandellse en Suratse kleeden heefft den Gouvern ${ }^{r}$ mede geaccordeert te aghtervolgen de lijste ende prijs daerover in Ternate geraemt, behoudentlijck dat geen in betalinge voor nagelen sullen opgedrongen worden, maer 't sall t'selve tot haer eygen gelieffte wesen om well contant offte kleeden daervoor aen te nemen.

Voorders zoot geviele, eenige Nederlanders offte naturelle Amboneesen naer Loeho, Lissidy, Cambelle offte eenige andere des Konings plaetse quamen over te loopen, ende zullen deselve niet vermogen, Mahumetist te maeken, maer zall den Stadhouwer offte andere hooffden gehouden wesen, deselve weder aen 't Cassteell te seyuden. Jnsgelijex en sall den Gouvern ${ }^{\mathrm{r}}$ geen overgeloopen Mahumetisten vermogen Christen te maecken, maer als vooren mede den stadthouder des Konings overleveren. Soo daer eenige slaven quamen aent Cassteell loopen, en sall den Gouvern ${ }^{\mathrm{r}}$ niet vermogen, deselve Christen te maeken, maer deselve geboeijt weder aen den Stadthouder zeynden; desgelycx en sall den Stadthouder geen verloopen slaven van 't Cassteell [vermogen] 4 Mahumetist te maeken, maer als vooren gebonden den Gouvern ${ }^{\mathrm{r}}$ doen overleveren ende sullen sulcke, die [de] slaeff offte slavinne als leijffeijgene toecompt, voor berghloou van deselve vijffthien $\mathrm{R}^{\mathrm{a}}$ van 8 gehouden wesen te betalen.

Voorders jngevalle eenige dorpen offte particuliere persoonen uijt hun eygen moetwill offte motiff hun onderwonden te rooven, ymandt verradelijck te moorden offte de landt vrughten te verderven aen wiens, de Gouvern ${ }^{r}$ offte des Kimelahas, onderdanen tselve geschiede ende den Gouvern ${ }^{\mathrm{r}}$ aen den Stadthouder daerover justitie versoghte offte dan dat den Stadthouder over gelycke delict reght van den

\footnotetext{
1 Valentijn, bldz. 77: „andere zaaken."

"Inhoudsmaat of gewicht. In Valentijns tijd als gewicht: „houd $4 \frac{1}{2}$ pond." (Valentijn, IV, 1, Batavia, bldz. 360).

s Schrijffout voor "balen" (Vgl. Valentijn, Ambon, b, bldz. 77).

4 Valentijn, bldz. 77.
} 
Gouvern $^{\mathrm{r}}$ vorderde ende dat zoo well van d'een als de andere zijde geen behoorlijcke refactie ', ende opreghte justitie gepressteert werde, zullen naer verloop van een maendt naer dato van de jnsuniatie, t'waere dan den Gouvern ${ }^{r}$ offte Stadthouder, den zelven vermogen te destrueeren ende hun sellven reghten, zonder dat bij de respective gesustineerdt werde, daer in qualijck offte [niet] ${ }^{2}$ conform d'unnie gehandelt ware; behoudentlijck noghtans, soo daer eenige dorpen, met voorgemeldte moedtwilligh ${ }^{t}$ jngenomen geweest zijnde, sall soodanige revengie jegens de particuliere plaetsen geexcecuteert ende jnt werck gestelt worden, zonder dat d'andere plaetsen tsellve mede subject offte den last van d'andere gemeen sullen wesen.

Soo daer ijmandt versoghte, eenige schullden, t'ware comptant offt kleeden, van de koopluijden in [de] respective dorpen te maken, onder conditie deselve opt gewas offte eenige tijt van maenden te betalen ende naer d'expiratie van den tijt hun absenteerden, zall den Gouvern ${ }^{r}$ offte Stadhouder gelicentieert wesen ende vrijstaen, den gemelten debiteur te doen opsoeken ende aen de dagh brengen ende deselve so lange in private apprensie offte geboeyt houden tot aller ${ }^{2}$ tijt de schullt behoorlijck affgeleijdt ende betaelt is.

Voorder sullen den Koninck van Tarnates vassalen tot gerieff van den handell in rijs offte kleeden offte tot preservatie van de vrughten ter plaetse daer sulcx vereijscht wẹrdt, opt versoek van den Gouvern ${ }^{\mathrm{r}}$ gehouden wesen aen te wijsen seekere bequame plaetse, daer de jnwoonders ter eerster instantie een gerieffelijcke wooninge buijten cossten sullen moeten maeken, dogh naert selve eens behoorlijck in effecte gebraght ende aen de Nederland ${ }^{\text {rs }}$ overgelevert is, zall daernaer den Koopman ${ }^{4}$ gehouden wesen, t'sellve tot eijge kossten all 't geene daeraen gebreeken moghte doen repareeren.

Jnsgelijex soo 't geschiede, eenige verschill quame te ontstaen ter oorsaeke der respective coopluijden niet opreght met de jnwoonderen handellden offt eenige overlast booden ${ }^{5}$, tware dan jnt stuck van den godtsdienst, vrouwen ende kinderen, offte dat de soldaten eenige quetstie moveerden, en zall men ter oorsake van dien niet mogen tot de wapenen procederen, maer t'zellve den Gouvern ${ }^{r}$ aen-

1 Valentijn, bldz. 77: „satisfactie.”

2 Valentijn, bldz. 77.

s Valentijn: "tot der tijd."

4 Nl. de Nederlandsche vertegenwoordiger der O. I. C. (Vgl. Valentijn, bldz. 77).

5 Valentijn: "deden." 
geven, ten einde naer behoorlijcke jnspective ${ }^{1}$ van de saeke genomen hebbende, beloofft den Gouvern ${ }^{\mathrm{r}}$ deselve naer egigentie ${ }^{2}$ ten overstaen vant schansche (sic) dorp publijck te doen corrigeeren.

- Belangende 't stuck van ijders onderdanen ende jurisdictie, hebben den voorgemelte cap $^{\mathrm{n}}$ laout ende den Gouvern ${ }^{\mathrm{r}}$ aengenomen, t'sellve bij de handt te nemen, op liet gevoeghlijckste ende opreghte te confereren ende [het] verhandellde van die beloofft den Cap ${ }^{\mathrm{n}}$ laoudt t'sellve den koninck jn Ternate ende den Gouvern ${ }^{\mathrm{r}}$ aen de Gouvern ${ }^{\mathrm{r}}$ Gener $^{\mathrm{l}}$ te exhiberen, ten eijnde tselve bij hun respective wierde geapprobeerdt ende van waerde gehouden; naer welcke voorgaende approbatie deselve in dese quartieren aen de Gouvern ${ }^{\mathrm{r}}$ ende Stadhouder [mitsgaders] ${ }^{3}$ de vordere hooffden des Konings onderdanen overgesonden werden, om ijder dienvolgende zijne onderdanen te righten, behoudentlijck dat ijder, den Gouvern ${ }^{\mathrm{r}}$ offte Stadthouder, in volcomen bezit sall houden soodanige plaetsen ende jurisdictie als ten eynde deser ijder pretendeert ende in possessie heefft; zonder dat d'een den anderen onderdanen eenige overlast sall vermogen te doen. Mahumetisten sullen geen Christenen ende Christenen zullen geen Mahumetisten vermogen gemaeckt worden. Except des zelffs onderdanen, sall tot eijgen gelieven staen, deselve naer syne maniere te buijgen ende t'zoo t'geviele, dat des Gouvern ${ }^{\mathrm{rs}}$ onderdanen offte Stadthouders vasalen des Konings hare resp ${ }^{e}$ hooffden niet behoorlijck gehoorsaemden, zall den d'een anderen op sijn versoek assisteren; dogh soo hem maghtigh ende gedisponeerdt vanden, t'sellve alleen te verrighten ende uijt te voeren, sall d'een op d'anders proceduren niet vermogen te reprocheren.

Dit is, dat wij cap $^{n}$ laout, quitchill Aly, ten overstaen van alle mijne raedtspersoonen, respective hooffden van Ternate ende Macquian ende den Stadthouder, landtvooghden ende hooffden, Oolesiva ende Olilyma, van Amboyna ende Ceram gesamentlijck des Mayt ${ }^{\mathrm{s}}$ van

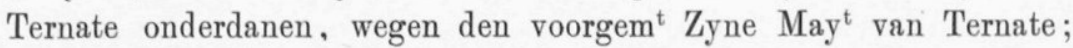
ende den gouvern ${ }^{r}$ Piliph Lucassen uyt den naem van den gouvern ${ }^{r}$ gener Jan Pieterszoon Coen, gesamentlijck die van onse ende die uijt den landtraedt van Amboyna, wegen de Hoogh mogende $\mathrm{H}^{\text {ren }}$ Staten Generaell, de prince van Orangie ende de bewinthebberen der Vereenighde Geoctroyeerde Oosstindische Comp ${ }^{e}$ van de Neder-

1 Valentijn: "inspectie."

2 Valentijn: "exigentie."

s Valentijn, bldz. 77 . 
landen goedgezonden, geunieerdt ende beslooten hebben, gelijck d'een d'ander belooven, 't selve met getrouwe ende opreghte gemoederen te onderhouden ende doen onderhouden. In teycken van dien hebben wij, cap ${ }^{\mathrm{n}}$ laoudt quitchill Aly ende gouvern ${ }^{\mathrm{r}}$ Philip Lucas yder particulier hier onder onse gewoone signature ende zegelen gestelt, gelyck wij mede aen den stadhouder van Loehoe, de landtvoogden ende hooffden Olysiva ende Olylyma van Amboyna ende Ceram voorgemeldt, ijder voor sooveell hem aangaet, hebben geleverdt eenen van gelijcken als desen jnhoudt ende deselve op ons wettboek beeedight. In meerder ende bondiger affirmatie hebben onse respective gewoone onderteekeningh onder desen gestelt, gelijck wij hooffden ende Raden van [de] Tarnataense ende Mackjanse armada ende die uijt den landtraedt van Amboyna ons als getuygen constitueeren, tot verificatie van welcke dese mede onderteekent.

Geschreven, gearresteerdt, bevreedight ende beslooten int cassteellAmboyna desen $22^{\text {en }}$ dagh der mane Rabou Awall ${ }^{1}$ jnt jaer des proopheets Mahumet $1038^{2}$; Stjlo Roma[no] den $22^{\mathrm{e}} 8 \mathrm{~b}^{\mathrm{r}} \mathrm{A}^{\circ} 1628$. Onderstont: Actum jnt cassteell Amboyna, datum ut supra; ende was hier ondergedruckt twee zegels in roode lacke en onderteekent als vollght.

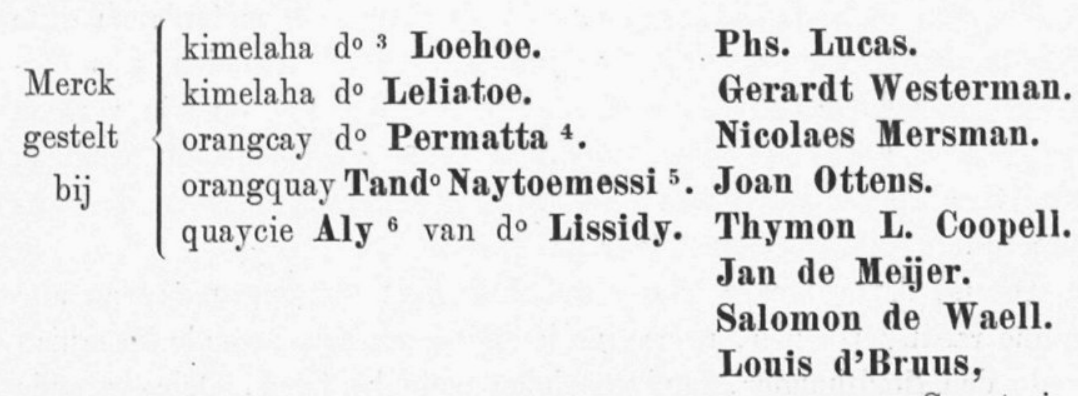

Secretaris.

\footnotetext{
1 Rabî al awwal. Deze maand begint voor het jaar 1038 met 29 October 1628 (Wüstenfeld, Tabellen, S. 42).

2 De Mohammedaansche en de Nederlandsche tijdrekening kloppen hier dus niet.

s Wat dit beteekent? Misschien afkorting voor dito, dat zoo dikwijls wordt gebruikt voor reeds genoemd. Bij Valentijn, bldz. 78, komt de onderteekening van den Kimelaha (van) Loehoe niet voor. Zie over hem Tiele-Heeres, Bouwstoffen, II, bldz. XLI.

4 Een dorp op de Noordkust van Ceram (Valentijn, Ambon, a, bldz. 54, v.)

${ }^{5}$ Schrijffout over Tanahitoemesen.

6 Hiermede wordt bedoeld kaitsjil Ali. (Vgl. Valentijn, bldz. 78).
} 
Manuell, $\mathrm{ko}^{\mathrm{k}}$ van Kilang.

Thome de Silva, ko ${ }^{k}$ van Soya.

Don Andrea, hoofft van Along. ${ }^{1}$

Gaspar de Freitas.

Don Pedro, hoofft v. Ottemorie. ${ }^{2}$

Anthonij da Cossta , mardijka. ${ }^{3}$

Anthonij Taweri, 't hoofft van Tavorij. ${ }^{4}$

Steven Tersera, 't hoofft van Poeta. ${ }^{5}$

\section{MOLUKKEN-AMBON.}

14 Augustus 1629. ${ }^{6}$

De staatkunde der Compagnie, hare handelspolitiek in de eerste plaats, had ook op Ternate ongenoegen gewekt. Wantrouwen werd gekweekt en groeide gestadig. Vooral onder sultan Modafar, die in $1610^{7}$ den troon had beklommen, waren de verhoudingen tusschen de Compagnie en Ternate niet steeds aangenaam (Tiele-Heeres, Bouwstoffen, II, bldz. I-VII). Modafars opvolger, Hamdja, sloot, daartoe genoopt door de doortastende houding van den Nederlandschen gouverneur der Molukken, Gijsbert. van Lodensteijn, in 1629 een nieuw contract met de O. I. C., vooral ter bevestiging der vroegere (Vgl. Bouwstoffen, II, bldz. XXXVI, v.).

Accoordt, gemaeckt door Gijsbert van Lodensteijn, ${ }^{8}$ gouvern ${ }^{\mathrm{r}}$ over de Moluccos, met den koninck van Ternaten.

Allsoo voor desen, ten tijde des overleedens konings Modafar, koninck van Ternate etc $^{\mathrm{a}}{ }^{9}{ }^{9}$ wiens ziele Godt genadigh zij, diverse quade breuken ende misverstanden in de oude voor desen gemaeckte bondige contracten sijn gekomen ende jngekropen, die noodigh,

1 Halong op Lei-Timor of Alang op Hitoe.

2 Hoetoemoerie, op Lei-Timor.

3 Valentijn: "Hoofd van Mardika."

- Tawiri op Lei-Timor.

${ }_{5}^{5}$ Poeteh of Wai Poeteh op Klein-Ceram? - Niet al deze inlandsche hoofden waren blijkbaar leden van den Landraad (Vgl. Heeres, Ambon in 1647, bldz. 551).

${ }^{6}$ Uit het Contractboek.

7 De Jonge, Opkomst, III, bldz. 107. Vgl. echter De Clereq, Ternate, bladz. 157 , noot 3 .

8 Deze was gouverneur der Molukken van 1629-1633 (Tiele-Heeres, Bouwstoffen, II, bldz. XXXVI).

9 Overleden den 16 Mei 1627. Hij werd opgevolgd door sultan Hamdja (Tiele-Heeres, Bouwstoffen, II, bldz. VII, XXXV).

7• Volgr. III. 
tot onderhoudinge van de allgemeijne russte, affbreuck onzer vijanden, wellstandt dezes rijcx ende vergenoeginge onzer ouder ${ }^{1}$ beschutheeren ende goede vrunden, de Hoogmogende $\mathrm{H}^{\mathrm{rn}}$ Staten Gener $^{1}$ der vrije Vereenighde Nederlandsche provintien, Zijne Princelijcke Ex ${ }^{\text {tie }}$, Fredrick Hendrick, prince van Orangie, grave van Nassou, etc ${ }^{\mathrm{a}}$ ende de $\mathrm{H}^{\text {rn }}$ Bewinthebberen der Vereenighde Oosstindische Comp ${ }^{\mathrm{e}}$, dienen geweerdt ende verbetert, om naer desen stricktelijk en zonder te gedoogen, wederomme eenige veranderinge geschiet, onderhouden te worden, alles onvermindert de geseijde voor desen gemaeckte oude contracten bij den voornoemden koninck Modafar ende den Tarnataensen Raedt mette $\mathrm{H}^{\text {ren }}$ admiraells Cornelis Matelieff ${ }^{2}$ en Frans Wittert ${ }^{3}$, mitsgd ${ }^{\mathrm{n}}$ den $\mathrm{H}^{\mathrm{re}}$ Gouvern $^{\mathrm{r}}$ Generaell Pieter Both ${ }^{*}$ gemaekt, die wij mits desen approberen ende begeeren tot 5 volcomen effect in alles sorteeren sullen; soo ist, dat wij, sulltan Adjall Amir Jll Mominina Hamsa Nassaron Hallaha ${ }^{6}$, coninck van Ternaten, etc ${ }^{\mathrm{a}}$, 't sampt die van onse Rade, opt goedtvinden ende advoij des heers Jan Pieterszoon Coen, Gouvern ${ }^{\mathrm{r}}$ Generael wegen den staedt der gemelte Vereenighde Nederlanden in dese Jndien, ende Gijstbert Lodensteijn, gouvern ${ }^{\mathrm{r}}$ over de Moluccos met sijnen bijhebbenden Raedt, gesamentlijck vergadert, hebben goedtgevonden, beslooten ende gearresteerdt 't naervolgende.

Eerstelijck belooven wij, coninck van Ternaten, den voor desen gepleegden trevis mette croone van Spangien en Tijdoor ${ }^{7}$ te verbreeken ende in geender manieren met haer eenige accoorden offte onderhandelinge, sonder consent, wille nogh voorweten van de geseyde $\mathrm{H}^{\mathrm{rn}}$ Staten Generaell, den prince van Orangien etc ${ }^{\mathrm{a}}$ offte haere gecommitteerde aen te gaen, maer deselve ter contrarie met

1 Valentijn, I, b (Molukse Zaaken), bldz. 262: „oude".

2 1607. $\mathrm{N}^{\circ} \mathrm{XXII}$.

3 1609. $\mathrm{N}^{\circ} \mathrm{XXVIII}$.

4 1613. $\mathrm{N}^{\circ} \mathrm{XLVI}$.

${ }^{5}$ Valentijn : „dat”.

"Valentijn : Minallahi Sjah".

7 Het was een der redenen van verwijdering tusschen Ternate en de O. I. C., dat genoemd rijk weinig lust betoonde den oorlog met Tidore en met de daarmede verbonden Spanjaarden voort te zetten, vooral niet, waar de Nederlanden, welke dien strijd gaarne zagen, toch aan Ternate weinig hulp boden. De krijg werd dan ook met weinig kracht vervolgd; een wapenstilstand met Spanje, nog door Modafar gesloten, werd door Hamdja erkend en deze sloot tevens in 1629, vóór de komst van Van Lodensteijn, ook met Tidore een wapenstilstand. Deze werd thans weder verbroken (Bouwstoffen, II, bldz. VII, XXXVI). 
alle onse maght beneffens haerluijden te beoorlogen ende vervolghen.

Dat alle de nagelen, soo hier in de Moluccos, op de Cust van Ceram, d'eijlanden van Amboijna ende andere plaetsen onder ons gebiedt, van niemandt ter werelld dan aen de coopluijden wegen de Vereenigde Nederlandtsche Oostjndische Compe gelevert sullen werden, schoon, suijver, droogh ende well geconditioneerdt, jegens vyfftien $\mathrm{R}^{\mathrm{a}}$ van aghten de baerh van $625 \stackrel{\leftrightarrow}{\mathrm{H}}$ Hollandts allhier, ende jn [de] quartieren van Amboijna ten prysse nu jonghts tusschen mijn broeder, kitchill Alij, admiraell van der zee, ende $\mathrm{d}^{\prime} \mathrm{H}^{\mathrm{r}}$ Philips Lucassen, gouvern ${ }^{\mathrm{r}}$ alldaer, beraemdt; ${ }^{1}$ op pene dat wie in contrarie bevonden werdt gedaen te hebben daer over op t hoogste zall gestrafft worden.

Sullen van gelijcken ook sorge dragen en aen alle onse ondersaten beveelen, de nagelen gepluct behoorlijck ${ }^{2}$ ende boomen well ${ }^{3}$ gehavent werden, zonder te hengen, ${ }^{4}$ deselve affgehouwen ${ }^{5}$ ende thuijnen jn plaetsen van dien, als voor desen meermaelen is geschiet, gemaeckt werden. ${ }^{6}$

Alle Christenen, van den vijandt overkomende offte [die] op de wegen bij ons werden ontmoet, 't zij dan Spangiaerden offte eenige andere natiën, sullen wij deselve dadelijck sonder haer eenighsints te beschadigen, maer veell eer alle hullpe ende vorderinge doen, aen de gecommitteerde van de geseijde Heeren Staeten overleveren, zonder ijets daervoor te eijschen. Mooren ende Heijdenen, geen van onse onderdanen zijpde, bij de ondersaten van de gemelte $\mathrm{H}^{\mathrm{n}}$ Staten comende om Christen te worden offte bij haer andersints te woonen, zullen t'zelve zonder tegenseggen van ijmandt vrijelijck mogen doen.

Mede allsoo dickwills geschiet, dat eenige onse onderdanen, soo vrijelijck $^{7}$ alls diensbarigh, van den vijandt gevangen als anders daer gekomen ende alldaer Christen gemaeckt zijnde, van daer weder weghvlughten, ende haer onder de gehoorsaemh ${ }^{t}$ van de gemelte $\mathrm{H}^{\mathrm{rn}}$ Staten offte d'onse begeven, sullen desulcke persoonen op haere aencomste ten overstaen van eenige van ons gecommitteerde ter eenre ende de gecommitteerde wegen den gouvern ${ }^{\mathrm{r}}$ in dese

\footnotetext{
1 Zie hiervóór, bldz. 220.

2Valentijn : "behoorlyk geplukt".

3 Valentijn : "behoorlyk".

4 Valentijn: "gehengen."

${ }^{5}$ Over de behandeling der nagelboomen, zie o. a. Encyclopaedie, III, 5. Het woord "havenen" hier in de vroegere beteekenis van goed behandelen.

${ }^{6}$ M. a. w. dat aan de nagelcultuur een eind wordt gemaakt.

7 Valentijn: „vrye".
} 
quartieren ter andere zijde affgevraegt werden, onder wellckers gehoorsaemh $^{t}$ zij haer willen begeven, welcke persoon 't selve allsoo affgevraeght ende haer onder d'eene offte d'ander subjectie hebbende begeven, zullen partijen naemaells niet vermogen, deselve persoonen, wederom van d'een tot ander vlughtende, te versteken, aghter te houden, noghte wegh te voeren, maer gehouden zijn, deselve datelijck, promptelijck ende zonder eenigh uijtstell ter handt stellen, dogh well verstaende, dat allsulcke persoonen, voor desen slaven offte slavinnen ende geen vrije luijden geweest zijnde, zullen deselve aen voor desen hare geweesene meesters betaelt worden, zoo haere ${ }^{1}$ de voorseijde gecommitteerden wegen de voorschreven $\mathrm{H}^{\mathrm{rn}}$ Staten begeeren, ijder tegens 60 Realen, de helfft jn contant ende de rest in kleeden; dogh vrije luijden zijnde, sall men daer niets vermogen voor te eyschen.

Ende van die ${ }^{2}$ van weder zijde differente persoonen, soo vrije als dienstbare, voor desen van deene tot ander overgeloopen, waervan de meeste all vertrocken ende vervoerdt zijn ende niet well mogelijck is, volldoeninge van wederzijden hierin te doen, sijn beijde partijen te vreeden, deselve te laten ter dier plaetse, daer jegenwoordigh zijn, zonder deselve naermaels wederomme te eijschen; maer ter contrarie eenige van deze persoonen weder van d'een tot d'ander overloopende, zullen parthijen gehouden zijn, deselve datelijck weder over te leveren, omme naer meriten ende goedtvinden van ijder van ons beijden gestrafft te worden, waeraen sigh d'een nogh d'ander niet en zall hebben aen te stooren.

Ende allsoo in den oorlogh dickwils geschiet, dat van wederzijden eenige bij den vijandt gevangen worden gekregen, sall men ju sulcken gevalle in generale verlossingen de oude voor desen gepleeghde gewoonte volgen, namentlijck eenige Hollanders en Ternatanen beij den vijandt ende eenige vijanden bij de ondersaten van de $\mathrm{H}^{\mathrm{rn}}$ Staten gevangen zijnde, sullen voor eerst de ondersaten van gemelte $\mathrm{H}^{\mathrm{rn}}$ Staten gelosst werden jegens allsulcke persoonen als in haere handen zijn; ende meerder van des vijandts volcks in handen sijn ende meerder van den vijand hebbende, sullen daer jegens de gevangen Ternatanen gelosst wierden, wellverstaende dat all sulcke geloste Ternatanen op hun aencomste in presentie des gouvern ${ }^{\mathrm{rs}}$ over dese quartieren offte zijne gecommitteerden ende d'onse sall affge-

1 Valentijn, bldz. 263: „zooals".

2 Valentijn: "naar dien”. 
vraeght worden, bij welcke van beijde partijen zij haer willen begeven ende haer begevende onder subjectie der voornoemde $\mathrm{H}^{\text {rn }}$ Staten, zullen sonder ijmandts tegenzeggen alldaer vermogen te blijven, zonder naermaells te vermogen, haer uijtte eenmaell aengenomen gehoorsaemh ${ }^{t}$ te ontrecken, maer gehouden zijn daer eeuwelijck onder te blijven, mits vrij sijnde van sulcken somme van penningen offte waerdije van die, alls tot haere verlossinge zall sijn verstreckt, daer sij ter contrarie gehouden sullen zijn, haer weder begevende onder de gehoorsaemheijt der croone van Ternaten, te betalen allsullcke somme van penningen offte waerdije van dien, als tot hare verlossinge zall zijn betaellt.

Van gelijcken allsoo jegenwoordigh de Hollandsche munte hier in treijn gebraght ende de Spaensche uijt geweerdt is, ende noodigh zomwijlen tot verlossinge der gevangene als anders het Spaensche geldt moet zijn gebruijckt, sullen de onderdanen der meergemelde $\mathrm{H}^{\mathrm{rn}}$ Staten gehouden zijn, ons daertoe met Spaensche munte voor ander in plaetse van dien te versien. ${ }^{1}$

Eenige misverstanden van wedersijden ontstaende, sullen partijen gehouden zijn, datelijck bij den anderen te komen ende deselve naer reght ende reeden ter neder te leggen ende te remideren.

Alle t'geene voorschreven staet, hebben wij, sulltan Hamsia, $\mathrm{ko}^{\mathrm{k}}$ van Ternaten et $^{\mathrm{a}}$ ende Gijsbert van Lodensteijn, gouvern ${ }^{\mathrm{r}}$ over de Moluccos, tsampt die van onsen Rade allhier, in de stad Maleije op 't eijlandt Ternaten vergadert, goedt gevonden, beslooten ende gearresteert tot weeringe van alle vordere onlust; belooven ende zweeren, t'sellve op ons wettboek ende eedt vast en onverbreekelijck te sullen onderhouden, alles sonder argh offte list. Jn oorconde der waerh $^{t}$ zijn hier van gemaeckt vier alleens luijdende, bij ons beijden onderteekent. Int jaer onses $\mathrm{H}^{\text {ren }}$ Jesus Christij 1629 den $14^{\mathrm{e}}$ dagh der maendt Augustij, jnt jaer Mahemet $1642^{2}$, den $22^{\mathrm{e}}$ dagh der maendt Haghij. ${ }^{2}$ Onder stondt: Actum jnt casteell Maleijen op Ternaten, datum utt supra. Was geteekent met eenige Arabische letteren ende Gijsbert van Lodensteijn. Hier onder gedruckt twee zegells in roode lacke. ${ }^{3}$

1 Vgl. nog Bouwstoffen, II, bldz. II.

2 Schrijffout natuurlijk voor 1042. Maar dan is de Mohammedaansche tijdrekening foutief. Immers volgens Wüstenfeld, Tabellen, valt 14 Augustus 1629 in de maand Dzoe'lhidjah 1038. Valentijn stelt het in het jaar 1042 , den 22 Rabi al-achir, wat nog minder goed klopt.

${ }^{3}$ Dit contract is den 1 Maart 1630 bekrachtigd door den G.G. Jacques Specx (Zie beneden, no XCVII). 


\section{KUST VAN KOROMANDEL.}

\section{November 16\%9. ${ }^{1}$}

Verschillende privileges voor de Nederlanders in Pulikat werden bij onderstaand kaul van den vorst van Carnatica verleend of bevestigd. Zij maakten de verhoudingen voor onzen directeur minder moeilijk, nu zij kwamen van de zijde des beheerschers van Carnatica zelf en niet van gouverneurs of andere ondergeschikte ambtenaren. Trouwens, geheel de stelling der onzen was op Pulikat sterker geworden. De Kusthandel werd steeds van grootere beteekenis, zoowel wat betreft de handelsartikelen voor Nederland (fijne lijnwaden, indigo enz.), als katoentjes voor den Maleischen Archipel (Vgl. Onuitgegeven missive van G.G. en $R$. aan Marten IJsbrantsz, 15 Juli 1628).

Translaet uijt caull des $\mathrm{ko}^{\mathrm{kx}}$ van Golconda ${ }^{2}$, Stij ${ }^{3}$ Rama, $A^{\circ} 1629$ in de maendt November op den dagh der nieuwe mane. ${ }^{4}$

Jck, koninck der coningen, den grootmaghtigen ende fictorieusen coninck Rama Deu Raija, geeue dese mijne caull neijropon aen den $\mathrm{Cap}^{\mathrm{n}}$ Moor der Hollanders, genaemt Marten, ${ }^{5}$ die met licentie van uwen prins in mijn plaets Paliacatta zijt gekomen om te handelen, waernaert zullt hebben te reguleren.

Aengaende de negotie hebbe ick den toll in ${ }^{6}$ van lossen als laden van alles t'geene met UE. schepen zoudt mogen brengen offte vervoeren om eere UE. gegeven ende vrije gelaten voor alltijts, zonder daervan ijets te sullen eijschen.

De sioncan ${ }^{7}$ van de negotie der coopluijden in Palliacatta alsmede dito int landt, ook de visie, sall wesen gelijck de maniere jn oude tijden.

1 Uit het Contractboek.

2 Is een ernstige schrijffout voor Carnatica, zooals de kopie in het Contractboek der Kamer Zeeland dan ook juist heeft.

${ }^{3}$ Moet natuurlijk zijn "Srij”. In de kopie in het Contractboek der Kamer Zeeland wordt de Vorst dan ook genoemd: "Srij Rama Deeva Raja".

4 Dat dit de 14 Nov. 1629 is geweest, blijkt uit de kopie van deze overeenkomst in het Contractboek der Kamer Zeeland.

5 Marten IJsbrantsz.

"Zeeland: "zoo". Hierbij staat in het Contractboek Zeeland nog de noot: ${ }_{n}$ Desen thol was 1618 of 1619 door Sumobel Ragoe, sijnde heer over Palliciatta en eenige omleggende landen, d'E. Compagnie reeds geschonken."

7 Zeeland: "joncan" = tollen. Onder dezen naam staan in het "contract", waarvan sprake is in de volgende noot, allerlei soort belastingen en heffingen bekend. 
De plaetse Palliacatta, 't zij off aen mijn behoude ende volck alldaer te gouverneren zende, off desellve verpaghte ${ }^{1}$ off aen eenige ragien ${ }^{2}$ offte ijmandt tot haer salaris ende onderhoudt geve, zall in aller manieren dit caull vasst ende van waerden blijven.

Geenige persoonen, tot visiadores toe, en sullen niet vermogen, van UE. ijets te eijschen off te trecken, daertoe ordre gegeven hebbe.

Eenige questie met den visiadoor offte jnwoonders deser plaets ontstaen zijnde, saeken van jmportantie, sullt UE. mij well weten laten; cleijne saeken mooght, sonder mij te doen weten, met den geenen, die alldaer gouverneren, consuleren ende in reeden affmaeken.

Hierop moght met alle coopluijden naer UE. wellgevallen vrijelijck handelen ende largo negotieren, op mijn woordt, waertoe dit mijn caull nieroupom hebbe gegeven, dat voor altoos mooght bewaren ende sonder eenigh aghterdencken op mijn vertrouwen ende blijfft met gesondtheijt.

\section{KUST VAN KOROMANDEL.}

\section{December 1629. ${ }^{3}$}

Terwijl in Pulicat, behoorende tot het rijk Carnatica, 's Compagnie's toestand in deze jaren zich gaandeweg verbeterde en bevestigd werd, waren in Mazulipatam (gelegen in het gebied der beheerschers van Golconda) de verhoudingen sedert 1619 (hiervóór, bladz. 154, v.) ongunstiger geworden (vgl. hiervóór, bldz. 194). De moeilijkheden schijnen te zijn ontstaan, doordat de Nederlanders de Moorsche kooplui in hunne vaart langs de Kust van Koromandel bemoeilijkten, maar ook tengevolge van knevelarijen der inlandsche autoriteiten. Vooral ook onze z.g. vrijburgers of vrije lieden, die op kaapvaart uitgingen tegen 's Comps vijanden, hadden terecht dan of ten onrechte een ongunstigen naam in die streken (Vgl. Onuitgegeven missive van Abraham van Uffelen, uit Masulipatam, aan Bewindhebbers, 23 April 1623). In November 1623 bereikten deze onaangenaamheden zulk een hoogte, dat de Nederlanders van de factorij te Mazulipatam, waaronder de toenmalige directeur der Kust

1 Dit gebeurde nog in datzelfde jaar, blijkens een in 't Contractboek achter dit contract opgenomen "Contract gemaeckt tusschen den Koninck ende Maleije overt renderen der stadt Palliacatta jnt jaer 1629 den $4^{\text {en }}$ Xber." ("aengaende de paghtinge van onse plaets Palliacatta"... "voor 3 jaeren"). In het Contractboek Zeeland wordt deze verpachting gesteld op 24 December. Bij "Malaije" staat daar nog aangeteekend: „Dit is een eernaem en zijn eijgentlijke is Astrappa Chittij (vgl. hiervóór bladz. 195) die A ${ }^{\circ} 1633$ of 1634 vervangen is door zijn broeder Chinnana Chittij, ook bijgenaamd Malaije, welke de tollen gaandeweg verhoogd heeft." Hij, evenals zijn broeder, behoorden tot de groote leveranciers in Pulicat van de Kustkleeden, zooals mij bleek uit archiefstukken (Vgl. ook Dagh-Register 1631-1634, bldz. 364).

2 Zeeland : „ragias", radja's = koning, vorst.

$s$ Uit het Contractboek. 
van Koromandel, Abraham van Uffelen, IJsbrantsz' voorganger, door den "Moorschen gouverneur" der stad werden gevangen genomen en naar de hoofdplaats des Rijks gevoerd. Deze aanslag was dan ook uitgegaan van 's Vorsten naaste omgeving en volgens de Nederlandsche autoriteiten "op gesochte actien". Van Uffelen en de zijnen werden, na "smadelijek getracteert" te zijn, tegen een losgeld, enz. ontslagen. Hij overleed 1 Febr. 1624 spoedig na zijn terugkeer te Mazulipatam, waar hij "wegen $t$ barbarisch ende onmenschelijck tractement, hem bij de Mooren in sijn gevanckenisse tot Golcondael aengedaen, geheel indispoost ende sieckelijck" was aangekomen. Maarten IJsbrantsz werd zijn opvolger (Zie hiervóór, bladz. 193). Maar met de vrijlating der Nederlanders was de verhouding niet in het reine gebracht. ${ }^{1}$ De autoriteiten te Batavia dachten er ernstig aan, ,in revengie van de tiranieque ende onlijdelijcke procedures bij den Moorschen Gouverneur tegen d'onze aldaer gepleecht... die van Masilipatan toffenderen ende t comptoir te lichten." Maar de Mooren waren hun vóór: in 't begin van 1625 werd ons dáár de ons vroeger ingeruimde loge ontnomen, terwijl de handel zeer werd bemoeilijkt. Toch bleven we daar een factorij aanhouden. De zaken bleven zóó sleepende en het denkbeeld om represailles te nemen werd voorloopig niet ten uitvoer gelegd, al meenden G.G. en Raden, dat het lichten der factorij en het aanslaan van "het Moorsche vaartuig" ons wel weder de noodige handelsvrijheid zou teruggeven, „want de Moorsche koopluijden, die ons den meesten overlast doen, zijn zij die de voornaamste kapitalen naar Mocha, Atjeh, Pegu en elders risqueeren." In 1628 werd tot het lichten van het kantoor te Mazulipatam besloten. Bij geheime instructie van 14 Juni 1628 werd aan IJsbrantsz gelast, dit tegen Jan. of Febr. 1629 te doen, verder "'t vaarwater te bezetten en de rijke geladen Moorsche schepen, op Mocha, Pegu, Arracan, Tanasserij, Atchijn en andere quaertieren handelende, in arrest te nemen". Ofschoon onze directeur eerst nog aarzelde, omdat hij meende, dat de schadeloosstelling, door de O. I. C. op die wijze te verkrijgen, niet voldoende zoude zijn, daar meest alle Moorsche schepen in de laatste tijden "disaster" hadden gehad, ging hij er in Februari 1629 toe over, daar ook de te Mazulipatam gevestigde Engelschen „met min of onmin" trachtten te verkrijgen, wat de Mooren daar hun schuldig waren. Hij bracht al ons volk en onze goederen van Mazulipatam, "Daetcheron, Palicol en omliggende plaetsen" 2 aan boord onzer schepen en de represailles begonnen. Al spoedig deden de Moorsche kooplui stappen tot toenadering en een voorloopige overeenkomst werd gesloten: onze tegenstanders zouden wat zij aan ons schuldig waren betalen, wij de reeds in beslag genomen schepen teruggeven, terwijl de handel vrij zoude worden. Den 8 November 1629 ging Jacob de Witt (met den Moorschen gouverneur van Mazulipatam) naar

1 Vgl. hierachter No XCIV.

2 Daetcheron, bij Valentijn Daatzerom, vond ik niet op Hunters atlas. Trouwens in Valentijns tijd was het plaatje reeds vervallen (Choromandel, bldz. 41, 42). Zijn haven was Coringo, thans Coringa (17 ${ }^{\circ}$ N.B.), ten Zuiden van Cocanada. Palakollu ligt ten N.O. van Mazulipatam bij de Godaweridelta. Hunter, Gazetteer, p. 254, vergist zich, als hij zegt, dat de Nederlanders hier eerst in 1652 een faetorij stichtten. 
Golconda, om daar aan het Hof de zaak der Nederlanders te bepleiten. Hij kwam 8 Maart 1630 te Mazulipatam terug. Vermoedelijk heeft hij toen onderstaanden ferman verkregen, evenals de daarop volgende (Vgl. Dagh-Register 1624-1629, bldz. 33, 34, 58, 190; onuitgegeven missives van Visnich aan G.G. \& R., 18 Jan. 1624, van IJsbrantsz aan Bewindhebbers, 28 April 1625, van G.G. \& R. aan IJsbrantsz, 26 Juli 1625 en aan Bewindhebbers, 8 Jan. en 3 Nov. 1628, 15 Dec. 1629; van Jan van Hassel uit Surat aan Coen, 22 Oct. 1628 en 27 Oct. 1629 ; onuitgegeven resolutie van G.G. \& R., 11 Maart 1628 en 2 Mei 1630).

Translaet uijt het firman offte mandaet, verleent door sullthan Abdula Godophia, ${ }^{1}$ kon $^{\mathrm{k}}$ van Golconda, aen den Cap $^{\mathrm{n}}$ der Holland ${ }^{\mathrm{rs}}$ jn Maslupatam residerende, wegen zijn negotie jnt landt van Elour ${ }^{2}$ verleendt.

Geve bij desen te kennen aen alle mijn gouverneurs ende ondersaten, soo hooge als lage, die jn mijne landen van Elour sijn gestelt, hoe den Capiteijn der Holland ${ }^{\text {rs }}$ in Masulipatnam residerende ons eenige malen geklaeght heefft, zijn negotie om tollen off sjonkannen bekommert ende gestut werdt, dat ons niet aengenaem te hooren is, weshalven [ik] UE. bij dit mijn firman mandere, sulx niet meer te pleegen, maer de Hollanders offte haere dienaren ongemolesteerdt nevens haere goederen in $U$ gouverno te laten gaen ende keeren, zonder haer eenighsints jnt affvorderen van thollen offte eenige aendre pretensien moeijelijck te vallen. Jngevalle [wij] vernemen, ghij geseijde Hollanders in eenige saeken hinderlijck sijt ende hun redenen geefft, schrifftelijck offt anders aen mijn te klagen, hebt mijne toorne ende straffe over $U$ te verwaghten. Daeromme sult haerlieden volgens dit mijn firman ende mandaet, t' welck ick hun verleent hebbe, vreedigh ende ongemolesteert laten negotieren.

Dit firman is van Sijn Maijt geprocureerdt door den seregheijll Mollamemet Tackij ${ }^{3}$, der Moorse maendt Rosiop ${ }^{4} \mathrm{~A}^{0} 1039$, zijnde $\mathrm{A}^{\circ}$ Christij 1629 den $11^{\text {en }}$ Xber.

${ }^{1}$ In den ferman, hierachter volgend als $\mathrm{N}^{\circ} \mathrm{XCV}$, wordt de naam iets beter gespeld: "Godopcha”. Bij Havart, Coromandel, II, bldz. 104, 210, wordt hij beter genoemd "Abdulla Kotbchia". Het is nl. Abdullah Kutab of Kutb Sjah, die in deze tijden (tot 1672) sultan was van Golconda (Vgl. Gribble, Deccan, I, p. 285 ; Hunter, Gazetteer, III, p. 513).

${ }^{2}$ Het tegenwoordige Ellore ten Noorden van Mazulipatam (Vgl. Hunter, Gazetteer, III, p. 209).

${ }^{3}$ "Den Sarchijl Mamet Tackij, den grootsten vijant van de Nederlandsche Compie" (Dagh-Register 1631-1634, bladz. 45).

4 Is dit de maand Radjab, dan komen de data weer niet overeen: immers deze maand van het jaar 1039 begint met 14 Februari 1630. De Nederlandsche dagteekening valt in de maand Rabi-al-achir 1039. 
Nota: van gelijcken jnhoudt hebben nogh 3 firmans, namentlijck wegen de landen Condapilli, ${ }^{1}$ Condawierre ${ }^{2}$ ende Ragimandre ${ }^{3}$ zijnde met voorschreven van Elour de grootste gouvernos vant Gollcondase rijk, waerinne d'E. Compe haeren handell ten principaellsteu js drijvende ende door welcke hun geprocureerde goederen meest moeten passeeren. ${ }^{4}$

\section{KUST VAN KOROMANDEL.}

\section{Februari 1630. 5}

Deze ferman is door De Witt zonder twijfel op zijn reis naar Golconda verkregen.

Firman des koninghs van Golleonda, $\mathrm{A}^{0} 1629^{6}$ met den opperkoopman Jacob de Witt bekomen.

Firman des Konings, geschreven aen de Cap ${ }^{t}$ der Holland ${ }^{\text {rs }}$.

UE. hebt mij met een van U volck eenen brieff geschreven, waerbij gesien, [dat] den gouvern ${ }^{\mathrm{r}}$ UE. heefft affgenomen $1600^{\text {? }}$ pagoden in verscheijde reijsen, waerover UE. t' hert heefft gebrooken ende geresolveerdt, de bandaer te verlaten. Jn 6 jaren begeere [ik, dat gij] de $1600^{7}$ pagoden sult jnhouden totter tijt UE. betalinge hebt. In de 5 jaeren is UE. op 1000 pagoden naer volldaen, die jnt seste jaer sult jnnehouden ende de verdere 2000 pagoden aen

${ }^{1}$ Kondapalli, ten N.W. van Mazulipatam (Vgl. Hunter, Gazetteer, V, p. 435).

2 Kondavir, ten W. van Mazulipatam.

${ }^{3}$ Vermoedelijk Rajamahendri, ten N.O. van Ellore (Vgl. Hunter, Gazetteer, VII, p. 495).

4 De O.I. C. verkreeg dus hierbij tolvrijheid in ongeveer geheel de tegenwoordige Kistna- en Godaweri-districten.

${ }^{5}$ Uit het Contractboek. - De ferman, voorkomende bij Havart, Cormandel, II, bldz. 103, 105, foutief gedateerd 1631, is blijkbaar eene andere lezing van onderstaand document.

${ }^{6}$ Waarschijnlijk een foutief jaartal. In het Contractboek Zeeland komt voor een extract van dezen ferman: hij was "geschreven in de mane Redjeb 1039 of $\mathrm{A}^{\circ} 1628$ ". Dit laatste jaartal is stellig onjuist, want De Witt is eerst in 1629 naar Golconda vertrokken. Maar Radjab 1039 komt overeen met Februari-Maart 1630.

7 Schrijftout voor: 16000 . Volgens de overeenkomst van 24 Juli 1619 (hiervóór, bldz. 154) moesten de Nederlanders 3000 pagoden 's jaars als vaste som voor in- en uitgaande rechten betalen. Ofschoon deze reeds vooruit betaald waren voor 5 jaar, waren zij te Mazulipatam opnieuw geeischt(Vgl. Havart, Cormandel, II, bldz. 103). 
den Gouvern ${ }^{\mathrm{r}}$ jntrageeren ${ }^{1}$ ende jnt duwaus boek ${ }^{2}$ gestelt sullen worden. Voor en all eer de 16000 pagodeu door UE. sijn ingehouden, heefft jemandt ${ }^{3}$ op UE. ijets te pretenderen. De ses jaeren gepasseerdt zijude, zult t' zevenste jaer volgens voorige cosstuijme weder 3000 pagoden betalen, waer op UE. jn ruste mooght sitten, zonder van ijmandt getolleerdt (sic) te worden. Buijten dit, t'zij wat coopluijden, t'zij Mooren, s' Jentijven off wie t soude mogen zijn, moogen koopen ende verkoopen, zonder van ijmandt daerin verhindert te werden en wadt goudt offte zillver met UE. schepen brengen, zijn de coopluijden niet gehouden, yets aen den saraff ${ }^{4}$ daervan te betalen. Jaerlycx wensch [ik], UE. veell scheepen bekomt, op dat de poorte der bandaer magh door UE. verbetert worden. Ter zijde stondt: sulltan Abdula Goudophia.

\section{KUST VAN KOROMANDEL.}

\section{$1630 ?^{5}$}

Deze ferman is eveneens een gevolg der zending van De Witt. Toen hij naar Golconda ging, werd hij vergezeld door den Moorschen gouverneur van Mazulipatam. Deze werd, blijkens onderstaand staatsstuk, vervangen door "Miersa Rosbaham" of "Mierosbahijn", die den $12 \mathrm{Juli}$ 1631 nog gouverneur was en "onzen goeden vrindt" (Vgl. Dagh-Register 1631-1634, bldz. 44, 45). Onderstaande ferman moet dus dagteekenen van geruimen tijd vóór dezen datum.

Firman des koninghs van Gollconda, beneffens ${ }^{6}$ den gouvern $^{\mathrm{r}}$ Miersa Rosbaham aen $\mathrm{d}^{\prime} \mathrm{H}^{\mathrm{r}}$ gouvern $^{\mathrm{r}}$ Marten Ysbrantszoon gesonden.

Jck, sulltan Abdola Godap Cha, $\mathrm{ko}^{\mathrm{k}}$ van Hydarabast, ${ }^{7}$ zende dit myn firman aen den $\operatorname{Cap}^{t}$ Moor van de Hollanders tot Masu-

1 Portugeesch : entregar $=$ overhandigen.

2 Diwan, dewaun. Het boek der in- en uitgaande rechten, de registers van de staats-financiën of iets dergelijks, moet hier met deze uitdrukking worden bedoeld (Vgl. Hobson-Jobson, p. 238ff).

$s$ Natuurlijk een schrijffout voor: niemand.

4 Blijkbaar op het wisselkantoor (Vgl. Havart, Cormandel, II, bldz. 105).

5 Uit het Contractboek.

"Hier zal dit woord moeten worden opgevat in den zin van "tegelijk met".

7 Haidarabad, ten Oosten van Golconda. Nog slechts kort geleden was door een der voorgangers van Abdullah Kutb Sjah zijn residentie van Golconda verlegd naar Haidarabad, in de onmiddellijke nabijheid (Hunter, Gazetteer, Ш, p. 512; Gribble, Deccan, I, p. 269; Havart, Cormandel, I, bldz. 203, 204). 
lipatnam. - Jck hebbe UE. voor desen een firman gesonden, waerop verstaen, UE. met $d^{0}$ niet gecontenteerdt en was. Jck zij naerder van UE. saeken onderreght, dat UE. over quade tractement van UE. gouverneurs, mede over quade betalinghe van UE. dievadores ${ }^{1}$ de plaets van Masulipatnam hebt verlaten. Jck hebbe 't gouverno $\mathrm{d}^{0}$ gouvern $^{\mathrm{r}}$, die UE. gediscontenteerdt heefft, van Masulipatnam ontnomen ende in $d^{\text {os }}$ plaets een ander gestelt, die UE. in aldermanieren soeken soude te contenteeren, UE. schullden te jnnen offte UE. schulldenaers jntrageeren. Naerder is mijn ondereght, soo [ik] geen persoon van qualiteijt offte groote discretie bij UE. sondt, UE. in geender manieren en zoudt laten contenteeren. Ick hebbe bij experientie bevonden, dat desen mijnen gouvern ${ }^{\mathrm{r}}$ Miersa Rosbaham een man van goede discretie ende een getrouw dienaer van mij is; uijt dier oorsake goedt gevonden $d^{0}$ UE. toe te senden ende hebbe $d^{\circ}$ op sijn vertreck belast als vooren, waer dat UE. eenige schullden hadden uijtstaende, dat de sellffde zoude zijn [zien?] te jnnen offte de schulldenaers UE. soude jntrageeren, t' zij in wat plaets in mijn landt dat die soude mogen uijtstaende sijn; meede tot wadt plaetse UE. sijn negotie dryfft, dat UE. op geenige plaetsen eenigh gewellt offte force sall aengedaen worden. Jck hebbe UE. voor desen een firman offte caull gesonden, waertegens geenige gouvern $^{\mathrm{r}}$ jn mijn gouverno haer sullen mogen tegen stellen. Jck hebbe ook aen den Gouvern ${ }^{\mathrm{r}}$ belast, als UE. de gewoonlijcke tollen die jaerlijcx betaelt, UE. in UE. negotie int minsten niet sullen hinderlijck zijn. Jck versoeke, dat UE. haer wederom tot Masulipatnam ter neder stelt ende maeckt dat de stadt magh well varen, ende de negotie haer voortganck hebben. UE. weest mede de schepen die van Masulipatnam vertrecken, in aller maniere behulppsaem: mijn sall daer sonderlinge vrundschap aen schieden. Jck soude mede geern een schip naer Ormus zenden: UE. gelieve ons tot $d^{0}$ voyagie de behullpsame handt te bieden. Tot een teeken van vriendschap hebbe aen UE. 4 diverse tassarijven ${ }^{2}$ gesonden. UE. geliefft derhallveu onse tassarijven niet te verwerpen, maer op dit [van] ons gesonden caull wederom tot Masulipatnam aen landt komen ende UE. negotie naor begeeren drijven. Zoo der op UE. hardt nogh ijets moghte schuijlen, waerinne UE. niet contenteerdt is, geliefft het selve met den eersten aen mijn te schrijven. Sullen jnt geene UE. reght heefft,

1 Afgeleid van diwan, dewaun (bldz. 235, noot 2)?

2 Tashrif, hier in de beteekenis van eeregeschenk, eerekleed (HobsonJobson, p. 686). 
UE. volcomen contentement doen. Dat UE. wederomme aen landt komt ende helpt Maslupatam te reght, zall UE. de groote eere werden toegeschreven. Hiermede zijt naer onse groete Godt bevolende ende verhoopen, UE. hem sall laten geseggen.

\section{FORMOSA-CHINA.}

\section{Februari 1630. ${ }^{1}$}

Met Iquan ${ }^{2} \mathrm{kwam}$ de Compagnie, althans uiterlijk, op goeden voet. $Z_{i j}$ verleende hem zelfs hulp tegen zijne vijanden (vgl. beneden) en Iquan belooft, bij het onderstaand verdrag, haar geene beletselen in den weg te leggen, enz. De vijanden, waarmede Iquan na zijne indiensttreding bij de Chineesche regeering had te strijden, waren vroegere ondergeschikten van hem: een zijner "kapiteins, Quitsicq genaamd", was nl. van hem afgevalien met een groot aantal der zeeroovers en veel vaartuigen. Iquan verzocht tegen hem onze hulp, waartoe wij te meer genegen waren, wijl de zeeroovers den Formosaanschen handel belemmerden. Ook Quitsicq trachtte, ons in zijn belang te winnen en belooft, de vaart der Chineezen op Formosa niet te belemmeren, maar wil ons den vrijen handel op China's kusten niet inwilligen. Hij versloeg Iquans macht in 1629 en verovert Amoy, maar met behulp der O. I. C. wordt hij vandaar verdreven en zijne macht vernietigd, terwijl Iquan weer in het bezit van Amoy wordt hersteld (Onuitgegeven missives aan Bewindhebbers van Coen, 18 Maart 1629; van G.G. \& R., 15 Dec. 1629; van A. van Diemen, 5 Juni 1631).

Accoordt getroffen tusschen d' $\mathrm{H}^{\mathrm{r}}$ Hans Putmans, gouvern $^{\mathrm{r}}{ }^{3}$ over des Comps fordt, schepen ende volckeren in Taijovan, de Custe van Cina ende aenkleven van dien wegens de generaele Oosstjndische Compe ter eenre ende de Jncquan, groot mandorijn van Aijmoịj ende admirael generael van de Chineese zee, ter andere zijde.

Allsoo de Hollanders mij met hare schepen, goedt ende bloedt naer uijtterste kraght ende vermogen jegens den roover Quitsick hebben geassisteerdt, den zelven t'eenemaell vernielt, verdreven

1 Uit het Contractboek.

2 Zie hiervóór, bldz. 215.

3 Hij was Nuyts als zoodanig opgevolgd in 1629 (Vgl. hiervóór, bldz. 217, noot 2). Putmans was, na zijne aankomst op Formosa (21 Juni) al spoedig (December 1629) Iquan te hulp gekomen (Onuitgegeven missires van G.G. \& $R$. aan Bewindhebbers, 15 Dec. 1629; van Van Diemen aan Bewindhebbers, 5 Juni 1631). 
ende $t^{\prime}$ ondergebraght ${ }^{1}$ ende mij weder in vorige possessie binnen Aymoy gestelt, onder reserve ick de hier naevolgende conditien ende poincten, soo veell mij deselve raeken, in recompense ende danckbaerh $^{t}$ zoude aen de Generale Oosstjndische Comp ${ }^{\mathrm{e}}$ presenteeren, soo hebbe, om $t$ allen tijden te bewijsen, ick aen de gemelte Comp ${ }^{\mathrm{e}}$ die te presteeren gehouden ben, hier van schrifftelijcke acte aen d' $\mathrm{H}^{\mathrm{r}}$ gouvern $^{\mathrm{r}}$ Putmans wegens gemelte Generale Comp ${ }^{\mathrm{e}}$ verleent, ten eijnde t' geene hier inne gementioneerdt staet bij een jgelijck van ons beijden, voor soo veell ijder daervan is rakende, allsoo onverbrekelijck t'allen tijden geobserveerdt ende naergecomen werde.

Dat ick, Jquan, de Generale Oosstjndische Compe de handell zall laten genieten, zoo in de revier Chinceo, ${ }^{2}$ zoo jn Taijoan, soo lange ick leeve, ende versorgen dat sulx ook bij mijnen erffgenaem, successeur int gouverno, naer mijn affsterven geobserveerdt ende naergekomen werde;

dat ick, uit gemelt faveur van de gemelte Compe aen den Combon sall schrijven, dat haer den langen belooffden liberen handell, soo in Hockseo, ${ }^{3}$ Chincheo ende andere plaetsen van ${ }^{4}$ opene ende laete exerceren voor alltijt;

dat ick datelijck gemelten gouvern ${ }^{r}$ Putmans een goede grote jonk sall beschicken ende, soo haest Tousaijlacq ${ }^{5}$ van sijn exploijct zall sijn geretourneerdt, nogh drie a vier van de besste;

dat ick tot soulagiment van 't verongeluckte jaght Slooten ${ }^{6}$ zall geeven $2000 \mathrm{R}^{\mathrm{a}}$ van $8^{\text {ten }}$ ende voorts telcken ${ }^{7}$ een weijnigh, tot dat ick de geleende ${ }^{8}$ schade van 't voornoemde jaght ten vollen zall gerepareerdt hebben.

Tegens welcke voorschreven conditie jck, Hans Putmans, wegens de gem $^{t}$ Comp $^{e}$ beloove, den voornoemde Iquan met schepen ende

${ }^{1}$ Hij werd aan den combon van Hokkiën gezonden, "waar hij een wreeden dood erlangd heeft."

2 De rivier van Amoy.

3 Vgl. hiervóór, bldz. 196.

4 Hier is blijkbaar iets uitgevallen.

" "De roover Touseylack", een der vroegere ondergeschikten van Iquan, die eerst Quitsicq's partij had gehouden, maar later met Iquan en Putmans zich had vereenigd tegen dezen (Onuitgegeven missive van Van Diemen aan Bewindhebbers, 5 Juni 1631). Op welk „exploijet" hij was uitgezonden, heb ik niet gezien.

${ }^{6}$ Vgl. Dagh-register 1631-1634, bldz. 8. Het sehip was verongelukt bij het krijgsbedrijf tegen Quitsick.

7 Hier is blijkbaar iets uitgevallen.

$s$ Geleden? 
volck, zoo tot versekeringe zijnes staets als devalisatie der roovers ter plaetse, daer 't de saeke zoude mogen vereijschen, zoo veell mogelijck sall assisteren en hellpen.

Actum $13^{\mathrm{e}}$ Februarij 1630 jnt jaght Texell, leggende ter rheerle voor Aymoy. ${ }^{1}$

\section{MOLUKKEN-AMBON.}

\section{Maart 1630. 2}

Het contract van 14 Augustus $1629^{3}$ was gesloten onder nadere goedkeuring van den gouverneur-generaal Coen. De onderstaande ratificatie draagt de onderteekening van diens opvolger Specx.

Acte van approbatie ende vernieuwen der contracten in Molucco.

Jaecques Specx, gouvern ${ }^{\mathrm{r}}$ generael wegen de doorlughtige Hoge Mogende $\mathrm{H}^{\text {ren }}$ Staten Gener ${ }^{1}$ der Vereenighde Nederlanden, Zijn Princelijcke Ex ${ }^{\text {tie }}$ Fredrick Hend ${ }^{\mathrm{k}}$, bij der gratie Godts prince van Orangie, grave van Nassouw , etc ${ }^{\mathrm{a}}$, mitsga ${ }^{\mathrm{drs}} \mathrm{d}^{\prime} \mathrm{E} . \mathrm{H}^{\mathrm{rn}}$ bewinthebbereren van de Generaele Vereenighde Geoctroijeerde Nederlandtsche Comp ${ }^{e}$ in Jndien, allen dengeenen, die deesen sullen zien offte hooren leesen, saluijt, doen te weten.

Allsoo t' zeedert eenige jaeren herwaerdts tusschen $\mathrm{d}^{\prime} \mathrm{H}^{\mathrm{rn}}$ gouvern ${ }^{\mathrm{rs}}$ wegen d'Hoge Mogende $\mathrm{H}^{\text {rn }}$ Staten Gener ${ }^{\mathrm{l}}$ der Vereenighde Nederlanden, Zijne Princelijcke Ex ${ }^{\text {tie }}$ Frederick Hend ${ }^{\mathrm{k}}$, bij der gracie Goodts prince van Orangien, ende de Bewinthebberen der Vereenighde geoctroijeerde Oosstjndische Comp ${ }^{\mathrm{e}}$, in de Moluccos als

1 Ten opzichte van den handel verklaarde Iquan nog, dat hij niet zou kunnen beletten, dat Chineesche jonken werden uitgerust naar Manila, Patani, Siam, Kambodja, Kelang (of Kelang-Tamsui, op Formosa's Noordkust, waar de Spanjaarden zich, in 1626?, hadden gevestigd). De tollen, welke volgens Iquan 's jaars een 180.000 tael bedroegen, konden niet worden gemist, waar "het kapitaal van de Comp. niet bestant was, $\frac{1}{10}$ van den uitvoer te verzwelgen" (Onuitgegeven missives aan Bewindhebbers, van G.G. \& R., 13 December 1626, van Van Diemen, 5 Juni 1631; onuitgegeven Descriptie bü Dav. Pessaert en Vinc. Romeijn, 10 Sept. 1627).

Over Iquan's latere houding zie Dagh-Register 1631-1634, bladz. 8 .

2 Uit het Contractboek.

3 Hiervóór, No XCI. 
Amboijna ter eenre ende de stadthouders als opperhooffden van de omliggende eijlanden ende dorpen van Amboijna ende Ceram, weegen de Konincklijcke Maijt van Ternaten in de gemelte quartieren ende de Moluccos ter andere zijde verscheijde differenten ende missverstanden ontstaen ende bij verloop van tijt soodanigh toegenomen waren, dat ons ende Zijne Maijs onderdanen daerdoor niet alleenlijck een geruijmen tijt in groodt misvertrouwen ende oneenigh ${ }^{t}$ hebben geleefft, maer dat ook geschapen stonden, tot ons ende Zijne Maij ${ }^{\text {ts }}$ leetweesen, de saecke van ${ }^{1}$ termen van hostiliteijt te vervallen, welcke voorschreven misverstanden, differentien ende oneenigheden nogh bij de gemelte onse gouvern ${ }^{\text {rs }}$, nogh bij Sijne Maijt offte Zijne Maijts stadthouders in de gemelte quartieren van Amboijna ende Ceram in eenige jaeren niet hebben connen geassopieerdt offte te nedergeleijt worden, onaengesien datter verscheijden conferentien ende onderhandelingen ${ }^{2}$ communicatien wegen de gemelte respective gouvern ${ }^{\text {rs }}$ ende stadthouders tot dempinge van de voorschreven oneenigheden, soo in Amboijna als Ternaten, hier over gehouden geweesst sijn, tot dat eijndelijck de $\mathrm{H}^{\mathrm{r}}$ Gijsberdt van Lodensteijn, onse jegenwoordige gouvern ${ }^{\mathrm{r}}$ in Ternate ende zijne raedt, mitsgd ${ }^{\mathrm{s}}$ den sulltan Adiall Amerill Momenin Hamsia Nassaron Halla Scha, Koninck in Ternata, geassisteerdt met den gantschen Ternataensen Raedt, mitsgdrs $d^{\prime} \mathrm{H}^{\mathrm{r}}$ Philip Lucas, onsen jegenwoordigen gouvern ${ }^{\mathrm{r}}$ in de quartieren van Amboijna, geassisteerdt met sijnen rade ende de naturele leden uijt den landtraedt alldaer, mitsgd $^{\text {rs }}$ quitchill Alij, representeerende in dien tijden Zijne Maij ${ }^{t}$ persoon alldaer, geassisteerdt met Sijn Maij ${ }^{\text {ts }}$ stadthouders Leliatoe, de landtvooghden van Loehoe, Combello, Lissidij ende d'hooffden van de omleggende eijlanden ende dorpen, Olisiva ende Olijlijma, op onse ende Zijne Maijts approbatie alle misverstanden ende questien ter nedergeleght ende met minnelijckh ${ }^{t}$ met den anderen overeen gecomen, veraccordeert ende bevreedight sijn, onder allsulcken conditie ende artijkelen als de origineele contracten bij de gemelte respective gouvern ${ }^{\mathrm{rs}}$ ende Zijne Maij ${ }^{\text {ts }}$ van Ternate quitchill Alij, jn den jare $1629^{3}$ gemaeckt ende resiproquelijck geteekent, breder is blijkende.

Soo ist, dat wij gesien, geventileerdt ${ }^{4}$ ende overwoogen hebbende

1 Schrijffout voor „in" (Vgl. Valentijn, I, b, Molukse Zaaken, bldz. 265).

2 Valentijn : "onderlinge".

${ }^{3}$ En 1628. Zie hiervóór, No XC en XCI.

4 Behandeld. 
de gemelte contracten ende conditien, daerinne gestipuleerdt, sulx als ons deselve bij onse gemelte respective gouvern ${ }^{\text {rs }}$ [van] Amboijna ende de Moluccos toegesonden zijn, deselve met advijs van onsen rade naer haere forme ende jnhouden gelaudeert, geapprobeerdt ende guratificeerdt hebben, gelijck wij die lauderen ende geratificeerdt mits desen; belasten ende beveelen derhallven alle gouvern ${ }^{\text {rs }}$, presidenten, command $^{\text {rs }}$ ende opperhooffden die van wegen de Hoge Mogende $\mathrm{H}^{\text {ren }}$ Staten Gener ${ }^{1}$ der Vereenighde Nederlanden, Zijne Princelijcke Ex tie ende Bewinthebberen van de Geoctroijeerde Oosstindische Compe uijt onsen name jegenwoordigh in de quartieren van Amboijna ende Ternate gouverneren ende commanderen, de gemelte contracten op alle plaetsen, onder haer gesagh ende gehoorsaemh $^{t}$ sorterende, in alle haer leden volcomentlijck ende religeuslijck t' observeren ende te doen observeren, mitsgdrs tegen de contraventeurs van dien op't rigoreuste te procederen, op pene van te vervallen in de hooghste straffe, allsoo wij sulx tot augmentatie van de onderlinge vrundschap ende vermeerderinge van de mutuele commertie, ten bessten van den Ternataenschen ende onsen staedt, mitsg $^{\text {rs }}$ aff breuck van onse allgemeijne vijanden, allsoo bevinden te behooren, $\operatorname{etc}^{\mathrm{a}}{ }^{1}$.

Alldus gedaen jnt Casteell Batavia desen eersten Martij A ${ }^{\circ} 1630$. Onderstondt Jacques Specx; ende ter zijde: ter ordonnantie van $\mathrm{d}^{ } \mathrm{E} \mathrm{d}^{\mathrm{e}} \mathrm{H}^{\mathrm{r}}$ gouvern ${ }^{\mathrm{r}}$ gener ${ }^{\mathrm{l}}$ onderteekent $\mathrm{D}^{\mathrm{r}}$ van der Lee ${ }^{2}$. Opgedruckt met het zeegell van de Compe.

\section{KUST VAN KOROMANDEL.}

\section{Angustus 1630. ${ }^{3}$}

Van dezen zelfden dag dateert een ander kaul door denzelfden gouverneur gegeven aan eenige met name genoemde inlandsche kooplieden, waarbij hun wordt medegedeeld, dat aan de Nederlanders onderstaand kaul was verleend. Het is niet noodig, dit stuk hier nog op te nemen; maar

1 Dit „etc." niet in de lezingen bij Valentijn, I, b, bldz. 265, en II, b, bladz. 82 .

2 Dr. (Dirk) Van der Lee was secretaris der Hooge Regeering (Valentijn, IV, Groot Djava, bldz. 373).

${ }^{3}$ Uit het Contractboek.

7• Volgr. III. 
wèl, hier mede te deelen, dat daarin wordt gezegd, dat door hem aan de onzen daarbij vergunning was gegeven, om vrijelijek in alle plaetsen onder (zijn) gouverno sorterende, te weten Montipille, Ragourij, Pinnangansan, Neijnepille, Cottapatta, als alle plaatsen onder 't gebiedt van Petapoelij, te mogen negotieren". De toevoeging : "'t gebiedt van Petapoelij" geeft tegelijk een aanwijzing omtrent andere plaatsen. Petapoeli is hetzelfde als Nizampatam (toen tot Golconda behoorende) ten Z.O. van Mazulipatam, aan de Kistna-delta (Valentijn, V, 1, Choromandel, a, bldz. 30). Vermoedelijk is het dus de gouverneur van Petapoeli, welke den vergunningsbrief heeft verleend. Reeds sedert 1606 waren de onzen met Petapoeli in aanraking gekomen (Zie hiervóór, bldz. 100; De Jonge, Opkomst, III, bladz. 41, 77, v., 340, 399).

Caull door Hasaratta Ohane ${ }^{1}$ Susia Jetha etc ${ }^{\mathrm{a}}$ aen de Nederlanders verleent, 21 Augustij A ${ }^{\circ} 1630$.

Hasaretto Ohane ' Sucia Jetha Vajaretta d'Asstagaha Ohane 1 Adjem Soro Mahamede Ohane ${ }^{1}$,

Aen den Capiteijn Moor der Holland ${ }^{\mathrm{rs}}$ hebbe gegeven dese mijne caull. Jn mijn gouvernemendt Alldij de Oupelon, 2 Montipillij, , 3 Rogouron, 4 Pinangansen, ${ }^{5}$ Leijnepilli. ${ }^{6}$ Cottapoetta ${ }^{7}$ offte eenige andere plaetseu, daer UE. zoud mogen negotieren, van alle de goederen die UE. zoudt mogen disbarqueren offte van de goederen die allhier zoudt mogen koopen ende jnbarcqueren, ${ }^{8}$ zult UE. geen tollen, te weten van de 'sjoncans, melavisall, egomitij, digomitij offte eenige anders sjoncans betalen, waer op UE. mij mooght vertrouwen ende UE. negctie vrijelijck ende zonder becommering drijven. Zoo UE. scheepen eenige goederen in Carjera ${ }^{9}$ komen te lossen,

1 Chane?

${ }^{2}$ Kan ik niet terechtbrengen. Wel wijs ik er op, dat de rivier de Paler ten Zuiden der Kistna bij Valentijn heet "Opeleer" (Kaart van Choromandel).

${ }^{3}$ Motupalli ten Z.W. van Nizampatam?

4 Kan ik niet terechtbrengen.

5 "Pedde Godsjan" (ten W. van Petapoeli) op Valentijn's kaart? ?

"Schrijffout voor "Neijnepille" = Naimpilli bij Valentijn (Vgl. Dagh-Register 1631-1634, bldz. 362).

7 Kottapatnam (ca. $15^{\circ} 27^{\prime}$ N.B.) = Aloer (Hunter, Gasetteer, I, p. 153).

8 De inlandsche kooplieden, van wie in het bovengenoemde kaul sprake is, moesten wel degelijk betalen in- en uitgaande rechten, behalve voor goud en zilver.

${ }^{9}$ Op Valentijn's kaart van Koromandel vindt men een Carrera aan de mondin der Opeleer (tgw. Paler-rivier) en een Karera, meer landwaarts aan de Naneer (Manner rivier?). Vermoedelijk zal de eerstgenoemde plaats hier wel bedoeld zijn, daar zij aan de kust ligt. - De O. I. C. kreeg hierbij dus tolvrijhreid in het Zuidelijk deel van het Kistna-, en in het Noordelijk deel van het Nellore-district. 
sall UE. dit caull mede tot segoura ${ }^{1}$, gelijck als de voorschreven plaetsen, dienen. Onderstaet mijn chiap.

\section{FORMOSA-CHINA.}

\section{December 1630. ${ }^{2}$}

De moeilijkheden in de verhoudingen met China begonnen al spoedig weder na de gebeurtenissen van December 1629 en de eerste weken van 1630 (zie hiervóór, No XCVI). Reeds in October 1630 beginnen Putman's berichten ongunstig te worden. Touseijlacq maakt zich meester van de rivier van Amoy, trachtende de plaats van Iquan in te nemen. Hij laat eerst wel den handel tusschen Formosa en Amoy ongemolesteerd; maar vervolgens, vermoedende (en niet ten onrechte), dat de Nederlanders met Iquan tegen hem samenspannen, maakt hij zich meester van een Nederlandsch jacht en 5 jonken en van 69 gevangenen. De onderhandelingen hebben eerst geen resultaat. Maar Iquan wordt verplaatst en Touseijlacq wordt „ingeroepen om in Aymoy te resideeren". Hem wordt inderdaad het gebied "op de rivier van Chincheu" toevertrouwd en met den titel "Songia" wordt hij "absoluut mandorijn van Aymoy". Thans is deze bereid, te onderhandelen met Putmans en onderstaande overeenkomst, minder voordeelig voor de O.I.C. als die met Iquan, komt tot stand (Onuitgegeven missive van Van Diemen aan Bewindhebbers, 5 Juni 1631).

Accoordt tusschen de gecom ${ }^{\text {den }}$ van d'E. $\mathrm{H}^{\mathrm{r}}$. Gouvern ${ }^{\mathrm{r}}$ Puttmans ende Raedt jn Taịjovan wegens de Generale Oostjndische Comp ${ }^{e}$ ter eenre ende Songia, groot mandorijn van Aịmmoịj ende admirael ter zee, ter andere zijde, getroffen ende ouverbrekelijck aengegaen.

Jn den eersten dat geen Hollanders schepen in de reviere Chincheo, om den handell offte ijets anders te versoeken, zoo lange hun denselven sonder eenigh onderscheịt van persoonen in Taijoan als de reviere voorn ${ }^{t}$ met jonken te excerceren vergundt werdt, sonder licentie van Songia sullen verschijnen. ${ }^{3}$

Ten tweede dat soo haest de jonk Japan ${ }^{+}$in de voornoemde reviere compt te arriveeren, alle de gevangens te wedersijden ont-

${ }^{1}$ Seguro: Portugeesch $=$ vrijgeleide.

Uit het Contractboek.

3 Dus geen groote Nederlandsche schepen worden toegelaten, alleen jonken.

4 Mij niet geheel duidelijk, al laat de zin omtrent de bedoeling geen twijfel over. 
slagen ende vrij gegeven sullen werden, mits dat de twee koopluijden der Hollanders op een joncke, dat Songia daertoe zall verleenen, voor Aijmoij ende Collongsou w ${ }^{1}$ den handell zullen vervorderen ende een derselver tot Songias versekeringe in een sijner jonken alle waghten comen slapen ende des daeghs Comps dienst waernemen.

Ten derden dat geen Hollanders sullen vermogen aen lant te komen sonder Songia sijn licentien.

Ten vierden sall Songia gehouden blijven, alle coopluijden met hunne waeren vrij ende liber met de Hollandrs te handelen aen boordt van die joncque te laten comen.

Ten vijffden sall Songia met alle coopluijden, die sulx senden ${ }^{2}$ mogen versoeken, met hunne coopmanschappen vrij ende lijber naer Taijoan ende Batavia laten vertrecken.

Ten sesden sullen de Hollanders alle hunne waren ende coopmanschappen, die sij met jonken in voornoemde reviere zouden mogen brengen, aen alle coopluijden vrij en lijber mogen verkopen offte verhandelen, zonder gehouden te zijn, aen Songia offte ijmandt anders allvooren presentatie derselver te doen.

Belangende de restitue ende vergoedinge van 't jaght Domburgh, 3 desselffs dependentie, jngeladen goederen ende vordere, bij Songia van de Hollanders verovert, alle 't selve sall ongedecideert ende tot nader ordre van d'E. $\mathrm{H}^{\mathrm{r}}$ Gener ${ }^{\mathrm{l}}$ open blijven.

Ten $7^{\mathrm{e}}$ sall Songia aen de Comp ${ }^{\mathrm{e}}$ ter handt stellen vier goede joncken omme met deselve haere beliefften te doen.

Ten laesten sall Songia ook gehouden zijn, alle de uijtstaende schullden, die de Hollanders in China hebben, hellpen jnvorderen, daertoe alle faveur ende gunste aen die geene, die sulcx bij der handt souden mogen nemen, betoonende.

Alle poincten, artijkelen ende conditiën wij ondergeschreven ten wederzijden beloovende vast, bondigh ende onverbreekelijck te sullen houden ende doen houden ter tijt ende wijle de ratificatie des Ed. $\mathrm{H}^{\mathrm{r}}$ Gouvern $^{\mathrm{r}}$ Gener ${ }^{\mathrm{l}}$ van Batavia soude mogen becomen.

Actum jn de riviere Chincheo, desen $3^{\text {en }}$ December $A^{\circ} 1630$.

1 Ko-long-soe, eiland gelegen tegenover Amoy.

2 Schrijffout voor "souden"?

3 Zie hiervóór. 


\section{KUST VAN KOROMANDEL.}

$1630 ?^{1}$

De datum van dezen ferman is niet stellig aan te geven. Hij moet gesteld worden na den (trouwens evenzeer onzekeren) van $\mathrm{N}^{\circ} \mathrm{XCV}$ en vóór 1631. Immers minstens 25 November 1630 waren wij weer in Mazulipatam gevestigd (Dagh-Register 1631-1634, bldz. 1, 7). Nu kan dit eerst eenigen tijd later in Golconda bekend zijn geworden en zóódoende is het mogelijk, dat deze ferman van het eind 1630 dagteekent, wat ook overeenkomt met zijne plaats in het Contractboek, tusschen 3 December 1630 en October 1631.

Firman door den koninck van Golconda aen d' $\mathrm{H}^{\mathrm{r}}$ gouvern $^{\mathrm{r}}$ Marten Jijssebrantsoon gesonden. Boven firman stondt de Conings naem : sullthan Abdola Godap Chia.

Jck, de koninck, zijnde aen de Cap $^{\mathrm{n}}$ Moor van de Holland ${ }^{\mathrm{rs}} \mathrm{jn}$ Masulipatnam dit mijn firman, dat de geheele werelt waerdt is. Jck hebbe verstaen, dat UE. met den gouvern ${ }^{r}$ van Masulipatnam eenige quetstsie heefft gehadt ende daerover UE. ende UE. goederen aen boordt van UE. schepen hebt begeven. Jck hebbe daerover den Gouvern $^{r}$ opontboden ende in $d^{0}$ plaets den Chagie Mierhosijn ${ }^{2}$ gesouden, omme UE. te contenteren. Met do hebben aen UE. gesonden eene firman ${ }^{3}$ ende tasserij ende $d^{\circ}$ gelast UE. het tasserij visiteert, ${ }^{4}$ zall mijne groote vrundschap geschieden, ende voorts wederomme aen landt komt ende UE. negotie naer begeeren drijfft. UE. en heefft niet meer als de 3000 pagoden jaerlijcx te betalen. Voorders zall UE. geen molest van niemandt wien 't soude mogen wesen aengedaen werden. Ons verwondert, UEd. overt sellve niet aen landt zijt gecomen; connen ook d'oorsaek niet weten, waeromme UE. hem niet en laet contenteeren, zoo UE. voor de betalinge van UE. uijtstaende schullden hebt becomen, niet en geliefft aen landt te comen. Jck hebbe aen de Gouvern ${ }^{\mathrm{r}}$ geschreven [dat hij] UE. schuldt inmaendt van wien 't zoude mogen wezen ende UE. jntregeerdt offt soo $d^{\circ}$ van de schulldenaers geen betalinge becomt, dat [hij] UE. alsdan de schulldenaers jntrageerdt. UE. magh met haer handelen ende tot betalinge dwingen tot UE. gelieffte offte zoo best goedt vindt. Voorder zoo UE. over t'een off

1 Uit het Contractboek.

? Vgl. hiervóór, bldz. 235.

s $\mathrm{N}^{\circ} \mathrm{XCV}$.

${ }_{4}^{4}$ Hier is de tekst verdorven. 
t'ander meerder hebt te pretendeeren offte claghtigh te vallen, geliefft een van UE. S ${ }^{\text {res } 1}$ hier te laten komen ende mondelinge rapport van alles doen. UE. sall goedt reght ende justitie gedaen werden. Ons verwondert, UE. sonder aen ons claghtigh te vallen offte ons te kennen zoo zijt van Masulipatnam vertrocken. Liever hadde gewenst dat UE. hier reght versoght hadde, zoudent UE. niet geweijgert hebben, dogh is nu geschiet etca. UE laet dogh hem jn aller manieren contenteeren ende gezeggen off laet een als voornoemt hier mondelingh rapport comen doen. Voorts eijndige.

Dit firman sall UE. mede voor segoura off caull dienen.

\section{PERZIË.}

7 Februari 1631. 2

-Na het eerste optreden der O. I. C. in Perzië (zie hiervóór, bldz. 183, v.v.) in 1623, was daar de handel met goede resultaten voortgezet onder leiding van Visnich, die zich in de gunst van den Sjah mocht blijven verheugen, terwijl de commercieële voordeelen van het handeldrijven met de Nederlanders voor diens rijk de verhoudingen ook van zijne zijde steeds meer deden bevestigen. Ook de autoriteiten in Nederland zelf werden weder in de Perzische aangelegenheden betrokken. In 1625 reeds zond sjah Abbas een gezant via het Nederlandsch kantoor te Surat, vanwáár schepen rechtstreeks naar patria vertrokken, naar Nederland in overleg met Visnich, maar zeer tegen den zin der Bewindhebbers, "wegens 't derven van profijten", daar de gezant 100 balen zijde voor rekening van den Sjah meêbracht, wat slechts kon dienen, om hier de markt der O. I. C. te bederven. Hij was vergezeld door Jan Lucassen Hasselt, met hem "vuyt Persia" gekomen. De gezant werd door de StatenGeneraal met veel eerbetoon ontvangen. Hij had zich in Den Haag gevestigd, waar hij „bij 't Landt gelogieert is in een schoon paleys toecomende den ambassadeur van Sweden". De O. I. C. ruimde hem en zijn gevolg een huis te Amsterdam in en legde hem een som tot onderhoud toe. Al spoedig echter kwam tusschen den gezant c. s. en de Bewindhebbers een minder aangename verhouding: volgens dezen hadden eerstgenoemden hunne beleefdheden met ondank beloond. Bewindhebbers namen maatregelen, dat deze vreemdelingen in Nederland geene specerijen zouden kunnen opkoopen. Zonder directe resultaten keerde de Perzische gezant met de zijnen naar Perzië terug in Maart 1627, óók bij zijn vertrek met eerebetoon behandeld en met een brief aan den Sjah voorzien. Ook de Bewindhebbers wilden den Perzischen handel "met een

1 Senhores?

2 Overgenomen uit Valentijn, V, 1 (Persien), bldz. 296. - Ook opgenomen in Placaet-Boeck, II (1664), kol. 1319. 
aanzienlijke macht maintineeren", te meer nu in Portugal en Spanje stemmen opgingen, om de O. I. C. af te snijden juist van den handel in VóórIndië en Perzië. En die commercie was zéér voordeelig: voor ongeveer f 400,000 in contanten en koopmanschappen kocht men 900 balen zijde, die in Nederland rendeerden omtrent $f 1,300,000$.

Gedurende hun gezantschap had Hasselt oneenigheid gekregen met den Perzischen ambassadeur en hij vertrok vóór hem weder naar Perzië. Bij zijn terugkomst weet deze Nederlander het oor van den Sjah te winnen en wordt door den Vorst in het laatst van 1628 weder naar Nederland afgevaardigd. Hij kwam hier op een schip der O. I. C., via Batavia, met credentiebrieven voor de Staten-Generaal. Doel van zijne zending was het verkrijgen van vrijen handel, wat natuurlijk door de O. I. C. wordt tegen gewerkt. Hij zag kans, de onderstaande overeenkomst te sluiten. De O. I. C. ging haar eigen gang in Perzië, onafhankelijk van deze conventie ${ }^{1}$ (Vgl. Onuitgegeven missives van Bewindhebbers aan G. G. \& R., 8 Dec. 1625, April 1626, 1 October 1626, 3 April 1628, 28 Aug. 1629; aan Visnich, 5 Jan. 1626, 4 Aug. 1626; onuitgegeven resoluties van Bewindhebbers, 20, 27 Aug., 24, 31 Oct. 1626; onuitgegeven acte der Stat. Gen. "tot goet tractement en onthael van de $H^{r}$ Ambassadeur Mouça Begh, keerende naar Persië", 11 Febr. 1627; onuitgegeven missive der Stat. Gen. aan den Sjah, 14 Maart 1627; onuitgegeven missives van Visnich, 1 Nov. 1628 , en van G. G. \& R., 3 Nov. 1628, aan Bewindhebbers; onuitgegeven "Propositie" uit naam van den Sjah aan de St. Gen. van J. L. Hasselt, 26 Juni 1630 , enz.).

Capitulatie en Articulen van wegen den Koning van Persia ${ }^{2}$, gemaakt met de hoog Mogende Heeren de Staten Generaal der vereenigde Nederlanden, door Johan van Hasselt, Agent van wegen den hoogst-gedagten Koning, bij de hoog gemelde Staten Generaal residerende ${ }^{3}$, in data den 7 February 1631.

Dat de hoog Mogende Heeren Staten Generaal der Vereenigde Nederlanden vergunt hebben, gelyk haar hoog Mogende vergunnen mits dezen aan de Persiaansche Natie hier te lande komende, uyt

${ }^{1} \mathrm{Zij}$ behoort dan ook strikt genomen niet in deze verzameling tehuis, maar volledigheidshalve nam ik haar over, nu zij aanvult de geschiedenis onzer verhoudingen met Perzië.

2 Niet meer sjah Abbas, die in 1627 of 1628 overleed, maar zijn opvolger, Sefi of Sofi.

3 Deze Hasselt of Van Hasselt (hij teekent óók Jan Lucassen Hasselt) moet niet worden verward met Jan van Hasel of Van Hazel, een hooggeplaatst ambtenaar der O. I. C. in deze dagen, die o. a. ook haar heeft gediend in Surat.

Met onzen Hasselt wordt bedoeld de Nederlandsche "Meester schilder" aan 't Perzische hof, over wien P. A. Leupe in De Nederlandsche Spectator 1873 , bldz. 261, eenige bijzonderheden geeft, die over 't geheel juist zijn, al zijn zij voor aanvulling vatbaar. 
den naam van den meer hoogst-gedagten Koning, of ook in haar particulier, vry gelyde en pas in alle plaatsen en steden, gẹlegen in de Geunieerde Provincien ofte 't ressort van dien, omme vry en ongemolesteert te gaan, komen en weder keeren, ook handelen, koopen en verkoopen allerley waren en koopmanschappen, geene uytgezondert, zulks als de zelve Natie zal goet dunken, en hunne Negotie meinen vorderlyk te wezen.

Dat de zelve Persiaansche Natie binnen deze Landen genieten zal alle zoodanige vrydommen en geregtigheden, als de Ingezetenen dezer Landen zyn genietende, ja ook zelfs de perzoonen van qualiteit, die binnen deze Landen groote Ampten en Officien bekleeden, zoo wanueer als zy zich met de Negotie willen vermengen.

En ingevalle de Persiaansche Natie binnen hunne huizen quamen te koopen ofte verkoopen eenige waren en koopmanschappen, dat ze in zulken kas zullen mogen gebruiken haar eygen elle, ook haar gewichte en mate, ten ware zaake dat zij kogten ofte verkogten een groote quantiteyt goederen en koopmanschappen, die de mate ofte wege subject zouden mogen zijn, in welken gevalle zoodanige groote quantiteyt in 't meeten en wegen gereguleert zal werden, volgens d'ordre van 't Landt, die met goede kennisse en circumspectie is beraamt, ten eynde de kooper ofte verkooper in de mate ofte gewichte niet en werde bedrogen ofte verkort ${ }^{1}$.

Indien het gebeurde, dat eenige van de gemelde Persiaansche Natie binnen deze Landen quam te overlyden, zonder yemand by hem te hebben, die op des Konings, ofte den overledenens particuliere goederen, acht name, in zulken gevallen zullen de Heeren Regeerders van de Residentie-plaatse des overledenen zorge dragen, dat alle de nagelatene goederen des Konings van Persia, ofte des overledens particuliere goederen, behoorlyk werden geinventariseert, en in bewaarder hand genomen, ter tyd en wyle toe dat van wegen den hoogst gedagten Koning, ten reguarde van Zyner Majesteits goederen, ofte van des overledenens vrienden en magen, ten reguarde van zyne particuliere goederen, daarinne anders zal wezen voorzien. Ende zullen middeler-tijd de consumptibele ofte bederffelyke waren na gelegentheid van zake werden gebenificeert ten behoeve van den hoogst gedachten Koning, ofte overledenens Erfgenamen in 't par-

1 Vgl. hierbij en bij verschillende andere bepalingen dezer overeenkomst het tractaat van 1623 (hiervóór bldz. 186 v.v.), dat dikwijls zijn terugslag vindt in dit tractaat. 
ticulier: doende van de gebeneficeerde waren en koopmanschappen behoorlijke reekeninge, bewys en reliqua.

De Persiaansche koopluiden, zoo wanneer zy in competent getal met een goet kapitaal binnen deze Landen zullen zyn gearriveert om te negotieeren, zullen te samen van een bequame wooninge werden versien, en genieten ter plaatse van hunne residentie vrydom van d'Imposten op de consumptibele waren die in hunne huishoudinge sullen worden geconsumeert; gelyk ook van een bequame huysinge sullen worden versien, en vrydom genieten als vooren die geenen die by Commissie van den hoogst gedagten Koning van Persia de voorschreven Natie alhier zal representeren en 't Hoofd daarvan zyn.

Het huys van den Agent van Zyne Koninklijke Majesteit van Persien zal zyn en blyven geprivilegeert, gelyk de huisen van andere Agenten van Koningen en Prinsen in Europa, die by 't Hof van de hoog gemelde Staten Generaal resideren. En zal de Persiaansche Natie in deze Landen een Comptoir, versien van Volk en Capitalen, geërrigeert hebbende, zoo wel ten reguarde van de commercie, als stuk van de Justitie genieten zoodanig regt, voordeelen en geregtigheyd, als de Engelsche Court residerende binnen de stadt Delft, en de Schotsche Natie residerende binnen de stadt Campvere ${ }^{1}$, respectieve zyn genietende, met welker Natien Koning de hoog gemelte Staten Generaal van ouder tyden Accoorden en Entercouren $^{2}$ op 't stuk van de Negotie hebben gemaakt, ende onderhouden.

De Persiaansche Natie zal ook toegelaten werden in hare huysinge alle vrydom, liberteyt, en exercitie van Religie, zonder daar inne by iemand, wie het ook zoude mogen wesen, verhinderd, gemolesteerd, ofte ontrust te werden.

Ingevalle iemant van de Persiaansche Natie van zyne Religie wilde veranderen, 't selve sullen de hoog Mogende Heeren Staaten zig niet aantrekken, maar in allen gevalle zal de Koning, of iemand anders, die onder soodanig persoon goederen mogt hebben, daarom van deselve goederen niet werden versteken ofte ontzet, maar zal de selve persoon als bevorens ter zake van zyue administratie mogen aangesproken, en in regten geconvenieerd werden.

De Persiaansche Natie zal aangewesen werden een plaats, alwaar

1 Veere.

2 Intercoursen, intercursus. 
zy haare dooden naar haar gebruik en gewoonte zullen mogen begraven.

Ingevalle iemand van de Persiaansche Natie jegens den Agent van den meer hoogst-gedagten Koning zig quam te verloopen, misgrypen, ofte opponeeren, zal de Justitie ter plaatse van het delict, des versogt zynde, den voornoemden Agent de hand bieden, ende over soodanigen persoon, ofte persoonen, regt doen, sulks als men na gelegenheden van zaaken bevinden zal te behooren.

Gedaan ter vergadering van de hooggemelde Staaten Generaal, in 's Gravenhage, op den sevenden Februari 1631.

\section{KUST VAN KOROMANDEL.}

1631. 1

De strekking van dit kaul is duidelijk. De vorst van Carnatica, Sri Rama Dewa Rajah, die het kaul van 14 November 1629 ( $\mathrm{n}^{\circ}$ XCII) had verleend, was overleden. Maarten IJsbrantsz heeft bevestiging daarvan gevraagd en bij onderstaand schrijven deze confirmatie ontvangen van den nieuwen vorst, die- "kort bevoorens den overleedenen" was "gevolgd" (Contractboek Zeeland: aanteekening bij het dáár opgenomen exemplaar van dit kaul).

Confirmatie van den koninck van Carnatica over t' caull, bij den overleden koninck Rama Dewa Raija ons verleent, ontfangen $\mathrm{A}^{0}$. 1631 naer de volle maen in October.

Naer gewoonlijcke tijtell: Zende desen brieff van geloove apn den gouvern ${ }^{r}$ der Hollanders Marten Isbrantszoon. Van UE. ambassad ${ }^{\text {rs }}$ Padmanaba ${ }^{2}$ ende Wardapa hebbe UE. versoeck alles verstaen. UE. zijt alltijt vasste coopluijden van Konings huis. 't Caull, door den $k^{k}{ }^{k}$ Rama Dewa Raija UE. verleent, confirmeere bij desen ende sall voor alltoos naercoomen, waerinne UE. sonder eenigh aghterdencken in eeniger manieren mooght vertrouwen. Geloofft mijnen ende drijft UE. negotie op mijn segoure, sonder eenige vreese,

1 Uit het Contractboek.

2 Vgl. hiervóór, bldz. 195. - Hij was een der leveranciers van de O. I. C. voor de Kustkleeden. 
met contentement, waerop desen van geloove hebben gegeven. Onderstondt Seri Wenkatesa ${ }^{1}$.

\section{KUST VAN KOROMANDEL.}

1631. ${ }^{2}$

Zooals reeds bleek (zie hiervóór, bldz. 101, 159, v., 194), schonken weg of verpachtten de vorsten van Carnatica de inkomsten van Pulicat, waarin wij het kasteel Geldria hadden, welks omgeving echter geen grondgebied der O. I. C. was. In de laatste jaren komt hierbij op den voorgrond een zekere "Maleije" of "Malaije" s, een man, met wien de onzen reeds sedert eenige jaren in aanraking waren (Vgl. hiervóór, bldz. 194 v.). Ook de O. I. C. begint in de voordeelen der tollen van Pulicat en sommige omliggende plaatsen te deelen, gelijk geheel hare stelling hier steeds gunstiger wordt.

Caull wegen de groote sioncan van Palleacatta $\mathrm{A}^{\circ} 1631$ naer de volle maen in sber.

Naer den tijtell: Wencketa Pete Raija: zende UE. dese mijn oole $^{4}$ aen de gouvern ${ }^{\mathrm{r}}$ van de Hollanders ende Maleije. Voor dese heefft Rame Dewa Raija UE. geschoncken ${ }^{5}$ de dorpen Carongoer ${ }^{6}$ ende Perombeur ${ }^{7}$. Jck hadde UE. Aresour ${ }^{8}$ oock geschoncken, in plaetse van welcke drie dorpen ick UE. nu schenke de groote groote sionkan van Palliacatta, bhomij sionkan. Dat deselve op-

1 Het Contractboek Zeeland noemt deze vorst: „Srie Wenkatesa of Wenketapete Raija." Vgl. hiervóór, bldz. 84, 85. - Wenkata is een andere naam voor Tripati of Tirupati, een heilige plaats ten N. O. van Chandragiri en ten N. W. van Madras (Vgl. Hunter, Gazetteer, IX, p. 93). - Dus de vorst van Carnatica (Chandragiri) noemt zich ook vorst (pati) van Wenkata. In een ander stuk, van 24 December 1629, vond ik (Contractboek Zeeland), dat hij zweert „bij mijnen God Wenketese."

2 Uit het Contractboek.

3 Vgl. hiervóór, bldz. 231, noot 1.

4 Ola, een geschreven bevel, dienstbrief (Hobson-Jobson, p. 485).

5 Van deze schenking heb ik het ola niet aangetroffen.

6 Karanguli (ten Z. W. van Madras, ten Z. der Palar-rivier)? Vgl. Hunter, Gazetteer, V, p. 246.

7 Waarschijnlijk een der tegenwoordige voorsteden van Madras, Perambur (Hunter, Gazetteer, VI, p. 163).

8 Deze schenking trof ik niet aan. - Het Contractboek Zeeland heeft Aretoer. Ik durf de ligging er van niet te gissen. 
brengt mooght UE. deelen, als voor deesen met de dorpen gedaen hebt. Onder stondt Seri Wenckatesa ${ }^{1}$.

\section{AMBON.}

\section{November 1631. ${ }^{2}$}

Philips Lucasz werd in 1631 als gouverneur van Ambon opgevolgd door Artus Gijsels. ${ }^{3}$ Tot de krijgsbedrijven onder zijn bestuur, waarin het op deze eilandengroep allesbehalve rustig was, behoort eene expeditie tegen Tobo, aan de Zuidoostkust van Ceram, dat tegen ons in verzet was ook door toedoen van gevluchte Bandaneezen. De negerij legde het hoofd in den schoot zonder tegenstand van eenige beteekenis (TieleHeeres, Bouwstoffen, II, bldz. XLVI, 195-198).

Copie van 't accoord gemaakt, en gelaten in handen van den Orangkay van Tobo.

Op huiden den laatsten November, 1631, de Ed. heer Gouverneur Artus Gysels, nevens de respectieve officieren, ende Orangkaja's der Nederlandsche Staat in deze quartieren Amboina, met de magt van 't Krijgs-volk voor de negory Tobo, op den 21 dezer verschenen zynde, en deze plaats tot heeden toe rondom belegert wezende, om door deszelfs middel na regt, reden, en in redelykheid, een harer begane fouten van ontrouw op 't aanzienlijkste met reputatie te straffen, zoo is 't nu evenwel zulx, dat aangezien de

1 In het Contractboek Zeeland vindt men hierbij de volgende noot: „Anno 1635 heeft den Koning dit voorregt geheel aan Maleije gegeven, sijnde niet den bovengeschreven Maleije, maar desselfs broeder Chinanna Chittij, en daar en teegen d'E. Compagnie Erikan gegeeven. Dog den Gouverneur is met Maleije overeengekomen, daar in geen verandering te brengen, maar Maleije te laten volgen de helft uijt de inkomsten van Erikan, door hem daar en teegen nog aan d'E. Compagnie overgedaan 't dorp Mansjewake." De in deze noot genoemde plaatsen vind ik bij Hunter niet, maar op de kaart van Koromandel bij Valentijn vindt men twee eilandjes van die namen ten Noorden van Pulicat. Dat deze de bovengenoemde plaatsen zijn, blijkt uit Valentijn, V, 1 (Choromandel), a, bldz. 14; Havart, Cornmandel, I, bldz. 105, waaruit trouwens Valentijn heeft overgenomen, enz.

De vroegere "Maleije" was in Maart 1634 overleden (Dagh-Register 16311634 , bldz. 364, v.).

${ }^{2}$ Overgenomen uit Valentijn, II (Ambon), b, bldz. 87. - Deze datum bij Valentijn is zeker juister dan die van 30 December, zooals voorkomt bij Tiele-Heeres, Bouwstoffen, II, bldz. 197.

3 1631-1634. 
Orangkaja's, alsmede de gemeene inwoonders van voorz. Tobo, instantelyk verzoeken, dat wy de verdiende straffen uit medogentheid, hen voor deze reize gratieuselyk willen vergeven, wy jegenswoordig uit verscheide inzichten ons wel beradende, haar ootmoedelyk verzoek, onder deze stipulatie haarder beloften, waaragtig toestaan en accorderen, namentlyk

Ten eersten, dat de Orangkays, ende gemeene inwoonders der voornoemde negery Tobo, van nu eeuwig zullen verpligt, verbonden, ende onderdanig blyven, de Ed. Hoog Mogende Heeren Staten Generaal der Vereenigde vrye Nederlanden, zvn Vorstelyke genade, Frederik Hendrik, by de gratie Godes, Prince van Orangie, \&c., de geoctroyeerde Oost-Indische Compagnie, mitsgaders haar Ed. subalterne Regters dezer India's.

Ten tweede, dat jegenswoordig tot teken van waarheid twee der.principale Hoofden haar kinderen onder opzigt van zijn Ed. in 't Kasteel ${ }^{1}$ zullen gehouden, en tot nader belieften aldaar opgetrokken ${ }^{2}$ worden.

Ten derden, dat zy preciselyk alle jaren zullen gehouden zijn tweemaal, ofte ten minsten eens, met een of meerder vaartuigen, aan 't kasteel te verschynen.

Ten vierden, dat $[\mathrm{zy}]$ alle verlopen slaven uit de quartieren van Amboina, Banda, ofte Moluccos, gehouden blyven voor de zomme van vyftien realen, t'haarder komste in Amboina, Banda, ofte de Moluccos, aan de Compagnie over te leveren, ofte aan de eigenaars van de gemelde plaatzen, op Tobo komende, voor de zomme van thien realen gewillig te laten volgen.

Ten vyfden, dat de gemelde Orangkay, ofte inwoonders dier meergemelde plaats, van nu af geaccordeerd, ende toegestaan werd met praeuwen, ofte groter vaartuigen, zoo wel in de quartieren Amboina als Banda, vry ende vrank te mogen navigeren, met zoodanige vryheid, als andere onderdanen, onder het Kasteel zorterende ${ }^{3}$.

Eindelyk, dat na den dag van heden niet zullen vermogen met eenige onzer onderdanen 't zy van Amboina, de Eilanden, Ulliassers, ${ }^{4}$ ofte zelf op de kusten van Ceram, in oorlog te treden, zonder expresse last, ofte kennisse des Ed. Heer Gouverneur van Amboina.

Ende op dat dit bovenstaande met meerder kragt gevolgd werde, beloven wy gemelde Tobo, neffens de inwoonderen van dien, tegens

1 Victoria.

2 Opgevoed.

${ }^{3}$ Ressorteerende.

4 Zal wel moeten zijn: de eilanden Uliassers. 
alle geweld, lasten ende prejudiciabele attentaten ernstelyk te zullen beschermen; blykende dan, dat dit bovenstaande aan onze zyde getrouw ende opregtelyk naagekomen zal werden, zoo is dit tot teken der waarheid, als een vaste belofte met eigene handen ondertekend, ende met onze gewoonlyke signature bekrachtigt. Aldus gedaan, ende geaccordeerd, in de bezettinge voor Tobo, datum ut supra, ende was onderteikend, Artus Gysels, Evert Hulft, Joan Ottens, en M. Rombouts, Secretaris.

\section{PERZIË.}

\section{November-December $1632 .{ }^{1}$}

Zooals reeds bleek (zie hiervóór no CI) was, na onze eerste vestiging in Perzië de handel (de zijdehandel in de eerste plaats) dáár door de onzen met goede resultaten voortgezet en had zelfs de Sjah zich in verbinding gesteld met de Nederlandsche regeering zelve. Tamelijk wel onafhankelijk van deze regeeringsbemoeiingen ging de O. I. C. in Perzië haar eigen gang, welke geleid werd in de eerste jaren door Hubert Visnich, die bij sjah Abbas zeer in gunst stond. Dat de autoriteiten der Compagnie het handelsbelang van Perzië niet gering rekenden, wordt bewezen onder meer door het zenden van een gezant naar het Hof: in 1628 ging als ambassadeur Jan Janszoon Smit of Smidt, opperkoopman in dienst der maatschappij, om den nieuwen sjah Sofi (Sefi, Safi), opvolger van Abbas, te begroeten. Veel resultaten had deze zending niet, vermoedelijk óók ten gevolge van oneenigheden tusschen Visnich en Smidt. Toen onderstaand bevelschrift door den Vorst werd uitgevaardigd, was het echter niet langer Visnich, die onze belangen aldaar had te behartigen. Hij had zich de ontevredenheid dẹr Bewindhebbers op den hals gehaald door minder zorgvuldig beleid van de commercie, was niet zuiver op de graat op het punt van particulieren handel enz. In Aug. 1629 werd uit Batavia als zijn opvolger gezonden de opperkoopman Antonio del Court, die tevens bij den nieuwen sjah moest aandringen op bevestiging der voorrechten, ons door Abbas verleend. Toen Del Court in 1630 in Perzië verscheen, wist Visnich „door suptylheijt" zijne handen te ontkomen. ${ }^{2}$ Ook wilde de nieuwe sjah het tractaat door Abbas met Visnich gesloten in 1623 niet zoo dadelijk erkennen. Er waren enkele handelsgeschillen tusschen hem en de O. I. C. gerezen, die hij eerst wilde zien uit den weg geruimd. Wel wilde hij onderstaand bevelschrift op verzoek van Del Court uitvaardigen en had hij verder

1 Uit Contraetboek Amsterdam III.

2 Volgens hier te lande ontvangen berichten was hij met veel geld en kostbaarheden te Aleppo gekomen, waar hij als spion werd beschouwd "door zekeren vizier van den Grooten Heer" en "gestranguleerd", waarna de Vizier zich zijne bezittingen had toegeëigend (Vgl. onuitgegeven missive van Bewindh. aan G. G. \& R., April 1632). 
geen bezwaar, den Nederlanders vrijen handel in zijn rijk te vergunnen (Vgl. Dagh-Register 1624-1629, en 1631-1634, passim; Mijer, Instructiën, bldz. 57, v.; onuitgegeven missives aan Bewindhebbers van G. G. \& R. 13 Dec. 1626,3 Nov. 1628, van den G. G. Specx, 7 Maart 1631, van Philips Lucasz., 29 Febr. 1632; onuitgegeven missive van G. G. \& R. aan J. van Hazel te Surat, 11 Aug. 1628; onuitgegeven missives van Bewindhebbers aan G. G. \& R., 3 April, 25 Oct. 1628, 27 April, 23 Nov. 1631).

Bevelschrift ${ }^{1}$ wegens de vrijheijt der raachdarijen van soodanige coopmanschappen als naer boven ${ }^{2}$, om met den Persischen coninck te handelen, gevoert, gelijck mede van de sijde en andere goederen, die tegens en in plaets van voorschreven coopmanschappen weder aangenomen en naer beneden afgebracht werden, verleent op de rahdaars tusschen Spahan en Gamron door den coninck Abbaas de Groote en daernaer vernieuwt bij den coninck Sophie d'Eerste, in de maendt Zjumadie el-Awwel des jaers 1042 naer de vlucht Muhammedt uijt Mecca naer Mediena, over een comende met de maent ... ${ }^{3}$ des jaers .... ${ }^{3}$ naer de geboorte Christi ${ }^{4}$.

5 Daer is een gebodt van de werelt te gehoorsamen geschiet, namentlijck dit:

De raghdaers en bewaerders en de ontfangers en reeckeninghouders en de pagters vande grote wegen ${ }^{6}$ van Isfahaan, de woninge van heerschappie ${ }^{7}$, en van Aberkoeh ${ }^{8}$ en van Iesd ${ }^{9}$, de woning van

${ }^{1}$ "Translaet uijt het Persiaens": niet echter gelijktijdig maar uit de tweede helft der $17^{\text {do }}$ eeuw.

2 Van Bender Abbas (Gamron) dus naar Ispahan. Bender Abbas is genoemd naar den bekenden sjah.

3 Niet ingevuld.

4 De maand Djoemada' l-awwal 1042 loopt van 14 November 1632 tot 13 December.

${ }^{5}$ Hiervóór: „L. S. van den Coninck Safie d'eerste....."

"Rachdars" enz. „en beteekenen geen ampt onderscheyden maar een en derselve personen, alleenelijck met diversche benamingen, naer 't onderscheijt van haer werck, en plicht gedesigneert....." (Zeventiende-eeuwsche kantteekening bij dit document).

7 Nl. een der residentiën van den Sjah.

8 Volgens eene zeventiende-eeuwsche aanteekening bij dit document: „een stedeken tusschen het casteel Jesdechaast en de stadt Zjieraaz", waarlangs in die dagen ging de "sijde-cafilah" (karavaan) der O. I. C. Jesdichast ligt ten Z. O. van Ispahan.

9 Jesd, ten Z. O. van Ispahan. De naam „woning van godsdienstigheijt" is aan Jesd "geattribueerd" "vermits de beroemtheijt van veele godtvruchtige lieden in voorleden eeuwen." 
godsdienstigheijt en van andere grooten passagien, (die weten) dat nademaal bij het bevelschrift des prince van de rustplaets des Paradijs en van het lusthoff des Goddelijcke paleijs, den coninck mijn Vader (welckers religie Godt verglanse) geordonneert sij, dat van de specerijen en droogen stoffen ende ${ }^{1}$ dewelke den Capit $^{\mathrm{n}}$ der Hollanders en desselfs volk, ten eijnde om met [het] hooghaensienelijck hoff te verhandelen, in Bandaer ${ }^{2}$ aenbrengen, gelijck mede van de sijde ende $^{3}$ dewelke tegens en in plaetse van deselve aennemen en voor haer eijgen vervoeren ${ }^{4}$, ter oorsaeck en van wegens de tienden en raahdarijen niets en eijsschen nochte (daerover) moeijelijck vallen, soo jst dat wij, ordonnerende, bevoolen hebben dat de raahdaers en de bewaarders en d'ontfangers en reeckeninghhouders van voorschreven wegen, volgens de coustumen (van dit landt) ter oorsaeck en van wegens de raahdarijen niets en eijsschen noghte verwachten, noch oock (daerover) tegens haer in 't minste contrarieren en (wij hebben oock ordonnerende bevolen) dat zij (Hollanderen) alle jaeren hiervan geen nieuw bevelschrift te versoecken hebben; ende wanneer dit bevelschrift met het hooghaensienelijck zegel van een sous(?) affsteecksel (?) sal verciert werden, dan stellen daerin volcomen gelooff en vertrouwen.

Geschreven in de mant Zjumadie el-Awwel des jaers 1042. ${ }^{5}$

\section{SINT-HELENA. ${ }^{6}$}

\section{April 1633. ?}

Sint-Helena, door de Portugeezen in 1502 ontdekt, was sedert de tochten der Nederlanders naar het Oosten ook door dezen natuurlijk

\footnotetext{
1 Enz.?

2 Bender Abbas = Gamron.

3 Enz.?

4 Vgl. hiervóór, bldz. 185.

${ }^{5}$ In Contractboek Amsterdam III bevindt zich nog een "bevelschrift wegens de vrijheijt der Gamronsen thol", enz...... nals oock wegens 't verloff van met ijder schip twee stucx paerden te vervoeren," uitgevaardigd ten bate der Nederlanders door sjah Abbas en thans „vernieuwt bij den coninck Saphie d'Eerste. In de maendt Zjumadie de tweede des jaers 1042" (dus tusschen 14 Dec. 1632 en 12 Jan. 1633). Ik vond niet noodig dit op te nemen. Evenmin een soortgelijk bevelschrift als dit nummer bevat, maar dagteekenende van 1634 .

6 Ofschoon dit eiland valt buiten de grenzen, door haar octrooi gesteld aan den werkkring der O. I. C., neem ik deze acte van inbezitneming hier op, omdat zij plaats vond door een vloot van dit handelslichaam.

7 Origineel. - Uit de aanwinsten van het Rijksarchief (Zie Verslagen $X V I I$ 1894, bldz. 63). - Het stuk draagt nòg de sporen van bevestigd te zijn op een voorwerp: zeker de "pilaer," waarvan beneden sprake is.
} 
herhaaldelijk aangedaan, vooral op de retourreis. Toen de oud-gouverneurgeneraal Jacques Specx bij zijn repatrieering (December 1632) het eiland aandeed (onuitgegeven missive van Specx aan de Kamer Amsterdam, $6 \mathrm{Mei}$ 1633), nam hij het voor de Staten-Generaal in bezit, als teeken waarvan hij onderstaande acte op het eiland achterliet. Na allerlei lotwisselingen, waarbij het eiland beurtelings in handen der Nederlanders en der Engelschen kwam, werd het in Mei 1673 door laatstgenoemden heroverd, waarna het in hun bezit is gebleven (Theal, South Africa 1652, I, p. 107, 205-207; vgl. Dagverhaal Van Riebeek, III, bldz. 236, 277-279, 392).

Op dato $15^{\text {en }}$ Aprilis $A^{\circ} 1633$ hebben den E. Heer Jacques Specx, oudt Gouvern ${ }^{r}$ Generael, wegen den Staet der Vereenichde Nederlanden in Jndia, t'saempt den Breeden Raedt vande presente alhier gearriveerde Nederlandtse vloote, bestaende in de schepen Prins Willem, de Princesse Emilia, Hollandia, Zutphen, Rotterdam, ende Hoorn, de possessie ende eijgendom van dit eijlandt, van oudts genaempt St. Helena, soo als t'zelve jegenwoordich leght, met alle zijne aenlangende gronden, heuvelen, clippen, ende rotsen, voor den Staedt der Vereenichde Provintien ${ }^{1}$ aengenomen, omme t'zelve ten besten ende voordeel van den gemt ${ }^{\mathrm{n}}$ Nederlandtschen Staet ter eerster gelegentheyt te verstercken, besetten, peupleren ende tegen alle jnvasien van vyanden te beschermen, soo als de Doorluchtige Ho: ende Mog: Heeren Staeten Generael vande gem $^{\text {te }}$ Vereenichde Provintien sullen te raede vinden. Gelijck alles bij ampele, solempnele acte, vande voorschreven aengenomen pocessie ende eygendom in forme gemaeckt, nader blyct. ${ }^{2}$ T'oirconden, ende jn waerheyt van desen, midtsgaders dat niemandt hier van ingnorantie en pretendere, js desen pilaer alhier gerecht, midtsgaders dese notificatie behoorlyck gesegelt, ende geteyckent hier aengeslaegen, ten jaere ende dage als boven.

\section{Lieve Douwis. ${ }^{3}$}

Cornelis Theunissen Drent. 4

Ter ordonnantie vanden gemelten $\mathrm{H}^{\mathrm{r}}$

Generael, ende Breeden Raedt

\section{J. Van Vossele,}

als secretaris. ${ }^{5}$

\footnotetext{
1 Natuurlijk niet voor de O. I. C.

2 Deze "acte" heb ik niet aangetroffen.

${ }^{3}$ In 1632 vice commandeur eener vloot (Dagh-Register 1631-1634, bldz. 89).

4 In 1632 president van het College schepenen te Batavia. (Dagh-Register 1631-1634, bldz. 80).

5 Ter zijde stond het zegel der O. I. C. in rood lak.
}

7• Volgr. III. 


\section{AMBON.}

\section{Juni 1633. 1}

De kapitein Hitoe, „oudt ende des levens sadt sijnde", overleed in April 1633. Hij was in de laatste jaren niet meer de vriend der O. I. C., die hij vroeger geweest was (Vgl. hiervóór, bldz. 170; Tiele-Heeres, Bouwstoffen, II, bldz. XLVI, enz.). „Veele competiteurs hielden hardt aen om zijne plaetse te becleeden; onder andere was Kakialij den principalen die om zijnen vader te mogen succedeeren onse hulpe ende assistentie was versoeckende." Deze hoekoem Kakiali, één der zoons van den overleden kapitein Hitoe, stond mede niet bekend als een vriend der Nederlanders, werd echter door de Nederlandsche autoriteiten voor de opengevallen plaats aangewezen, en zwoer bij zijn optreden trouw aan de O. I. C. De sultan van Ternate was , seer g'altereert ende geliet sich heel verstoort", o. a. over deze houding der Nederlanders; "verstont.... niet, den Generael in Batavia authoriteyt ende macht hadde, een nieuwen Capiteyn Hittoe te creeren, dat hem, coninck, sulex te doen stond." (Dagh-Register 1631-1634, bldz. 197, v.; Bouwstoffen, II, bldz. LVII, 301; Valentijn, t. a. p., bldz. 92,93 ).

Alzoo de ingezetenen van Hitoe door magt en middelen van de generale Nederlandsche Compagnie in den jaere 1605 verlost, en vrygesteld zyn uit 't geweld en de tyranny der Portugeesen, onze algemeene vyanden, en door de zelve wederom gebragt in 't vry bezit, en gebruik van goederen, landen en steden, uit welke zy by gezegde Portugeesen waren verdreven, en dat in recompense van zoo groote weldaden by verscheide contracten, verbintenissen, en eeden, de voorsz. ingezetenen van Hitoe haar zelven vrywillig hebben onderworpen, en verbonden, aan de Hoog Mogende Heeren StatenGeneraal der Vereenigde Nederlanden, ${ }^{2}$ en aan de gemelde Compagnie, maar dat by verloop vau tyden de zelve contracten, verbintenissen, en eeden byna al vergeten, en in veelen gebroken zyn geworden; daar beneveus dat, by versterven van den ouden Capitein Hitoe, des zelfs zoon, Kakiali, met de andre drie Hoofden, ofte Orangkaja's, aldaar ernstelyk hebben verzocht, dat een ander bequaam perzoon in des afgestorvenen plaats, door magt, authorisatie, en bevel van den meergemelden Nederlandschen staat zoude werden verkoren, ingevoerd en erkend, zoo is ' $i$ dat de Heer Arthur Gysels, Raad van India, en de jegenwoordige Heer Commissaris in de quartieren van de Moluccos, Amboina en Banda, Anthoni van den

1 Overgenomen uit Valentijn, II (Ambon), b, bldz. 92.

2 Vgl. hiervóór, ni XIV, XXIX, XXXII, LXXI, XC. 
Heuvel ${ }^{1}$, ook met goedvinden, ende toestemming van de Raaden aldaar present, by provisie, en tot approbatie van den Ed. Hendrik Brouwer, Gouverneur Generaal van India, geresolveerd, ende besloten heeft, dat Kakiali in plaatze van zyn overleden vader tot Capitein, en Opperhoofd op Hitoe zal worden gesteld, zulx hy gesteld werd mitsdezen, daar benevens, dat alle de voorgaande contracten, verbonden en accoorden, tusschen de Vereenigde Nederlanden, en die van Hitoe, opgeregt, van nieuws af geconfirmeerd, ende bevestigt zullen werden, ende dat de voorsz. Kakiali, als Capitein ende Opperhoofd, mitsgaders de andere drie Hoofden en Orangkaja's ten aanhooren ende by goedvindinge van alle smalle Hoofden onder 't gebiet van Hitoe sorterende, met solemnele eeden zullen verklaren ende beloven, de voorsz. contracten onverbrekelyk te houden, ende te agtervolgen, gelyk de zelve hier na volgende, ende uitgedrukt zyn.

Eerstelyk, zoo belooft en zweert Kakiali als Opperhoofd, en Capitein van Hitoe, voor hem, en zyne onderdaanen, mitsgaders Baros, Totohatoe, ende Tanihitoemessing ${ }^{2}$, mede Orangkaja's, ende Hoofden, voor haar, en haar onderdaanen, dat zy de Hooge en Mogende Heeren Staten Generaal, zyn Princelyke Excellentie, ende de Ed: Heeren Bewindhebberen van de Vereenigde Nederlandsche Compagnie, en hier te lande den Ed. Heer Gouverneur Generaal, ende Raaden van India, vooral, en insonderheit, den Gouverneur van Amboina, in alles getrouw ende getrouw zullen zyn; daar beneffens zweeren en beloven zy, dat zy de zelve tegens alle hare vyanden, ofte die haar Ed: beoorlogen, te water ofte te lande, helpen, bystaan, ende assisteeren, zelfs tegen den Kimelaha ${ }^{3}$, ende alle zynen adherenten naar haar uiterste vermogen, met goed en bloed, gelyk getrouwe bondgenoten en vrinden schuldig zyn.

Ten laatsten, zweeren en beloven wy aan niemand anders eenige giroffel-nagelen te verkoopen, dan aan de Koopluiden van de gemelde Compagnie, die dezelve op Hitoe zullen moeten ontfangen, zonder dat die van Hitoe gehouden zyn de nagelen aan 't Kasteel te leveren.

1 Deze commissaris-visitateur over deze gewesten was in het begin van 1633 op Ambon gekomen (Bouwstoffen, II, bldz. LVI; Dagh-Register 16311634, bldz. 138).

2 Vgl. hiervóór, bldz. 156, noot 1. - Over Baros zie men Bouwstoffen, II, bldz. 257, 272, enz.

3 Stadhouder van den sultan van Ternate op Klein-Ceram. 
Daar beneffens is goedgevonden, en tusschen de generale Compagnie, ende die van Hitoe bescheiden, en besloten, dat yder zyn geloove zal vry houden, en niemand van wederzyden daar inne zal gemolesteerd werden.

Zoo een dienaar van de Compagnie verliep, ende in 't gebied van Hitoe hem verstak, zullen de ingezetenen van Hitoe, op 't verzoek van den Heer Gouverneur, zoodanigen wederom ter hand stellen, gelyk haar luiden overgeleverd zullen werden, die uit de hare by het Kasteel bevonden en weg geloopen zullen wezen.

Eenige dienaars van de Compagnie de ingezetenen van de Compagnie overlast doende, zullen na exigentie van zaken bij den Heer Gouverneur worden gecorrigeerd.

Indien iemand van de onderzaaten van Hitoe de Christenen, 't zy man ofte vrouw, onder het pretext van huwelyk ${ }^{1}$ zonder consent ende voorweten van den Heer Gouverneur tot het Moorendom bragte, zal zoodanige voor de eerste reize verbeuren duizend patoolen, ten profyte van de generale Compagnie, ende zullen de Christenen die eenige Moorse vrouwen van Hitoe halen, zonder consent als voren, in gelyke poene vervallen, en wie bevonden werd voor de tweede reis 't zelve gedaan te hebben, zal zonder genade aan den lyve gestraft werden. Ingevalle de Heer Gouverneur die van Hitoe tot eenige werken, ten dienste van de Compagnie te maken, dede vorderen, zullen zy zonder eenig tegenspreeken daar toe helpen, mits dat die van de Oelisiva's ende Oelilima's te zamen tot zoodanige werken zullen werden geroepen.

Waar tegens de Heer Gouverueur van wegen de Hooge en Mogende Staaten Generaal, zyn Princelyke Excellentie, ende de generale Compagnie, op believen van den Heer Gouverneur Generaal, beloofd heeft, de voorsz. Kakiali als Capitein ende Opperhoofd, mitsgaders alle de andere Orangkaja's, en ingezetenen van Hitoe als haar eige natie tegens alle hare vyanden te water, en te lande te helpen, by te staan ende te defenderen, daar de nood zulks is vereischende, alle welke conditien van dezen contracte bekennen voorsz. Orangkaja's van Hitoe ten aanhooren van alle smalle Hoofden ende hare meeste onderdanen te weezen de oude ende zelve contracten, poincten ende artikelen daarmede van ouds aan de generale Nederlandsche Staat ende Compagnie zijn verbonden, die zy ook belooven getrouwlyk na te komen. Ten oirkonde hebbben dit onder-

1 Vgl. hiervóór, bldz. 155. 
teekend, onderstond op 't Fort van Hitoe dezen 17 Juni' 1633. Was getekend met deze merken ${ }^{1}$.

\section{PERZIË.}

\section{Augustus-September 1633. ${ }^{2}$}

De O. I. C. had in deze dagen in Perzië factorijen te Ispahan, Sjiraas ${ }^{3}$, Lar en Gamron of Bender Abbas. Onderstaand bevelschrift bevestigt den aankoop van een Compagnie's huis in Lar (Vgl. Dagh-Register 1631-1634, bldz. 39, 40, 191, 333; 1636, bldz. 47).

Bevelschrift ${ }^{4}$ wegens het bezit van de huijsinge van Aga Riza Dabulie in de stadt Laar gelegen, door Safie Coelie Chaan, de soone van Jmaan Coelie Chaan, aen den Hollandschen Capiteijn ter wooninge gegeven, verleent op Kelbalie Chaan, regent van Laar, door den coninck Safie d'eerste. Jn de maendt Safar des jaers 1043 overeencomende met de maendt $\ldots{ }^{5}$ des jaers ... ${ }^{5}$ naer Christi geboorte.

${ }^{6}$ Daer is een gebodt van de werelt te gehoorsamen geschiet, namentlijck dit:

Alsoo de Cap $^{n}$ der Hollanderen eerbiedelijck bethoont heeft, dat Safie Coelie Chaan, soone van Jmaan Coelie Chaan, het huijs van Aga Riza Dabulie in het district Lhaar (gelegen) ter wooninge van voorschreven natie gegeven heeft en dat sij aen voorschreven huijs een notabile somme gegasteert ${ }^{7}$ en verbouwt hebbende, deselve althans in het bezit van de Hollandse natie sij [en blijve).

Hierom ist, dat wij ordonneren [en] bevoolen hebben, dat de toevlucht van hooge heerschappie en dapperheijt, sijn hoogheijt de ciraad aen de hooge heerschappije en verhevene fortuijn, Kelbali Chaan, regent van het district Lhaar, voorschreven wooningh aen

1 Volgen eenige Arabische karakters.

2 Uit Contractboek Amsterdam III.

3 Vgl. Heeres, Tasman, p. 57.

- Niet-gelijktijdig "translaet uijt het Persiaens."

5 Niet ingevuld.

"Hiervóór: „L. S. van den coninck Safie d'Eerste."

7 Portug. ngastar" = uitgeven, besteden. 
de Hollandsche natie in het bezit gevende, niet en verhindere datze aldaer resideren, opdat het selve een oorsaeck van haer gemack en tranquilliteijt sij. Dese saeck dan van noodsaeckelijcke aghtervolging erkennende, soo aghte sigh hier aen verplicht te wesen. Geschreven in de maend Safar des jaers $1043^{1}$.

\section{AMBON.}

28 Mei 1634. ${ }^{2}$

In de onrustige dagen, welke de Ambon-eilanden in deze tijden doorleefden, werd Gijsels als gouverneur vervangen door den commissaris Antonie van den Heuvel, die zijn voorganger bij de Hooge Regeering in een ongunstig daglicht had gesteld en thans zelf als zijn opvolger optrad (1634-1635), ofschoon ook hij, volgens het oordeel zijner superieuren, aan "vele menschelijke zwakheden onderworpen" was ${ }^{3}$, zooals

17 Aug.-5 Sept. 1633.

2 Overgenomen uit Valentijn, II (Ambon), b, bldz. '101.

3 Dat een man als Van den Heuvel de leiding kreeg op Ambon en dat nog wel in die troebele tijden, is een raadsel. Geheel de levensloop van dezen ambtenaar der O. I. C. is één aanklacht tegen zijn karakter en beleid. In 1628 komt hij te Batavia, als advocaat-fiscaal, en wordt dáár lid van den Raad van Justitie. Bewindhebbers worden voor hem gewaarschuwd als voor „een snooden guit, wiens kwade streken aan eenige Heeren wel bekend waren." In 1630 wordt hij door den Raad van Indië ter verantwoording geroepen "nopende verscheidene exorbitante schandaleuse injurien en confidente valschheden, zoo van den G.G., als de Raden van Indien gesproken." Hij wordt van zijn ambt gedeporteerd, verzoekt deemoedig om genade, wordt op last van Bewindhebbers in 1632 in zijn ambt hersteld. Hij werd nu in Januari 1633 aangesteld tot commissaris-visitateur voor Ambon, enz., vanwaar hij in October van dat jaar terugkwam. Hij beschuldigde Gijsels van financiëele knoeierijen, enz. Deze bleken later, opgeraapte en valsche beschuldigingen te zijn, maar de Hooge Regeering ontbood Gijsels ter verantwoording en benoemde Van den Heuvel tot zijn opvolger, niettegenstaande G. G. \& R. reeds toen meenden, dat Van den Heuvel meer had gezegd dan hij kon verantwoorden. Deze was dan in Nov. 1633 tot gouverneur van Ambon benoemd en de Hooge Regeering hoopte er alles goeds van, „alhoewel (hij) vele menschelycke defecten ende impertinentien subject is." Gelukkig werd hij reeds in November 1634 door den G.G. teruggeroepen. De motiveering hiervan is teekenend: hij had in zijne betrekking als Commissaris "verscheyde impertinentien gepleecht, compositien gemaeckt ende andere quade gangen gegaen", buitendien zich „in Amboyna bij ons onderdanen door te veel herdicheyt, vreemde bejegeningen ende quaet spreecken vrij wat odieus gemaeckt" en - men had geene juristen genoeg voor den Raad van Justitie te Batavia, waarom Van den Heuvel vice-president van dit college moest worden! Bewindhebbers hebben den G.G. Brouwer en den Raad van Indië ernstig 
ook gedurende zijn gouverneurschap van Ambon bleek. Hij beschouwde den nieuwen kapitein Hitoe, Kakiali, met den stadhouder van Ternate's sultan, als de voornaamste tegenstanders tegen het Nederlandsch gezag: volgens hem zouden deze aanzienlijke inlanders met den sultan van Makassar hebben geconspireert ende aengespannen omme den oorloge tegen ons aen te vanghen, 't lant van Amboina op zijn swackste t' overvallen ende ons en onse christen onderdanen allen mogelijcken afbreuck te doen." Van den Heuvel besloot, te trachten, zich van hen meester te maken, ging in Mei 1634 naar Hitoe, en nam Kakiali met eenige andere hoofden gevangen, „hebbende (hem) een vrundelijck semblant ende een goede mine getoont." Na deze verraderlijke handelwijze deden „den Coninck ende alle de hoofden ende Orangkays van Hitoe" opnieuw "den eedt van getrouwicheyt." Het was slechts schijn, want juist deze gevangenneming zette veel kwaad bloed èn bij Hitoe's bevolking èn bij Ternate's vorst en de zijnen (Vgl. Valentijn, t. a.p., bldz. 100, v.; Tiele-Heeres, Bouwstoffen, II, bldz. LVIII, v., 257, v.; Dagh-Register 1631-1634, bldz. 342).

Eenige Artikelen, welke de Koning van Hitoe ${ }^{1}$, de Orangkaja's ende de inwoonders van 't Land beloofd en gezwooren hebben voor haar, en hare nakomelingen, eeuwiglyk.

\section{ARTIKel 1.}

Alzoo de Koning, van Hitoe, met de Orangkaja's, en het gemeene volk, zekerlyk weten, de quade raadslagen van Capitein Hitoe (anders Kakiali genaamd), als voorgenomen hebbende den staat van de generale Nederlandsche Compagnie te ruineeren, 't land van Amboina, en Hitoe, van de goede vrede te berooven, ende ten verderve te brengen, dat ook eenige Orangkaja's uit vreeze zyne quade practycquen toegestaan hebben, of, haar insuffiçant kennende zulx te beletten, stil hebben gezwegen, zoo is 't, dat de E. Heer

berispt over hunne houding tegenover Gijsels en de benoeming van Van den Heuvel tot gouverneur van Ambon, maar deze verdedigden zich o. a. met de bewering, dat volmaakte personen in Indië niet waren te vinden! In 1636 werd Van den Heuvel wegens laster tegen de Hooge Regeering veroordeeld, om streng te worden gegeeseld en met een priem door de tong gestoken. Op verzoek der Bataviasche predikanten werd hij „van de geeseling geredimeerd, blyvende de verdere inhoud der sententie van kracht." In December van genoemd jaar keerde hij naar patria terug. Wat ik hierboven omtrent hem mededeelde, is geput, behalve uit de Bourstoffen en de DaghRegisters, uit onuitgegeven missives, resoluties ens. uit het Oud.-koloniaal archief, dagteekenende van 1629-1639.

1 De radja van Hitoe, van wien men overigens niets merkt in deze jaren (vgl. hiervóór, bldz. 31, noot 4), wordt hier weder op het tapijt gebracht, nu men hem noodig heeft. 
Gouverneur, Antoni van deu Heuvel, overdenkende 't geen tot de algemeene welstand van nooden is, voorgenomen heeft te breeken deze quade raadslagen, gemelde Capitein Hitoe gevangen te nemen, ter regt te stellen, ende te straffen naar behooren, alzoo hij verbroken ende overtreden heeft het verbod met de Compagnie gemaaakt, en dat ook by hem beloofd, ende bezworen was, op dat alzo het quaad mogte geweerd, ende 't beste verkregen werden, 't welk nodig is tot welstandt van 't land, ende rust van de goede ingezetenen.

Dit al te zamen by den Konink van Hitoe, de Orangkaja's, ende 't gemene volk, aangemerkt zynde, hebben 't voor goed aangenomen, zoekende 't zelve met een opregt herte te vergelden, belyden, ende geven te kennen, dat de Ed. Heer Gouverneur well, ende een goede zaake voor 'tland van Hitoe heeft gedaan; belooven ende zweeren by dezen, dat zy, en alle hare nakomelingen, niemand anders voor haren Heere, ende Hoofd willen erkennen, als den Gouverneur, die door de Heeren Bewindhebberen van de Generale Nederlandsche Compaguie herwaards gezonden word, gelyk zy aan den zelven zweeren eeuwiglyk alle opregtigheid ende trouwe te bewyzen.

ARTIKel 2.

De Konink van Hitoe, en alle de Orangkaja's, nevens alle 't gemeene volk, beloven gehoorzaamlyk naar te komen alle de bevelen van den Ed. Heer Gouverneur, gelyk als de andere Koningen, Orangkaja's, ende ingezetenen van 't land Amboina.

\section{ARTIKEL 3.}

De Konink van Hitoe, neffens de vier Orangkaja's ende de Hoofden van de negryen, zullen met de Heer Gouverneur, ende Orangkaja`s van Amboina, helpen beraadslagen, van 't geene dat nodig is tot welstand van 't gemene land, tot welker einde de Ed. Heer Gouverneur in yder negry een marinjo ${ }^{1}$ of bode zal stellen, die een rotting, met het teken van de Generale Compagnie dragen zal.

ARtTKel 4.

De Konink van Hitoe, de Orangkaja's van 't land, ende 't gemene volk, beloven zoo veel corcorren te maken, ende gereed te houden, als doendelyk zal zyn, ende te panggayen, waar 't de Ed. Heer Gouverneur believen zal, even als de inwoonderen van Amboina.

1 Deze benaming is nog steeds in gebruik (Van Hoèvell, Vocabularium, bldz. 21 ; Ambon, bldz. 23). 


\section{ARTIKel 5.}

Beloven voorders, dat wie vyanden zyn van de Ed. Heer Gouverneur, ook hare vyanden wezen zullen, 't zy dan de Kimelaha, de Ternataanen, 't volk van Lessidi, Cambello, en wie, ofte waar 't zoude mogen wezen, willende de zelve te water, ende te lande vervolgen, ende bevegten, ende de geene welke vrinden zyn van de Ed. Heer Gouverneur, voorstaan, en helpen, even als de inwoonderen van Amboina doen.

Artikel 6.

Beloven ook de Konink van Hitoe, alle de Orangkaja's, ende ingezetenen, geen pitsjaringe te willen houden, ofte gemeenschap te hebben, met des Heeren Gouverneurs vyanden, 't zy van 't land van Loehoe, ofte Cambello.

\section{Artikel 7.}

Beloven ook geen nagelen, moer-nagelen ofte steelen te brengen ofte te verkoopen aan imand anders, als aan de Compagnie, wel verstaande, zuivere ende drooge nagelen, daar voor zy de waardye zullen ontfangen, zoo als aan andere beloofd is, ende indien imand eenige nagelen, moernagelen ofte steelen vervoerd, ende aan anderen verkoopt, 't zy waar 't zoude mogen zyn, zullen 't zelve de Ed. Heer Gouverneur te kennen geven, op dat daar over mogen gestraft werdep.

\section{Artikel 8.}

Alzoo Kakiali voornoemd, veel aan de generale Compagnie schuldig is, zoo beloven zy den Ed. Heer Gouverneur te helpen, ende de nagelaten ${ }^{1}$ goederen van dito aan te wyzen, op dat alle zynen schulden mogen betaald werden.

\section{Artikel 9.}

Indien de Ed. Heer Gouverneur bevind, dat op 't land van Hitoe, eenige onnodige Fortressen, ofte sterkten, zyn, 't zy waar, of hoedanig, de zelve zouden mogen wezen, beloven de zelve af te breken, ende andere te helpen maken, daar 't de Ed. Heer Gouverneur believen, ende goed vinden zal.

Artikel 10.

Alzoo de inwoonderen van 't land Hitoe, haar houden aan de Moorsche Religie, zoo beloofd de Ed. Heer Gouverneur 't haren 
verzoeke, gemelde hare Religie niet uit te roeijen, maar steld in een iders believen, ofte daar by te blyven, ofte de Christelyke Religie aan te nemen, begerende, dat nog de een, nog de ander, daar toe zullen gedwongen, ofte daarom gestraft werden, welke artikelen, alle by de Ed. Heer Gouverneur gesteld zynde, volkomentlyk van de Konink, alle Orangkaja's, ende inwoonders van 't land aangenomen werden, belooven en zweeren met een matacau ${ }^{1}$ (na des lands wyse) ende verklaren voor God, die alles magtig is, mitsgaders voor alle omstanders, die dit contract hebben aangehoord, die ook als waaragtige getuigen daar van. konnen wezen, dat, indien zy dit verbond houden en hare beloften volbrengen, de almagtige Godt haar helpen wil, maar indien zy dit niet naar komen, 't geene zy gezworen hebben, alle ongeluk, dat in de wereld is, haar moet overkomen, ende verderven.

Aldus gedaan, ende besloten, op dat het stand grype, voor ons zelven, en onze nakomelingen eeuwiglyk, tot welker einde wy het teken van onze handen onder dit contract hebbeu gesteld, blyvende zulx zonder eenige veranderinge. Onderstond, Actum op Hitoe in de Logie, dezen 28 Mey 1634. Was getekend 't merk van de J. ${ }^{2}$ Konink van Hitoe, de naamen van Tanahitoemessing, 't merk van P. ${ }^{2}$ Totohatou, de namen van Orangkaja's Baros, en van Pati Toeban. ${ }^{3}$ In kennisse van my was getekend W. van Outhoorn, Secretaris 1634 .

\section{BENGALEN.}

1634 ? 4

Reeds dadelijk na de oprichting der O. I. C. van 1602 werd de handel op Bengalen overwogen (vgl. De Jonge, Opkomst, III, 151, v.; Tiele, Europeërs, VI, bldz. 74), maar tot het vestigen van bepaalde handelsnederzettingen schijnt het niet te zijn gekomen. Misschien, dat de staatkundige toestand de Nederlanders daarvan heeft afgehouden. Wel

1 Bij Valentijn, III, a, (Ambonsche Zaaken van den Godsdienst), bldz. 10, v. vindt men een beschrijving van het matakaoe-drinken in zijne dagen (Vgl. Encyclopaedie, I, bldz. 483). Over de tegenwoordige beteekenis van matakaoe, vgl. men nog Van Hoëvell, Vocabularium, bldz. 22, en Ambon, bldz. 120.

2 Deze letter is mij niet duidelijk.

3 Vgl. noot 2 van bldz. 259.

4 Uit het Contractboek. Het stuk is daar geplaatst tusschen documenten van 1631 en 1632, ten onrechte echter. Zie aan het slot. 
behoorde Bengalen tot het rijk der Grootmogols (het was in 1576 door Akbar den Groote aan zijn rijk gehecht), maar de Portugeezen hadden er vasten voet behouden: zij hadden Hoegli, aan de rivier van dien naam (de Westelijke mondingen van den Ganges), in bezit. Het was de belangrijkste handelsplaats en zoolang deze behoorde aan hunne vijanden, was daar voor de Nederlanders geen gelegenheid, hunne commercie te vestigen. Deze stad nu werd in $1632^{1}$ veroverd door het Mogolrijk en van de Kust van Koromandel uit werden nu door de onzen betrekkingen met „de landen van Bengala" aangeknoopt (Vgl. Dagh-Register 1631-1634, bldz. $241,352,415$; onuitgegeven missives van GG. Brouwer aan Bewindhebbers, 7 Febr., 15 Augustus 1633).

Caull door Hasamchan 2 aen d'Nederlanders verleent, raeckende de handelinge in de landen van Bengala.

Ick, Hasamchan, hebbe gegeven, gelijck geve mits desen, caull aen de Hollandsche Capiteijn ${ }^{3}$, dat zijluijden met hare schepen sullen mogen gaen ende coomen in de landeu van Bengala, alldaer handelen ende negotieren naer hun gelieven, mits dat voor gereghtigheijt van jn ende uijtcomen haerder coopmanschappen sullen betalen 't geene Miercamaffdij Hasie Sjamaell +, jn wiens handen dit cauwell gaet, ende andere coopluijden sullen oordeelen ons daer voor te competeren. Belassten ende beveelen aen alle onse onderdanen principalijck in $\mathbf{0 u g l i j j ~}{ }^{5}$, allwaer zijluijden voorgenomen hebben te resideeren, deselve Holland ${ }^{\text {rs }}$ alle faveur ende vrunschap te bewijsen ende dese ordre in alles te observeeren etc $^{\text {a }}{ }^{6}$.

1 En niet 1633, zooals Danvers, Portuguese, II, p. $247 \mathrm{f}$ en Report, p. $28 \mathrm{f}$, heeft (Vgl. Hunter, Gazetteer, IV, p. 113; Dagh-Register 1631-1634, bldz. 145, $159,195)$.

2 Azim Khan, gouverneur of stadhouder (nabab) van Bengalen, namens den Mogol, van 1632-1637? (Hunter, Gazetteer, II, p. 10).

$s$ Vermoedelijk onze gouverneur op de Kust van Koromandel.

- Blijkbaar tusschen-personen tusschen den gouverneur van Bengalen en den vertegenwoordiger der O. I. C. op de Kust van Koromandel.

${ }^{5}$ Over het belang, dat men voor de O. I. C. in Hoegli zag, vgl. men DaghRegister 1631-1634, bldz. 352. Brouwer dacht, dat de Ganges passage zou verleenen tot "des werelts allervermaerste coopstadt Cathay" (Brouwer aan Bewindhebbers, 15 Augustus 1634).

- Dit kaul is niet gedagteekend, althans niet in dit afschrift. De datum is vermoedelijk te stellen in 1634, immers eerst in de tweede helft van 1632 viel Hoegli den Mogol in handen, wat vermoedelijk eerst in December 1632 den Nederlanders bekend werd (Dagh-Register 1631-1634, bldz. 145). Van vóór dien tijd kan het stuk niet dagteekenen, terwijl Azim Khan ook eerst in dit jaar als gouverneur optreedt. De wijze waarop verder het Dagh-Register 1631-1634 over Hoegli spreekt (bldz. 241, 352) doet mij aarzelen, het kaul te plaatsen vóór 1634 . 


\section{BENGA LEN.}

\section{Augustus 1635. ${ }^{1}$}

Ofschoon handel werd gedreven op Bengalen (vgl. hiervóór, bldz. 267), had de Compagnie dit nog niet gedaan op Hoegli in Juli 1634. Althans in die maand zeggen G. G. \& R., dat zij hadden voorgenomen, „den handel van Bengalen, Pegu, ende Aracan te embrasseeren, maer insonderheijt brenght haere Ed. resolutie mede, een besendinge te doen nae de reviere Ganges, ende vanden handel in Ouglij..... een preuve te nemen....." In hetzelfde jaar dan werd een jacht naar Hoegli gezonden. G. G. \& R. hadden groote verwachtingen van den handel dáár, als punt van uitgang langs den Ganges. Maar vlotten wilde de commercie daar voorloopig niet ten gevolge van de "vexatie" der Mooren en de mededinging van Engelschen en van Portugeezen, welke laatsten dáár waren blijven handelen (Vgl. Dagh-Register 1631-1634, bldz. 352, v., 415, 445; Dagh-Register 1636 bldz. 26, 123; onuitgegeven Generale Missive, 4 Januari 1636).

De O. I. C. trachtte nu, den Grootmogol zelven in hun belang te winnen en hut gelukte den onderkoopman François Timmers, ${ }^{2}$ welke in die dagen te Agra onze belangen behartigde, met behulp van een aanzienlijk ambtenaar van den Mogol (zie beneden, blz. 269), onderstaanden ferman te verkrijgen (Dagh-Register 1636, bldz. 51, 114, 123).

Firman door den sullthan Choron ${ }^{3}$ aen d'onse in Agra verleent aengaende den vrijen handell in Bengala.

Godt is de grootste, daer naer Aghabaar ${ }^{4}$. Assalam Chan, 5

Die daer zijt een saijet ${ }^{6}$, welcke is de zuijverste ordre van Mohomet, niet staende naer eere ende rijckendommen maer ijverigh

1 Uit het Contractboek. - Is daarin verkeerdelijk geplaatst op 1637.

2 Reden voor mij, om dit stuk, dat eigenlijk niet in deze verzameling te huis behoort, toch daarin op te nemen: immers het is door een Nederlander ten behoeve der O. I. C. ngeprocureert."

3 "De Choron (een eigennaam) off groote Mogor" (Dagh-Register 1636, bldz. 123). De Mogol, die dezen ferman uitvaardigde, is sjah Jahan of Jehan, 1628-1658 (Hunter, Gazetteer, IV, 349). In zijn tijd werd de residentie van het rijk weer verplaatst naar Delhi (Hunter, Gazetteer, III, 89; IV, 342; I, 48).

4 Akbar de Groote (1556-1605).

5 Volgens Hunter, Gazetteer, II, bldz. 10, was in 1635 Azim Khan nog gouverneur, en werd deze in 1637 opgevolgd door Islam Khan, welks naam beter overeenkomt met "Assalam Chan". Toch zijn zoowel de datum aan het slot als de omstandigheden, waaronder de ferman is gegeven, voor mij zoovele motieven, om het stuk te plaatsen op 1635. Vergist Hunter zich missehien in dit jaartal? Vgl. óók beneden, bij latere fermans.

6. Sajjid: een Arabische geboorte-adel-titel, waarmeè een deel der afstammelingen van Mohammed's dochter Fâtimah wordt aangeduid. 
in den dienst Godes, een pilaer van mijn rijck, onder alle mijne vrunden de grootste, tot wien alltijt mijn hert seer genegen is geweesst, ende gehouden als mijn aengenoom zoon etc ${ }^{\mathrm{a}}$.

Uijt schrijven van Masell Moluch Meijnt Mirmosa ${ }^{1}$ hebbe verstaen dat den vorigen gouvern ${ }^{\mathbf{r}}$ van Bengala met toedoen van de Portugesen de Hollanders, daervan eenige ziek waren, veell moeijte aengedaen ende haer schut aengehouden heefft. ${ }^{3}$ Warom is dit geschiet? De Hollanảers zijn groote cooplieden ende comen onder onse schaduwe handelen; dies begeeren, dat met hare schepen in Onglij ende alle de havens sorterende onder Bengala vrij mogen comen ende onverhindert haren handell drijven, mits betalende behoorlijcke toll. Dit is mijn woordt; t'selve sullt houden ende well toesien, dat van niemandt haer eenigh verdriet offte gewellt aen gedaen werde. Hoe aen haer meerder goedt doet, hoe onse vrundtschap grooter zall werden.

Actum in Agra den $16^{\mathrm{e}}$ dagh der maendt Soffer jnt jaer van Mahamet $1045 *$ ende onses rijex $8 .^{5}$

Boven stondt Conings zeegell.

Onder :

Dara Seeckouw, ${ }^{6}$ soon van den Coningh, ende zijn zeegell.

$$
\text { Nogh lager }
$$

Affelchan, duiwan, ${ }^{7}$ onse secretaris.

1 In die dagen gouverneur voor den Mogol van „Cambaija, Brootcha, Balsaar ende Ourpaar", allen gelegen in het tegenwoordige Guzerat, nl. Kambaja (Cambay), Broach, Bulsar (Dagh-Register 1636, bldz. 49, 50). Hij was Gouverneur van Surat geweest.

${ }^{2}$ Azim Khan???

3 Vgl. nog Dagh-Register 1636, bldz. 122.

4 Den $16^{\text {den }}$ Safar 1045 is 1 Augustus 1635.

5 Jehan kwam op den troon in 1628: dus kan het $8^{\text {sto }}$ jaar zijner regeering vallen in 1635. Het negende viel in 1636 (Zie Dagh-Register 1637, bldz. 106, 245).

${ }^{6}$ De oudste zoon van shah Jehan. Hij werd in 1659 vermoord door zijn jongeren broeder, den bekenden Aurengzeb (Hunter, Gazetteer, IV, 349, 352), die met geweld zich een weg tot den troon baande (Talboys Wheeler, Early records, p. $12 \mathrm{ff}$, Valentijn, IV, 2, Mogols, bldz.'230).

7 Dewaun, divan: hier = „des coninck cancelier" (Vgl. Dagh-Register 1637, bldz. 246). 


\section{BANDJERMASIN.}

4 September 1635. ${ }^{1}$

Reeds in de eerste jaren der $17^{\text {de }}$ eeuw is sprake van betrekkingen tusschen de O.I. C. en Bandjermasin, maar zij waren veelal van vijandelijken, althans min vriendelijken, aard. In 1612 werd de hoofdplaats Bandjermasin door de onzen verwoest. Een tiental jaren later worden nieuwe betrekkingen aangeknoopt, vooral met het oog op den peperhandel. Toch waren de relaties niet van duurzamen aard. Maar sedert ongeveer 1631 is daarvan in meer dan gewone mate sprake: de vorst van genoemd rijk, bevreesd voor de machtsuitbreiding van Mataram, tracht met de onzen op beteren voet te komen, maar van de gehoopte handelsvoordeelen - vooral het pepermonopolie - kwam door 's Vorsten dubbelzinnige houding niet. Onderhandelingen bleven voortduren, totdat in Juli 1635 een gezant te Batavia verscheen, met wien het onderstaand verdrag werd gesloten, dat, naar men hoopte, voor de toekomst de verhoudingen zoude regelen (Zie vooral Van Dijk, Borneo, bldz. 1-26. Het daar afgedrukte contract is gecopieerd naar een ander exemplaar dan het hier volgende. Vgl. ook Dagh-Register 1631-1634, passim; deze Bijdragen, III, bldz. 263-288; Kronïk Historisch Genootschap, IX, bldz. 252, vv.).

Contract wegens d'E. Comp ${ }^{\mathrm{e}}$ met die van Martapoura gemaeckt.

Jck Retna Dij Ratja, alias Godia Babouw ${ }^{2}$, sabandar des conings van Banjarmarsingh, in Martapoura, ${ }^{3}$ expresselijck als ambassadeur door Zijue Maijt affgesonden van Maŕtapoura naer $B^{a}$, omme aen den $\mathrm{H}^{\text {re }}$ Gouvern ${ }^{\mathrm{r}}$ Gener ${ }^{\mathrm{l}}$, ende Rade van Jndien daer residerende, van wegen zijne Maij ${ }^{t}$ te belooven om merckelijcke redenen, datter egene peper in de landen van Banjarmarsingh en zall verkoght, veell min uijtgevoerdt werden ${ }^{4}$, zoo lange als gemelte $\mathrm{H}^{\text {ren }}$ Staten Gener $^{1}$ ende Raden van Jndien eenige Nederlanders tot Martapoura aen landt sullen houdeu offte dat daer offte tot Banjarmarsingh 5 eenigh schip, jaght, fregat offte chialoup van de wellgem ${ }^{\text {te }} \mathrm{H}^{\text {ren }}$ Staten Gener $^{1}$ ende Raden van Jndien moghten wesen, bekenne mits desen op 't versoek van mijnen coninck ende voor deselffs rekeninge te borge ende op leveringe van peper well ende tot miju vergenoegingh ontfangen te hebben uijt handen van Bencon, overste der Bata-

1 Uit het Contractboek.

${ }^{2} \mathrm{Hij}$ was een Guzerat van geboorte (Van Dijk, Borneo, bldz. 23, noot 2).

${ }^{3}$ Hier was de zetel der regeering, na de verwoesting der vroegere hoofdplaats door de onzen in 1612 .

- Van Dijk, Borneo, dldz. 25, heeft hier nog de woorden : „aan of bij eenige vreemde natiën, hoedanig die ook mogten wezen".

${ }^{5}$ De verlaten hoofdplaats. 
vische Chinesen, ende Jancongh, Chienees coopman, in pitjens ${ }^{1}$ offte Javans gelt de waerde van drie duijsent $R^{a}$ van $8^{\text {ten }}$, die daervooren hadde ${ }^{2}$ betalinge van den Nederlandschen directeur generaell ${ }^{3}$ ontfangen sullen, welcke somme van drie duijsent $R^{\mathrm{a}}$ van $8^{\text {ten }} \mathrm{jck}$, Retna dij Ratija, alias Godja Babouw, beloove uijt den naem van myuen coninck voornoemt, als van hem daer toe geauthoriseerdt zijnde, te doen betalen aen de gecommitteerden van de Nederlandtsche Oosstjudische Comp ${ }^{e}$ in Martapura resideerende, met de eerste peper van dit jegenwoordige saysoen off mouson, in dese maendt September ende d'aenvolgende maent October rijp vallende, ende dat tegen den geaccordeerden ende vast geraemden prijs voor jegenwoordigh ende toecomende van vijff $\mathrm{R}^{\mathrm{a}}$ van $8^{\text {ten }}$ 't picoll offte de 35 Martapourse gantangs, bedragende dese schulldt van $3000 \mathrm{R}^{\mathrm{a}} 600$ picolls peper. Alles onder expresse conditie ende verbandt hier vooren gemelt, dat den geseijden mijnen koninck volgens zijne solemnele belofften aen niemandt anders als die van de Nederlandsche Oosstjndische Comp ${ }^{\mathrm{e}}$ uijt zijn landt ende onder zijn gebiedt peper sall verkopen, laten verkoopen nogh vervoeren, soo lange de voorschreven Comp ${ }^{\text {e }}$ volck, schip offte jaght tot Banjarmarsingh zij hebbende. Des sall ick ondergeschreven de geseijde pitjens ende de vordere coopmansschappen, voor rekeninge van mijne koninck alhier opgekoght, vermogen te laden in des Comps schip off schepen, omme deselffe toll ende vraghtvrij in Martapoura over te voeren ende aen meer gemelten mijnen koninck alldaer te behandigen offte omme zijnè ordre daermede naer te comen. Jn teeken der waerheijdt ende omme dit contract te volldoen hebbe dit geschrifft met mijnen naem ende gewoonlijcke hantteeken ondergeschreven.

Actum jnt casteell Bat ${ }^{\mathrm{a}}$ desen $4^{\mathrm{e}}$ September $\mathrm{A}^{\circ} 1635$. Onderstondt : jn kennisse van ons, was geteekent Henrick Brouwer ${ }^{4}$, Anthonio van Diemen ${ }^{4}$, Jan van der Burgh ${ }^{4}$, Steven Barentszoon ${ }^{5}$.

${ }_{1}{ }_{\text {} 10}$ Bantamze pitjens doen 1 stuiv.; zynde de eenigste kopere munt hier.

Op Java heeft men nog een soort pitjens, van welke 'er 50, aan een strootje geregen zijnde, een dubbeltje doen...." (Valentijn, IV , 1, Batavia, bldz. 356). - "Pitjens, synde seeckere gegaette munte, onder d'Indianen deser quartieren getrocken" (Van der Chijs, Plakaatboek, I, bldz. 445).

2 Van Dijk: "hunne".

${ }^{3}$ Zooals men weet, in die dagen de tweede persoon in Rade van Indië, onmiddelijk volgende in rang op den GG., vooral belast met de handelsaangelegenheden (Vgl. Heeres in Encyclopaedie, II, bldz. 71, v.v.).

4 G.G. en verdere leden van den Raad van Indië (Vgl. Dagh-Register, 1631-1634, bldz. 168, 370).

${ }^{5}$ Deze was in 1634 en 1635 als gezant naar Martapoera geweest en met hern was de gezant van Martapoera te Batavia gekomen (Van Dijk, Borneo, bldz. 23). 


\section{FORMOSA.}

18 December 1635. ${ }^{1}$

Nadat de onzen zich in 1624 (vgl. hiervóór, bldz. 195, v.v., 214) op Formosa hadden gevestigd, kwamen zij al spoedig in nadere aanraking met de "dorpen ende vlecken omtrent onse begrepen stadt". Zij kwamen o. a. in vriendschappelijke verhouding tot Mattau, een plaats van beteekenis, daar zij „konde uijtmaecken omtrent 2000 weerbare mannen (Dagh-Register 1624-1629, bldz. 145). Later veranderde deze vriendschappelijke betrekking in een vijandelijke. Reeds in 1628 werd door sommige dorpen, o. a. Mattau, ,groote moedwil" gepleegd tegen de onzen, waaraan echter de houding van den gouverneur Nuyts niet vreemd schijnt te zijn geweest (Onuitgegeven missives van Nuyts 3 Nov. 1628, van den predikant Candidius, 20 Aug. 1628, van G. G. \& R. aan Bewindhebbers, $10 \mathrm{Febr}$. 1629). In 1629 werden 50 soldaten, door Nuyts naar Mattau gezonden, om Chineesche roovers, die zich aan land hadden begeven, te "attrapeeren", allen door de inlanders o. a. van Mattau vermoord, dank ook eigen onvoorzichtigheid (Onuitgegeven missives aan Bewindhebbers, van G. G. \& R. 15 Dec. 1629, van Van Diemen, 5 Juni 1631). Althans in Maart 1631 zijn de Nederlanders van plan, „een exploict op die van Mattau te doen" (Dagh-Register 1631-1634, bldz. 8). Oók (nog?) in April 1634 waren de verhoudingen niet van de beste en wel uit oorzaak van "de moordadige acte tegen ons voor desen gepleecht" (bldz. 284): „het enorme faict ende massacre van die van Mattauw". "De voorgenomen wraeck" hierover werd toen nog uitgesteld, o. a. wegens gebrek aan voldoende macht, niettegenstaande de bewoners, „vilipenderende ons gesach ende respect in Taijowan," ons geen hulp hadden willen verleenen, zelf niet "op onse gedane insinuatie" bij een expeditie tegen een ander gedeelte van het gouvernement Formosa (bldz. 307). Den 23 November 1635 , nadat versterking uit Batavia was gekomen, vond een expeditie tegen Mattau plaats: de woningen werden in den asch gelegd, nadat het "vleck" was genomen, „met weijnige resistentie". De onderwerping volgde spoedig daags onder de voorwaarden, in onderstaand contract neergelegd (Dagh-Register 1636, bldz. 19-21, waar 't contract is afgedrukt; Kronijk Historisch Genootschap, IX, bldz. 256, v.v., waar ook de overeenkomst voorkomt; onuitgegeven missives aan Bewindhebbers, van Brouwer, 4 Maart 1634, van G. G. \& R., 4 Jan. 1636 en 28 Dec. 1636; Grothe, Archief, III, bldz. 36, v.v., vooral bldz. 89-95).

Accoordt getroffen tusschen d'E. H $\mathrm{H}^{\mathrm{re}}$ gouvern ${ }^{\mathrm{r}}$ Hans Puttmans en den Raedt van 't comptoir Taijoan wegens de Nederlandtsche Vereenighde Geoctroijeerde Oostindische Comp ${ }^{e}$ ter eenre ende de gecommitteerde oversten van 't groote dorp Mattauw ${ }^{2}$ wegens de gantsche gemeijnte van het voornoemde dorp ter andere zijde.

1 Uit het Contractboek.

2 Het lag vermoedelijk aan de Westkust van het eiland. Op Valentijns kaart van Formosa (in deel IV, 2) komt een Mattamir-rivier voor: misschien een drukfout voor Mattauw-rivier. 
Eerstelijck belooven wij, Funchsin, Tavoris, Titulogh ende Tijdaros, ${ }^{1}$ uijt den naem ende van wegen de gantsche gemeijnte van ons dorp Mattouw, dat wij alle de hooffden ende andere gebeente van de massacreerde Hollanders ${ }^{2}$, die wij volgens onse costuijmen te pronck plagten te dragen ende nogh bij ons moghten berusten, door het gantse dorp onder een ijder sullen doen op samelen ende wederom met d'eerste gelegenth ${ }^{t}$ in Sinckan aen $d^{0}$ Junij ${ }^{3}$ leveren, mitsgaders alle de musquetten en het vordere geweer als kleedinge, soo ende sulx alst selve onder ons zoude mogen bevonden worden.

Ten anderen zoo geven wij met deese overgeleverde clappus en pinangh boomkens in eerde geplant ${ }^{4}$ te verstaen, dat wij transporteeren ende opdragen volcomentlijck ende in allen deelen aen de Hoge Mogende $\mathrm{H}^{\text {ren }}$ Staten Generaell vande Vereenighde Geunieerde Nederlandsche Comp ${ }^{\mathrm{e}}$ allsulcken pretensien ende eijgendommen, als wij wegens onse voorouders ende het besitt, dat wij jegenwoordigh int dorp Mattouw ende te plaetse daer landt ${ }^{5}$ omtrent gelegen, zijn hebbende, zoo verre als onse jurisdictie naer 't Oosten tot aent geberghte, Westen tot aen de zee ende het Noorden ende Zuijden zoo verre als ons commandement is streckende, zouden mogen geerfft offte dus langhe in eijgendom doort besitt volgens aller volckeren reght verkregen hebben. ${ }^{6}$

Ten $3^{\mathrm{e}}$ dat wij om geenigerhande oorsaeken naer desen meer eenige wapenen tegen die Hollandsche natie, hare bondtgenooten offte geallieerde vrunden bij der handt zullen nemen, maer ter contrarie bovengem ${ }^{\text {te }}$ Hooge Mogende $\mathrm{H}^{\text {ren }}$ Staten Gener ${ }^{1}$ erkennen, respecteeren, gehoorsamen ende houden voor onse beschermheeren, onder wien wij ons gaerne ende gewillighlijck submitteren, tot welcken eijnde ende op dat alles met des te beter ordre soude mogen toe-

1 In 't Dagh-Register: Tavoris, Tuncksuij, Titulogh ende Tidaros.

2 Dagh-Register en Kronïk: "Nederlanders".

${ }^{3}$ Robertus Junius was predikant op Formosa van 1629-1643, o. a. te Sinkan (C. A. L. van Troostenurg de Bruyn, Biographisch Woordenboek, bldz. 220, v.; vgl. Dagh-Register 1636, bldz. 19).

${ }^{4}$ "Dat haer lant ons souden opdraegen end dat betoenen soude, met pijnangende clappers-boomties, van haer eigen aerde in scuttels geset, voor de voeten" van den Gouverneur te brengen (Grothe, Archief, bldz. 91).

${ }^{5}$ Het Dagh-Register en Kronijk hebben: „ende ten platten lande daer omtrent gelegen".

${ }^{6}$ Het Westersch karakter der overeenkomst loochent zich hier zeker niet. „De articulen.... wirden haer voorgeleesen in Duits, in Chineess end van ons in Sincans, wijtloopig met de verclaringe van dien haer vorgestelt" (Grothe, Archief, III, bldz. 94).

$7^{\circ}$ Volgr. III. 
gaen, belooven wij mede te gehoorsamen ende naer te comen alle 't geene ons die vier overhooffden, ${ }^{1}$ die d'E. $\mathrm{H}^{\mathrm{r}}$ Gouvern $^{\mathrm{r}}$ zall gelieven daertoe uijt een dubbell getall, van onse ouste te committeeren, te stellen, in billichh ${ }^{t}$ gelassten, commanderen ende beveelen. Jtem dat geduriglijck een prince flaggetien op een van ons vier principale kercken $^{2}$ drie maenden om drie maenden sullen laten waijen, allwaer ook, soo der ijets remarcabels voorvallt, sulx dat onse opperhooffden ende outsten vant dorp mosten te samen coomen, de vergaderinge zullen houden.

Ten vierde dat, zoo wanneer d'E. $\mathrm{H}^{\mathrm{r}}$ Gouvern ${ }^{\mathrm{r}}$ met eenige andere dorpen offte jnwoonders deses landts compt in oorlooge te vervallen, ons alltijt willigh ende bereijdt sullen laten vinden om deselve nevens de Hollandtsche ${ }^{3}$ te beoorlogen ende vermeesteren, waertegens de Hollandtsche natie ${ }^{3}$ weder, mits dat den oorloge in redenen bestaet ende den selve met kennisse van d'E. $\mathrm{H}^{\mathrm{r}}$ Gouvern ${ }^{\mathrm{r}}$ wert besloten bij der handt te nemen, zall gehouden wezen ons naer vermogen in aller billickh ${ }^{t}$ te assisteren ende hellpen, voor zooveell des Comp ${ }^{8}$ constitutie will toelaten.

Teu vijffden dat wij alle Chineesen, die jn Wancken ${ }^{4}$ offte elders calcbranden als die het platte landt, om hare negotie jn hertevellen als anders texerceren, noodwendigh te ${ }^{5}$ gebruijken, vrijelijck ende zonder eenige verhinderinge offte overlast hun aen te doen, over alle ${ }^{6}$ sullen laten passeren ende repasseren, daer ende ter plaetse daer 't hun geliefft, sonder noghtans eenige Chineese roovers, verloopene Hollanders ${ }^{7}$ offte hunne slaven op te houden

1 Als zoodanig werden erkend de vier aan 't hoofd der overeenkomst genoemde hoofden: „Is haer elck een frouwelen rok vereert, dien sij souden draegen, een princenvlagge, end een stok, daerse met souden gaen, dat betekenen soude, dat beveelhebbers waeren, wijtloopig het beduitsel van het voorige haer explicerende" (Grothe, Archief, III, bldz. 95).

2 Het zendingswerk had op Formosa reeds in deze eerste jaren eenige beteekenis gekregen (Vgl. ook Van Toorenenbergen, Zending Formosa, in De Gids, 1892, III, bldz. 31 vv.). Maar op welke plaatsen in die dagen deze vier "principale kercken" stonden, is mij niet bekend: in onze hoofdplaats (Zeelandia) werd gepreekt, te Sinkan stond een kerk (Grothe, Archief, III, bldz. 64, 73 v.v., 94). Misschien ook te Tavacan (t. a. p., bldz. 133).

s Dagh-Register en Kronïk: "Nederlandsche natie."

“ Bij Valentijn een „Canaal van Wanckan" bij de Mattamir-rivier (Vgl. Grothe, Archief, III, bldz. 63).

${ }^{5}$ Dagh-Register en Kronïk: "moeten gebruijcken."

"Dagh-Register en Kronijk: "overal."

7 Dagh-Register en Kronijk: "Nederlanders." 
offte huijsvesstinge te verleenen, maer ter contrarie datelijck naer gedane requisitie d'sellve sullen weder geven offte selffs aen 't Casteell 1 brenghen.

Ten sesden dat zoo wanneer ons den princestock bij den deurwaerder, t'zij aen ijmandt particulier offte wel een meerder getall, vertoont ende ons aengeseght wordt, datelijck in Sinckan offte aen het Cassteell om eenige saeke te verantwoorden offte well andersints gebruijckt te werden, te compareeren, t' sellve datelijck sal naercomen ende obedieeren.

Ten sevende ende jonghsten dat wij, tot erkentenisse van onse misdaet int masacreeren van de Hollanders ${ }^{2}$ begaen, op den zelven dagh dat sulx geschiet is, alle jaeren een groote sogh ende beijer ${ }^{3}$ aent fort bij $\mathrm{d}^{\prime} \mathrm{H}^{\mathrm{r}}$ Gouvern $^{\mathrm{r}}$ sullen brengen, waervoor zijn E. tot onderhoudinge van vrundtschap ons weder zall vereeren met 4 princen vaendellkens. Jnt fordt Zeelandia adij $18^{\mathrm{e}}$ December $\mathrm{A}^{0}$ 1635. 4 Onderstont Hans Puttmans.

\section{FORMOSA.}

\section{Februari 1636. ${ }^{5}$}

Na de onderwerping van Mattau, enz. (zie hiervóór, bldz. 272 v.v.) ging Putmans voort met op te treden tegen andere dorpen, met wie wij overhoop lagen. Zoo werd opgetrokken tegen Takarejan of „de Takareiansche dorpen" („sijnde gelegen 12 a 13 mijlen zuijt oost van Taijouan te landewaerts") ${ }^{6}$, dat in 't begin van 1636 in onderwerping kwam met de verdere ${ }_{n}$ dorpen Tamsuij, Tapoeliangh, ende Sataliouw" $\ldots{ }^{7}{ }_{n}$ medebrengende 17 levendige varckens tot een teecken ende leetwesen van haere gepleechde quade acten." (Vgl. Grothe, Archief, III, bldz. 95, v.v.; Dagh-Register 1636 , bldz. 21, v., 75, 286, v.). „De articulen van den E. H. Gouverneur haer voorgestelt, waeren dese, in korte uytgetrokken":

1. Dat haer landt end den eigendom van dien mosten overgeven aen de Ho. Mo. Heeren Staten, end tot teken van dien clappes

1 Zeelandia.

2 Dagh-Register en Kronïk: "Nederlanders."

$s$ Een zeug en een beer.

4 Niet alleen Mattau, maar ook enkele andere dorpen onderwierpen zich in deze dagen. O. a. worden genoemd Toelang, Bakaloang (Grothe, Archief, II, bldz. 86, v.v., 103).

5 Overgenomen uit Grothe, Archief, III, bldz. 105.

6 Vgl. over de ligging van verschillende dorpen, Grothe, t. a. p., bldz. 106, 113, enz. Het hier bedoelde Tamsuij ligt aan de Z.W.kust van het eiland, aan de rivier van dien naam.

7 Vergelijk nog Grothe, t. a. p., bldz. 108, v.v. 
end pynang boomtjes, in haere aerde gezet, mosten ant Casteel brengen.

2. Dat de waepenen niet meer tegen de onse mosten voeren.

3. Dat op den dach, als alle onse bontgenoeten end vrienden verscijnen souden, sij dan mede verscinen mosten.

4. Dat [zij] geen Chineesen souden overlast doen.

5. Dat, soo sulx versoeken, met ons sullen gaen oorlogen.

6. Dat als den princen stok om haer quam, dan dienen te verscijnen.

\section{SURAT.}

$1636 ? 1$

Toen de Nederlanders in het Oosten verschenen, was de machtigste staat van Vóór-Indië het Mohammedaansche rijk der Grootmogols. Het stond toen onder het roemvol bestuur van Akbar den Groote (1556-1605). Onder de laatste jaren der regeering van dien Vorst kwamen de onzen in een zijner havens. Het toen krachtig bestuurde rijk strekte zich (ten gevolge der aanhechting daaraan van verschillende Hindoe- en Mohammedaansche staten) in die dagen uit over geheel Hindostan, Bengalen inbegrepen. Guzerat in het Oosten, Orissa in het Westen, vormden aan de Arabische Zee en de Golf van Bengalen de verst verwijderde deelen van Akbar's staat. Zijne pogingen om ook Dekkan (dus Vóór-Indië bezuiden de Tapti en het Windhya-gebergte en bezuiden de Godaweri) aan zijn rijk te voegen, hadden geen voldoend sucees, al waren zij niet geheel zonder resultaat gebleven: Berar, Khandesh en Ahmednagar werden door Akbar tot zijn rijk gerekend, al was de verhouding van ondergeschiktheid niet overal gelijk, soms min of meer nominaal. In het verdere Dekkan dan bleven verschillende rijken bestaan, voorloopig onafhankelijk van de Grootmogols (Hunter, Gazetteer, passim; Gribble, Deccan, passim, enz.) rijken, met verschillende waarvan de O. I. C. in de eerste jaren der $17^{\text {de }}$ eeuw almede in aanraking is gekomen (Vgl. de contracten onder de Kust van Malabaar en de Kust van Koromandel, enz.).

In 1602 verschenen voor het eerst Nederlanders in Akbar's rijk, en wel van Atjeh uit. Daar toch waren in Augustus 1601 verschenen twee Zeeuwsche schepen, wier leiders het gelukte, de vijandelijke verhouding tusschen de Nederlanders en den Sultan (vgl. hiervóór, bldz. 19 jo ${ }^{48}$ ) in een vriendelijke te wijzigen; bij welke gelegenheid ook Frederik de

I Overgenomen uit Dagh-Register 1636, bldz. 113.

De fermans werden 3 Maart 1636 aan den opperkoopman te Surat, Barend Pietersen, medegedeeld door den gouverneur van Surat, namens den Grootmogol: zij moeten dus van iets vroeger dagteekenen. 
Houtman zijne vrijheid herkreeg. Een factorij, Zeeland genaamd, werd opgericht en eenige Nederlanders dáár achtergelaten. Twee van hen, Hans de Wolff en Lafer, gingen in het begin van 1602 op inlandsche schepen naar de Westkust van Vóór-Indië en kwamen bij Surat aan de Tapti, een zeer belangrijk handelscentrum, waar óók inlandscheschepen uit den Maleischen Archipel kwamen handeldrijven. De stad werd namens den Grootmogol door een "gouverneur" bestuurd. De Nederlanders werden goed ontvangen: ${ }_{\text {de }}$ ingeseetenen en beweesen ons geen cleyne vrientschap, cregen stracks een huys met hetgene ons van noode was...." Op het punt naar Atjeh terug te keeren, werden zij door Akbar naar zijn Hof opontboden.

Deze eerste Nederlanders, welke Surat bezochten, hadden goede hoop op het drijven dáár in de toekomst van een winstgevenden handel: „want hier proffijt te doen is", en raadden dan ook zeer beslist aan tot het voortzetten dezer commercie met onze eigen schepen (Vgl. Tiele, Europeërs, VI, bldz. 43 v. v.; De Jonge, Opkomst, II, bldz. 256, 495, v.; Hunter, Gazetteer, VIII, p. 477 f). Hun optreden is dan ook het begin geweest onzer zoo belangrijke vestiging in Surat, hetwelk (zij het dan na allerlei lotwisselingen) een punt van uitgang werd voor onze handelsbetrekkingen met Hindostan, dat, na ons optreden in Bengalen (hiervóór $n^{\circ} \mathrm{CX}$ enz.) dus langs twee wegen door onze kooplieden werd bezocht. De O. I. C. van 1602 toch heeft dadelijk na haar optreden Surat weder doen bezoeken (1604) en vermoedelijk is toen reeds een factorij harentwege dáár opgericht. In elk geval, in 1607 bestond er één onder leiding van David van Deynsen. Maar de geschiedenis er van was in den eersten tijd een droevige: de leider der factorij werd gevangen genomen en kwam om, hare goederen werden gestolen, enz. Bij deze feiten kwamen vooral twee factoren aan den dag: het stoken der Portugeezen, welke de komst der Nederlanders dáár zeer ongaarne zagen en de knevelarijen van den Gouverneur en verdere inlanders. Vooral met den laatstgenoemden factor hebben de onzen rekening moeten houden (De Jonge, Opkomst, III, bldz. 34, v.). In de eerste jaren was de verhouding ongunstig (Mijer, Instructiën, bldz. 19) en het zou geruimen tijd duren, vóór van een geregelden handel van Nederlandsche schepen op Surat sprake is. Vooral aan Coen, Pieter van den Broecke en Pieter Gilliszoon van Ravesteyn is het te danken, dat de aandacht op deze belangrijke plaats gevestigd bleef. In de eerste plaats aan Van den Broecke. Den 2 Augustus 1616 , op zijn terugkomst van zijn bekenden tocht naar Arabië (vgl. hiervóór, bldz. 136), deed deze wakkere pionier Surat aan. Door den Gouverneur en andere aanzienlijken goed ontvangen, kreeg hij de „belofte van te mogen blijven." Maar de daar gevestigde Engelschen begonnen tegen de onzen te intrigeeren en het kostte Van den Broecke moeite genoeg, om de toezegging door den Gouverneur te doen gestand houden. 't Schijnt, dat zijne bedreiging, represailles te zullen nemen voor de behandeling Van Deynsen aangedaan, eenigen indruk maakte. „Hij verkreeg althans verlof, „coomanschappen met volck" te Surat te laten tot de beslissing van den Mogol te Surat zoude zijn gekomen, waarachter de Gouverneur zich thans verschool. Van den Broecke huurde een huis en liet, toen hij den 9 September vertrok onder groote eerbewijzen van de inlandsche autoriteiten, vier Nederlanders achter onder leiding van 
den onderkoopman Wouter Heuten of Heute ${ }^{1}$, in 1617 vervangen door den opperkoopman P. Gz. van Ravesteyn. Dat de handel van beteekenis werd geacht (opgekocht werden salpeter, indigo, opium, maar vooral „allerhande kleeden", in de eerste plaats voor den Maleischen Archipel en daardoor "de siele vant groote lichaam" van 's Compagnie's commercie; terwijl door ons aan de markt werden gebracht o.a. muskaatnoten, kruidnagelen, enz.), blijkt wel hieruit, dat den 15 Juni 1620 Van den Broecke door Coen werd benoemd tot "Overhooft over de negotie in Mocha en Suratte" (Vgl. hiervóór, bldz. 183). Na omzwervingen langs Arabië's kust, enz. kwam hij den 4 Oetober 1620 te Surat, om daar "voor Commandor en Directeur te liggen." Hij bekleedde die betrekking tot 2 December 1628 en werd opgevolgd door Jan van Hasel, die stierf 4 Augustus 1632 en vervangen werd door Jacob van der Graeff (Onuitgegeven ress. der Heeren XVII, Aug. 1617, 26 Nov. 1619, 16 Maart 1620 ; ms. en gedrukt journaal van Pieter van den Broecke, enz.). Behalve in Surat zelf, waar de hoofdfactorij was gevestigd, dreven wij in de jaren, welke verliepen vóór het verleenen van onderstaande fermans, handel te, hadden tenminste betrekkingen aangeknoopt met verschillende plaatsen, welke factorijen wel niet altijd door in stand werden gehouden, maar toch in deze jaren veelal de centra voor onzen Hindostanschen handel bleven: Broach, Baroda, Cambay, Ahmadabad, Burhampoer, Agra, Dsjalalpoer, enz. Met de bovengenoemde moeilijkheden (concurrentie van andere Europeanen, allerlei vexaties der inlandsche autoriteiten, het monopoliseeren door hen van sommige handelsartikelen, enz.) bleven wij kampen en niet altijd ging het gemakkelijk, de moeilijkheden te boven te komen. Onderstaande fermans geven een blik op de positie der onzen in het rijk van den Grootmogol (Vgl. Dagh-Registers 1624-1629, 1631-1634, 1636, passim; onuitgegeven journaal van den commissaris Dirk van der Lee 1627-1628, onuitgegeven missive van Hendrik Brouwer aan Bewindhebbers, $15 \mathrm{Aug}$. 1634, enz.). Ook reeds vroeger waren verschillende fermans van vrijen handel, vrijdom van tollen, enz. door den Grootmogol aan den onzen verleend, maar, ofschoon ik weet, dat zij verleend zijn, trof ik hen niet in extenso aan.

Hoe sijne $\mathrm{Maj}^{\mathrm{t}}$ niet en begeert, ende seer hooch op sijn ongenade verbiet, dat den indigo off watter aen dependeert door niemant

1 In 1617 deed Van den Broecke opnieuw een reis naar het westen van Azië. Op dien tocht strandde zijn schip op de kust tusschen Surat en Daman, njn den Grooten Mogols land". Hij richtte daar het „fort ofte barricade ten Broecke" op, hetwelk hij den 21 Aug. 1617 met de zijnen verliet voor Surat, om zijn merkwaardige reis dwars door Dekkan te beginnen. Die tijdelijke versterking lag tusschen Bulsar en Gandivi. Van den Broecke's plan was, het Nederlandsche kantoor te Mazulipatam te bereiken. De weg, door hem gevolgd, is op de tegenwoordige kaarten zeer goed na te gaan. Hij ging dan eerst naar Surat, vandaar naar Gandivi, verder over Patoda, Amrapoer, Haiderabad (Golconda), Ibrahimpatam, Goentoer, naar Mazulipatam, waar hij den 24 December aankwam. Moeilijkheden, van de inlandsche autoriteiten ondervonden, deden hem besluiten, met zijn troep naar Pulikat te gaan, waar hij den 3 Januari 1618 arriveerde. 
meer, 't sij gouverneur off pachter (onder wat praetext tsoude mogen wesen) gemonopoliseert, gepacht, ofte becommert wert ${ }^{1}$, maer in contra dattet de Nederlanders en de Engelsen ${ }^{2}$, mitsgaders alle andere coopluijden sal vrij staen, die van de bouwluijden te coopen ende de bouwluijden aende cooplieden te vercoopen.

Dat sijne $\mathrm{Maj}^{\mathrm{t}}$ niet en begeert ende expres verbiet de residenten off opperhooffden dieder van wegen de Nederlantse ende Engelse Comp ${ }^{3}$ in Suratte resideren, meer uijt Suratte naer Suhalij ${ }^{3}$ naer hun schepen (om daer besoignes aldaer te verrichten) zullen mogen reijzen, maer d'opperhooffden van de schepen in Suratte comen ende aldaer consulteren, wegen tgeene in negotie te verrichten hebben. Wijders dat elk 12 lack ${ }^{4}$ off 1200000 ropias aen coopmanschappen offte contant gestadich tot een onderpant moeten houden, ende voorders dat geen van beijde Comp $\mathrm{p}^{\text {ies }}$ met haere schepen meer voor de revier van Suratte sullen mogen setten om hunne goederen de revier op ende aff te brengen, maer met deselve inde com van Suhalij moeten komen, nochte oock tvaerwater met deese jachten off te fregaten meer te bevaren, etc ${ }^{\mathrm{a}}{ }^{5}$

1 Een der moeilijkheden, waarmede de onzen hadden te strijden.

2 De Nederlandsche opperkoopman Pietersen en de Engelsche president William Metholt werden gezamenlijk door den Gouverneur opontboden, om de fermans te hooren voorlezen.

3 De z. g. „kom van Suhalij", benoorden de monding der Tapti (tegenwoordig Savali), toen de ankerplaats der Nederlanders, Engelschen enz.

4 Lack beteekent honderdduizend en vooral 100.000 ropy's (Hobson-Jobson, p. 381, v.). Een zilver ropy te Surat was in Valentijns tijd 30 stuiver (Batavia, bldz. 359), in 1693 waren zij binnen 's Compagnie's gebied gangbaar voor 28 zware stuivers (Plakaatboek, III, bldz. 345), ongeveer 1640: 24 stuiver (B̈̈jdragen Hist. Gen., III, bladz. 338).

${ }^{5}$ Deze tweede ferman beviel niet aan de onzen en de Engelschen, maar de Gouverneur zei later aan Pietersen, dat deze beperking "niet ons, maar alleen d' Engelsen raeckte, omdat sij met haer cleijne jachten in der Portugijsen plaetsen swurven; hare goederen de rivieren Brootcha ende Cambaija meenden op te voeren, voor de rivier hare goederen losten, ende waer sij conden off mochten, hem sijn incomen ende thollen sochten t'onttrecken." (Dagh-Register 1636, bldz. 113). Wat de Gouverneur aan Metholt zou hebben gezegd? 


\section{BENGA LEN.}

\section{September 1636.}

Niettegenstaande den ferman van 1 Augustus 1635 (hiervóór bldz. 268), bleven de vexaties, waaronder de onzen bij hunnen handel op Bengalen leden, voortduren (Dagh-Register 1636, bldz. 243, 244, 274; vgl. hierna, bldz. 282). Men deed daarom ijverig pogingen, den Grootmogol in ons belang te winnen en onderstaande ferman werd verkregen door den oppercoopman Barent Pietersen te Surat „door behulp van den geweesen Zuratsen gouverneur Mirmosa (zie hiervóór, bldz. 269) ende andere grooten." Den 8 October werd dit stuk van Agra naar de onzen in Hoegli gezonden; het kon dus slechts resultaat hebben later dan net accoordt van 18 September, hierachter volgende (Dagh-Register 1637, bldz. 105).

Translaat vant firman door Zijne $\mathrm{Maj}^{\mathrm{t}}$ den grooten Mogol ofte Coninck Chajean aende Neerlandtsche Comp ${ }^{\text {ie, }}$ om liber en vrij door ende in gans Bengala te mogen negotieeren, houdende op Isalamchan ${ }^{2}$, groot gouverneur in Bengala.

Hooft van alle ervarentheijt onder wiens schaduwe oock alle eerbaerheijt schuijlt, stander van alle landen, aller coninghen hoeckpilaer, bewaerder der coninghen schatten, weerdich om van coninghen bemint te wesen, uijtmuntenste onder alle mijne amarauwen, ${ }^{3}$ aengenaemste van alle mijne raetsheeren, tot wien mijn genegentheijt soodanich niet en can zijn, off zijn merijten zijn noch veel grooter, jae soodanich dat het met de monde niet uijtspreecken can, wien ick oock houde ende aenneeme (omdat ick hem van joncx op gekent hebbe) als mijn bloetmaghe ende wien ick oock in alles raet vrage, zijt ghij, namentlijck Isalamchan; gedenckt dat gij de eere, trespect ende de goede genegentheijt dien ick tot $u$ draghe in goede achtinghe neeme.

Ick doen Ul. condt als dat de Hollanders groote machtige cooplieden zijn ende dat sij groot misnoeghen hebben genomen over dat de Portugeesen in Bengalen veel van hun voleq met vergiff vergeven ende omgebracht hebben, tweleq Ul. wel behoorden te weeten.

1 Overgenomen uit Dagh-Register 163\%, bldz. 105.

2 Islam Khan toch zeker. Een nieuwe bijdrage voor de gegrondheid mijner vraag, of Hunter zich niet vergist heeft in de chronologische opvolging der nababs van Bengalen (Zie hiervóór, bldz. 268, noot 5).

s Vgl. Hobson-Jobson, p. 11 f., sub voce "Ameer"? 
Ende aengesieu dat d'Hollanders in mijne bandaers ende landen comen om vredelijck haere negotie te drijven ende dat zij haer onder mijne schaduwe ofte protecxie begeven ende niets tot malitie ofte prejuditie van mijnen staet practiseeren, maer mijue landen met haere negotie verbeeteren, haer gedienstich ende gewillich tmijnen besten thoonen, ende dat d'ondervindinghe ous heeft geleert, d'gemelte Hollanders een sinceere, fidele ende oprechte natie is, soo beweecht het ons, onse oogen over de selve te slaen, haer in goede achtinghe te houwen ende haer in alles behulpsaem te zijn. Weshalven recommandeeren ick Ul. dat Ul. haer in alles, waerinne zij Ul. noodich hebben, zult behulpsaem wesen ende letten dat haer van de Portugeesen geen overlast geschiet. Godt heeft de Portugeesen eens gestraft, casseertse voort ende doetse aldaer uijt mijn landt gaen ende vertrecken, weert oock datse voortaen niei weder in Bengala comen handelen opdat Ul. vandeselve t'eenigertijt door haer valsche practijcquen niet bedroogen wert. Voorders tot een besluijt gebiede ick Ul., alsdat Ul. dit ons mandaet ofte gebodt naer compt ende in achtinghe neempt, opdat $\mathrm{Ul}$. daerdoor onse gunste (die tot Ul. groot is) noch meer ende meer mocht doen aenwassen ende vermeerderen, etc ${ }^{\mathrm{a}}$.

Actum in Mandou ${ }^{1}$ den 23 dach der maen Serrewaer ${ }^{2}$ int 9 jaer onser regeeringhe ende A Mahomet 1046 den 13 dach der maent Ribbelacher, ${ }^{3}$ sijnde volgens onse recquening den 16 September 1636. ${ }^{4}$

1 Mandu (Mandogarh) in Malwa (22 $21^{\prime}$ N.B., $75^{\circ} 26^{\prime}$ O.L.)? Vgl. Hunter, Gazetteer, VI, bldz. 303.

2 Shariur? Over de tijdrekening onder sjah Jehan zie Cunningham, Indian eras, p. $83 f$; Sewell, Indian Calendar, p. $46 f$.

3 Rabi al-achir.

4 "Uijt den inhout van dit firman blijckt seeckerlijk .... de groote gunste, die den Coninck desen Isalamchan toedraecht, alsoo hem volgens ons gedaen versouck geen wetten begeert voor te schrijven hoe hem met d'onse wegen de tollen ende andere gerechticheden aldaer zal draghen, waeruijt te beduchten is, dit tweede firman alsoo weynich alst eerste (zie hiervóór, bldz. 286) sal werden geacht, ende dat de Compie aldaer nimmermeer den gewensten handel sal optineeren, dat den tijt zal openbaren" (Dagh-Register 163\%, bldz. 106). 


\section{VII. BENGALEN.}

\section{September $1636 .{ }^{1}$}

Ofschoon de handel dan was beproefd in Bengalen, vlotten wilde hij niet tengevolge der tegenwerking van plaatselijke autoriteiten van Hoegli. Ook de Stadhouder, ofschoon den onzen niet onvriendelijk gezind, toonde geen overgroote geneigdheid, aan de O.I.C. "den vrijen handel" toe te staan, te meer daar de handel in Hoegli verpacht was. De Nederlanders hadden inmiddels van den Grootmogol een ferman gekregen (1635, hiervóór $\mathrm{n}^{\circ} \mathrm{CXI}$ ), waarbij de vrije handel in Bengalen hun werd vergund. Ook hierop sloeg hij weinig acht. Toch bleef de Compagnie er een vertegenwoordiger houden, niettegenstaande „de Moorsche groote quellagien" (DaghRegister 1636, bldz. 243, v.; 270, v.; Dagh-Register 1637, bldz. 96-102). In Augustus en September 1636 bereikten deze kwellingen een ongekende hoogte. Toch ontving den 18 October de opperkoopman Jacob Mahuysen of Mahieusen onderstaand geschrift, den 18 September 1636 door den Stadhouder verleend (ook afgedrukt in 't Dagh-Register 163\%, bldz. 99, v.), door middel van groote "vereeringhen" aan verschillende invloedrijke personen.

Accoordt met den nabbab Eslimchan gemaeckt in Decca ${ }^{2}$ den $18^{\text {e }}$ September 1636.

Die van Ouglij sullen weten, dat wij met de Hollanders zijn verdragen ende haer caul verleent; gelijck met haer hebben veraccordeert, zullt gijlieden doen. In dese maniere sijn met haer verdragen, gelijck den Touchedaer ${ }^{3}$ ende Cororij ${ }^{3}$ alles bewust is; ende daer zij $\mathrm{t}$ goedt vinden, moeten de Hollanders hare schepen anckeren, moet maeken haere schepen gaen ende komen ende zijlieden het gecontracteerde aengaende des Conings tol betalen, te weten van een groot schip 3000 , van een middelbaar 2000 ende van een cleijn 1200 ropias ${ }^{4}$.

Als de schepen eenige taffa's offte rariteijten medebrengen, moetent aen den Touchedaer, Cororij offte andere grooten alldaer verthoonen, alleer 't sellve mogen vercoopen ende soo ijets aenstaende is, zall bij de makelaers gewardeert ${ }^{5}$ worden. De Hollanders daerover niet

1 Uit het Contractboek.

2 Dakka, zetel van den Nabob of Stadhouder: aan een der zijtakken der Meghna, den Oostelijken Ganges-mond (Vgl. Hunter, Gazetteer, II, bldz. 4, 11).

3 Blijkbaar persoonsnamen. Cororij was een der "opperste pachters" (DaghRegister 163\%, bldz. 96) en een onzer tegenstanders.

424 stuivers. Zie bewijsplaatsen o. a. bij Hobson-Jobson, p. 586.

${ }^{5}$ Dagh-Register: gemandeert (vermoedelijk onjuist). 
te vreeden zijnde ende magh haer geen force aengedaen worden ende $d^{\text {os }} t$ selve aen andere te vercoopen niet verhinderen.

De Hollanders mogen geen jnlandsche dienaers in dienst nemen, ten ware het den noodt vereijsten, die alsdan moeten mette maendt aennemen ende op haer vertreck afdanckende ${ }^{1}$ betalen sonder deselve te mogen vervoeren.

De zeijlen ende boot moet men haer niet affvergen, nogh de sleutell van haerlieder schepen aff te eijschen.

Jnt opcomen ende vercoopen van haerlieder goederen moet men haer niet lasstigh vallen offte hinderlijck wesen.

Sij mogen geen bossekruijt, sallpeter, slaven offte slavinnen opcoopen nogh min vervoeren.

Als hare schepen ter behoorlijcke plaets geanckert leggen, sullen zij des Cororij's volck daerinne leijden ${ }^{2}$, om haerlieden ['t] mede gebraghte te vertoonen, waervan niets mogen aghter de handt houden offte verswijgen, ende gelijck manier is, haerlieder goederen in presentie der maekelaers verkoopen.

Van haerlieder schepen sullen als boven tholl betalen ${ }^{3}$.

't Gene zij in Ouglij niet ${ }^{4}$ connen vercoopen en comen te vervoeren, daervan sullen als andere cooplieden tholl betalen. De Hollandsche dienaers als bootgesellen ende andere en moet geen overlasst geschieden, nogh men magh haerlieden niet pressen eenigh werck te doen offte verhinderen eenigh goedt van ende aen boordt te brengen.

De Cororij moet haerlieden een lighte woonplaets maeken van stroomatten en bamboesen, voor de coopmanschappen een aerde packhuijs, reegen ende brandtvrij, twelck zij van hem zullen moeten huren ende en mogen geen steenen versoecken.

De Portugeesen, die in Oughlij offte Balij ${ }^{5}$ comen, en moet van de Hollanders geen overlast geschieden.

Als zij het gecontracteerde aengaende de scheepen betaelt hebben ende de mouson gecomen is, moet men haerlieden laten vertrecken ende niet hinderlijck sijn offte ophouden ende soo het gecontracteerde niet meer naer en quamen offte betalende ${ }^{6}$, zullt haerlieden ophouden ende ons alles toeschrijven.

1 Dagh-Register: affdancken ende betaelen.

2 Dagh-Register: seijnden.

3 Deze alinea komt niet in 't Dagh-Register voor.

4 Dit woordje komt niet in het Dagh-Register op deze plaats voor.

5 Vermoedelijk Bali ten noorden van Kalkutta.

6 Dagh-Register: betaelden. 
't Gene met haerlieden gecontracteerdt ende toegeseijt is, moet van Ul. aldaer aghtervolght worden ende jn alles naergecomen, dat Ul. alles moet in goede aghtinghe nemen.

\section{SIAM.}

\section{September 1636. ${ }^{1}$}

Onze eerste aanrakingen met Siam dagteekenen reeds van 1604 , toen de admiraal Wijbrand van Waerwijck, te Patani vertoevende, Cornelis Speex als gezant zond naar den beheerscher van genoemd rijk (De Jonge, Opkomst, III, bldz. 23, 62). Het werd een tusschenstation voor de vaart en handel op Japan (Tiele, Bouwstoffen, I, bldz. III, 62): hertevellen, sapanhout en andere artikelen voor de Japansche markt werden er opgekocht, terwijl de Siamsche rijst een voor de O. I. C. welkom voedingsmiddel werd: in 1625 voorzagen Siam en Japan de onzen in den Archipel geheel van rijst, in 1628 zou Batavia hongersnood hebben geleden zonder den rijstaanvoer uit Siam. Immers Java was bij de gespannen verhoudingen met Mataram in die dagen een onberekenbaar rijst-export-land. De betrekkingen met Siam bleven bestaan; ook toen Coen in 1622 onze factorij daar lichtte, werden handelsbetrekkingen daarmede onderhouden, beleefdheden gewisseld, enz. Siam was gaarne met ons op goeden voet, vooral de onwettige vorst, die tengevolge der gebeurtenissen van 1628 en 1629 op den troon kwam en met omliggende staatjes (o. a. het van Siam min of meer afhankelijk Patani) in strijd geraakte. Maar ongenegen was hij, ons een monopolie te verleenen in sapanhout en hertevellen. In 1633 werd tot directeur van onzen handel in Siam aangesteld Joost Schouten, welke tot 1636 deze waardigheid bekleedde. Hem werd het gevraagde monopolie beloofd, mits de O. I. C. hulp verleende tegen Patani. Schouten was van meening, dat het recht bij Siam was en ried aan, hulp te verleenen, wat in 1634 gebeurde. Hoog stegen de onzen in de gunst des Vorsten, ofschoon onze hulpbetooning bleek te zijn eene "vruchteloose assistentie"; hij verminderde "de ordinary gerechticheyden" tot op de helft ${ }^{2}$. Patani onderwierp zich in 1636 aan de eischen van Siam. Maar ongeveer dezen tijd kwamen de onzen in minder aangename verhoudingen tot Siams beheerscher. Vermoedelijk bevreesd voor het toenemen onzer macht, ontstemd over onze betrekkingen met het hem niet vriendelijk gezinde Kambodja, legde hij aan de onzen allerlei belemmeringen in den weg, "soeckt onse aldaer voor deesen gegaudeerde vrijicheijt ende lieberen handel te bepalen, ende ons nae sijn pypen te doen dansen." In 1635 bereikte de vijandige stemming een gevaarlijke hoogte en het leven van onze vertegenwoordigers in Siam was ternauwernood zeker. In September 1636 deed de Koning den koopman Jeremias

1 Overgenomen uit Dagh-Register 163\%, bldz. 139.

" De desbetreffende "ordonnantie in de behoorlijke forme" (Bouwstoffen, II bldz. 264) is afgedrukt in het Tïdschrift Ind. T., L. en Vk., XII, bladz. 440. Ik vind niet noodig, haar hier op te nemen. 
van Vliet, die aan Schouten was opgevolgd, „d'onderstaende acte passeeren ende onderteeckenen" (Vgl. Bouwstoffen, II, passim; Dagh-Register 1624-1637, passim; Tïdschrift Ind. T., L. en Vk., XII, bldz. 410, v.v.).

Copie vande acte door den Siamschen coninck den coopman Joannes ${ }^{1}$ van Vliet afgedrongen te passeeren ende nae te coomen.

Op den $5^{\text {en }}$ dach der wassende maene, genoemt dungij int ratten jaer, heeft Oija Berckelangh ${ }^{2}$, door den Sabander Olangh Tsuijt Raijmontrij dit geschrifte van mij, Jeremias van Vliet (opperhooft over 't Siams Compa comptoijr ende ommeslach in Siam) gevordert, bij 't welcke beloove, dat alle 't gunt van nu voortaen uijt den naem van gemelten berckelangh aen mij ofte de Neederlanders die in Siam resideeren, door den sabander ofte tolck zijn belast offte gerecommandeert wort, voor sooveel in ons vermoogen is conforme de wetten en de costuijmen deses rijckx gehoorsaemlijck sal naegecomen worden, ende dat ick (als 't hooft sijnde) voor de contraventeurs sal moeten caveeren, waeronder mijn persoon verbinde.

In Judia ${ }^{3}$ op 't comptoijr Siam, adij ultimo September $A^{0} 1636{ }^{4}$.

\section{Bengalen.}

\section{0ctober-November 1636. 5}

Ten gevolge der gebeurtenissen van Augustus en September (zie hiervóór, bldz. 282) besloot Mahuysen „opt aenschrijven" van Carel Reniers, toen gouverneur der Kust van Kormandel, waaronder de Nederlandsche

1 Schrijffout voor: Jeremias.

2 De Phra-Khlang: tusschenpersoon tusschen Vorst en vreemdelingen, vooral met het oog op den handel, waarvan hij het hoofd was (Hobson-Jobson, p. 551; Kronïk Historisch Genootschap, IX, 1853, bldz. 298; vgl. Tïdschrift Ind. T., L. en Vk., XII, bldz. 391).

3 Ajoethja, toen Siams hoofdstad, aan de Menam.

${ }^{4}$ "Hier en booven heeft dese cooninck noch belast, dat alle vaertuijgen van de aencoomende scheepen int opvaeren vande revier aen Bancock sullen aenleggen, ende aldaer des coninckx officieren aendienen van waer dat coomen, en soo langhe vertoeven tot dat den berckelangh daer van is verwitticht, die sulckx den cooninck sal cont [doen] ende alsdan een trae offte pascedel derwaerts senden moogen, dat voorwaer onverdraechelijek is ende int spoedigh versenden van Compie scheepen van Taijouwan ende Japan impediment geven sal ...." (Dagh-Register 1637, bldz. 139, v.).

5 Overgenomen uit Dagh-Register 163\%, bldz. 244. 
aangelegenheden in Bengalen ressorteerden, "met de minste commotie met alle de Comps effecten van Oeglij naar Pipelij ${ }^{1}$ te vertrecken ende den handel aldaer te doen vervolgen." Toen nu bleek, dat „in Oeglij voor de Comp ${ }^{\circ}$ geen segure noch vaste negotie, ongeacht het tweede door Sr Barent Pietersen overgezonden firman (zie hiervóór, bldz. 280) te erlangen zij, noch te verwachten hebben", werd dit besluit ten uitvoer gelegd. Den 29 December "van Oeglij de Ganges affgedreeven zijnde”, kwamen de Nederlanders den 13 Januari 1637 vóór Pippli ten anker. De gouverneur van die stad toonde „hem over haere compste seer vergenoecht” en stond toe "den vrijen lieberen handel met een manier van verleent caul". 2

Inmiddels had Barend Pietersen van Surat ferman van sjah Jehan weten te verkrijgen nopens den handel in Bengalen, waarvan hij bij schrijven van 13 Januari 1637 een afschrift zond aan Reniers, terwijl het origineel „over Agra" aan Mahuysen was gezonden (Vgl. Dagh-Register 1637, bldz. 112, 238, v.v.).

Translaet uijtt d'copia vant derde firman 't welck zijne Maijs $^{t}$ den grooten mogol ofte den coninck Chajean aende Neederlantsche Comp ${ }^{\text {ie }}$ om lieber ende vrij in ende door gants Bengale te mogen negotieeren, mitsgaders hoeveel d'gemelte $\mathrm{Comp}^{\text {ie }}$ aldaer voor tol van incomende ende uijtgaende goederen betaelen zullen, in Sijandijgotij ${ }^{3}$ int leeger in November +1636 heeft [verleent], welckers inhoudt ende lectura luijdt als volcht.

Alle gouverneurs, overste gebieders, stadthouders ende bevelhebbers in Bengalen, sij condt hoe de Hollanders (d'welcke machtige coopluijden zijn) aen mijn een firman hebben versocht om alderwegen in Bengala, soo in Ouglij als andere plaetsen met haer scheepen te moogen comen handelen ende voorders haeren handel met hun coopmanschappen lantwaert inne te mogen drijven, soo ist, alsoo wij bericht zijn dat ouse landen in Bengala door de handelinge van dese natie seer sullen verrijckt ende ons incomen vermeerdert werden ende oock dat onse vasaelen aldaer door dittos handelinge seer veele zullen proffijteeren, dat ick aen alle mijne gouverneurs, overste gebieders, steedhouders ende bevelhebhers in Bengala beveelen, dat sij gemelte Hollanders 'tsij in wat stadt, poorte ofte

1 Pippli aan de Subarnarekha ten Z.W. der Hoegli, in het Bengaalsche district Balasor. De plaats schijnt thans te zijn verdwenen (Hunter, Gazetteer, VII, p. 373. Vgl. Valentijns kaart van Bengalen in V, 1).

2 Niet meer aanwezig.

3 Ligging mij onbekend.

4 Over deze dateering zie aan het slot. 
zeehaevenen daer sij soude mogen comen, over all den vrijen ende lieberen handel toestaen ende haer over all niet alleenelijck wel tracteeren maer oock haer in haere negotie naer haer uijtterste vermogen adjudeeren ende weeren sullen, dat hun van niet eenighe overlast ofte empedimenten in haere negotie nochte aen haere persoonen geschiet. Invoegen tracteert haer soodanich in alles dat sij daer uijtt contentement ende geen missnoegen en scheppen, opdat sij dies te beeter in haere negotie mogen gehandhaeft werden; als om voorders voor te comen dat hun niemandt eenighe onlusten aendoen, soo willen ende begeeren wij, dat onse gouverneurs ende opperste gebieders in Bengala selffs in persoon haer negotie sullen hanthaeven, item dat se oock haere zaecken die zij te verrichten bebben selffs sullen verhandelen ende niet dat men d'Hollanders aen haere dienaers ofte minder bevelhebbers om dittos soecken te verhandelen, sullen renvoijeeren, op [dat] dittos niet door d'nonchelance onser gouverneurs oft de begeerlijckheijt haerders dienaers in 't een off 't ander vercordt werden. Soo UE. haer dan in alles wel tracteert, ende haer in haere negotie adjudeert, salt niet mancqueeren off de gemelte Hollanders sullen daer over een goet genoegen scheppen, ende onse landen meer ende meer van tijt tot tijt met haere negotie verbeeteren.

Belangende hoedanich UE. met haer over thollen der incomende ende uijttgaende goederen handelen sult, 't selve hebben achter op dit firman geschreven; wij gebieden 't geene wij hier booven ende achterop 't firman geschreven hebben, met dittos, sonder aff ofte toedoen, soodanich handelen sult. ${ }^{1}$ D'gerechticheeden die aldaer voor desen genooten zijn, houden wij bij desen voor geanuleert ende van geender waerden, maer Ul. sal op den vertooch van dit ons firman vande gemelte Hollanders den tol in soodaniger manieren voorderen als zij die in Zuratte betaelen ende soo als ons de selve den gouverneur Mirmosa ${ }^{2}$ mitsgaders onsen cannagon ${ }^{3}$ ofte maeckelaer vande alphandigo * in Suratta van alle Hollanders, Engelsche, Portugeesen,

${ }^{1}$ "Nota ondert firman heeft Affselchan, des coninckx cancelier, met zijn eigen handt geschreven ( $t$ welck niet veel goets is) alsdat de Bengaelse gouverneurs d' bovenstaende tollen jegens die in Bengala genomen werden confronteeren ende dat sij voorderen zullen welcke den coninck de meeste proffijten geven (Dagh-Register 163\%, bldz. 246).

? Zie hiervóór, bldz. 269, 280.

3 Vgl. Hobson-Jobson, p. 121, 772, sub voce "Canongo".

4 "Tolhuijs off alphandigo" (Dagh-Register 1641, bldz. 190). 
Mallebaeren, Armeniers ende andere coopluijden in reeckeningh gebracht heeft, te weeten ${ }^{1}$ :

- Van gemundt ofte ongemundt goudt ofte silver, tsij voor uijtt gaen ofte incomen 2 per cento; van alderhanden mantimentos voor uijttgaen $2 \frac{1}{2}$, voor incomen $3 \frac{3}{4}$ per cento; van indigs bijana ${ }^{2}$ voor uijttgaen ende incomen 4 mamoedij ${ }^{3}$ per pack van 4 man ${ }^{4}$; van indigo chirchees ${ }^{2}$ voor uijttgaen ende incomen 3 mamoedij per pack; van nagelen, nooten, folije, vermelioen, quicksilver, solpher, loodt, tin, cooper, lijnwaet, $\mathbb{\Xi}^{\mathrm{a}}$, wat goederen 't soude mogen wesen, voor incomen als uijttvoeren $2 \frac{1}{2}$ per cento.

Voor oliphanten, paerden, cameelen, esels, bocken ende schapen uijttevoeren $2 \frac{1}{2}$ per cento; voor provisie tot de voijage als plunderagie ${ }^{5}$ tot des volcx lijffs cleedinge, daerinne sal men discretelijck handelen, 't sij dat men wat neempt off niet.

Van soudt in ende uijttvoeren $4 \mathrm{p}^{\mathrm{r}}$ cento.

Voor slaeven uijtt ofte invoeren, alst Mooren zijn 12 ende Abessies ${ }^{6}$ ofte andere 7 percento; boven dese tolle ofte gerechticheeden sullense noch aende maeckelaer ofte canagon vande alphandigo van alle incomende ende uijttgaende goederen voor maeckelaerdige betalen een per cento ende aenden siapper om de goederen te siappen ${ }^{7} 4$ tacco ofte 8 peysen ${ }^{8}$ per cento; omde volgende goederen uijtt landt met carren ofte anders in de stadt te brengen, off uijtt de stadt landwaerts inne te voeren, daar voor sullen zij voorde gerechticheijt vande poorte betaelen 't volgende:

Van nagel en folije, nooten, campher, quicksilver, benjawijn ${ }^{9}$, cooper, solpher, indigo, mirhe, catho ofte cattie ${ }^{10}$ : van ider man 4 tacca ofte 8 peijs.

${ }^{1}$ Ik neem deze lijst hier op, omdat zij ons een kijkje geeft in de handelsbeweging in het rijk van den Grootmogol in die dagen.

${ }^{2}$ Vgl. Valentijn, IV, 2 (Suratte), bldz. 146. Een plaatsje Biana (waarop wij handel dreven, vgl. Kronijk Historisch Genootschap, IX, 1853, bldz. 312) ligt in Bhartpoer (Rajpoetana) op cirea $27^{\circ}$ N.B. en $77^{\circ}$ O.L. ten Z.W. van Agra.

${ }^{3}$ Perzische munt, welke in Valentijn's tijd in Surat $13 \frac{1}{3}$ stuiver deed (Valentijn, IV, 1, Batavia, bldz. 359).

${ }^{4} \mathrm{De}$ man varieerde in Valentijn's tijd (V, 1, Choromandel, bldz. 179; Batavia, bldz. 361) van 63 tot 71 pond naar gelang der koopwaren. Vgl. ook Hobson-Jobson, p. 431 en vooral hierachter no CXXVIII.

${ }^{5}$ Kleeding, enz. van het scheepsvolk, plunje.

${ }^{6}$ Abessyniërs?

7 Zegelen, merken, stempelen.

8 Valentijn, Batavia, bldz. 359: " 1 Ropia doet ook 30, en klimt wel tot 34 Peyzen...." Vgl. ook Hobson-Jobson, p. 533, sub voce "Pice”; Bïdragen Hist. Gen., III, bldz. 338.

9 Benzoë.

10 Vgl. Hobson-Jobson, p. 133, sub voce "Catechu". 
Van loodt, wacx, salpheeter, peeper, lack, ruijnas ${ }^{1}$, hoonich, conservo ${ }^{2}$ ofte confituren twee tecca ofte 4 peijs per man.

Van medicinale drogien ${ }^{3}$, areecq ${ }^{4}$, cocus, drooge ende natte dadels, hinge ${ }^{5}$, safferaen, comijn, amandelen, hennip, zeep $\frac{1}{2}$ tecca ofte een peijs per man.

Van buffelsleer $\frac{5}{8}$, ossen $d^{\circ} \frac{1}{4}$ peijs van ider stuck, ende van schaepen leer 2 per corgie $^{6}$, voor houdt werck ende bamboesen $\frac{2}{5}$ peijs per car.

Soo wanneer d'Hollanders met haer scheepen in Bengala comen, sullense gehouden sijn, dat sij met geen geweer, 't sij met roers, piecken, houwers off anders als alleenelijck met een mes vermogen aen landt te comen, oock dat sij [met] geen meer volcx als met 20 off 30 persoonen teffens aen landt zullen comen ende dat als die te scheep gaen wederom ander in haer plaetsen comen mogen, $\&^{\mathrm{a}}$.

Acto anno Mahummet 1046 , den $23^{\text {en }}$ dach der maent Sumadel Auwel ${ }^{7}$, ende onser regieringe 't negenste jaer, den $4^{\text {en }}$ dach der maent $\mathrm{Aba}{ }^{8}$.

\section{KUST VAN KOROMANDEL.}

\section{November 1636. 9}

De gouverneur van Mazulipatam trachtte ons ook in Petapoeli 10 moeilijkheden in den weg te leggen hetwelk tot bloedstorten aanleiding gaf. Opnieuw werden pogingen bij het Hof aangewend, om óók hier tot rustiger verhoudingen te komen, welke werden bekroond met den onder-

1 ?

2 Port.: conserva $=$ gelei, enz.

3 Drogerijen.

4 Areka, betelnoot, pinang, sirih.

5 Hingoe, asa foetida (Vgl. Hobson-Jobson, p. 318; Valentijn, Suratte, bldz. 146).

6 Een twintigtal (Vgl. Hobson-Jobson, p. 197).

7 Djoemada 'l-awwal 1046 loopt van 1 October tot 30 October 1636. De dateering in den aanhef: "November" is dus onjuist of wijst op de maand, waarin het stuk in het bezit van Pietersen is gekomen.

8 Abân (Sewell, Hindu Calendar, p. 47)?

9 Uit het Contractboek.

10 Blijkbaar had hij toen ook hier het heft in handen (Dagh-Register 1636, bldz. 264; vgl. echter hiervóór, bldz. 242). Misschien was Petapoeli een ondergouvernementschap van Mazulipatam. De gouverneur, van wien hier sprake is, was niet meer dezelfde als die in 1630 was aangesteld geworden (Vgl. hiervóór, bldz. 235).

7• Volgr. III. 
staanden ferman (Zie Dagh-Register 1636, bldz. 264 v. v., 283; 1637, bldz. 91 , v., waar het stuk ook is afgedrukt).

Ferman van den $\mathrm{k}^{\mathrm{k}}$ van Golcondia aen d'onse verleent.

Boven stondt des Konings naem met zijn eijgen handt geschreven: Sulltan Abdula Godophia.

Ick coninck in gelijckenisse bij de opgaende zonne, die den gansschen aerdtbodem verlightet, naest Godt de grootste deser werelldt. ${ }^{1}$

Onder mijn lieffelicke schaduwe hebt ghijlieden veell jaeren geschuijlt ende segge, dat ich Ul. meeninge een corten tijt geleden uijt Ul. schrijvens hebbe verstaan. Den Gouvern ${ }^{\mathrm{r}}{ }^{2}$ heefft Ul. ende Ul. volck voor mij met veell actie grootelijex beschulldight ${ }^{3}$, dat Ul. eenige gewellden hem soudt hebben gedaen ende nieuwe cosstuijmen soekt in te voeren; dogh vertrouwen ende beellden ons in, sulcx soodanigh niet te sijn. Hierop hebbe mijn gouverneur gemandeert, dat zall traghten met Ul. in alle vrundschap ende redelijckh ${ }^{t}$ om te gaen. Ick hebbe hem ook voorgehouden, off hij Ul. eenigh gellt affgedrongen hadde, waerop hij geandtwoordt heefft, soo Ul. sulx voor den Sarsamel + ende Sabandar conde betuijgen, hij. Ul. wederom restitueeren soude, 't welck hem oock belast hadde. Mede dat sall letten, Ul. niet alleen van hem maer ook van eenige ${ }^{5}$ andere overlast geschiedt. Ul. offte Ul. volck moeten ook niet buijten de redelijck ${ }^{t}$ gaen offte eenige nieuwe cosstuijmen jnvoeren. Het contract tusschen Ul. ende mij gemaeckt, geliefft op zijn behoorlijcke tijt te betalen ende dan mooght met gerusth ${ }^{t}$ Ul. negotie drijven. Indien Ul. hier op eenigh gewelldt van ijmandt, wiet ook soude mogen wesen, geschiedt, doet mij sulx weten: 't selve mij ter kennisse komende, zall ze doen straffen ter excempell van andere. Ul. zijt mijn volck; drijfft $U$ negotie gerustelijck; mooght op dit mijn woordt vertrouwen. Dit is mijn firman, 't welck alle gouvern ${ }^{\text {rs }}$ ende andere prijvate persoonen moeten gehoorsamen.

Gegeven den $29^{\mathrm{e}}$ der maendt $\mathrm{s}$ Jamadissanij offte naer onse reckeninge den $27^{\circ} 9^{\text {ber }} A^{0} 1636 .{ }^{6}$

${ }^{1}$ Het Dagh-Register heeft hier nog: „Aenden Cap ${ }^{t}$ der Hollanders in Masilipatnam sijnde, machtich ende als een tijger ter zee, hooft over de zijne, geve dit mijn firman."

2 Van Mazulipatam.

s Vgl. Dagh-Register 1637, bldz. 91.

4 Dagh-Register: "Sarsanet".

5 Dagh-Register: geenighe.

${ }^{6}$ De $27^{\text {sto }}$ November 1636 valt op den $29^{\text {sten }}$ Djoemada 'l-achir. 


\section{DJAMBI.}

\section{December 1636. 1}

$\mathrm{Na}$ het verdrag met Djambi van 25 October 1621 (zie hiervóór, bldz. 174) bleven de handelsbetrekkingen - peper was hier in de eerste plaats gezocht - voortduren, met afwisselend resultaat en onder afwisselende gezindheid ten opzichte van elkander. Een rustpunt op den weg was onderstaande overeenkomst (vgl. Tiele-Heeres, Bouwstoffen, II, bldz. XXIV, v.v., LXXIV, v.; Dagh-Register, 1624-1637, passim; Mac Leod, O. I. C. op Sumatra in Indische Gids, 1903, bldz. 1254, v.v., 1913, v.v.), opgemaakt in den vorm van "vraghen ende voorstellingen" van de zijde van Djambi en antwoorden daarop van den kant van den koopman Lukas de Vogel, die toen in Djambi onze aangelegenheden behartigde.

Onder dit recht zal staen pangoran Ava ${ }^{2}$ ende het opperhooft der Hollanders in Jambij.

De Nederlanders versoecken dat pangoran Ava ${ }^{2}$ hare voor dese toegestane vrijheden niet vermindert.

$$
1 .
$$

Eerstelijck begeert den Coninck, dat het vaertuijch van Jambij op wat plaets het oock soude mogen handelen niet aengehaelt zal worden ende bij aldien d'Hollanders eenich vaertuijch aenslaen, begeert den coninck tweevoudich sal gerestitueert worden.

Eerstelijck: gelijck voor desen gebruijckelijck is geweest, de plaetse te noemen derwaerts de vaertuijgen sullen vertrecken, alsoo can hierin sonder spesiaale ordre vanden Ed. $\mathrm{H}^{\mathrm{r}}$ Gouverneur Generael niet antwoorden. ${ }^{3}$

2 .

Daer en boven soo eenich handelvaertuijch ofte in ofte uijt Jambij gaet, soot selve vande Hollanders wort aengetast, begeert den coninck,

1 Overgenomen uit Dagh-Register 163\%, bldz. 49, v.v.

2 Moet zijn „pangoran Aria", die in 1636 de regeering over Djambi had aanvaard, na reeds geruimen tijd de feitelijke leiding van het bestuur in handen te hebben gehad (Zie Bouwstoffen, II, bIdz. LXXIV, v.).

3 In deze en de volgende vragen van den Pangeran en het antwoord daarop van onzen vertegenwoordiger ligt een der twistpunten tusschen de O.I.C. en Djambi opgesloten. Reeds sedert eenige jaren hielden wij de jonken van Patani, Siam, enz., die peper gingen laden in Djambi voor andere plaatsen dan Batavia, aan; wij lichten de peper er uit en betaalden die tegen marktprijs (Bouwstoffen, II, bldz. XXVII, noot 1), terwijl andere moedwilligheden niet uitbleven (Vgl. ook het contract met Palembang van 21 Juni 1641). 
dat alle haer goederen haer weder vergoet zullen worden, van Ajer Itam $^{1}$ aff, tot Poulo Bavalla ${ }^{2}$ ende Gualla Tomqual. ${ }^{3}$

Het tweede zullen wij den Coninck bij provisie toestaen; ondertusschen verwachten naerder ordre vande $\mathrm{E}$. heer gouverneur generaal.

3.

Wijders begeert den coninck, dat de scheepen buijten voor Quale Injoor ${ }^{4}$ sullen anckeren ende soose binnen comen, sullense voor de revier Sungeij Assam 's ten ancker comen ende soowel int uijtgaen als incomen sullen door Quala Injoor passeeren.

Doch cunnen niet verwilligen in eenich nieuw ancker plaets, dewijl dit mede een nieuwe vont is, maer moet sijn hoocheijt tselve als mede alle andere nieuwe invoeringhe bij den Ed. Heer gouverneur-generaal versoucken.

4.

Voorders begeert den pangoran, als men den peeper sal wegen, dat deselve met des conincx daetsje ${ }^{6}$ sal gewooghen worden, gelijck oock alle andere coopluijden sullen doen.

Aengaende den daetsjen wij vertrouwen dat den pangoran gerechticheijt in sijn lant sal hanthaven ende geen cleender noch grooter daetche sal in voeren als voor desen gebruijckt is geweest ende de practijcque der Chijneesen int veranderen van de daetsche sal weghneemen, twelck ons sonderlingh aengenaem zal zijn.

ว.

Boven desen begeert den coninck, soo de Hollanders voor de stadt met scharp schieten, ${ }^{7}$ justitie over de selve te doen naer de costuijme van Jambij.

1 Op de Kaart Midden-Sumatra der nieuwe uitgave van Stemfoort en Ten Siethoff's atlas treft men een Ajar Itam Laoet en een Ajer Itam Dalam aan ten Zuiden der Batang Hari.

2 Vermoedelijk poeloe Berhala.

s Zeker de Koewala (monding) der Tongkal-rivier. Deze aanwijzingen geven dus aan de grenzen, ook nog ongeveer de tegenwoordige, van Djambi.

4 De koewala der Soengei Nioer, de Westelijke monding der Batang Hari.

${ }^{5}$ Een der zijtakken van de Nioer.

6 Gewicht: datjin.

7 Een niet geheel ongewone baldadigheid der Nederlanders van die dagen. 
Soo ijmant een groff canon affschiet voor de stadt met scherp geladen, voorwaer zulcx is onbehoorlijck ende tegen recht van vruntschap: deselve sal gemulcteert worden naer rechte van Neerlandt.

6.

Voorders ijmant quetsende begeert dat nae grootheyt der quetsure stervende ${ }^{1}$, dat die geene die geschooten sal hebben door den pangoran gejustitieert sal worden datter de doot naer volcht, ende soo ijmant sal vechten met de Jambijneesen, sal mede nae de Jambijnese rechte geoordeelt worden; van gelijcken soo ijmant van de Jambijneesen sal vechten met de Hollanders, sal mede naar de Jambijneese rechten gestraft worden.

Ende soo ijmant met een coegel ofte andersints in eenich gevecht gedoot worden, versouckt, [dat] sijne hoocheijt indesen onsen oude vrijheijt niet vermindert, maer dat de Jambijneesen na de rechten van Jambij ende onse Nederlanders naar onse Neerlantse rechten moghen geoordeelt worden, gelijck het recht van ambassaetschap ende bontgenootschap is vereijschende.

7.

Mede begeert den coninck, soo ijmandt van de Hollanders sich vermenght met Jambijse vrouwen, dat deselve met soodaenighe recht sal gestraft worden als in Jambij gebruijckelijck is.

Van gelijcken soo sich ijemant vande Nederlanders met een Jambijsche vrouwe vermenght, dat de vrouwe naer de Jambijsche rechten ende de mans na de Nederlantsche rechten sal gestraft worden, uijt cracht vant evengenoemde recht van ambassaetschapp ${ }^{2}$.

8.

Noch begeert den coninck, soo eenich Chijneesch schuldich is aende Nederlantsche Comp ${ }^{\text {ie }}$ ende deselve daerover gebonden ofte in de boijen geslooten wordt, schoon off de Chijnees reden geeft, soo d'Hollanders tselve den coninck niet te kennen gegeven, over de Nederlanders soodanich recht doen als in Jambij sal ganghbaer sijn.

Dit achtste artijckel alsmede de twee voorgaende strijden directelijck

${ }_{1}$ De zin is hier niet geheel duidelijk.

2 Het vraagstuk der exterritorialiteitsrechten was ten opzichte van Djambi reeds sedert eenige jaren een netelige quaestie geweest (Vgl. Bouwstoffen, II, bldz. XXXI, v.; onuitgegeven missive van D. Tresel te Djambi aan GG. Specx, 10 Jan. 1631; J. Oosterwïjck aan Specx, 20 Oct. 1631; Specx aan Oosterwïck, 6 Nov. 1631. 
tegen het oude contract $^{1}$ ende tegen de vrijheeden ons voor desen vergunt; soo wordt mede den beloofden eijscher van d'E. Heer Gouverneur Generael al te spits afgeslaghen ${ }^{2}$, oversulcx cunnen hierinne niet consenteeren, maer verwachten dat sijne hoocheijt hierin sich beter sal beraden, ende dat geen verminderaer maer een vermeerder zal zijn vande immuniteijten ende previlegien d'onse bij sijne hoocheijt voorouders uijt sonderlinghe liefden toegestaen ${ }^{3}$.

\section{KUST VAN MALABAaR.}

\section{Maart 1637, 4}

Den 26 Augustus 1636 werd uit Batavia een vloot van 10 schepen onder bevel van den commandeur Jacob Coper gezonden „naer de custe van Indiën, Goa, Suratte ende Persia", o.a. "om de bharra ${ }^{5}$ van Goa te besluijten, d'aencomende secoursen uijt Portugael t'intercipieeren, de vertreckende craken, \&a binnen te houden, ende den vijandt tsij bij slachleveringh ofte andersints allen mogelijoken aff breuck te doen." Men is midden in den strijd tegen Portugal in het Oosten: een strijd, aangebonden door Portugal, dat de kroon-éénheid met Spanje als motief voor een vijandelijk optreden tegen de koene en gevreesde Nederlandsche handelaren in Indië, opstandelingen toch tegen het Spaansche regiment in Europa, gretig gebruikte; een strijd, door de Nederlanders gaarne aanvaard en sedert het optreden der O. I. C. van 1602 door hen met steeds meer succes en hoe langer hoe systematischer gevoerd, hoe krachtiger het lichaam der Edele Maatschappij zich voelde. Ambon en

1 Dit contract is mij niet bekend.

2 Is mij niet duidelijk.

${ }^{3}$ "Op voor verhaelde antwoorde als de gedaene clachten ende eenige dreijgementen, hadden den coninck eijntelijck toe gestaen dat onze scheepen tot voor Sangrij (Soengei?) Assem ende niet verder mochten opcoomen, zijnde omtrent een musquetsschoot van onze logie, om, soo hij voorgaft, van d'ongelucken, die doort canonschieten in de stadt mochten ontstaen, bevrijt te wesen, daerbij versouckende dat de Voghel aende $\mathrm{Ed} . \mathrm{H}^{\mathrm{r}}$ Generael bij sijne missieve geliefde over te draghen, onse scheepen in toecomende voor Quala Injoor mochten anckeren om daer mede te beter voor de Portugeesen bevrijt te sijn, welcke plaetse d' onse opt begeeren des conincx hadden doen diepen ende deselve met $1 \frac{1}{2}$ vadem water ende bequamer als Quala Sadou (Koewala Sadoe) om de scheepen daerdeur in zee te brenghen bevonden, waerop gemelte Voghel onse ordre is inwachtende. Hiermede bleven alle voirdere questien soot scheen voor die tijt geassopieert..." (Dagh-Register 1637 , bldz. 51, v.).

- Overgenomen uit Dagh-Register 163\%, bldz. 252.

${ }^{5}$ Baar, Portug. barra, toegang tot een haven, zandbank of klippenrij vóór een haven. 
de Molukken gingen voor Portugal verloren (vgl. hiervóór, bldz. 31, v.v., $50)$; in verschillende streken werd het, door aan Nederlanders verleende privileges of ten gevolge van door Nederlanders verworven monopoliecontracten, uit de commercie gesloten; elders toonden zich de onzen geduchte mededingers. In deze jaren hadden de Lusitanen nog slechts, wat betreft den Archipel, staatkundige macht in den Zuidoosthoek (op de Solor- en Timorgroep). Het sterk strategisch en commerciëel centrum voor Oost-Azië, Malaka, was nog in hun bezit gebleven, maar werd steeds meer bedreigd door de Nederlanders. En zelfs bestookten deze hen in dat gedeelte van Azië, waar hun kracht vooral zat, waar o. a de hoofdplaats, Goa, was gevestigd van hun Oostersch rijk: aan de Westkust van Vóór-Indië. De expeditie van 26 Augustus 1636 o. a. toont het.

Met deze vloot ging o. a. naar het Westen van Azië: „Jan van Twisch ${ }^{1}$ als fiscaal over de vloote, ende oock om voor Goa gebruijekt te werden (indien de gelegentheijt sulex toelaet) als ambassadeur aenden coninck van Visiapour, welcken (toen) een vijandt der Portugijsen sijnde gaerne geanimeert saghen, om Goa te lande aentetasten" (Dagh-Register 1636, bldz. 203 v.v.).

De ,coninck van Visiapour".... In het laatste deel der $15^{\text {de }}$ eeuw als feitelijk onafhankelijk rijk gesticht, had het, onder Mohammedaañsche heerschers staande, rijk Bijapoer of Vijayapur zich steeds uitgebreid. Met de hoofdstad van denzelfden naam als centrum (in het presidentschap Bombay, op $16^{\circ} 49^{\prime} 45^{\prime \prime}$ N. B. en $75^{\circ} 46^{\prime} 5^{\prime \prime}$ O. L.) strekte het zich uit in het begin der $16^{\text {de }}$ eeuw óók langs een deel der Westkust van Vóór-Indië: Goa b.v. was een zijner havens, en de Portugeezen hebben deze stad en omgeving in 1510 op Bijapoer veroverd. Overigens wisten de beheerschers van dit rijk over 't algemeen hun macht in de zestiende eeuw uit te breiden en er waren tijden, dat zij als de machtigste der Mohammedaansche vorsten van Dekkan werden beschouwd. Sultan Ali Adil Sjah vereenigde de Mohammedaansche vorsten van Golkonda, Admednagar en Bidar tot een verbond tegen het Hindoe-rijk Vijayanagar, dat dan ook door hen bij den slag van Talikot in 1565 (vgl. hiervóór, bldz. 46, 55, 83) zoo goed als vernietigd werd: slechts een overblijfsel van de vroegere macht bleef. Oók Bijapoer profiteerde en won in macht en aanzien, vooral onder Ibrahim Adil Sjah (1579-1626). Inmiddels was het rijk der Grootmogols opgekomen; Akbar de Groote had in 1556 den troon er van beklommen (vgl. hiervóór, bldz. 276) en gedurende zijne regeering (1556-1605) was hij in Dekkan doorgedrongen. Toch gelukte het hem niet, zijn gezag tot Bijapoer uit te strekken; eerst sjah Jehan wist, na vruchtelooze pogingen eerst, Ahmednagar volledig te onderwerpen en Bijapoer en Golkonda tot betaling van schatting te dwingen. Dit vond plaats in 1636, dus juist in de dagen, waarvan hier sprake is, toen Mohammed Adil op den troon van Bijapoer zat (1626-1656). Bijapoer strekte zich toen in het Noorden uit aan de kust tot onmiddelijk bezuiden Bombay $^{2}$, in het Zuiden tot bezuiden Goa, maar die kustlijn was niet

1 Beter: Johan van Twist, een zeer bekende figuur uit onze koloniale geschiedenis van die tijden, welke b. v. is geweest de eerste Nederlandsche gouverneur van het in 1641 veroverde Malaka.

${ }^{2}$ Dabhol o. a. behoorde tot zijn gebied. 
geheel aan den vorst van Bijapoer onderworpen, o. a. omdat de Portugeezen Goa en omgeving in bezit hadden. Niettegenstaande het opdringen der Grootmogols breidde Bijapoer zich binnenwaarts in Oostelijke en Zuid-oostelijke richting nog steeds uit (Vgl. Hunter, Gazetteer, I, p. 85; II, p. $116 \mathrm{ff}$; III, p. 387 ; IV, p. $336 \mathrm{ff}, 349 \mathrm{f}$; Gribble, Deccan, passim en de kaarten ${ }^{1}$; Dagh-Register 1636, bldz. 114, 250, 273; 1637, bldz. 106.

De aandacht der O.I. C. was reeds spoedig op het rijk van Bijapoer gevestigd en vooral op "vermaerde coopstadt Daboul" (De Jonge, Opkomst, III, bldz. 149, v.) en reeds geruimen tijd vóór de zending van Van Twist in 1636 was men met die stad in aanraking gekomen. De betrekkingen waren niet steeds van vriendelijken aard. Zoo werd ongeveer 1623 met Dabhol vrede gesloten, omdat de kooplieden van Surat hinder ondervonden van den oorlogstoestand met het oog op den Arabischen handel, waarvoor Dabhol een punt van uitgang was, en omdat men den Grootmogol te vriend moest houden, die toen met Bijapoer een verdrag had gesloten. waarbij genoemd rijk hem schatting beloofde (Onuitgegeven missive G. G.\& R. 18 Januari 1624; vgl. DaghRegister 1637, bldz. 260). Ook bij de zending van Van Twist stond de handel met Dhabol op het program. Ook Vengurla, dat tot Bijapoer behoorende, begint meer de aandacht der onzen te trekken. De ontvangst van "den gouverneur van Dabul" was uitstekend en Van Twist vertrok naar de hoofdstad van het rijk, waar hij 13 Febr. 1637 aankomt, onderstaanden ferman verkrijgt en ook overigens uitnemend wordt ontvangen (Dagh-Register 163\%, bldz. 75, 77, 249 v.v.; onuitgegeven "relaes" van Van Twist's legatie 1 Jan.-31 Maart 1637).

Translaet van een firman in maniere van verseeckeringhe, die den coninck sultan Mameth Idabra ${ }^{2}$ heeft doen verleeuen aen den heer Anthonio van Diemen, viceroij vande Hollanders, ten versoecke van zijn ambassadeur Joan van Twist.

Aenden zeer geachten ende hoochgepresen leeuw vanderzee, heer Antonio van Diemen, vice reij vande Hollanders in India : ick hebbe zeer grootelijck aen UE. begeert op het goet vertrouwen dat ick van UE. maecke, om int moesson van September door UE. een vloote gesonden te werden met groote macht voor de bharre van Goa; ick sall vangelijcke aldaer te landen zenden een secours van voleq te paerde ende te voeth, opdatse met de Portugiesen cloeckmoedichlijck vechten ende de stadt van Goa veroveren met haere

${ }_{1}$ De kaarten zijn niet steeds nauwkeurig: b.v. Chaul was Portugeesch b.v. in 1636 (Dagh-Register 1636, bldz. 273).

2 Op een andere plaats: (bldz. 253) ${ }_{n}$ Idara". Gewoonlijk genoemd: Mohammed Adil (Gribble, Deccan, p. 210). 
landen ende dat hij d'selve stadt met haere landen aen mijn gouverneur ende capiteijnen in doen leveren. ${ }^{1}$

Ende ick sal aende Hollanders doen geven een plaetse in mijn landt, om te gaen en comen tot verrichtinge van haere coopmanschappen ende handelinge, sonder verbonden ofte gedwongen te wezen door eenige persoonen ende arriveerende d'selve Hollanders in mijne havenen, sall ick ordre geven aen mijne gouverneurs ende cappiteijnen, dat zij d'selve sullen favoriseeren ende behulpich zijn, haer gevende alle noodicheeden soo van eeten, drincken als andere zaecken totten oorloghe. ${ }^{1}$

Ende overmits de Portugiesen 't contract vande pays, ende d'oude vruntschap die met hen gehadt, gebroocken hebben, soo geeve ick aende selve Hollanders oorloff, om in alle mijn voorschreven landen te comen ende leverende d'selve Hollanders aen mij d'voorschreven stadt van Goa met haere landen, soo sal ick gehouden zijn aen haerlieden te geven de helft vande incompste ende gerechticheeden, mitsgaders een plaetse waer dat zijlieden sullen gelieven, ofte inde stadt van Goa, ofte in andere mijne havens, waer dat sullen begeeren, int welcke sijlieden moogen verseeckert zijn, met goet vertrouwen ende comen tegen toecomende jaer voor de bharre van Goa. Ende dit contract 't welck ick met haer lieden gemaeckt hebbe, sal van waerden zijn gelijck hetgeene dat den coninck Sicander ${ }^{2}$ gemaeckt heeft ende ten geenen tijden en sal ick daertegen gaen ende altijt 't selve naer comen.

Gedaen inde maent genaempt Soual 1046. ${ }^{3}$

\section{AMBON.}

1 Juni 1637. 4

De gevangenneming van Kakiali door Van den Heuvel in Mei 1634 en de daarop gevolgde gebeurtenissen (zie contract $n^{\circ}$ CIX) hadden zeker

${ }^{1}$ In December 1637 is Van Twist weder naar Bijapoer vertrokken. De sultan wilde toen niets meer van een gezamenlijk optreden tegen Goa weten, onder voorgeven dat wij te laat daar waren verschenen. De onderkoopman Paets had inmiddels de belangen der O. I. C. in genoemd rijk behartigd (onuitgegeven missives van Van Twist).

${ }^{2}$ Hiermede moet bedoeld zijn Ibrahim Adil (1579-1626), de eenige voorganger van Mohammed Adil, met wien de onzen in aanraking kunnen zijn gekomen. De zaak is mij echter niet duidelijk.

3 Sjawwâl 1046 loopt van 26 Februari tot 27 Maart 1637.

4 Uit het Contractboek. 
niet gestrekt, de rust op de Ambon-eilanden te herstellen; het wantrouwen en de hat tegen de Nederlanders werden vergroot (Vgl. TieleHeeres, Bouwstoffen, II, bldz. LIX, v.v.). Zoo min als Van den Heuvel mocht het diens opvolger, Jochem Roelofszoon van Deutecom (1635-1637), of den commissaris Artus Gijsels (1635) gelukken, de rust te herstellen. De zaken kregen in 1636 zoo'n ernstig aanzien, dat de gouverneurgeneraal Van Diemen besloot, zelf naar die streken te vertrekken, waar hij in Januari 1637 aankwam. Na eerst forsch te zijn opgetreden en met succes, nam Van Diemen een verzoenende houding aan. Om Hitoe te winnen, herstelde hij Kakiali in zijn waardigheid, waarop deze en andere Hitoesche hoofden onderstaand contract teekenden.

Contract met die van Hittoe vernieuwt ende geamplieert.

Allsoo de jngesetenen van Hittoe door maght ende middelen van de Generaele Nederlandsche Comp $p^{e}$ in den jare 1605 verlosst ende vrijgestellt zijn uijt het gewelldt ende tijrannije van de Portugesen, onse allgemeijne vijanden, ende door desellve wederom gebraght in het vrij besitt ende gebruijck van hare goederen, landen ende steden, uijt welcke te vooren bij de Portugesen waren verdreven; ende dat in recompense van zoo groote welldaden bij verscheijde contracten ${ }^{1}$, verbintenissen ende eeden de voorschreven jngesetenen van Hittouw haer sellven vrijwillighlijck hebben onderworpen ende verbonden aende Hoge Mogende Heren Staten Gener ${ }^{1}$ der Vereenighde Nederlanden ende andere ${ }^{2}$ gemelte $\mathrm{Comp}^{\mathrm{e}}$, maer dat bij verloop van tijden deselve contracten, verbintenissen ende eeden bynae als vergeten ende jn veelen verbrooken zijn geworden;

daer benevens dat bij versterven van den ouden capiteijn Hittou ${ }^{3}$ des selffs soone Cackij Alij in Junij 1633 opt voordragen der Hittoese hooffden in des overledens plaetse, op d'approbatie van den Gouvern ${ }^{\mathrm{r}}$ Generael, als hoofft ende $\mathrm{Cap}^{\mathrm{n}}$ Hittoe is gestellt geworden ende dat geseijden Kackij Alij naderhandt is beschulldight, voornemens te zijn den standt van de Nederlandsche Compagnie te ruijneren, t'landt van Amboijna ende Hittoe te parturbeeren ende van desselffs goede vreede te berooven ende ten verderve te brengen, waerop in Maijo $A^{\circ} 1634$ bij den Vice Gouverneur Anthonie van der Heuvell gevangen is genomen ${ }^{4}$ ende naderhandt tot $\mathrm{B}^{\mathrm{a}} \mathbf{5}$ gevoerdt, waerdoor

1 Vgl. hiervóór, bldz. 258, noot 2.

2 Schrijffout voor: "aen de".

3 Vgl. hiervóór, bldz. 258.

4 Vgl. hiervóór, bldz. 262, v.v.

5 Batavia. 
't sedert meer onlussten onder d'jnwoonderen van Hittoe geresen zijnde, sulcx dat hun alle, except d'jngesetene op Hittoulamma ${ }^{1}$ ende het dorp bij de reduijt Hittoe, sorteerende onder den oranghcaij Boelangh ${ }^{2}$, van den Nederlandtschen staet hebben gesepareerdt ende op de hooghste ${ }^{3}$ gevlught zijn, refuseerende den orangkaij Caijouwan, te vooren bedient hebbende t'ampt van Tanahitoumessingh, bij den $\mathrm{H}^{\mathrm{r}}$ gouvern $^{\mathrm{r}}$ generael Henrick Brouwer ende de raden van Judia in $\mathrm{B}^{\mathrm{a}}$ tot $\mathrm{Cap}^{\mathrm{n}}$ Hittou gecreerdt ${ }^{+}$, daer voor te willen erkennen nogh aen te nemen; te meer desselffs qualificatie, zoo voorgeven, d'ordre ende stijll der regeringe des landts Hittoe is contrarieerende; ende dat de hooffden van Hittoe generalijcken in verscheijden onderhandelingen seer jnstantelijck aen den Gouvern ${ }^{r}$ Gener $^{1}$ ende zijne Raden hebben versoght ende gebeeden, men willde voorschreven Caijkij Alij, die weder van Bat ${ }^{\mathrm{a}}$ jn Amboijna hebben gebraght, in voorige vrijdom ende qualiteijt herstellen, belooven[de] dat haer als goede bondtgenooten sullen comporteeren, 't verbandt ende contract, voor desen met den Nederlandschen staet aengegaen, [in] alle getrouwigh ${ }^{t}$ naercomen ende doen observeren.

Den Gouvern ${ }^{\mathrm{r}}$ Gener $^{\mathrm{l}}$ ende de raden van Jndia, genegen zijnde tot bevorderingh van des landts Hittoes russte ende eenigh ${ }^{t}$, hebben geseijden Cackij Alij gelargeerdt den $20^{\mathrm{e}}$ Meij passado ende heden opt het voordragen ende versoek van den koninck van Hittoe ${ }^{5}$, de vier opperhooffden, mitsgaders alle de mindere hooffden van [het] Hittoese landt, bij ons allhier int cassteell Victoria verschenen ende vergadert zijnde, den gemelten Kackij Alij herstelt, tot Capiteijn aengenomen ende geauthoriseerd ende in contra den bij ons gemaeckten $\mathrm{Cap}^{\mathrm{n}}$ Hittoe, Oranghcaij Caijjouwan, van zijn Capiteijns ampt ontlast ende in zijn voorige qualiteijt van Tanahittouwmessingh gestelt, mitsgaders als Orancaij Tauwa ${ }^{6}$ gequalificeerd. Jnvoegen dat wij [bij] desen tot bevorderinge van de gemeene ruste stellen ende committeeren als geseght tot $\mathrm{Cap}^{\mathrm{n}}$ Hittoe den Oranghkaij Kackij Alij onder expresse conditien, dat alle voorgaende contracten, verbonden ende accoorden tusschen den Vereenighde Nederlandschen staet

1 Hitoelama aan de Noordkust van Hitoe.

2 Zie over hem b.v. Bouwstoffen II, bldz. 282.

s Valentijn, Ambon, bldz. 114: "hoogte".

4 Bouwstoffen, II, bldz. LXI, 266, 273, 282, 304.

5 Vgl. hiervóór, bldz. 263, noot 1.

- Bij Valentijn, II, b, bldz 114, waar het contract is opgenomen: „Orankay Toewa" (Oudste orangkaja). 
ende die van Hittoe opgereght, van nieuws geconfirmeerdt ende bevestight sullen worden ende dat den voorschreven Kackij Alij als Capiteijn ende opperhoofft, mitsgaders de vier principaale hooffden, den koninck van Hittoe ende alle andere smalle hooffden, onder het gebiedt van Hittoe sorterende, met solemnelen eede sullen verclaren ende belooven, de voorschreven contracten onverbreekelijcken te houden ende t'aghtervolgen, gelijck deselve hier nae volgen ende uijtgedruckt zijn.

Soo hebben op 't versoek van den geseijden Cap $^{n}$ Hittoe, de vier hooffden deszelffs landts ende den radia Hittoe gequalificeerdt Telouca ${ }^{1}$ van Capaha als Touban Bessij.

Eerstelijck dan zoo beloofft en zweerdt Cackij Calij, als opperhoofft ende Capiteijn van Hittoe, voor hem ende sijne ondersaten, als mede Caijouwan in qualité als Tanahitoumessingh ${ }^{2}$ ende Oranghcaija Tauwa, Solice als Tata Hatouw ${ }^{2}$, Barus ende Nossitapij $^{3}$ ende Barmaille ${ }^{*}$ in qualite van Patij Touban ${ }^{2}$, Hongij Lammij, 5 Coninck van Hittoe, jtem alle de mindere hooffden van 't landt Hittoe voor haer ende hare onderdanen, gelijck sij samentlijck heden volgens haer gebruijck op den Mossaphij off allcaron ${ }^{6}$ gezwooren ende belooffdt hebben:

dat zij de Hooge Mogende $\mathrm{H}^{\mathrm{n}}$ Staten Generael, Zijn Princelijcke Ex ${ }^{\text {tie }}$ ende de Bewindhebberen van de Vereenighde Nederlandsche Comp ${ }^{e}$ ende hier te lande den $\mathrm{E}^{\mathrm{d}} \mathrm{H}^{\mathrm{r}}$ Gouvern ${ }^{\mathrm{r}}$ Gener $^{\mathrm{l}}$ ende raden van Jndia, voorall ende jnzonderheijt den gouvern ${ }^{\mathrm{r}}$ van Amboijna, in alles gehou ende getrouw zullen zijn; daer beneffens zweeren ende belooven, dat zij denzellven tegens alle hare vijanden offte die haer Edel ${ }^{\mathrm{n}}$ beoorlogen te water offte te lande sullen hellpen, bijstaen ende assisteren, selffs tegens de Tarnataensche quimelahas 7 ende alle hare adhaerenten, soo lange deselve vijandelijck tegens ons procedeeren, nae uijtterste vermogen met goedt ende bloedt, gelijck getrouwe bondtgenoten ende vrunden schulldigh zijn en conveneerdt.

1 Zie over hem b.v. Bouwstoffen, II, bldz. 316 en III, passim.

2 Vgl. hiervóór, bldz. 156, noot 1 .

3 Valentijn heeft juist: Baros als Noesatapi. Vgl. Valentijn, Ambon, a, bldz. 96.

Noesatapi is een der 4 hoofden van Hitoe.

4 Valentijn: Barmella.

${ }^{5}$ Valentijn: Hongi Lamoe.

${ }^{6}$ Moeshaf, het Boek, de Koran.

7 Valentijn heeft minder juist: „Ternataanen, Kimelaha's, ende,”. 
Ten laessten zoo zweeren ende belooven [zij] aen niemandt anders eenige giroffel nagelen te verkoopen dan aen de cooplieden van de Generale Compe, die deselve op Hittoe sullen moeten ontfangen, zonder dat die van Hittoe gehouden zijn, de nagelen aen 't Cassteell ${ }^{1}$ te leveren;

daer beneffens is goedgevonden ende tusschen de Generale Comp ${ }^{e}$ endde die van Hittoe besloten, dat ijder zijn geloove zal vrij houden ende niemandt ter wederzijden daerinne zall werden gemolesteerd.

Soo een dienaer van de Comp ${ }^{e}$ verliep ${ }^{2}$ ende jnt gebiedt van Hittoe hem verstack, sullende de jngesetenen van Hittoe op 't versoeck van den $\mathrm{H}^{\mathrm{r}}$ Gouvern ${ }^{\mathrm{r}}$ soodanigen wederom ter handt stellen, gelijck haerluijden overgeievert zullen worden die uijt de haren bij het Cassteell bevonden ende weggelopen zullen wesen.

Eenige dienaers van de Comp ${ }^{e}$ de jngesetenen van Hittoe overlastst doende, zullen naer exigentie van saken bij de $\mathrm{H}^{\mathrm{r}}$ Gouvern ${ }^{\mathrm{r}}$ worden gecorrigeerdt.

Indien ijmandt van de ondersaten van Hittoe een Chrissten, t' zij man offte vrou, onder pretext van huwelijck zonder consent ende voorweten van den $\mathrm{H}^{\mathrm{r}}$ Gouvern $^{\mathrm{r}}$, tot het Moorsdom braghten, zall zoodanige voor d'eerste rijs verbeuren duijsent patoolen ten profijte van de Generale Comp ende sullen de Christenen, die eenige Moorse vrouwen van Hitoe halen sonder consent als vooren, in gelijcke peene vervallen ende wie bevonden wordt voor de tweede reijss 't selve gedaen te hebben, zall zonder genade aen den lijve gestrafft worden.

Jngevalle den $\mathrm{H}^{\mathrm{r}}$ Gouvern ${ }^{\mathrm{r}}$ die van Hittoe tot eenige wercken ten dienste van de Comp $^{e}$ ende tot pangaijen deede voorderen, sullen sonder eenigh tegenspreeken daertoe hellpen, mits dat die van Olijsiva ende Olijlijma te zamen tot zoodanige werken ende tot pangaijen zullen werden geroepen.

Waertegens $d^{\prime} \mathrm{H}^{\mathrm{r}}$ Gouvern $^{\mathrm{r}}$ van wegen de Hoge Mogende $\mathrm{H}^{\mathrm{n}}$ Staten Generael, Zijn Princellijcke Ex ${ }^{\text {tie }}$ ende de Generaele Comp ${ }^{e}$ ter presentie ende door d'last van de $\mathrm{Ed}^{\mathrm{e}} \mathrm{H}^{\mathrm{r}}$ Gouvern $^{\mathrm{r}}$ Gene ${ }^{\mathrm{rl}}$ beloofft heefft, den voorschreven Cackij Alij als Capiteijn ende opperhoofft, mitsgd ${ }^{\mathrm{rs}}$ alle d'andere Oranghcaijen en jngesetenen van Hittouw als haer eijgen natie tegens alle hare vijanden te water ende te lande

1 Victoria.

2 Valentijn: „overliep". 
te hellpen, bijstaen ende defenderen, daer den noodt sulcx is vereijschende.

Jtem dat [wij] den prijs van den rijs ende eenige kleeden wat civijler als tot nogh toe sullen doen stellen, daervan bij den Gouvern ${ }^{r}$ eerstdaegs een lijsste zall worden geconcipieert tot reglement van onse cooplieden, waertegen dat aennemen ende belooven, de nagelen suijver ende volgens contract, als voor deesen jn gebruijck is geweest, te leveren ende sall ter wederzijden zoowell bij de leveraer als den ontfanger geen fraude int gewighte mogen gedaen worden, maer ijder laten genieten dat hem reghtelijck toecompt.

Soo heefft den Gouvern ${ }^{\mathrm{r}}$ Generael mede aengenomen te bevoorderen, dat met passen uit $B^{a}$ zullen varen nae 't landt Hittoe, omme op Hila voor de reduijt te ankeren ende nergens anders, de Chineesen, Maleijers ende andere natien met hare coopmanschappen, daer van $\mathrm{d}^{\prime}$ Comp $\mathrm{p}^{\mathrm{e}}$ een toll van $10 \mathrm{p}^{\mathrm{r}}$ cento zall trecken, namentlijck 5 van de aenbrengende coopmanschappen ende $5 \mathrm{p}^{\mathrm{r}}$ cento van de waren ende comptanten, die uijt voeren, mits dat onse visitatie sullen moeten gedoogen ende geen nagelen vervoeren op pene van lijff ende goedt te verbeuren.

Zoo zullen ook nae exigentie van zaken met advijs van $d^{\prime} H^{r}$ Gouvern $^{\mathrm{r}}$ in Amboijna gestrafft worden d'jnwoonders van Hittoe, die bevonden sullen werden secretelijck hare nagelen aen andere als die van de Nederlandsche Comp ${ }^{\text {e }}$ vercoght off gebraght ${ }^{1}$ hebben te vercopen, blijvende de nagelen verbeurt ten proffijte van de aenbrengers ende hooffden des landts van Hittoe.

Alle welcke conditien, verbonden ende contracten bekennen voorschreven oranghkaijs van Hittoe, ten aenhooren van alle smalle hooffden ende hare meesste onderdanen, ten principale te wesen d'oude ende selve contracten, poincten ende artijculen, daermede van oudts aen den Generalen Nederlanschen staet ende Comp ${ }^{e}$ zijn verbonden, die zij ook belooven getrouwelijck naer te comen. Ten oirconde hebben dit onderteijckent.

Actum Amboijna int casteell Victoria, primo Junij $\mathrm{A}^{0} 1637$. Was onderteijckent Anthonio van Diemen, Anthonio Caen, Joan Ottens, Joghum Roeloffsen ${ }^{2}$.

Hingilano, radia Hietoe; Kachialij, capiteijn Hittoe; Kaịjovan, Tanahietoemessingh ende Oranghkaij Toua; oraugkaij Baros;

1 Valentijn: "getragt".

2 Van leutecom. 
Soulisa, Toutoehatoe; Barmaylle, patij Touban; Talouki, oranghkaij van Capaha ${ }^{1}$. Ende ter zijden gesegellt met het zeegell van de Compe.

\section{MAKASSAR.}

\section{Juni 1637. 2}

Met Makassar (Gowa), met welks vorst wij sedert het begin der $17^{\text {de }}$ eeuw (1609) in commercieele en staatkundige aanrakingen waren gekomen (vgl. de Jonge, Opkomst, III, bldz. 102, 319, v.v.), waren de betrekkingen niet steeds van aangenamen aard gebleven. Onze handelspolitiek, vooral ten opzichte van de Ambon-eilanden, dreigde Makassar te berooven van de voordeelen, welke het trok uit de negotie op die streken. Verder trachtte de Sultan zijn macht en invloed uit te breiden, b.v. op Boeton, op de Kleine Soenda-eilanden en mèt zijn politieke macht den invloed van den Islam. Ook in dit streven stootte hij op het voortdringen der Nederlandsche staatkunde en eenigermate op de Nederlandsche Christenpropaganda (Vgl. Tiele-Heeres, Bouwstoffen, II, bldz. XX, v.v., enz.). De tegen ons gezag in verzet komende Ambonners werden openlijk of in 't geheim door de Makassaren gesteund. Bij zijn bezoek aan het Oosten van den Archipel in 1637 heeft Van Diemen ook Makassar aangedaan en de onderlinge geschillen trachtte men bij te leggen door middel van onderstaand contract (Vgl. Bouwstoffen, II, bldz, LXVI, v.v., en 324; DaghRegister 163\%, bldz. V, 280, v.v., waar ook het contract is opgenomen).

Conditien, bij den $\mathrm{ko}^{\mathrm{k}}$ van Macassar op het treffen van de vreede tusschen Zijne Maij ${ }^{t}$ ende $d^{\prime} E d^{e} \mathrm{H}^{\mathrm{r}}$ Antonio van Diemen, gouvern ${ }^{\mathrm{r}}$ gener $^{\mathrm{l}}$ over den Nederlandtschen stant in Orienten, voorgestelt, ende zijn ende zijn $\mathrm{Ed}^{\mathrm{t}}{ }^{3}$ met eenige ampliatien den anderen voorgehouden ${ }^{4}$ geapprobeert, luijdende als volght, namentlijck:

Dat de Nederlanders vermogen zullen, zoo langh hier een off meer schepen ter rheede hebbende ${ }^{5}$, een huijs aen land in huijr te nemen ende daer in haer volck te leggen;

1 Volgens Valentijn, II, b, bldz. 115, teekenden de radja Hitoe en patih Toeban (en orankaja Baros?) met een merk; de overigen met hunne namen.

2 Uit het Contractboek.

${ }^{3}$ De zin is hier niet geheel zuiver.

4 Over deze onderhandelingen zie men het Dagh-Register t. a. p.

${ }^{5}$ Het Dagh-Register heeft: "hebben". Dus geen vaste factorij. 
dat ${ }^{1}$ hem in zijn rijck geensints sullen mogen beschadigen, allsoo tegen de Nederlanders geringh van maght zeght te wesen;

dat de Nederlanders ook gedurende desen vreede niet vermogen zullen, tegen Zijne Maijt ${ }^{t}$ nogh niemandt ${ }^{2}$ onder des selfs gebiet sorterende vijandtlijckheijdt te betoonen, behoudens dat [zij] desselffs subjecten in onvrij vaerwaters, te weten omtrent Malacca, op de cust van Ceram etc ${ }^{\text {a }}$ sullen vermogeu als vijanden aen te tassten ende te nemen, 't welck aen dit tractaet geen jnfractie zall veroorzaeken ;

dat om particuliere questie met ijmandt van de zijne geen verbrekingh van vrede comen, maer op't gevoeghlijkste gemodereerdt werden zall;

dat alle voorvallende questien tusschen de Nederlandsche eude d'Engelschen, Deenen, Portugeesen ${ }^{3}$, Maccassaren, etc ${ }^{a}$ bij de Maijt affgedaen zall worden, mits dat het presente Nederlandts opperhoofft mede in sijn raedt sall compareren; ${ }^{4}$

dat zijn rheede ongevioleerdt zullen laten, juvoegen dat de Nederlanders daer niemandt van hare vijanden sullen mogen aentassten ende ook gelijcke vrijheijdt genieten;

dat bij alldien de Spangiaerden, Portugesen off eenige andere vijanden van de Nederlanders te deser rheede soo maghtigh quamen, dat eenige harer schepen off jaghten tegens des Maij ${ }^{\text {ts }}$ will overwelldight wierden, hem allsdan de schullt niet sullen geven, allsoo sulx ter zee niet beletten en kan, mits dat de Nederlanders op gelijcke maniere bij gelegentheijdt hare revenge sullen mogen nemen; dat ijder met zijn vijandeu zall aenspringen, 5 sonder gehouden te wesen den anderen te assisteren, off te ware sulx uijt lieffde deden, behouden dat de Nederlanders t'allen tijde haere geallieerde tegens onbehoorlijjcke overlasst moeten protegeren;

dat van beijde zijde geen vreemde praetjens offte uijtstroijselen, die den gemaeckt vreemde ${ }^{6}$ eenighsints hinderlijck moghten wesen, lightelijck sullen aennemen;

dat tot gereghtigheijdt voor Zijne Maijt van alle uijtroerende waeren betalen sullen, namentlijck

1 Dat de Nederlanders hem, enz. De versehillende artikels zijn oorspronkelijk opgesteld door den Sultan (Dagh-Register, bldz. 286).

2 Dagh-Register: imandt.

3 Al deze Europeesche natiën dreven op Makassar handel.

4 Dit was een twistpunt bij de onderhandelingen (Dagh-Register, bldz. 286, v.).

5 Dagh-Register: omspringen.

- Dagh-Register: vreede. 
van de cojang ${ }^{1}$ rijcx ${ }^{2} 2$ coupan $^{3}$ off $\frac{1}{2}$ maes $^{3}$ is $\frac{1}{2} \mathrm{R}^{\mathrm{a}}$ Spaens 4 nagelen $\mathrm{p}^{\mathrm{r}}$ bhaer $52[\mathrm{maes}]$. . . . . . " $2 "$ " $"$ " sandelhoudt . . 1 . . . . . . . " $1 "$. . " schillpadtshoorn . 4 . . . . . . . . " 4 . 4 . wasch . . . 1

ende van de resterende waren zoo veell als d'Engelschen, Deenen Portugeesen, etc ${ }^{\mathrm{a}}$ tot toll betalen;

dat bij alldien eenige Nederlanders op Maccassar quamen wegh te loopen, deselve aen haer meesters weder ter handt stellen zullen, gelijck ook eenige Maccassaren bij de Nederlanders allsoo overcomende, aen Zijne Maijt restitueeren moeten;

dat ijder zijn gelooff zall vrij hebben, sonder daer in eenighsints geconstringeerdt te werden.

Ter zijde stondt: Nota, dat den coninck van Maccassar bij dese bovenstaende artijkelen jn Maleytse tale heefft doen bijvoegen, dat successeurs van de presente gouvern ${ }^{r}$ gener $^{1}$ desen getroffen ${ }^{6}$ niet sullen mogen verbreeken. ${ }^{7}$

Ende nogh lager, onder t zeegell: dit is het chiap offte zeegell des konings van Maccassar. Datum als vooren ${ }^{8}$ ende was geteeckent Pieter Mestdagh. ${ }^{9}$

Alldus gedaen ende geslooten bij den coninck van Macassar

1 Inhoudsmaat met verschillend gewicht (Vgl. b.v. Valentijn, Batavia, bldz. 369, v.; Encyclopaedie, II, bldz. 277, 473, enz.; Van der Chïs, Plakaatboek, XVII, no 7467).

2 Dagh-Register: rijs.

3 Ook de waarde dezer munten variëerde (Vgl. b.v. Valentijn, t. a.p., bldz. 356).

4 Dagh-Register: ra van achten Spaens gelt.

${ }^{5}$ Een baar te Makassar kwam niet geheel in gewicht overeen met die op Ambon b.v. (Valentijn, t.a.p., bldz. 360, enz.).

- Dagh-Register: getroffen vreede.

7 Vgl. over deze nota Bouwstoffen, II, bldz. 324; Dagh-Register, bldz. 287 : nalsoo bij experiëntie (soo voorgaven) bevonden hadden, dat bij vertreck ende veranderingh der Nederlanders Generaels de woort-contracten niet gemainteneert wierden ...." Omgekeerd vertrouwden de Nederlandsche autoriteiten den Sultan zóó weinig, dat, toen in 1651 geschillen rezen over de tenuitvoerlegging van de alinea omtrent overloopers en bleek, ${ }_{n}$ dat het contract in 't Maleijts onder hen berustende, dat poinct aengaende, van het Nederlants tenemael differeert," de Nederlanders twijfelden, of het hun vertoonde exemplaar wel "d'originele acte zelfs zij geweest" (Vgl. Onuitgegeven Generale missive 19 Dec. 1651 en rapport-De Vlamingh).

8 Geheel deze alinea had onder de volgende moeten staan. Vgl. DaghRegister, bldz. 289.

? Secretaris van den GG. op dezen tocht.

7• Volgr. III. 
ende $\mathrm{d}^{\prime} \mathrm{H}^{\mathrm{r}}$ Anthonio Caen, extraordinaris raedt van Indien, gecommitteerdt wegen den gouverneur generael boven genoempt, op den strandt van Macassar, desen $26^{\text {en }}$ Junij $A^{\circ} 1637$ ende is Zijn Maij ter handt gestelt copie deser artikelen, bij den Gouvern ${ }^{\mathrm{r}}$ Gener ${ }^{\mathrm{l}}$ ende d'Ed. Anthonio Caen jnt schip Oudewater ouderteekent, te dage ende jare als vooren.

\section{BANDA.}

\section{December 1637. 1}

Cornelio Acoley, gouverneur van Banda (1633-1642) 2, „nam in 't jaar $1634^{3}$ die van 't gespanschap Cottaroewa..... als ook die van 't eiland Goram, vreezende 's Compagnies gansche magt op hun dak te krijgen, na veel biddens en smeekens, weer in genade aan, maakende met hen dit navolgende geschrift van verzoening" 4.

Wy Cornelis Acoley, Lantvoogt en Bestierder wegens den Nederlandschen Staat in Banda, onder het beleid van den Edelen Heer Antonio van Diemen, Opperlandvoogt van gansch Nederlands Indiën, doen te wêten, hoe dat op 't ernstig bidden en ootmoedig verzoek der expresse daar toe gecommitteerde Opperhoofden, genaamt Hatalima, Labacuda, Comboret, Kaywan, Manika, Tibo, Labi, Maleyo, en Tatollo, van de respective Dorpen Catelove, Ammer, Day, Ondei, Aineckor, Kelacket, Mieren, Minda en Kelessiter, alle gelegen op 't eiland Goram 5; na goed berigt en onderhandeling, tot distincte reizen gehouden, waar in de voor dezen bedrevene fouten levendig zyn vertoont, invoegen na schuldbekentenis en fidelle beloften van tot geenen tyde iets tegen de Nederlanders, of derzelver Staat, nu, nogte nimmermeer, in 't klein of 't groot te zullen attenteren, veel $\min$ te dulden, de geringste onlusten ons van hen niet zullen worden aangedaan, maar in-tegendeel te verzorgen, dat ons van hen alle hulp en faveur, gelyk zulks een getrouwe vasal betaamt, zal worden betoont, en dat wy in alles worden gehoorzaamt, waar

1 Overgenomen uit Valentijn, III, 2 (Banda), bldz. 89.

2 Tiele-Heeres, Bouwstoffen, II, bldz. LXXIII.

3 Drukfout voor 1637 vermoedelijk.

4 Ik neem deze zinsnede over uit Valentijn, t.a.p., voor wiens rekening ik dit alles laat; mijn onderzoek heeft mij niets omtrent dit contract of zijne totstandkoming geleerd.

${ }^{5}$ Vgl. hiervóór, bldz. 200, 201. Enkele plaatsnamen zijn goed te herkennen: Ondor, Kailakat, b.v. 
op zy dan van de Nederlandsche Geoctroyeerde Oostindische Compagnie en des zelfs Regenten in dit vredeverbond weer aangenomen worden, weshalven hen om verscheide inzigten, ons daar toe moverende, haar vorig bedryf niet alleen vergeven is, maar waar op wy ook nader met advys van onzen Raede met hen in alliantie en een eeuwig verdrag getreden zyn, en hen als onze bondgenooten en getrouwe vrienden, op de volgende conditien, aangenomen hebben, gelyk wy de zelve aannemen, en daar voor erkennen mits dezen; dienvolgende beloven, en sweeren de gemelde Orangkaja's van Catelove, Ammer, Day, Ondei, Aineckor, Kelacket, Mieren, Minda, en Kelessiter, voor haar, en haare erfgenaamen, de E. Hoog Mog. Heeren Staaten Generaal der Vereenigde Nederlanden, Zijn Vorstelijke Genade, den Prince van Orangie, als haare hoogste Souveraine Overigheid, item der zelver Generaal, en den Gouverneur der quartieren Banda, gehouw en getrouw te zullen zyn tot den laatsten adem toe, onder welken eed de gemelde Orangkaja's toezeggen, en beloven, 't effect tot allen tyden te zullen doen stand grypen; dat zy lieden de minste correspondentie met geene vyanden van den Staat, hoedanig, van wat conditie, natie, of natuure, dezelve ook zouden mogen wezen, niemant uitgezondert, houden, en veel min hen hunne havens, of rheeden tot schuilplaatzen verleenen, of de minste faveuren bewyzen; maar dat zy dezelve met alle mogelyke middelen van daar weeren, en zulks den Heer Gouverneur van Banda na de beste gelegenheid te kennen geven zullen. Item, dat, by verloop van slaaven, en andere, de zelve onder ordinair bergloon en verteerde kosten, in redelykheid bestaande, zonder eenige frivole extensien, in handen van gemelten Heer Gouverneur leveren, en haar best, zoo veel hem mogelyk is, zullen zoeken te bevorderen, gelyk zy hen ook ten hoogsten verbonden houden op het bevel van meer gemelde Heer Gouverneur (doch niet dan by den uitersten nood) haare coracora's in 't water af te haalen, en hem, beneffens zyn Eds magt, in alle getrouwheid, zonder tegenzeggen, te dienen; en dit alles op paene van als Eedbrekers en Rebellen gestraft te worden; voor 't welke de meergemelde Orangkaja's benevens hunne ingezetenen der bovengenoemde Negryen den vryen gepermitteerden handel op Banda, als mede op alle geassocieerde Nederlandsche plaatzen, onder een behoorlyke passe, genieten, gelyk wy hen ook alle vriendschap zullen doen smaaken, en hen onder onze bescherminge nemen, zoo als dat een getrouw Heer, en goedertieren Vorst betaamt, en met onze constitutien eenigzins overeenkomen zal. 
Gearresteert in het kasteel Nassau, op 't eiland Neira in Banda, den $28^{\text {sten }}$ December 's jaars 1637. Was geteekent Cornelis Acoley. Ter zyden stonden eenige Arabische Merken, gestelt by de ondergeschreven Orangkaja's Batalima. Labacuda. Comboret. Caywan. Manika. Tibo. Labi Labi. Maleyo. Tatallo.

\section{CEILON.}

\section{Mei 1638. 1}

In de eerste jaren na de verdragen van 1610 en 1612 (No XXXVI en XLI) hadden de betrekkingen der Nederlanders met Ceilon weinig beteekend, terwijl het den Portugeezen gelukte zich steeds vaster op het eiland te vestigen, in de hoop, de Westersche mededingers uit den handel dáár te sluiten; en ofschoon dit natuurlijk niet ging zonder strijd, mocht het den Maharadja van Kandy, die tevens zich als vorst over geheel Ceilon beschouwde, niet gelnkken, de Portugeezen te verdrijven. Na den dood, in 1632, van den toenmaligen maharadja, wist een zijner zoons, na binnenlandsche troonsopvolgingstwisten, den troon te veroveren en zich er op te handhaven. Hij bestaat bekend als Radja Singa. Eénheid bracht hij in 't inwendig bestuur; den vreemden indringer wilde hij uit zijn land weren. Daartoe zocht hij te kwader ure hulp bij de vijanden der Portugeezen, bij de Nederlanders. Deze (Van Diemen stond aan hun hoofd) gingen op dit denkbeeld in, dat zoo volkomen strookte met geheel hun optreden tegen de Portugeezen in die deelen van Azië (Vgl. hiervóór, bldz. 294 v.). De hulp werd verleend en de toekomstige verhoudingen werden bij onderstaand voor de Nederlanders zoo voordeelig contract geregeld (Van Geer, Ceilon, bldz. 23-42; Baldaeus, Ceylon, bldz. 45 v.v., waar deze overeenkomst op bldz. 56 v.v. is afgedrukt, echter verkort en dus niet in de oorspronkelijke termen ${ }^{2}$ ).

Accoordt ende contract door d'E. Adam Westerwollt, extraordinaris Raedt van Jndien ende Command ${ }^{r}$ over de presente navale maght van schepen, solldaten en matroozen, mette amonitie van oorloge voor de toght van Ceijlon versien van wegen de doorlughtige Hoge Mogende $\mathrm{H}^{\text {ren }}$ Staten Gener ${ }^{1}$ der Vereenighde Nederlanden, Zijne Princelijcke Exce Fredrick Hendrick, Prince van Orangien etc ${ }^{\mathrm{a}}$, in dienst van d'E. $\mathrm{H}^{\text {ren }}$ Bewinthebberen der Vereenighde Oostjndische Compe, op approbatie ende goedtvinden van d'Ede $\mathrm{H}^{\mathrm{r}}$ Gouvernenr Generael ende de Raden van Jndia, ter eenre; ende de door-

1 Uit het Contractboek.

2 In het Contractboek Zeeland bevindt zich ook een exemplaar. 
lughtige hoogchgebooren radja Singua, Keijser ende Coninck van Seijlon ende Candien etc ${ }^{\mathrm{a}}$, met sijne onderdanen des rijcx, staende onder de croone ende gehoorsaemheijt van zijne voorschreven Keijserlijcke Maijt, ter andere zijde, aengegaen ende besloten, in forma ende manieren als hier naer volght: d'welck sall eeuwigh duijren.

1.

Eerstelijck dat Sijne Keijserlijcke Maijesteijt, Coninck van Ceijlon ende Candien, ende zijue ondersaten ons alls vrunden, bondtgenoten ende beschermers zijns rijcx tegens zijnen ende onsen allgemeenen vijandt, den Portugees, erkennen, accepteren ende aenneemen, om zijne landen van Zeijlon te hellpen verdefendeeren ende beschermen tegens de groote onverdragelijcke ontrouwe, overlasst ende onheijlen der Portugesen int incorporeren sijner landen, domeijnen ende heerlijcken. ${ }^{1}$

2.

Eenige sterckten van forten, als Batecalo ${ }^{2}$ offte eenige andere vastigheden, daer ontrent gelegen, door ons ${ }^{3}$ met Zijne Maij ${ }^{t}$ hullpe ende maght jngenomen en geconquesteerdt werdende, 't zij met accoordt offte gewellt, sullen all de buijt ende goederen, daer in vindende, halff en halff werden gedeellt.

3.

Bij soo verre 't gebeurde, als verhaellt, eenige van de bovenstaende forten, fortressen offte sterkten, waer ter plaetse sulcx moghte comen te geschieden, bij ons ende Zijne Keijserlijcke Maijt quamen te veroveren ende te incorporeren, dat wij lieden alsdan deselve veroverde sterckten met crijghsofficieren, solldaten, geschut ende ammunitie van oorlogh tegen des aenstaende vijandts maght der Portugesen sullen besetten; ende ons oordeells de gemelte starcten niet bestant, bequam ende defensijff genogh aghten te wesen, om den vijandt te connen wederstaen, sall als dan Zijne Maijt gehouden wesen op zijn eijgen cossten de voorschreven sterckheijt ${ }^{*}$ offte plaetse van ${ }^{5}$ ons gevoelen datelijck moeten laten verstercken ende fortyviceren. ${ }^{6}$

1 Natuurlijk schrijffout voor "heerlijckheden".

2 Battikaloa, aan de Oostkust, een der Portugeesche sterkten.

3 Het contract was opgesteld door de Nederlanders (Van Geer, bldz. 39).

4 Schrijffout voor: sterkte of sterkten.

5 Moet zijn: "naar".

${ }^{6}$ In den Portugeeschen tekst, door Westerwolt aan den Maharadja aangeboden, stond nog: „indient syn $\mathrm{May}^{\mathrm{t}}$ gelieffde ofte goet denkt, welcke 
4.

Zoo oock [zal] Zijne Maijt gehouden wesen, bij alldien eenige forten ende fortressen met onse officieren ende maght ${ }^{1}$ te besetten, maendelijcks haer soldije ende gagie te volldoen ende te betalen.

5.

Van gelijcken zall Zijne Maijt moeten toestaen, bij veroveringe van eenig sterckheden, geen gelegeuth ${ }^{t}$ offte bequame plaetse van huijsinge en waren, om onse goederen en coopmanschappen daerinne te connen bergen, dat alsdan Sijne Keijserlijcke Maijt naer tijt en gelegentheijt een steenen huijs naer ons goetduncken sall laten maeken op ${ }^{2}$ onse goederen voor brandt ende andere convenjentien ${ }^{3}$ ende swarigheden zouden werden gepraeserveerdt; als mede van gelijcken ende jnvoegen voorschreven een cruijthuijs om cruijdt, londt, ammunitie van oorloge ende andere scheepsgereetschappen daerinne te mogen brengen.

6.

Sijne Maijt, eenige saeken van oorloge tegens den Portugees willende attenteeren ofte eenige aenslagen bij der hand nemen, zall gehouden wesen eerst ende alvoore met eenige onser principaellste officieren der militarije te consullteren ende met raedt ende daet bij te staen, opdat alles tot wellstandt van Sijne Keijzerlijcke Maij ${ }^{\text {ts }}$ landen magh gedijen.

7.

Dat ook Zijne Keijzerlijcke Maijt zall versorgen ende diligenteeren, datter eenige fregats de remos ${ }^{4}$ metten alldereersten in zijn landt gemaeckt, van zijn volck tot roeijers naer behooren daer in

laetste clausule inde Nederlantse articulen by abuys ofte moetwillens uytgelaten was ...." (Dagh-Register 1640-1641, bldz. 335). Is hierbij werkelijk te denken aan opzettelijk bedrog, hoe dom dan ook (Vgl. Van Geer, Ceilon, bldz. 42)? G. G. \& Raden doen het voorkomen, alsof bij den "tolek ende translateur" Nicolaas Holsteyn de schuld lag en deze dan ook bevreesd was „van over voorschreven misverstandt ofte valsche interpretatie gecalangeert te sullen werden." G.G. \& R. gaven radja Singa dan ook gelijk, toen deze later tegen onze lezing opkwam (Vgl. Dagh-Register 1640-1641, bldz. 335, 410 , v.; Van Geer, Ceilon, bldz. 55, v.v.).

1 Contractboek Zeeland: "quamen te".

2 Contractboek Zeeland: "opdat".

${ }^{3}$ Idem: „inconvenienten".

4 Fragata de remos: roeifregat. 
geset ende van soldaten ende ammunitie van oorloge van ons gemant ende versien werden, omme Sijne Maijts stroomen, rheeden ende havenen met onse schepen, jachten ende diergelijck vaertuijgen te mogen bevrijden voor eenigh overlasst, invasie ende attentaet der Portugesen.

8.

Zijne Keijserlijcke Maije van Zeijlon met zijne Eedls ondersaten des rijex zullen aghtervolgen Zijne Keijzerlijcke Maijs ${ }^{\text {ts }}$ presentatie ende beloffte aen d'Ed. $\mathrm{H}^{r}$ Gouverneur Generael ende de $\mathrm{H}^{\mathrm{n}}$ raden van Jndien gedaen, gehouden wesende jaerlijkse oncossten alsmede de tegenwoordige equipagie ende uijtrustinghe der schepen, jaghten ende ande[re] cleijne vaertuijgen, als oock 't schenckvolck ${ }^{1}$, officieren ende soldaten, ammunitie van oorloge ende wat wijders daer aen is dependerende, die $\mathrm{d}^{ } \mathrm{H}^{\mathrm{n}}$ Bewindhebberen der Vereenighde Geoctroijeerde Oosstiudische Compe doort governo van d'Ede $\mathrm{H}^{\mathrm{r}}$ Gouvern $^{\mathrm{r}}$ Generael ende de raden van Indien over den Nederlantsen staet in Orienten ten dienste van Zijne Keijserlijcke Maijt landen van Zeijlon derwaerts zouden mogen stieren offt senden, d'oncosten daer op vallende, alles bij Zijne Maije sall moeten voldaen ende vergoet worden, soo aen caneell, peper, cardamom ${ }^{2}$, jndigo, was, rijs ende voorts alle andere cosstelijcke waren ende coopmanschappen, die jn Sijn Maij ${ }^{\text {ts }}$ rijck souden mogen vallen, uijtgesondert cauneell de matte ${ }^{3}$.

9.

Omme de vruntschap ende alliantie, die wij met Zijne Keijzerlijcke Maijt ${ }^{t}$ hebben aengegaen, accordeert, licentieerdt ende staet ons volcomentlijck toe, omme allomme in Sijne Keijserlijcke Maijts landen van Zeijlon een vrije handelinge ende commercie te mogen obtineeren ende met zijne onderdanen ende jngesetenen in alle steden, vlecken offte gehughten, rheeden, stromen, havenen ende rivieren met onse schepen, jaghten ende andere cleene vaertuijgen vredelijck ende ongemolesteerdt zullen mogen gaen ende keeren, handelen, coopen en vercoopen, ruijlen ende ontfangen, lossen, laden, versenden ende wijders met Sijne Keijserlijcke Maijt ende desselffs

\footnotetext{
1 Zeeland: "scheeps volk".

2 Een op Ceilon en elders (b.v. op de kust van Malabaar) inheemsche specerij (Vgl. Encyclopaedie, II, bldz. 195, sub voce Kardamoenggoe).

${ }^{3}$ Canella de mata $=$ boschkaneel? Vgl. Valentijn, V (Ceylon), bldz. 52.
} 
onderdanen traffiqueren ende handelen, gelijck als vrunden ende bontgenooten onder malcanderen gewoon zijn te doen, zonder gebonden te zijn in eenigherhande manieren aen Zijne Keijzerlijcke Maij ${ }^{\mathrm{offt}}$ zijne ondersaten, uiemandt uijtgesondert, eenige tollen, schattingen, chinesen ${ }^{1}$ offte andere ongellden wegens eenige coopmanschappen ende waren, hoe desellve soude mogen genaemt offt wat deckmantell gegeven worden, te betalen ende uijt te rijcken, maer alles liber ende vrij uijt Sijne Keijserlijcke Maij ${ }^{\text {ts }}$ landen sall moeten laten gaen ende passeeren, met verclaringe dat niemandt van Sijne Keijserlijcke Maij $^{\text {ts }}$ onderdanen, 't zij hooge offtte lage, wat staet, qualite offte conditie die soude mogen wesen, ende sullen vermogen aen ijmandt te verkoopen eenigh caneell, peper, was, oliphants tanden, als alleenlijck Zijne Keijzerlijcke Maijt. Belangende d'oliphanten beloofft ende verbint hem Zijne Maijt soo wanneer Zijne Maijt aen iemanden eenige oliphanten quame te vercoopen, t zij 4,10 offte 20 stucx, dat allsdan Sijne. gemellte Maijt aen ons daertegens sooveele zall vercoopen ende leveren.

\section{0.}

Zijne Keijzerlycke Maijt, koninck van Zeijlon ende Candien, met $d^{\prime} E d^{e n}$ en principalen zijnes rijex consenteren ende staen ons toe, dat van nu voortaen Sijne Keijserlijcke Maijt met zijn Eden en principalen niet ende sullen gedoogen offte int minste tollereren, maer integendeell aen eenen jgelijcken zijner ondersaten well expresselijck verbieden, datter geenige Europische als Engellsen, Francen, Deenen, Hooghduijtsche offte Orientaellsche natie, ${ }^{2}$ wie 't soude mogen wesen, niemandt uijtgesondert, eenige handelinge offte commercie van coopen, vercoopen, ruijlen offte verruijlen van eenige waeren offte coopmanschappen, in Zijne Maij ${ }^{\text {ts }}$ landen van Zeijlon vallende, meer sullen mogen ${ }^{3}$ offt drijven; veell min toelaten, eenige haerder schepen offt jaghten op de rheede van Zeijlon te laten comen, maer datelijck haer te gebieden van daer te vertrecken ende dat de voor-

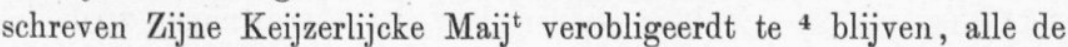
genoemde coopmanschappen ende waren, die in Keijzerlijcke Maij ${ }^{\text {ts }}$ landen souden mogen vallen, aen de Vereenighde Oosstjndische

1 Dwaze schrijffout voor "seijnsen" (Zeeland).

2 Van Geer, bldz. 39, is dus onjuist, waar hij spreekt alléén van de uitsluiting van Europeanen.

3 Zeeland: "doen".

"Zeeland: "zal" in plaats van "te". 
Comp ${ }^{\mathrm{e}}$ alleenelijcken, te verhandelen, vercoopen ende te leveren, met declaratie dat de naburige uijttet landt van Daneij ${ }^{1}$ van Tansjouwer vrij sall staen met haer vaertuijghen met eenige provisie, mantimentos ${ }^{2}$ ende andere cleijnigheden, sonder ijits anders, allhier te mogen comen ende ongemolesteerdt gaen ende keeren.

11.

Dat ook Sijne Maijt gehouden zall zijn, voor d'oncossten ende equipagie der schepen, die tot zijnen dienst in Zijne Keijserlijcke Maij $^{\text {ts }}$ landen gesonden en gebruijckt souden mogeu werden, ten minsten een a twee scheepsladingen van caneell, peper, cardamon, jndigo, was ende andere cosstelijcke coopmanschappen jaerlijcx naer $\mathrm{B}^{\mathrm{a}}{ }^{3}$ aff te senden; ende jngevalle de twee scheepsladingen meerder quamen te rendeeren als d'jaerlijcx oncossten vande equipagie der schepen souden comen te bedragen, dat allsoo Zijne Maijt t'vordere tot supplement van dien jn soodanige coopmanschappen, waren ende contanten, als Zijne Maijt soude mogen begeeren, sall werden voldaen.

12.

Zijne Maijt sall mede moeten toelaten, dat onse factooren ende cooplieden allomme in Zijne Keijserlijcke Maij ${ }^{\text {ts }}$ landen van Ceijlon vrij, vranck, ongemolesteerdt zullen mogen reijsen ende keeren, om haere negotie ende commercie mette jnwoonderen alldaer te drijven; daer eenige goederen binnen 'slandts opgecoght hebbende, sullen d'jnwoonderen gehouden wesen, eenige lasstdragende beessten daertoe op haer eijgen cossten te vergunnen, omme d'goederen ende coopmanschappen, die door onse cooplieden alldaer zouden mogen werden opgecoght, op strandt te laten brengen, t'zij in de logie offt aen de schepen, met verclaringe, dat onse Hollanders sullen staen onder onse eijgen jusstitie ende gehoorsaemheijdt, gelijck de ondersaten van 't landt van Zeijlon in vougen voorschreven onder Zijne Maijt subject sullen zijn.

13.

Dat ook alle persoonen, niemandt uijtgesondert, die met ons handelen, niet en zullen vermogen, eenige goederen, geene gereserveerdt, van 't geene wij met haer gecontracteerdt ende gehandelt

1 De Naik van Tanjore, aan de vaste kust ten W. en NW. van Ceilon.

2 Port.: mantimentos, levensmiddelen.

$s$ Batavia. 
hebben, aen eenige andere te leveren, voor ende alleer aen ons satisfactie ende contentement sullen hebben gedaen; ijemanden daer op bevindende datelijck te mogen aengeraeken ${ }^{1}$; van gelijcken, ijmanden aen ons een merckelijcke somme schuldigh wesende ende niet betalende, sullen mette selve mogen handelen als boven is aengeroerdt, met declaratie, offt gebeurde, eenige onderdanen van Sijne Keijserlijcke Maijt bij ons gevangen genomen moghten werden, dat wij luijden datelijck gehouden zullen zijn, zulx 't zij aen Zijne Maijt offt zijne gouvern ${ }^{\text {rs }}$ te adviseeren.

\section{4.}

Sall ook niemandt vermogen, t'zij wie ook zoude mogen wesen, van wat staet, cassto ${ }^{2}$, conditie offte qualiteijt hij zij, eenigh gelt te munten, maken offte uytgeven, minder off meerder dan van den Coninck ende Hollanders geset wordt, veel min valsch gelt te slaen; ende zoo ijmandt daer op bevonden werdt contrarie gedaen te hebben, 't zij Hollanders offte vassalen van Sijne Keijserlijcke Maij', jnwoonderen ende uijtlantsche persoonen, niemandt uijtgesondert, sall men sonder eenige genade arbitralijcken aen den lijve straffen, met conviscatie van alle hare goederen, die alleen sullen vervallen ten proffijte van Sijne Maijt.

15.

Ende offt gebeurde, dat eenige van onze Hollanders door gecommitteerde fauten, quat comportement offte ongeregelltheijt van leven, haer quamen in Zijne Maijt landen te vlughten, sall Zijne Maijt offte zijne ondersaten gehouden wesen, deselve wederom in onse handen te leveren; ende eenige van Sijne Maijts onderdanen, in voegen voorschreven bij ons comende te loopen, sullen jnsgelijcxken in handen van Zijne Maijt moeten geleverdt werden.

16.

Sall Zijne Keijserlijcke Maijt nogh zijne ondersaten, wie 't soude mogen wesen, niet vermogen, nae t' aengegane contract met ons, eenige heijmelijcke correspondentie, t' zij int secreet offte openbaer, met de Portugesen, onser ende zijner allgemeenen vijandt, te houden,

1 Zeeland: „aentasten ende sluyten, om alzoo door middel van dien aen onze goederen met haer gecontracteerd te mogen aengeraken."

2 Port. „casta". Hier in den meer algemeenen zin van: stand, positie (Vgl. Hobson-Jobson, p. 131, ff). 
veell min met $t$ sellve eenige concepten te maeken tot contracteren offte te handelen, t' zij met coopmansschappen, waren offte andersints, maer ter contrarie alltoos voor hare openbare vijanden te verclaren ende te houden; ende soo 't gebeurde eenige zijner ondersaten eenige waren, coopmanschappen offt wadt zoude mogen wesen aen de Portugesen vercoghten, aen den lijve ten exempell van andere sullen werden gestrafft ende gecorrigeerdt.

17.

Dat ook Zijne Maij ${ }^{t}$ genige papen, monicken offte andere geestelijcke persoonen, die allen oorsaeke van alle commotie, oneenigheijt, beroerte ende onderganck van alle coninckrijckeu ende landen, daer zij haer sellven begeven, sijn, int minste niet en sall gedoogen, Sijne Maijts landen te laten frequenteren, blijven offte haer domicilium te houden, maer haer opt allderspoedighste uijt te roeijen, allsoo zij luijden alltijts soeken, d'jnwoonderen tegens haer coningen op te hitsen, om soo door dien middell de landen met hullpe van de Portugesen te conquesteeren ende te vermeesteren.

18.

Zoo wanneer eenige onser schepen allhier ten dienste van Zijne Maijt quamen ende dat zij int gaen offt keeren, waer ter plaetse sulx soude mogen wesen, eenige prijsen quamen te veroveren, dat alle 't geene daerinne geladen zijnde ende gevonden werdende alleen sall comen in handen vervallen ${ }^{1}$ ten próffijte van de Holland ${ }^{\text {rs }}$ ende soo 't ook gebeurde, eenige onser schepen in t slaen offte andersints quamen te verliesen, dat de Hollanders alleen d'schade daervan sullen moeten dragen.

19.

Bij alldien wij luijden eenige stucken ${ }^{2}$ van onse schepen quamen te lighten, die op eenige forten offte fortressen geleijt ende ten dienste van Zijne Maijt gebruijckt souden mogen werden, dat wij luijden t' allen tijde ende des noodts vereijschende weder vrij ende liber naer ons sullen mogen nemen ende deselve aen onse schepen voeren ende brengen laten offte daer ons soude mogen geraden vinden.

Aldus gedaen, gearressteerdt ende beslooten ten overstaen van Sijne Keijserlijck Maij ${ }^{\mathrm{t}}$ van Zeijlon, den E. $\mathrm{H}^{\mathrm{r}}$ Adam Westerwollt, extra-

1 Zeeland: "alleen zal komen ende in handen vervallen."

2 Geschut. 
ordinaris raedt van Jndien ende commandeur over de presente navale maght, ende den Ed. vice commandeur Willem Jacobsszoon Collster ${ }^{1}$.

Int landt van Batacalo in 't tegenwoordigh paleijs van gemellte Zijne Maijt ${ }^{\mathrm{t}}$, desen $23^{\text {en }}$ Maij $\mathrm{A}^{\circ} 1638$.

Wordt naerder verclaerdt, dat alle de vaertuijgen, die van hier met paspoorden van Zijne Keijzerlijcke Maijt offte Sijn Maijts gouverneurs sullen vertrecken, de Hollanders gehouden zullen zijn, haer alle faveur, hulp ende assistentie te doen.

Actum als boven, dagh, maendt en jare als vooren ende zijn hier afgemaeckt twee alleensluijdende contracten van accoorde, uijt het Nederduijts in de Portugese spraake getranslateerdt ${ }^{2}$, die bij den emperadoor Radia Singa, keijser van Ceijlon en Candien, Adam Westerwollt ende Willem Cosster zijn onderteekent ende gecacheteerdt, soo mettet chachet van zijne voorschreven Maijt alls den voornoemden $\mathrm{H}^{\mathrm{r}}$ Adam Westerwollt.

\section{MOLUKKEN-AMBON.}

\section{Juni 1638. 3}

Zooals bekend is, heeft de gouverneur-generaal Van Diemen in 1638 een tweede reis gemaakt naar het Oosten van den Archipel. In Februari verscheen hij bij Ambon, waar in Mei ook kwam sultan Hamdja van Ternate en met hem werden thans onderhandelingen gevoerd, om de geschilpunten uit den weg te ruimen, vooral ook ten opzichte van de Ambonkwartieren met het oog op Ternate's gezag en invloed in die streken: geschilpunten, die blijken uit onderstaand zoo belangrijk contract, hetwelk gesloten werd na de beraadslagingen van 12-18 Juni 1638 (Vgl. o. a. Tiele-Heeres, Bouwstoffen, II, vooral bldz. LXII, v.).

Renovatie ende confirmatie van alle d' gemaeckte contracten ende verbintenissen tusschen den Coninck van Ternate jn Moluco ende zijne onderdanen in de landen van Amboijna ter eenre, ende de Nederlantsche Oosstindische $\mathrm{Comp}^{\mathrm{e}}$ ter andere zijden; mitsgaders een nieuwe

1 Schrijffout voor "Coster", zooals Zeeland dan ook heeft en ook het slot van ons exemplaar (Vgl. Van Geer, bldz. 37).

2 Vgl. hiervóór, bldz. 309.

${ }^{3}$ Uit het Contractboek. 
versekeringe op het precies naercomen der gemelte accoorden en volldoeningh van des Comp ${ }^{8}$ voorgestellde pretentien; gedaen ende affgehandellt bij Sijne Maijt Sultan Adia Amerill Monenin Hamsia Nasseron Min Alahicha, coninck van Ternaten, ende den gouverneur generael Anthonio van Diemen, geassisteerdt met de extraordinarij raden van Jndia Antony Caen ${ }^{1}$ ende Joan Ottens ${ }^{2}$, alle in persoon op Hittoe aen de reduijt, in vier generale gehouden vergaderingen, adij $12^{\mathrm{e}}, 14^{\mathrm{e}}, 15^{\mathrm{e}}$ ende $18^{\mathrm{e}} \mathrm{Junij}$ $\mathrm{A}^{\circ} 1638$.

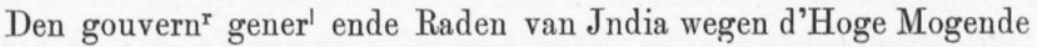
$\mathrm{H}^{\text {rn }}$ Staten Gener ${ }^{\mathrm{l}}$, Zijne Hoogh ${ }^{\mathrm{t}}$ ende vorstelijcke genade Frederick Hendrick, bij der gracie Godts prince van Orangien; grave van Nassau, etc ${ }^{a}$ ende d'Ede heeren Bewinthebberen van de Vereenighde Nederlandsche Geoctroijeerde Oosstindische Compe in Orienten, van tijd tot tijd met leedweesen vernomen ende gesien hebbende het verloop van saeken ende de geresene troubelen in dese Amboinse quartieren, principalijck met d'onderdanen des conincx van Ternaten ter saeke van haer gepleegde trouweloosheijt in 't vercoopen ende leveren hunner nagelen aan vreemde negotianten, die hier jaarlijx van Maccassar, Java ende andere landeren in groot getall well gewapent zijn verscheenen, mitsgaders bij desellve doorgaens tegen de Nederlanders beschermt en aengehouden, gants contrarie de solemnele besworen contracten en verbintenissen, successive met de Nederlandtse Compe aengegaen en gemaekt, soodanigh dat niet alleen gemelte Conincx onderdanen met assistentie der geseijde vreemdelingen all over eenige jaeren, om haren mijneedighen boosen wille ende vuijll gewin te doen, tegen de Nederlanders in oorloge hebben derven uijtbersten ende met veell bloetstortingh ter wederzijde tot noghtoe daerin gecontinueerdt, maer ook de Compagnies onderdanen door jnductie ende drijgementen soo verre gebraght, dat hun buijten gehoorsaemheijt begeven, de wapenen tegens deselve op genomen ende hun onder de quimelaha Leliatte, ${ }^{3}$ stadthouder wegen ge-

1 Deze in de geschiedenis van Ambon zoo bekend geworden ambtenaar der O. I. C. was met den G. G. in de Ambon-kwartieren gekomen.

2 Deze gouverneur van Ambon (1637-1641), een verzoeningsgezinde man, was opgevolgd aan Van Deutecom (vgl. hiervóór, bldz. 298) over wiens bestuur de Hooge Regeering niet tevreden was.

3 Over de kimelaha Leliatoe zie Tiele-Heeres, Bouwstoffen, II, passim, o. a. bldz. XLII, LVII, LXI, LXIII; hiervóór, bldz. 209. 
mellten Coninck van Ternaten in dese quartieren, te vervoegen gemeent hadden, js de saeke sulx met ernst bij der handt genomen, dat Zijne bovengemelte Edelheijt, den Gouverneur Generael, persoonlijck met een aensienelijcke maght van schepen ende volck 't gepasseerde wesster mousson $A^{\circ} 1637$ uijt Batavia herwaerdts vertrocken ende ter eerster aencomen stormender handt meester geworden zij van gemelte quimelahas sterckte ende vreemdelingen accesplaets op Luciella, ${ }^{1}$ brengende voort alle des Casteells onderdanen ${ }^{2}$ door ontsagh van wapenen ende minnelijcke aensprake tot haer vorige gehoorsaemheijt ende schuldigen plight. Eghter ten principalen voor die tijt aen de cusste Ceram, daer 't bleeff ressteeren ende ${ }^{3}$ wijder verrichtende, ten aensien vande verschijninge des Conincx affgesant Quitchill Siborij, ${ }^{4}$ capiteijn laoet, uit Ternaten, met commissie om nevens Zijne Edelheijt d'onlussten tot vreede te hellpen affhandelen; dogh niet alleen doen maer oock voor desen doorgaens ondervonden zijnde, dat gemelte gesanten gantsch weijnigh respect off ontsagh bij des Conincx onderdanen in dese quartieren hebben gehadt, wert bij den Gouverneur Generael en Raden van Jndie bovengemelt tot volcomen besleghtinge der geresen troublen ende verseekeringe, dat de Nederlanders in toecomende volgens d'oude ende vernieuwde beswooren contracten de nagelen alleen souden genieten, gantsch nodigh geaght ende dienstigh geoordeellt, Sijne Maijt van Ternateu bij den gouverneur generael meer genoemt persoonelijck in dese quartieren verscheen ende dierhallve geseijden coninck met brieven om herwaerdts te comen vrundelijck versoght, mitsgaders daerop in antwoorde ontfangen hebbende, tot sulx geresolveert ware, wanneer hem gerestitueerdt werde soodanige plaetsen als ten tijde der veroveringh van 't Cassteel in Amboijna bijden admr' Steven Verhagen $A^{\circ} 1605$ onder de Portugesen niet subject geweest ${ }^{5}$ en ${ }^{1}$ sedert de Nederlanders toegevallen zijn, heefft den Gouverneur Generael sigh op de belooffde conditien voor de tweedemaell met een aensienlijcke maght allhier zoo tijdelijck laten vinden, dat Sijn Maijt ontrent drie maenden is naegecomen. Eghter in der ijll heefft laten ontbieden alle desselffs

1 Luciela, aan de oostkust van Hoamohel, toen de residentie der Ternataansche stadhouders (Tiele-Heeres, Bouwstoffen, II, bldz. LVII, noot 1).

2 Onderdanen van het kasteel Vietoria, dus van de Compagnie.

${ }^{3}$ Bij Valentijn, I, b, bldz. 271, waar dit contract is afgedrukt: "niet wijders verrichtende", wat juist is.

4 Ofer kaïtjil Sibori zie Bouwstoffen, II, bldz. LXII.

${ }^{5}$ Een bekend twistpunt tusschen Ternate en de O. I. C. 
onderdanen in dese quartieren residerende, welcke als nu nevens Nederlandtsche Chrissten ${ }^{1}$ ende Moorse subjecten,${ }^{2}$ mitsgaders hunne bontgenooten, uijtgesondert den nutralen $\mathrm{Cap}^{\mathrm{n}}$ Hittoe, ${ }^{3}$ die sigh absenteerdt, alltsamen verscheenen ende te deser generale vergaderingh gecompareerdt wesende, soo zijn den Gouverneur Generael ende de Konincklijcke Maij ${ }^{t}$ van Ternaten meergemellt, met advijs haerder Raden, bevoorens aendaghtelijck gelet ende overleijdt hebbende, bij wadt middelen d'onlussten deser landen weghgenomen, de vreemde handelaers geweerdt, de Nederlanders van 't gem $^{t}{ }^{4}$ der contracten ende alleen compareerende de ${ }^{5}$ nagelen voortaen verseekert ende den coninck van Ternaten daerentusschen ${ }^{6}$ zijne toegeseijde pretentien ingewillight ende toegestaen moghte worden, jegenwoordigh ter wederzijde voor vasst, bondigh ende onverbreeckelijck overeengecomen, versproocken ende geaccordeert in maniere als volght, te weten.

Eerstelijck werden bij deseu vernieuwt, nogh voor chraghtigh geconfirmeerdt ende gecontinueerdt soodanige contracten, accoolden ende verbintenissen, als van tijt tot tijt tusschen gemelten coninck ende zijne onderdanen met de Nederlanders Comp ${ }^{e}$ in de Moluccos ende dese quartieren gemaeckt, mitsg ${ }^{\text {ds }}$ tegenwoordigh nogh well bewaerdt onder den Nederlandschen gouvern ${ }^{\mathrm{r}}$ in Amboijna berusstende zijn, voor zooveell in desen te contrarieren. ?

Ten tweede beloofft Zijne Maijt tot vollcomen russte der Amboineese landen verzekeringh, dat gemelte contracten sonder eenige inbreuke voortaen precis aghtervolght zullen werden, alls namentlijck:

Dat [hij] van hier met hem nae Molucco sall voeren alle de Tarnatanen, soo groodt als cleijn, met vrou, kinderen, slaven en ommeslagh, sonder daer eenige createuren van te laten off ook naemaells buijten des Gouvern ${ }^{\text {rs }}$ kennisse herwaerts te zenden.

Dat eenige ${ }^{8}$ vreemde negotianten, t zij Europische off Indiaense natie, niemandt uijtgesondert, in dese quartieren bij sijne overblijvende landtsonderdanen op hare stranden sullen werden geadmitteerdt, anders als die met goede passcedull van den Gouverneur-

\footnotetext{
1 Valentijn heeft: "de Nederlandsche Christenen."

2 Nl. van de Compagnie.

s Toen weder Kakiali. Zie contract CXXIII.

-Valentijn: "t genieten".

5 Valentijn: „en hun alleen competerende".

"Valentijn: „daarentegen".

7 Valentijn: „niet contrarieren".

8 Valentijn: „geen", wat natuurlijk juist is.
} 
Generael uijt Bat ${ }^{\mathrm{a}}$ versien comen, welcke dan nergens ellders sullen mogen anckeren als op de vier naervolgende plaetsen, te weten: voor 't cassteell Victoria in Amboijna, op Hittoe aen de reduijt, op Loehoe ${ }^{1}$ ende tot Combello, ${ }^{2}$ sonder meer, om haren handel te drijven, mits dat geen nagelen vervoeren. Item, allvooren [zij] vertrecken, door de Nederlanders ende de hooffden derselver plaetsen perfect gevisiteerdt ende dien aengaande bij onderteekeningh van de visitateurs op hunne pascedells verclaringh werde gedaen, geen giroffellnagelen, stelen nogh moernagells zijn jnhebbende, op pene van te verliesen lijff en goedt, ten proffijte van den Koninck ende de Nederlandsche Compe.

Dat mede jnsgelijex getracteerdt zullen werden die buijten vrijgeleijde van Zijne gem $^{\text {te }}$ Edelheijt den Gouverneur Generael in dese quartieren off op eenige ongeoorlooffde plaetsen verschijnen, dat de Nederlanders, soo tot weeringh der gemelte onvrije negotianten ende alle andere ${ }^{3}$ met hullpe van des Conincx onderdanen als om de nagelen te ontfangen, aller wegen ende ${ }^{4}$ acces plaetsen op des Conings landt soodanige forten, vasstigheden offte minder gebouwen sullen mogen maeken ende hare garnisoenen houden, als $t$ hem believen ende te rade werden zall, waerin des Conincx onderdanen ook verbonden blijven, haer te assisteren.

Dat des conincx jnlantsche ${ }^{5}$ subjecten, die hem tegen de voorschreven contracten off des conincx bevell eenighsints moghten comen te begrijpen, ${ }^{6}$ bij den Nederlantschen gouverneur in Amboijna, als principaell ${ }^{7}$ gesagh hebbende, ende den commies ${ }^{8}$ off stadthouwer, welck zijn Maijt voornemen is hier te laten offte zenden, naer bevindingh van saeken zullen werden gestrafft.

Dat ook des Conings onderdanen, soo Olisivas ${ }^{9}$, Olijlijmas ende de Nederlanders hare subjecten onder den anderen niet alleen gelijck vrunden maer ook broeders in eenigheijt leven ende van wederzijden gehouden sullen wesen den anderen in tijde van noodt met zoodanige

\footnotetext{
1 Aan de Oostkust van Hoeamohel.

2 Kambeloe aan de Westkust van Hoeamohel.

s Valentijn: nalle andere onderkruipers".

4 Aende?

5 Hiermede zullen bedoeld zijn de Ambonsche, in tegenstelling met de Ternataansche onderdanen.

"Valentijn: „vergrijpen".

7 Valentijn: "'t principaalste gezag".

8 Valentijn: "koning", wat natuurlijk foutief is.

9 Valentijn: „O. als O”.
} 
maght als elck bij brieven ${ }^{1}$ connen, prompelijck t' assisteren ende hellpen defendeeren.

Dat desellve conincx onderdanen buijten eenige voorvalligheden ${ }^{2}$ mede gehouden zullen wesen, met de Nederlanders nevens hare onderdauen eens jaers [te] pangaijen om de ronde te doen, eenige quatwillige zijnde te straffen off zodanige andere diensten als den Nederlandschen gouverneur ende Conincx commis tot des landts russte ende verseekeringhe sall hebben voor te dragen, mitsgd $\mathrm{d}^{\mathrm{rs}}$ ook op 't ontbieden van gemellten gouverneur eens jnt jaer bij den anderen te comen, namentlijck t' eene jaer aent Cassteell ende ' $t$ volgende op Loehoe off ter plaetse daer den voorgenoemden coninck stadthouder zijn residentie houdt, omme alldaer een ijder te hooren, de differenten bij te leggen ende elck naer vermogen reght te doen.

Ende ten derden, zoo accordeerde den Gouvern ${ }^{\mathrm{r}}$ Gener $^{\mathrm{l}}$ aen de koninck van Ternaten volgens zijn versoeck, onder dese expresse conditien dat de meergemeltte contracten aen de Nederlandtse Oomp ${ }^{e}$ voortaen gepressteerdt ende de nagelen ten prijse van $60 \mathrm{R}^{\mathrm{a}}$ courandt de baer van $550 \mathbb{H}$ Hollandts suijver ende droogh aen haer alleen vercoght ende geleverdt werden, off in contrarie desen null ende van geender weerden wesen zall, niet alleen soodanige volckeren ende plaetsen als $a^{\circ} 1605$, wanneer het Cassteell in Amboijna door den admr $^{1}$ Steven Verhagen van de Portugesen vermeessterdt wierdt, buijten subjectie dersellver Portugesen geweest ende 't sedert de Nederlanders bij gecomen sijn, maar ook all sullcke landen als nae die tijt met de Nederlandtsche Compe verbintenissen hebben gemaeckt, namentlijck Bourou, Manipe, Kelangh, Bonoa, Assahoudịj ${ }^{3}$, Lissebatta ${ }^{4}$, Lissidị . ${ }^{5}$ enz.; ende zijn de versogte plaetsen, die den Gener ${ }^{1}$ daer en boven, onder conditie als vooren, aen den Coninck inruijmt ende onder desselffs subjectie stellt, de volgende, te weten:

Ceram met alle de dorpen daer op geleegen, gene uijtgesondert; jtem op het eylandt Uliasser ${ }^{6}$ de Mooren van Jha en Manw met de cleijne negrijen die daer onder sorteeren, namentlijck Pisia, Nolot, Ourouw, Attala ende Matalette ?.

1 Valentijn: bijbrengen.

2 Valentijn: voorvallen.

3 Op de Westkust van Hoamohel.

4 Op de Noordkust van Ceram.

${ }^{5}$ Op de Westkust van Hoamohel.

- Bedoeld wordt Saparoea (Honimoa).

7 Valentijn heeft: „Piha, Nollot, Oehoe, Hatela en Watilette 7• Volgr. III. 
Ende op 't eijlandt Oma off Bovanghbessij ${ }^{1}$ de vier Moorse dorpen Hatuw, Cabouw, Queylola en Olisieuw ${ }^{2}$;

mits dat eghter begrepen ende gehouden blijven onder deselve poincten, die hier vooren gespecificeerdt, ende de Nederlandsche onderdanen even well gelijk voor desen op Cerams cusst sullen mogen sagouw maeken, mitsgaders haer gerieffelijckheden halen, sonder eenige tegenstandt off missnoegen.

Soo zall Zijne Maijt off desselffs stadthouder oock niet vermogen, d'affgestane onderdanen op do Cerams custe ende elders meer lassten off beswarenissen op te leggen, als bij de Nederlanders gesupporteerdt hebben.

Jnsgelijex confirmeerdt hem den Generael ook met d'uijtspraeke gedaen bij de vier hooffden van Hittoe, namentlijck Kaijouwan, orangkaij Teva en Tannahittoemessin ${ }^{3}$; Baros, nosetape; Bermeijll, patij Touban; ende de soon van den sieken Keylise, toetehatij, in absentie ${ }^{4}$ van Kakij Alij, Cap ${ }^{n}$ Hittoe, ende Telouckabessij van Capaha, gants contrarie hare voorleden jare gesamentlijcke verclaringhe ${ }^{5}$ aen Sijne gemelte Edelheijt, dat [zij] de Maijt van Ternaten als coninck ende gebieder over de 30 Hittoese negereijen erkennen ende aennemen; dogh sonder eenigh gesagh off pretentsie te hebben op deselve dorpen aen d'Zuijtzijde van dat landt geleegen, met. namen Orien, ${ }^{6}$ Asselloeloe, ${ }^{7}$ Laricque, ${ }^{7}$ Woceasiva, ${ }^{8}$ Olangh, ${ }^{9}$ Lissiboij ${ }^{9}$ ende Hatou, ${ }^{9}$ die ten tijde der verovering van 't Cassteell mede onder de Portugesen hebben gesorteerdt, sulx die als nogh zijn ende blijven onderdanen van de Nederlanders, hoewell hun 't zedert vier jaeren herwaerdts tegen deselve onder die van Hittoe geopposeerdt, daer over t' zijner tijt straffe te verwaghten hebben, des dat gemelte dertigh dorpen, nu subjecten des Conincx, mede verbonden blijven als vooren.

Zoo werdt ter wederzijden beloofft, dat des anderen onderdanen, 't zij Chrisstenen off Mooren, soo well in dese als de Molucce

\footnotetext{
1 Het eiland Haroekoe wordt ook genoemd Oma of Boewangbesi.

2 Valentijn: „Hatoeaha, Cabauw, Kailolo en Pelauw”.

3 Over deze en volgende personen en waardigheden zie hiervóór bij vroegere contracten, waar de schrijffouten des afschrijvers ook duidelijk blijken.

4 Vgl. Tiele-Heeres, Bouvstoffen, II, bldz. LXIV.

${ }^{5}$ Zie contract 1 Juni 1637 (no. CXXIII).

${ }^{6}$ Oering, aan de Noord-Westkust van Hitoe.

7 Asiloeloe en Larike, aan de Westkust.

8 Wakasihoe, aan de Zuid-Westkust.

9 Alang, Liliboi en Hatoe aan de Zuidkust.
} 
quartieren niet en zullen vermogen van haer aengenomen geloove te brengen, schoon daer selffs om moghten versoeken, nogh ook mallcanderen op die off andere wijse eenigh volck te ontrecken, maer elck bij de zijne laten, onder conditie als vooren verhaelldt.

Wijders accordeerdt den Generael Zijne Maijt, dat wanneer in de Moluccos eenige Tarnaten ${ }^{1}$ off andere sijne subjecten, vrije persoonen, ${ }^{2}$ allvooren bij den vijandt overgelopen wesende, gechrisstent offt Moors wedercomende, gelijck het contract mede brenght ende tot nogh toe is geschiet, deselve door de Nederlanders off Tarnatanen niet eerst aengesprooken, maar toegestaen sullen werden hun te vervoegen bij die datse willen: t' zij onder de Nederlanders tot het Christengelove off den Coninck bij het Moorsdom, sonder eenige persuagie; onder welcke conditie ook begrepen blijven alle Spangiaerden, Portugesen, Tijdooresen, Panpangers,${ }^{3}$ Chinesen, Japonders ende andere, die van de vijandt comen lopen.

Maer eenige slaven, jnsgelijcx overcomende, sullen weder bij haer meessters moeten gaen, off, Mardijckers wesende willende, sall de Comp $\mathrm{p}^{\mathrm{e}}$ daer voor aen den eijgenaer betalen de somme van $60 \mathrm{R}^{\mathrm{a}}$ van $8^{\text {ten }}$, halff in gelt ende de andere helfft aen kleeden. Voor gelijcke prijs off in nagelen zullen de Ternatanen ook vermogen van de Nederlanders te lossen soodanige Tijdoresen off hare slaven, als de Nederlanders van den vijandt in den oorlogh becomen.

Nogh beloofft den Koninck, $\mathrm{p}^{\mathrm{r}}+$ het ernstigh begeeren van Sijne Edelheijt den Gouverneur Generael, niet alleen promptelijck metter doot te straffen die van het eijlandt Soula, mede zijne onderdanen, welcke nu ruijm twee jaeren geleden seekeren Nederlandtschen coopman, Pieter Prauwellszoon ${ }^{5}$ genaemt, ende nogh twee solldaten, alldaer met een jonghen ${ }^{6}$ van Keij voorbij Banda gedreven comende, onder schijn van vrundtschap ende noodingh aen landt seer schandelijck vermoordt hebben, ${ }^{7}$ met den eersten te restitueeren, maer ${ }^{\circ}{ }^{\circ}{ }^{8}$ sodanige

1 Valentijn: „Ternataanen”.

2 Deze interpunctie cntbreekt. Ik heb de komma hier geplaatst; Valentijn plaatst ze achter "alvooren". Ik meen, dat het hier geldt personen, welke vóór het sluiten van het contract (alvooren) overgeloopen waren.

3 Van de Philippijnen.

"Valentiin: "op".

"Valentijn: "Pieter Paulusz". Zie hierover Tiele-Heeres, Bouwstoffen, II, bldz. 295, 317; Dagh-Register 1636, bldz. 237.

"Valentijn beter: ,jonkje".

7 Valentijn: „en ook".

8 Deze beide woorden moeten waarschijnlijk staan vóór "met den eersten". 
burgers slaven als daer successive uijt Banda verlopen gecomen zijn.

Soo authoriseerdt en recommandeert Zijne Maij ${ }^{t}$ mede bij desen dat ${ }^{1}$ Nederlandsen gouverneur van Amboijna, om zijn competerende gereghtigheden deser landen te vorderen ende die jaerlijcx met d'een off d'ander gelegentheijt, 't zij bij rescontre off op des Comps schepen, in Molucco toe te senden.

Ende om Zijne Maij ${ }^{t}$ het voldoen deser en voorschreven accoorden te meer te doen bejveren, soo werdt, volgens het advijs der Heeren Seventienen en de beloffte voor dato aen hem Koninck gedaen, bij desen door den Gouverneur Generael ende zijne Raedt tot een besluijt toegezeijt ende beloofft, dat hij ${ }^{2}$, zijne successeurs van de Compe, boven desselffs ordinarij gereghtigheijt, tot een vereeringh genieten sall de somme van vier duijsent $R^{a}$ van $8^{3}$ in comptant off sodanige rariteijten als begeerdt uijt $\mathrm{B}^{\mathrm{a}}$ off Amboijna jaerlijcx promptelijck betaelt sullen werden, wanneer de Nederlanders seekerheijdt hebben, dat alle de nagelen inde Molucce ende Amboinse quartieren, onder zijn gouverno vallende, 't zij bij groodt off cleijn gewasch, alleen in handen becomen, onder welcke expresse conditie voorschreven beloffte volldaen off in contrarie aghter gehouden sall werden ${ }^{4}$, daer op de Nederlandtse gouvern ${ }^{\mathrm{r}}$ in Ternaten off Amboijna, jtem des Conincx stadthouder, aendaghtelijck sullen hebben te letten, mitsgaders den Gener ${ }^{1}$ ende Zijne Maij ${ }^{t}$ dien aengaende jaerlijcx pertinent advijs moeten geven.

Alldus gedaen, geeijndight, besloten, geschreven, onderteijckent ende gesegellt int schip Fredrick Hendrick ter rheede voor Hittoe, desen $20^{\text {en }}$ Junij $\mathrm{A}^{0} \mathrm{XVI}^{\mathrm{c}} \mathrm{XXXVIII}{ }^{5}$.

1 Valentijn: „den".

2 Valentijn voegt hierin: „of".

3 Valentijn: "die hem in contanten" enz.

4 De vergulde keten, welke Ternate's koning aan de Compagnie thans bond.

${ }^{5}$ Bij Valentijn volgen nog de handteekeningen, waaronder die van de „koningen van Tidore, Gilolo" (Vgl. Bouwstoffen, II, bldz. LXV). 


\section{BENGALEN.}

\section{Juli 1638. ${ }^{1}$ (Stilo Romano).}

De ambtenaren der O. I. C. gingen voort met bij den Grootmogol de Hoegli'sche aangelegenheden voor te dragen en, wat het verkrijgen van fermans op het papier betreft, met succes, zooals ook weer blijkt uit de onderstaande documenten.

Translaet, uijt de Persiaensche tale int Nederduijts overgeset, van 't firman offte mandaet door Zijn Maijt Chijasijan aen de Vereenighde Nederlandtse Compe verleent, houdende op de nabab Assalamchan, groodt gouverneur wegens $d^{0}$ maijt van Groot Bengale etc ${ }^{a}$, luijdende als volght.

In den name Godts wie Een is.

Affcomstigh der allderheijlighsten geslaghte, ${ }^{2}$ wien ghij gelijck sijt in alle eerbaerheijdt, der suijversten suijvere, ondersteunsell, pijlaer van 't gantsche rijck, hoecksteen der allderconingen coningh, well seekere ende suijvere bewaerder van 's Coninghs schatten, waerdigh van den Coningh geeerdt en van harten gemint te zijn, door $\mathrm{U}$ amiable aengeboorene nature, die soodanigh is, dat niets in mijne gedaghten kome off $t$ kan door UE volvoerdt werden ende mijne lieffde als met een nette omvanght en t'uwaerds zijt treckende, wiens vermits ${ }^{3}$ ende wetenschap de werelt bekent zij, alle wellcke eere, lieffde en gunste, aff komstigh der allderheijlighste beschermers geslaghte, door godtvrughtigheijdt sigh waerdigh maeckt, wie ${ }^{4}$ Assalaamchan,

hebbende de hope der coningen coninghs gunste, sullt weten, dat nu tegenwoordigh door de Hollanders kunt gemaeckt is aen de alldersuijversten coningh, wiens glants de hellderheijt van de sonne te boven gaet, 't naervolgende, te weten:

hoe Asscaron ${ }^{5}$, gemaghtighde van Maijaer ${ }^{6}$, vyandtlijck en met

1 Uit het Contractboek.

${ }^{2}$ Vgl. hiervóór, bldz. 268 en noot 6 .

s Schrijffout voor "vernuft"?

4 Is?

5 Of Oscaron, een der "opperste pachters" van Hoegli (Dagh-Register 1637, bldz. 96 , v.).

" „Mirsia Maijoor", gouverneur (onder den stadhouder van Dakka) van Hoegli (Dagh-Register 1637, bldz. 96, v.). 
gewellt de waerde van $600, \mathrm{R}^{\mathrm{a}}$ in contant als waren dos (?) ontwelldight ende naer sigh genomen, daer en boven gemelltens nogh een geheell jaer ontschulldigh en buijten reeden in apprehentie gehouden heefft en naderhandt uijt de heghtenisse ontslagen zijnde, veel gewellts en oneere aengedaen ${ }^{1}$. Bij alldien van dese klaghten eenige sekerheijt in $\mathrm{U}$ gemoet sijt bevindende, soo mandere ick aen den pijlaer van dat rijcke, dat bij wegen voorengemelte klaghten verdaght zij ende 't geene dat voornoemde Asscaron t' onreght buijten reeden met force de Hollanders soude mogen affgenomen hebben, de seekerheijdt vernomen hebbende, sullt hem desellve vorderen ende geven aen de geene die se gereghtigh toecomt en traght dat soodanige klaghten van overlasst ons naer desen niet meer ter ooren coomen ende beveelen wij $U$ andermaele serieusselijcken te letten, diergelijcke ongeneughten, welcke ons in geen deele gevallen, maer in contrarie seer dissgussteren, naer deesen niet meer voorcomen, waerdoor onse lieffde en affectie dagelijcks meer ende meer tuwąerdts accesseeren en toeneemen zall.

Gegeven den $20^{\mathrm{e}}$ van de maendt Seer Soffer chodt mullchier wollsoffer ${ }^{2}$, in 't $11^{\mathrm{e}}$ jaer onser regeeringe, $\mathrm{A}^{\circ}$ Mahomet 1048 Hiserij ${ }^{3}$, sijnde in 't jaer onses Heeren ende Salighmakers Jesu Chrisstij 1638 den $17^{\mathrm{e}}$ dagh van de maendt Julio, stilo Romano. Boven aen int midden stondt segell van Sijne Maijt Chyassgaen int ronde met swarten jnt gedruckt; onder aen d' eene hoek stondt t' zegell van Sijne Maijts outste soone, gem ${ }^{t}$ Para Secko ${ }^{4}$, met swarten jnt gedruckt, en weijnigh ter zijden in letters met zijn eijgen handt geschreven: Jck, devoote, godtvrughtige en zoone van grooter lieffde, Dara Secko. Wat lager van des Conings cancelier, genaemt Affehellehan, met sijn eijgen handt geschreven stondt: dit is verkreegen uijt handen van den alldergeringhsten onder de grootten, wie is Affellchan.

1 Dezelfde vexaties als waarvan de ferman van 18 September 1636 (hiervóór no CXVII) spreekt.

2 Safar 1048 begint 14 Juni 1638.

3 Hidjrah.

4 Dara Secko. De oudere broeder dus van Aurengzib. Ygl. hiervóór, bldz. 269 , noot 6 . 
Translaedt, uijt de Persiaense tale int Nederlants overgeset, van 't firman offte mandaet door d' Coningh, den grooten Mogoll genaemt Chija-Sijan, aen de Nederlanders verleent, om den vrijen onbecommerden handell in Ouglij en door geheell Bengala te mogen genieten met hare schepen en jaghten op alle plaetsen, poorten ende zeehavens te mogen gaen ende keeren, sonder eenige verhinderinge aengedaen te worden, mits betalende sodanige thollen, als aghter op den dosse en hier voor gejnsereedt te beoogen is ${ }^{1}$, welchers jnhoudt is ende luijt als volght:

In den name Godts, wie een is.

Alle gouverneurs, presente en toecomende, in de provintie van Bengale, hebbende de hoove van de Koninck verthoont hebben ${ }^{2}$, hoe voor desen een forman van den Koningh hebben gekregen ${ }^{3}$, hoedanigh forman een forman van grooter extime ende waerdigheijdt, houdende op alle gouvern ${ }^{\mathrm{rs}}$ ende regeerders in de provincia van Bengalen, 't welcke haer vergunt was, dat de Compe Nederlandtsche coopluijden in Ouglij en alle Bengaellse plaetsen haren handell vrij en onbecommert souden vermogen te drijven met hare schepen en jaghten naer contentemendt, sonder eenigh beletsell mogen gaen ende keeren, laden ende lossen, naer 't haer gelegen quam, jn welcke maniere zijlieden met haere schepen als andere coopluijden deden, gecomen zijn, om de Coninghs jncomen te vermeerderen en d'plaetsen in negotie te accresseren, dogh heeft Asscaron, gemaghtichde van Maijaer ${ }^{4}$, door insunuatie van de Portugesen $d^{\circ}$ firman van groote valeur en waerde met een groot force haer ontwelldight ${ }^{5}$; oversulcx mandeert den Coningh, allsoo continuell tot heden toe van de Hollandtse Comp ${ }^{e}$ wortell d'vrughten genooten hebbe, van wie tot. nogh den Coningh niets voorgecomen is, waeraen eenige missnou-

1 Zie hierachter, bldz. 330.

2 Hier is natuurlijk iets uitgevallen, waarin over de Nederlanders wordt gesproken.

3 Zie hiervóór.

${ }^{4}$ Vgl. hiervóór, bldz. 325.

5 Dagh-Register, 1637, bldz. 97. 
ginge genoomen heefft, ende door 't comen ende gaen van gemellte Compe schepen als de negotie de plaetsen toeneemen en 's Konings incomen vermeerderen zall, dat haer lieden op wadt plaats voornemens en geneegen zijn te comen, om haren handell te drijven, geen verhinderinge, veell min eenigen overlasst aengedaen werde, maer deselve vrij en liber in alle plaetsen laten genieten, daar 't haer gelegen comt, en naer haer contentement koopen ende verkoopen lijwaten, zijde, jndigo, was, suijker, rijs ende sallpeter, daerinne ghij haer voornemen niet sullt jmpedieeren, 't welcke naercomende sullen zij luijden met genegentheijdt en vergenouginge in alle plaetsen offte havenen haren handell naer haer wellgevallen connen vervollgen; derhallven belet haer gaen noghte comen niet in eenige plaetsen, poorten offe zeehavenen, daer genegen zijn te traffiqueeren noghte mede gedooght niet, haer van ijmandt eenigen overlasst in hare huijsen, aen hare middelen aengedaen werde, mits zij luijden betalen soodanige thollen ende geregtigheden, als met de Compe vrije wille van outs toegestaen en geaccordeert is van uijtvoeren alls inbrengen, soo well van juweelen, comptanten ende coopmanschappen, als op den dosso van dit conings firman ampell gespecificeerdt staet. ${ }^{1}$. En d'geene die do voornoemde firman van grooter waerde met gewellt haer ontwelldight hebben, soodanigh te corrigeeren en dat strecke tot schrick en exempell van soodanige, die jn toecomende onwaerdelijck onse mandaet offte firman souden onderstaen te vernietigen, alle welcke bovenstaende faveuren haer sullt laten genieten, soo lange $\mathrm{s}$ Conings mandament niet contrarieeren en ènige sijner onderdanen beschadigen offte d'Moorse navigeerende scheepjens op eenige plaetsen, soo verre sijne Maijt rijck uijtspreijt, verhinderinge offte belettselen wegens haer negotie aen doen ${ }^{2}$. Eijndelijck sullt haer alle faveur en vriendtschap laten genieten ende onse mandaet hier boven gementioneerdt in alles naerkomen.

Gegeven den $21^{\mathrm{e}}$ van de maendt Seersoffer chattmullcheir woll zoffer, int $11^{\mathrm{e}}$ jaer onser regeeringe, $\mathrm{A}^{\circ}$ Mahomet 1048 Hiserij $^{3}$, zijnde jnt jaer onses Heeren ende Salighmaker Jesu Christi 1638 den $18^{\mathrm{e}}$ Julij. Boven aen in 't midden stondt 't zegell van Sijne Maijt Chijan in 't ronde met swarten jnt gedruckt en onder op den dosso aen d'eene houck t' zeegell van Sijne Maijts outste soone

\footnotetext{
1 Vermoedelijk het hierachter volgende document.

2 Een der uitingen van 's Compagnies optreden in die streken.

3 Vgl. hiervoor, bldz. 326 noot 2.
} 
Daro Secko als vooren met swarten inct, en weijnigh ter zijden met desselffs eigen handt geschreven: Jck devoote, godtvrughtige ende soone grooter lieffde: geteijckent Daro Secko. Nogh lager van des Koninckx cancelier met zijn eijgen handt geschreven: dit is verkregen uijt handen van den alldergeringsten onder de grooten, wie is Affsellcham.

Translaedt van de tollen ende wadt de Nederlanders in alle de Bengaellse quartieren, principaell in Pipịjlịj ${ }^{1}$, van alle coopmanschappen ende waren, zoo well voor .uijtgaen als jncomen, gehouden sullen zijn te betalen.

Aen een zijde stondt in letters geschreven: dit ondergeschreven is waer.

Jck gebiede, dat ghij sullt, naer voor desen in gebruijck gewesene thollen en cosstumen, van de gaende ende keerende scheepen haren ingeladene goederen, die aenbrengen offte van daer moghten voeren, haer sullen doen betalen ende affnemen, sonder daer in te vermeerderen noghte verminderen.

${ }_{1}$ Deze uitdrukkelijke vermelding van Pippli, welke plaats niet wordt genoemd in den bovenstaanden ferman, heeft mij eerst doen twijfelen, of dit tarief van in- en uitvoerrechten wel behoort bij den ferman. Maar ik ben van dezen twijfel teruggekomen.

Over onze vestiging in Pippli vergelijk hiervóór, bldz. 286. G. \& R. schreven daaromtrent nog: "Ons kruisen in de bocht van Bengale heeft de uitwerking gehad dat ons in Pippli de vrije handel is toegestaan." Vgl. ook het rapport van Mahuysen aan de Staten-Generaal van 5 September 1641 in de Bijdragen Hist. Gen., III, o. a. bldz. 349. 
Ter zijden stondt: Soodanigh sullt ghij handelen, wanneer de Nederlanders met hare schepen in eenige zeehavens comen, te weten:

Niet meer als 20 offte ten uijtersten 30 Nederlanders aen landt sullen mogen comen ende dat zonder eenigh geweer noghte mede genigh mes bij haer te mogen hebben ende wanneer de voornoemde 20 à 30 weder aen boordt zijn gegaen, in desselvens plaetse andere gelijcke getall aen landt sullen mogen comen, tot bevorderinge van hare negotie, lossen en laden haerder schepen ende coopmanschappen.

\section{Lager stondt:}

Dit volgens is de cosstume, die den gewesen gouverneur van Suratta, genaemt Miermosa ${ }^{1}$, schrifftelijcken, allsmede de canagouw ende drouw ${ }^{2}$ van $d^{0}$ Suratta onder haer signature, aen den Coningh hebben overgegeven, concernerende de thollen, die de Nederlanders, Engellsen, Mooren en alle coopluijden in Suratta jaerlijcks van hare uijtgaende en incomende goederen betalen; en zijn als volght.

Eerstelijcken: gellt, gemunt offte ongemundt, goudt offte silver, daervan betalen alle coopluijden, te weten Benjanen, Hollanders, Portugesen, Mallabaren, Armeniers, Engellsen etc ${ }^{\mathrm{a}}$, $2 \frac{1}{2}$ percento.

Van allderhande lijwaten en cleeden, hoedanigh die souden mogen zijn, mitsgaders laken stoffen en zijdewaren 2 per $\mathrm{c}^{\text {to }}$ voor uijtgaen ende incomen naer basaers prijs.

Van allderhande maintementos offte granen, tarwe, garst, rijs, erweten, bonen, boter, olije etc ${ }^{\mathrm{a}}$, voor jncomen 2 en voor uijtgaen $3 \frac{3}{4} \mathrm{p}^{\mathrm{r}} \mathrm{c}^{t_{0}}$; van soudt voor jncomen en uijtvoeren $4 \mathrm{p}^{\mathrm{r}}$ cento.

Van betell voor uijtgaen ende incomen van 200 bladen 2 peijs.

Van jndigo bijana in Agra geteellt, voor uijtgaan en jncomen 4. $\mathrm{r}^{\mathrm{a}} \mathrm{p}^{\mathrm{r}}$ pack van 4 man, a $53 \mathbb{H}$ Nederlandts $\mathrm{p}^{\mathrm{r}}$ de man, volgens den Agraschen packagie; van jndigo sirchees voor uitgaen en jncomen $3 \mathrm{r}^{\mathrm{a}} \mathrm{p}^{\mathrm{r}}$ pack, volgens d'Ammodabatse packagie, a $36 \frac{1}{4} \mathbb{6}$ Nederlandts de man.

Van paerden, oliphanten, cameelen, muijllesels, boken etca. voor uijt te voeren ende in te brengen $2 \frac{1}{2} \mathrm{p}^{\mathrm{r}} \mathrm{c}^{\mathrm{t}_{0}}$.

Van slaven, soo Turcken als Arabiers, $12 \mathrm{p}^{\mathrm{r}} \mathrm{c}^{\mathrm{t}_{0}}$ voor jncomen.

Van Habbassijs offte Caffres ${ }^{3} 7 \mathrm{p}^{\mathrm{r}} \mathrm{c}^{\text {to }}$ voor jncomen.

1 Vgl. hiervóór, bldz. 269.

2 ?

3 Natuurlijk niet op te vatten in den tegenwoordig gangbaren zin. Misschien de Kafirs van Kafiristan in het N.O. van Afghanistan en het uiterste Noorden van het tegenwoordige Britsch-Indië. Een deel der bewoners heet nog Kafir. 
Van provisie tot de voijagie als plunderagie tot kleedinge van 't scheepsvolck ende diergelijcke, daerinne sall men discretelijck handelen, 't zij dat men wadt neeme offte niet.

Van mackelaerdije ${ }^{1}$ voor dese naervolgende coopmanschappen, als namentlijcken roodt koraell, peerlen, armringen van oliphantstanden, barnsteen en diergelijcke coopmanschappen, dewelcke meesst gekoght werden door de Jogies ${ }^{2}$, Mooren offte ijmandt die daerin will handelen, sullen betalen 1 per $\mathrm{c}^{\text {to }_{0}}$ ende andere chiapers ${ }^{3} 8$ peijsen per $c^{t}$, waer van andere coopmanschappen geexcuseerdt ende niet gehouden zijn daer eenige makelaerdije voor te betalen vollgens jnhoudt des firmans.

Van d'(?) off heell groff lijwaedt voor 't stuck van omtrent 16 ges 15 sietell à 25 sietell $\mathrm{p}^{\mathrm{r}}$ peijs.

Van do van Cambaija, langh omtrent 15 à 16 Suratse ges, à 10 sietel $\mathrm{p}^{\mathrm{r}}$ paijs.

Van alle specerijen, te weten nagelen, foelie, campher, quicksilver, bengewijn, spiouter, geell coper, hartall ${ }^{4}$, solpher, olie, mirre, barnsteen, ackerkera ${ }^{4}$, packenbeedt ${ }^{4}$, betsinaeck ${ }^{4}$, asivan ${ }^{4}$, roosoot ${ }^{4}$, cathooll ${ }^{4}$, rottecruijt, rampetter ${ }^{4}$, ruijnas, nacka offte deckseltjents van slackhuijsiens, komen veell van Atchin, à 8 peijsen ende diergelijcke drooguen.

Van harle ${ }^{4}$, honigh, beeghbenossa ${ }^{4}$, sallpeter, bramma ${ }^{4}$, gallnooten, lack, tserijta ${ }^{4}$, canafustula, atteeus ${ }^{4}$, lange peper, serongie ${ }^{4}$, cambijla ${ }^{4}$, ro aerde, peper, was, maghsiera ${ }^{4}$, matsieres ${ }^{4}$, bringie ${ }^{4}$, daervooren wert geen tholl uijtgetrokken.

Van pijnangh, cocusnoten, drooge dadells, catseur, ${ }^{4}$ hingh, curcuma, ${ }^{5}$ corijander, commijn, maallkanginij, ${ }^{4}$ wortell van amandellboomen, soamendij, ${ }^{4}$ tomallper ${ }^{4}$, timmerhoudt, genaemdt deuwdaer, gougell ${ }^{4}$, anijs, halm katta ${ }^{4}$ offte catchia, allderhande groente, warmoes, gengber, bananassen ende diergelijcke etc ${ }^{\mathrm{a}}$, voor een karstlasst $^{6}$ van 4 ossen 16 peijsen, van 2 ossen 10 peijsen ende een lighte sitkar geladen zijnde met gemelte drooguen als grounte 4 peijsen.

1 Makelarij, makelaarsloon.

2 De Jôgin of Yogis, de bekende Sjiwaietische secte?

3 Misschien moet hier gelezen worden: "ende aende siappers" (Vgl. hiervóór, bldz. 288). — „1 Ges is $1 \frac{1}{6}$ el" (Vgl. Dagh-Register 1643-1644, blz. 200).

4 ?

${ }^{5}$ Kurkuma-wortel. Vgl. Encyclopaedie, II, bldz. 255, n.l. voce „Koenjit."

${ }^{6}$ Kar's last? 
Voor een ossenlasst offte pottij $1 \frac{1}{4}$ peijs offte 30 sietell, van booter ende vettewerije 2 peijs per man; van een buffells huijt 15 sietell.

Van een corgie offte 20 stx bockevellen 2 peijs.

Van een ossen offte koehuijt 7 sietel.

Een lasst kar met houtwerck en bamboesen 10 sietell.

Ter zijden van dese voorenstaende gespecificeerde thollen heefft den cancelier van den Koninck, Asschelcan, laten schrijven dit vollgende, daer d'E. Comp niet veell goedts door kan geschieden ${ }^{1}$ :

Waer en seecker ist, dat aen Ul., alle gouverneurs ende bevellhebbers van Ooresa ${ }^{2}$ schrijve, dat gij lieden sullt vernemen nae de seeckerheijdt van alle thollen ende gereghtigheijdt, die lange jaeren voor desen tot heden toe in alle plaetsen, onder ' $t$ gebiedt van $d^{\circ}$ Oreesa sorteerende, betaelt zijn geworden ende desellve met die van Suratta, dewelcke wij nu aghter dit Coningh's firman gestellt hebben, confronteeren, dewelcke oversien hebbende, sullt ghijlieden de profitabellste voor s' Conincks incomen, t' zij die van Suratta off well d'voor desene costume alldaer van deselve vorderen.

\section{KUST VAN KOROMANDEL.}

\section{November-December $1639 .{ }^{3}$}

Onze handel in het rijk van Golkonda nam steeds toe, vooral in de kleeden. In onuitgegeven berichten uit Indië van 1639 worden als belangrijke handelsplaatsen vooral genoemd Palicol, Dacheron en Petapouli (Vgl. hiervóór, bldz. 242, 232). ${ }^{4}$ ) Onderstaande fermans zijn vooral hierom

1 Iets dergelijks geschiedde met den ferman van November 1636 (Zie DaghRegister 1637, bldz. 246).

${ }^{2}$ Het landschap Orissa behoorde in deze dagen niet tot het nabab-schap van Bengalen (Dakka). Over dit landschap Orissa was gesteld een afzonderlijke nabab (stadhouder), onder wien stonden "gouverneurs", o. a. van Pippli (Vgl. hiervóór, bldz. 286; Dagh-Register, 1640-1641, bldz. 216). In 1578 was Orissa aan het rijk van den Grootmogol getrokken (Hunter, Gazetteer, VII, p. 199).

$s$ Uit het Contractboek Zeeland.

De inhoud komt overeen met den ferman, afgedrukt bij Havart, Cormandel, II, bldz. 105 v.v. Misschien is hij eene andere lezing van hetzelfde document. In elk geval neem ik Havarts stuk hier niet over.

4 Vgl. hiervóór, bldz. 46. Zie ook bldz. 154, 234. 
van belang, dat zij opnieuw en thans zeer uitdrukkelijk geheel Golkonda voor den handel der Compagnie openstellen onder de in de stukken vervatte voorwaarden; voor een groot deel natuurlijk slechts een sanctie van wat reeds feitelijk plaats vond.

Firman van de Golcondase koning sulthan Abdulla Cotobsjah a $a^{0} 1639$ aan 's E. Compagnie's hoofd in Mesulipatnam verleend.

Alle gouvernements etc ${ }^{a}$ sullen verdagt sijn, dat de Hollanders op haar verzoek toegestaan hebben en vereerd,

dat alle hunne goederen en coopmanschappen met haar scheepen aankomende, alsmeede de kleeden die se in mijn land souden mogen negotieren (gelijk van ouds gebruijckelijck), sullen mogen op- ende afvoeren, verkopen en de koopen waar ende werwaarts het hun goed dunken ende believen sal, sonder dat iemand onder mijn geheele gebied daerop iets sal hebben te pretendeeren.

Alle Moorsche, Benjaensche, Jentiefse ende ander coopluijden sonder uijtsondering van iemand sullen haare goederen vrij en onbekommert aan de Hollanders mogen verkopen, ende wederom van deselve in plaats negotieren al 't geene begeeren en hun aanstaen sal, sonder hun daarin hinderlijk te weesen, maar de huijsinge der Hollanders ende haer negotie vrijelijck ende onverhinderd te laten frequenteeren.

Het goud ende zilver met haar scheepen in mijn rijk aanbrengende, sullen aan den meestbiedende ende wien hun goed denken sal, mogen venten, sonder daar van eenige jonkan ofte geregtigheid te betalen.

Ende sullen geene gouverneurs in ende ter wat plaatse het in mijn rijk ook soude mogen wesen, vermogen de Hollanders in haaren handel eenig belet te doen maar ter contrarie gehouden zijn haar behulpzaam te weesen ${ }^{1}$.

1 In het Contractboek Zeeland worden nog vermeld in extract de volgende bevelschriften enz. van Golkonda's vorst:

10. "Vier bevelschriften van den Golcondaschen koning op de regenten van Mustafanager (Condepillij), Mortusanagor (Condawdoe), Deschengael (een district van Eloer) en Daatcherom, annex aan Muhamed - Sja Nagoer (Rasimandrie) verleend, waar bij strict verboden werd eenige wegs en booijs (vragtbeesten, ossen) ongelden te vorderen, gegeven den $4^{\text {en }}$ van de maand Sikada $a^{\circ} 1047$ of $a^{\circ} 1636$ den ...." (De ligging dier plaatsen is hiervóór, bldz. 234, aangegeven. - Dzoe'l-Kadah 1047 begint 17 Maart 1638, niet 1636).

$2^{\circ}$. „Bij forman van den Golcondasen koning Abdulla Cotobsjah A ${ }^{\circ} 1639$ verleend.

Waar bij vergund werd den handel en het vervoer der coopmanschappen 
Waar teegen de Hollanders jaarlijx eens (volgens oude costumen) tot een recognitie sullen betaalen 3000 Masulipatnamsche pagooden sonder meer.

Gelastende alle mijne gouverneurs etc ${ }^{\mathrm{a}}$ etc $^{\mathrm{a}}$, waarmeede de Hollanders haar sullen gerust ende verseekerd houden, sonder eenig verder nadenken, mogende scheepen ende coopmanschappen naar welgevallen aanbrengen, ende weder afzenden, mitsgaders ook hunne negotie selvs, ende door andere dienaars onverhinderd ende in der minne exerceeren souder iemands teegen zegen etc ${ }^{\mathrm{a}}$. etc $\mathrm{c}^{\mathrm{a}}$.

Gegeeven in de maand Thiaban in 't jaar van Mohamets geboorte $^{1} 1049$.

Daar is een bevel-schrift ${ }^{2}$ over de wereld te gehoorzamen, en verheven als de Zon, voor het hoog aanzienlijk Hof, overvloedig in heerschappije, op de Regenten, Officiers, en bedienaars van de quartieren omtrent de woning van veyligheid, de stad Heyderabaad ${ }^{3}$, en den oord van Wildenda, tot aan de volck-rijke zeeplaats van Mazulipatam toe, in dezer voegen met een luyster uytgegaan, namelijk dit.

Alzo het puyk onder zijns gelijken, den Capiteyn van de Hollandsche Natie, volgens het beleyd van een verre-ziend oordeel zich

in de quartieren tusschen Masulipatnam en Golconda, met ordre aan de regenten daar toe de behulpsame hand te bieden." (Dit is blijkbaar de ferman, door mij uit Havart, Cormandel, beneden overgenomen).

$3^{\circ}$. „Forman door den selven verleend in December 1639 wegens de vrijen handel in Siccacol en langs de cust van Singelij, daar bij de regenten ordonneerende, d'E. Compagnie hare schulden des noods te moeten helpen invorderen." (Deze ferman trof ik niet in zijn geheel aan. - Siccacol is waarschijnlijk Chicacole aan de Nagavali-rivier op c.a. $18^{\circ} 15^{\prime}$ N.B. en $84^{\circ}$ O.L., dat toen tot Golkonda behoorde. Vgl. Hunter, Gazetteer, II, p. 429 en de kaart van Choromandel bij Baldaeus. - Singelij kan ik niet terecht brengen. Reeds minstens sedert 1628 handelde de O. I. C. op Vizagapatam, ten Z.W. van Chicacole).

1 Sic! - De maand Sjaban 1049 loopt van 27 Nov. tot 25 December 1639.

2 Overgenomen uit Havart, Cormandel, I, bldz. 149.

s Vgl. hiervóór, bldz. 235, noot 7 . 
in de schaduwe, en beschutting van het dagelijks vermeerderende Hof begeven hebbende, in de zee-koop-plaatze Mazulipatam is komen woonen, zo hebben wy uyt een Koninklijke gonste, en beleeftheyd hare verzouken en begeerten, met de eer van inwilliging te zaam gevoegd, en bij dit bevelschrift geboden.

Dat zij Hollanderen in de boven-genoemde quartieren allerley zoort van koopmanschap, en goederen mogen kopen, en verkopen, en naar, of in die zee-koop-plaats naar andere plaatzen, om te verkopen, vervoeren, hebbende zij [Regenten] haar hier in de behulpzame hand te betonen, zonder haar ter oorzake van Pullery ${ }^{1}$, weegs en plaats geregtigheyd Moelawizaal ${ }^{2}$, en zommige andere afvorderingen, moeylijk te vallen, zich daar tegen te stellen, of yet te eyschen, en te vorderen, noch in geene manieren yets te begeeren, of te verwagten, aangezien alle hare goederen, en koopmanschappen, zo wel die zy kopen, als verkopen, aan haar [Hollanders] vry verklaard zyn, dierhalve moeten zy [Regenten] zich naar luyd van dit werelds onderdanige bevel-schrift gedragen, en zich in het zondigen daar tegens wagten, en houden dit van een hoognodige zaak van een sterken aandrang. Geschreven in de grote eerwaardige mane Sjabaan, Anno Muhammeds 1049. Anno Christi 1639.

\section{AMBON.}

16 Mei 1640. ${ }^{3}$

Het is bekend, dat ook na Van Diemen's tweeden tocht (vgl. hiervóór, bldz. 316) de rust in de Ambonsche kwartieren niet was hersteld. Kakiali en de stadhouder van Ternate's sultan, de kimelaha Loehoe, bleven een vijandelijke houding voeren èn tegen de O. I. C. èn thans ook tegen Hamdja, voorzooverre deze beschouwd werd als met de onzen te zijn verbonden. In die strubbelingen vond ook een tocht plaats naar Bonoa, waar een deel der bevolking de zijde onzer vijanden had gekozen, maar in Mei 1640 door de onzen werd onderworpen en bevredigd (Vgl. Bouwstoffen, II, bldz. LXIV, v.v.; Dagh-Register 1640-1641, bldz. 46, v., $290,454)$.

In den jare onzes Heeren Jezus Christus op den 16 dag der maand Majus A. 1640.

${ }^{1}$ "Pullery is een geschrift wegens de geregtigheyd, die aan den Heer voor het weyden van draag-beesten betaald word."

${ }^{2}$ "Malla-Wizaal beteykend een geregtigheyd van yder osse-dragt goed een Wiza, 't welk omtrent drie duyten naar onze rekening beloopt."

3 Overgenomen uit Valentijn, II, (Ambon), b, bldz. 128. 
Wy, Pieter de Goyer, Koopman, en Jan Oetgenszoon, Capitein in den name van de Heer Gouverneur, Jan Ottens, ende alle Orang Kaja's, Oelisiwa's en Oelilima's, van 't land Ambon, met den Sengadji Lessidi ende den Orang Kaja Sengadji Bonoa, Orang Kaja Hatib Lanoero, Tama-ela Meti, en Tama-ela Mariket, hebben dit getekend, ende met eede bevestigdt 't naarvolgende.

Eerstelijk, Hâtib Lanoeroe ${ }^{1}$, ende alle die van zyne zyde, hebben voor ons Orang Kaja's, Oelisiwa ende Oelilama, mitgaders de Hamba Radja Longa ${ }^{2}$, Birahi, ende Kaitsjili Singasari beloofd, dat wy den Kimelaha, Capitein Hitoe, Cambello, Oeli Anin, Oeli Laala, Henneteloe, Assahoedi, Erang ${ }^{3}$, ende alle wie den Prins van Holland, ende Konink van Ternate's vyanden zyn, niet aannemen, nog eenig gehoor geven zullen.

Ten tweeden, wy zullen die van de Papoewa's, Hatoewa, en Talemata, in onze negerye niet admitteren; nogte ietwat aan haar geven.

Maar wy zullen den Sengadji van Bonoa helpen gelyk getrouwe inwoonderen des Eilands Bonoa, en als de Heer Gouverneur, ofte des Koninks van Ternatens gezant, 't zy by dage, 't zy by nagte, by den Sengadji Bonoa komt, om corcorren, ofte volk te eisschen, om de Oelisiwa en Oelilima te volgen, wy zullen het naarkomen.

Ende daar na, indien Hâtib Lanoeroe, met de zijnen, alle deze voorstaande accoorden niet naarkomen, zullen dan alle de volkeren met de dood gestraft werden, zonder meer pardon te geven, alle haare goederen zullen verbeurd zyn aan de Oelisiwa's ende Oelilima's, ende alle haare thuinen, ende landeryen, zullen voor den Sengadji, ende de gene die hem volgt vervallen, aldus hebben wy dezen brief gesloten. Was geteekend, Pieter de Goyer, Jan Oetgerszoon, en uit naam van alle de Orangkaja's Joan Pays. ${ }^{4}$

\footnotetext{
1 De chatib (moskee-dienaar) van Lanoeroe?

2 Een Ternataan, door Hamdja bij zijn vertrek uit Ambon te Lesidi geplaatst (onuitgegeven missive van Ottens aan Antonie Caen, 29 October 1640).

$s$ De namen der voornaamste centra van verzet.

${ }^{4}$ De bekende Christen-inlander, die in de Ambonsche maatschappij een aanzienlijke plaats bekleedde en in de latere dagen, de dagen van De Vlamingh van Oudtshoorn, vooral zijn rol zou spelen (Vgl. Dagh-Register 1640-1641, bldz. 295; Bouwstoffen, III, bldz. 302; Valentijn, t. a. p. bldz. $133,161,187)$.
} 


\section{KUST VAN KOROMANDEL.}

October 1640. ${ }^{1}$

In denzelfden tijd, dat de Nederlanders zich vestigden op, en gaandeweg hunne betrekkingen uitbreidden met, verschillende streken van de Kust van Koromandel, deden dit ook de Engelschen. Het is niet te verwonderen, dat ook hier zoo goed als elders in Azië, bv. in den Maleischen Archipel, de mededinging niet steeds een viriendelijk karakter aannam. In 1626 bv. beklaagden zich de Engelschen bij de Nederlandsche autoriteiten te Batavia, dat de onzen op de Kust van Koromandel neenige verhinderinge tegen der Engelschen stabiliatie in Armigon, bij alle mogelijeke middelen aengeleijdt ende onderstaen hadden, haer door geschencken ende uijtgemaekte persoonen, alle obstaculen in hun voornemen voorwerpende, om soot' mogelijck waer, haere geintendeerde vestinge aldaer te weerhouden." Onze gouverneur-generaal antwoordde, dat hij dit niet wist, „maar wel dat d'Engelschen in Armigon alreede geseten waren, ende daer oock volck ende middelen hadden, om haeren handel te drijven", en tevens, dat hij bevel zou geven, „d'onse haer in 't minste geen empeschement souden bieden, ende soo sulck alreede mocht wesen onderstaen, dat d'selve in toecomende naelaten, ende bij alle mogelijcke middelen souden sien te redresseeren ...." Wat dan ook gebeurde bij schrijven van 28 October 1626 (Vgl. Dagh-Register 1624-1629, bldz. 291; Hunter, Gazetteer, III, p. 188, VII, p. 94; Birdwood, Report, p. 89, 214; Foster, Madras, p. 3; onuitgegeven missive van De Carpentier aan IJsbrandtsz. 28 October 1626).

Armigon of, beter, Armagaon (Armagon, Armeghon), ten Noorden van Pulikat, werd nu de hoofdvestiging (met een fort) der Engelschen op de Kust van Koromandel gedurende enkele jaren. Maar ook te Armagaon wilde het niet vlotten en in 1640 werd het verlaten en nu werd Madras hunne hoofdvestiging op de Kust (Foster, Madras, p. 3; Birdwood, Report, p. 216, Dagh-Register 1631-1634, bldz. 3, 7; 1640-1641, bldz. 87, 89, 184, v. 421). Terwijl dan in het begin van 1640 de Engelschen Armagaon verlieten, verkregen reeds in October van dit jaar de Nederlanders onderstaanden privilegebrief.

Caul door Willegotij Wenketapenaijk ${ }^{2}$, heer van Armogen, verleend in October 1640.

Gij moogt komen met UE. scheepen in mijne havenen Dangararasoepatnam $^{3}$ (dat is Armagom), Cottapatnam, Pondicrecorij,

1 Uit het Contractboek Zeeland.

2 „Desen sal apparent met bewilliginge des Konings een independent gebied gevoerd hebben" (Contractboek Zeeland). Deze koning zou dan moeten zijn geweest de vorst van Karnatika (Vijayanagar, Chandragiri, Vellore), maar het hoofd, de naïk, van Armagaon mocht zich in een feitelijke onafhankelijkheid verheugen (Vgl. Dagh-Register 1641-1642, bldz. 272, 274, 288).

3 Durgarayapatnam.

7• Volgr. III. 
0etecoer, Gangepatnam, Tommalapeenta ${ }^{1}$, en andere havenen, en daar ontladen ende laden uwe coopmanschappen en gij en zult nog van het laden nog ontladen der coopmanschappen iets betalen.

Ende waar dat ook uwe scheepen in onze havenen door ongeluk komen te breeken, het schip en goed sal UE. weder ter hand komen.

Dit caul heb ik gegeven, op dat het voor altoos zoo blijve.

\section{JAPAN.}

\section{November 1640. 2}

De Christenvervolgingen in Japan (vgl. hiervóór, bldz. 174, noot 1) hadden geleid tot de verdrijving der Portugeezen uit dat rijk in 1639 , krachtens decreet van 22 Augustus. De Nederlanders waren hierdoor bevrijd geworden van gevaarlijke mededingers in hunnen handel dáár, die gaandeweg ook na 1627 (vgl. hiervóór, bldz. 213) groote beteekenis had gekregen niettegenstaande velerlei moeilijkheden: vooral de xilver-export was van belang (Vgl. Nachod, Japan, S. 221, f., 225, f., enz.). Maar de maatregel, door de Nederlanders met vreugde begroet, bleek een tweesnijdend zwaard te zijn, dat ook tegen de onzen zoude kunnen worden gekeerd en hen zoude kunnen wonden, "want hadde d'ervarentheyt altyt geleert, dat, wanneer 't op de Portugesen regent, op de Comp' gemeenelyck mede al druppen wil." (Daghregister, 1640-1641, bldz. 149). En de onzen zagen het wapen ook al spoedig op hen gericht, zooals blijkt o. a. uit onderstaand "geboth des Keysers", dat den Nederlanders den 8 November 1640 te Hirado werd aangekondigd (Vgl. Heeres, Tasman, p. 42 ff.; Nachod, S. 199 ff.; Dagh-Register, 1624-1641, passim).

De Keyserlycke May ${ }^{t}$ is seeckerlyck geinformeert, dat ghy alle, als de Portugesen, Christenen syt; ghy onderhoudet den Sondagh; ghy schryft den datum van Christy geboorte boven op den top en de gevels uwer huysen, int gesicht ende oogen van onses geheele lants natie; hebt de 10 geboden, het Onsen Vader ende Gelooff, den doop ende breeckinge des broots, bibel, Moyses, propheten ende apostelen, in somma één werck; 't principael, dat blyft ${ }^{3}$; de

1 Wat deze plaatsen betreft, ben ik in het onzekere. Het is verleidelijk, daarin te zien Kottapatam ten ZW. van Mazulipatam, Pondicheri, Odecoet, ten W. van Pulikat, maar dit alles kan niet overeenkomen met het gebied, waarover de naik van Armagaon het bewind voerde, zelfs als men hem vereenzelvigt met den naik van geheel Nellore (Hunter, Gazetteer, III, p. 188, VII, p. 94).

2 Overgenomen uit Dagh-Register 1640-1641, bldz. 156. - Vgl. ook Valentijn, V, 2(Japan), bldz. 101.

s Valentijn: "blykt". 
verschillen tusschen beyden achten wy kleyn; dat ghy Christenen syt, is langh voor desen geweten, doch gemeent, eenen anderen Cristum had, waeromme gemelte Sijne May ${ }^{t} \mathrm{U}$ door my laet gelasten, alle Uwe woningen (geene uytgesondert), daer den datum, vooren verhaelt, opgestaen heeft, aff sullt breecken, beginnende van de noortsyde, welck het jonghste is gebouwt, ende soo voorts ten eynde toe ${ }^{1}$.

Uwen Sondagh en willen wy niet gedogen, ghy openbaer sult houden, opdat de gedachtenisse van dien naem ten eynde comt.

De capiteyn ofte het opperhooft van Uwe natie ${ }^{2}$ en sal voortaen niet meer als een jaer in Japan blyven ende jaerlyckx verwisselen, als die ${ }^{3}$ vau Macao gebruyckelyck geweest is, opdat, langer aliantie met de natie houdende, de leere niet werde uytgebreyt, want het contrarie geen gerustheyt geven can; 't volgende, waer nae U sult hebben te reguleereu, sal U naer desen door de Firandise regenten werden aengedient.

\section{BENGALEN.}

\section{Januari 1641. 4}

De Nederlandsche factorij te Pippli, waar ook Denen, Engelschen, Portugeezen, enz. handel dreven, mocht zich al spoedig in een zekere beteekenis verheugen. Reeds in 1640 was daar met den Bengaalschen handel gedurende één jaar een winst gemaakt van ruim f 26000 en G. G. \& R. spraken dan ook in 1639 van den progressieven stand van den handel op Bengalen. Bij het optreden van een nieuwen nabab wist de chef der factorij, Adriaan Helmont, de opvolger (1639) van Jacob Mahuysen, een nieuw - het onderstaande - "couwel" of ferman te verkrijgen "wegen den vryen handel in Pipeli ende Bengala, mitsgaders toezegging van allen behulp ende faveur." (Vgl. Dagh-Register 1640-1641, bldz. 91, 216 ; onuitgegeven schrïven van G. G. \& R. 1639; Bïdragen Hist. Gen., III, bldz. 344 v.v.).

Translaet uijt firman, door den nabab van Orixa aen $\mathrm{S}^{\mathrm{r}}$ Adriaen Mellmont 5, oppercoopman in Pipelij, verleent.

1 Onmiddelijk werd aan dit bevel voldaan (Nachod, S. 283, ff., Dagh-Register 1640-1641, bldz. 157).

2 In die dagen de bekende François Caron (3 Febr. 1639-10 Febr. 1641).

3 Nl. der Portugeezen.

${ }^{4}$ Uit het Contractboek.

5 Schrijffout voor: Hellmont. 
Dit is mijn firman, welck begeeren, dat alle gouverneurs, 's jonkaniers ${ }^{1}$ ende moradores ${ }^{2}$, die in de landen van Orixa resideren, sullen ter harte nemen; ende daerbij verstaen, dat $\mathrm{S}^{\mathrm{r}}$ Adriaen Hellmont, capteijn der Hollanders in Pipijlij, ons comende verwellecommen ende begroeten, dit firman tot versterckinge haerluijder negotie van onsen handen versoght heefft, ons te kennen' gevende wat vrijdommen voor desen genoten hebben; mitsdien met de Hollanders omme haerluijden verder contentement te doen ende onse landen door haren handell florisanter te maeken in een nieuw contract getreden ben, namentlijek:

Ter wadt plaetse en havenen in Orixa haerluijder schepen soude mogen aencomen, sijlieden haere goederen ende volck sullen vermogen te lossen ende aen landt te brengen, sonder eenige de minste verhinderinge offte ondersoek van jemandden, ende soo wanneer eenige goederen willen affscheepen ende daermede vertrecken, sall haerluijden niet meerder als met desellve gecontracteerdt hebbe, affgevordert werden. Jngevalle hare aen te brengen coopmanschappen in Pipelij niet en cunnen vertieren, mitsdien genoodsaeckt werden d'sellve naer andere plaetsen landtwaerdt in te vervoeren, omme aldaer beter avantagie aen te treffen, sullen met betalen van 3 perc $^{10}$ eens mogen vollstaen ende haer lieden alls dan een cedulle offte passe verleent werden, ter wadt plaetsen sijlieden passeeren en die goederen vervoeren, vrij en liber van alle verdere tollen en s'jonkannen zijn zullen; ook op aencomste van hun schepen offte jaghten van jder, zij cleen off groodt, niet meerder gehouden zijn te bethalen als 300 ropias eens, sonder eenige andere cosstumen offte nieuwigheden, hoedanigh die genoempt moghten worden, subject te sijn; hare goederen, t'zij naer Narraijngerra $^{3}$ vervoerende offte van daer brengende, zullen van seven gedeellten een gedeellte vrij hebben ende sulx niet meerder als van de ses sevende gedeellten gereggtigheijt betalen, ten ware andere cooplieden den $\frac{1}{4}$ gelargeerdt wierden, als wanneer mede d'sellve vrijdom sullen genieten. Van alle cleeden, suijckeren, sallpeter, wasch ende andere coopmanschappen, wellcke zijlieden landwaerdt in souden mogen procureeren en naer Pipelij begeeren te vervoeren, sullen niet meerder als 3 ten hondert betalen, sonder dat ijmandt

\footnotetext{
1 Belastingambtenaren?

2 Het Port. "moradór" = inwoner, ingezetene?

3 Narayangarh (bij Valentijn: Nareinger), ten Noorden van Pippli, aan een zijtak der Haldi.
} 
hare goederen vermagh te openen offte besightigen, maer sullen op haer lieder simpell aengeven volcomen gelooff meriteeren. Soo nu echter eenigh ander vermoeden was, sall maer een pack ende niet meerder van jder specie mogen geopent werden. Hare goederen sullen vermogen t'jmbarqueeren ende met alle cooplieden tharen huijse te handelen naer believen, sonder van jmandtden daerinne getouleerdt (?) offt verhindert te werden. Eenig goudt offte sillver aenbrengende, vervoerende offte verhandelende, sullen daer van geen gereghtigheijt betalen, maer volcomen exempt zijn; t'jnvorderen van hare uijtstaende schullden sullen ook int minste niet geobsteerdt maer, des noodigh ende versoght zijnde, de schulldenaers bij weijgeringe van betalen in hare handen gelevert werden, mits dat desellve schulldenaers met hare schepen niet en sullen vermogen te vervoeren; sall mede van haren handell, 't zij vercoop offte jncoop, tharen huijse geen ondersoek noghte aenteijkeninge door eenige maeckelaars offte anderen gedaen, maer in haren opreghten handell volcomen gelooff gegeven werden. Van de goederen, die met hare schepen aenbrengen, lossen ende bij invenditie offte anders weder willen jmbarcqueeren, zullen geen tholl betalen. Haerlieders dienaers eenige misdaet plegende, uijtgesondert van dootslagh, diverije ende diergelijcke capitale, sall den Gouverneur d'selve niet vermogen in apprehentie te nemen, veell min daer over te straffen maer tot dien eijnde aen de capitteyn der Hollanders geintregeerdt werden, omme hare verdiende straffe t'ontfangen; dogh sulcx niet geschiedende, sall den Gouverneur sigh ook sodanige saeke mogen aentrecken. Soo 't geviell, de Portugesen te lande offte die van de sjeliase ${ }^{1}$ eenige quetsie ende force tegen d'Hollanders attenteerden ende de Hollanders sigh daer over willden revengieren, sall den Gouverneur sigh daermede niet te bemoeijen hebben, maer haerlieder saeke naer begeeren laten hanthaven ${ }^{2}$. Eijntelijck confirmere noghmaell, d'Hollanders tot egene plaetsen eenige thollen noghte sjonkannen anders als in Pipelij ende Narraijngerra, sulx hier vooren gespecificeerdt, affgevordert sall werden. Soo nu eghter jets contrarie desen ende haerlieden daerover molesste geschiede, sullen d'overtreders tot exempell van andere ten hoogsten gestrafft werden.

1 Galjas? - „Gelias, sijnde een slach van cleene smalle doch lange vaertuygen, de fregatten niet seer ongelijek, doch worden met 16, 20 ofte meer riemen voort geroeyt, soo snel dat het te verwonderen is" (Bijdragen Hist. Gen., III, bldz. 347).

2 Vgl. hierbij Dagh-Register 1640-1641, bldz. 216. 
Zijnde dit mijn firman ende bevell, welcke begeere geobdieert ende naergecomen sall werden.

Gegeven den $28^{\text {en }}$ dagh der maendt Ramsan ', jn den jaere 1050 naer Machomets tijde, zijnde naer onse reecqeninge $10^{\mathrm{e}}$ Januari des jaers onses Salighmaeckers Jesu Christij A ${ }^{\circ}$ 164l.

\section{GOA.}

26 Maart 1641. 2

Den 14 Januari 1641 werd Malaka door de Nederlanders veroverd, en daardoor de politieke macht der Portugeezen, voor zoover den Archipel betreft, tot de Solor- en Timorkwartieren beperkt. In het Westen van Azië zat thans nog de kracht onzer mededingers en dáár was Goa, de hoofdstad van Portugeesch Indië, tevens het centrum dier kracht. Daarop waren dan ook reeds geruimen tijd ernstige aanvallen der O. I. C. gericht (vgl. hiervoor, bldz. 295); dáár kruistte thans "de vlote van defensie", die een vloot van offensie was, onder bevel van Dominicus Bouwens, die in October 1640 voor Goa verscheen. Juist hadden de Portugeezen versterkingen van beteekenis ontvangen (Vgl. Dagh-Register 1640-1641, bldz. 18, 67, 190, 191, 219; Valentijn, V, b, Malabar, bldz. 27 v.v.). Zooals bekend is, is geen sprake geweest van het bemachtigen van Goa. Onderstaande overeenkomst heeft dan ook nooit uitwerking gehad: hoogstwaarschijnlijk waren de onderhandelingen daaromtrent van de zijde van den Portugeeschen verrader niet gemeend (Vgl. aan het slot).

Contract gemaect tusschen den bisschop van Zallcedo ${ }^{3}$, don Mattheo de Castero, ter eender ende den Ed. Command ${ }^{r}$ Dominicus Bouweus ende zijnen Raedt wegens d'Oost-Indische $\mathrm{Comp}^{\mathrm{e}}$, ter ander zijde.

Eerstelijck dat bij + bisschop, sall leveren en in handen stellen het fordt op de Aguade ${ }^{5}$.liggende ${ }^{6}$ de Hollanders; mits dat hij

1 Ramadhan 1050 begint met 15 December 1640.

2 Uit het Contractboek.

s Het eiland Salsette, ten Noorden van Bombay, een bloeiende Portugeesche bezitting en kolonie (Hunter, Gazetteer, VII, p. 137 f.), of de landstreek Salcette ten Zuiden van Goa (Vgl. de Map of the Portuguese territory of Goa in Danvers, Portuguese, II).

4 Schrijffout voor "hij."

5 Agoada ten Westen van Goa, aan de Agoada-baai, op de Zuidwestspits van de landstreek Bardes. Zie de Map bij Danvers. Vgl. Valentijn's kaart van Koromandel en Malabaar (in deel V, 1).

6 Is hier het woordje naen" uitgevallen? 
dan liberteijt van religie offte godsdienst sall mogen exerceeren ende laten oeffenen; daer en boven alle incomen der geestelijcke goeperen voor hem in propria genieten.

De mogadon ${ }^{1}$ Serdiseijt, jegenwoordigh overste van 't voorschreven forten d'Aguada, sall all de goederen van de blaucke Portugesen, op de Bardes woonende, genieten, maer tollen, imposten etc $^{\mathrm{a}}$, als voor desen aen de Maijesteijt van Spanjen is gedaen, sullen betaelt en opgebraght worden aen de Hollanders.

Tot belooninge, naer verrighter saeken deses faicts, sall den gecommitteerden van den Bischop, Babijsianeijk ${ }^{1}$ genieten d'jncomste van een der beste ende rijckste dorpen op 't eijlandt van Goa liggende, maer de stadt van Goa en aencleven van dien vorders ter eijgendom voor de Compagnie.

Ende vermits gemelte bisschop eenige verhoolen gelt in Goa te zijn seght en oock te willen aenwijzen, waer 't sellve is, sall bij veroveringe daervan de gereghte hellfft vooor hem en d'ander voor de Compagnie wesen en gereparteerdt worden.

Adij 26 Martij $\mathrm{A}^{\circ}$ 1641. Int schip Amboijna ter rheede voor Wingurla. Was onderteekent Dominicus Bouwens, Jan Jsbrantszoon Jongh, Gerritt van Harn, Cornelis Clasen Staets, Floris van Cassel, Pieter van de Camer, Aris Neijgh, Zweer Momenszoon, Jacob Nollpee, Dirck Janszoon Bolles, Raedt en Secretaris. ${ }^{2}$

1 ?

2 Hoe G.G. \& R. over deze overeenkomst dachten, blijkt uit hunne instructie van 11 Juli 1641 voor Matthijs Hendrikszoon Quast, toen naar Goa met een nieuwe vloot gezonden. „D'onderhandelingh ende 't contract met (den) Bisschop van Salcedo is ons met reden suspect, te meer 't selve soo ruchtbaar sy, den Portugees daer van niet onwetend can wesen, ende dewijle desen persoon ongemollesteert laten, moeten over sulcx crachtelyk besluyten, onse vyanden daermede voordeel doen, ende uyt dese negotiatie alle desseynen ende gelegentheyt trachten t'ontdecken, des oock t'onbeschroomder Ceylon gesecoureert ende Goa van volck geheel ontbloot hebben, soo dat van desen Bisschop ende sijn voorgeven niet te veel staat dient gemaekt, hem noch den synen veel crediets te geven opdat niet bedrogen worden, waerop vertrouwen, dese onderhandelingh van d'andere syde eenelyck aenleggen: echter dient als noch niet geheel voor 't hooft gestooten, maer met discretie aengehouden." - Deze instructie is afgedrukt in deze Bijdragen, Nieuwe volgreeks, II, bldz. 320, v.v. Op bldz. 329 staat daar een komma geplaatst tusschen "moeten" en "over." In het manuscript bevindt zich deze komma niet. Het komt mij voor, dat zij moet geplaatst worden tusschen "laeten" en "moeten": de zin loopt dan beter. Ik heb mij dan ook de vrijheid veroorloofd, haar dáár te plaatsen. 


\section{JAPAN.}

11 Mei 1641. 1

François Caron (zie hiervóór, bldz. 340) werd als „opperhoofd van 's Compes comptoir in Japan" in Februari 1641 opgevolgd door Maximiliaan Lemaire (tot 1 November 1641). Spoedig na zijn optreden vertrok hij naar Yedo, „om de jaerlijexe reverentie en geschencken persoonelijck ten hove te doen" (de z.g. hofreis). „Wegen de Keijserlijcke Maij"” werd hem den 11 Mei het volgende medegedeeld (Dagh-Register 1641-1642, bldz. 65, v.; Nachod, Japan, S. 290-297): het was het bevel tot overbrenging der factorij van Hirado naar Nagasaki.

UE. presenten aen de $\mathrm{Maij}^{\mathrm{t}}$, die wij ${ }^{2}$ uijt sijnen name alsnu aenvaerden, zijn aengenaem.

Denselven laet UE. door ons aenseggen, alhoewel 't rijcke van Japan daer weijnich met beholpen is, ofte de vreemdelingen daerinne negotieren ofte niet, dat echter de Hollanders ten respecte van de passe hun lieden door den ouden Keijser verleent ${ }^{3}$, daerinne mogen handelen en blijven genieten, int stuck harer commertie als alle andere saken, de voorjarige vrijheden, maer dat gehouden zullen zijn, hare schepen voortaen in Nangasacque ${ }^{*}$ te doen havenen, met hunnen gantschen ommeslacht uijt Firando opbreecken ende die aldaer te transporteren, also Sijne Maijt verstaet, egeene vreemdelingen in sijn rijck anders als in voorschreven plaatse te gedoogen.

Soo UE. scheepen int vaerwater van Maccau ende Manilha herwaerts ofte omtrent dese custe eenige Portugiese ofte Castiliaense galiotten, die d'ooge ${ }^{5}$ mochten hebben om hen papengebroet alhier aen lant te setten, comen te achterhalen, mogen deselve wel vijandelijck aentasten, veroveren ende in Japan brengen, waeraan de Maijt ${ }^{t}$ grooten dienst geschieden, ende de Hollanders seer aengenaem maken sal, bijsonder soo de papen als andere geestelijke personen oprechtelijck door hun lieden aengewesen conden werden. ${ }^{6}$

1 Overgenomen uit Dagh-Register 1641-1642, bldz. 66.

2 Nl. de Japansche ambtenaren, door wie Lemaire te Yedo werd ontvangen.

3 Vgl. Nachod, S. 296.

4 Over eene verplaatsing onzer factorij naar Nagasaki was reeds vroeger door de onzen gedacht, omdat men daarvan zekere voordeelen verwachtte. Zij op zich zelve was dus geen nadeel (Nachod, S. 232 ff., 296; Dagh-Register 1641-1642, bldz. 67).

5 Oogwit, bedoeling.

${ }^{6}$ "Waer op $\mathrm{S} r$ Le Maire nae overlegh met de tolcken t'naervolgende reverentelijek geantwoort hadde.... Dat 's Keijsers ordre van uijt Firando op te breecken ende in Nangesacque ons te sullen moeten transporteeren, promptelijek souden achtervolgen.

Insgelijex onse schepen soodanich Portugies ofte Castiliaens vaertuijch in handen vallende, bereijt bleven d'ordre van sijne keijserlijeke Maijt daerinne naer te komen." (Dagh-Register 1641-1642, bldz. 67). 


\section{ATJEH. - SUMATRA'S WESTKUST.}

\section{Februari-Mart 1641. ${ }^{1}$}

Na het contract van 17 Januari 1607 (hiervóór, bldz. 48) hadden de verhoudingen tusschen de O. I. C. en Atjeh wel allerlei phases doorloopen, maar - zij het dan met tusschenpoozen - de handels- en staatkundige betrekkingen tusschen beide waren gebleven. Het is bekend, dat vooral drie aangelegenheden bij het voortbestaan dier relaties waren betrokken: onze handel met Atjeh zelf, die met Sumatra's Westkust, waar Atjeh in de eerste helft der 17 de eeuw zich had gevestigd en gaandeweg uitgebreid en de vraag, wie invloed zoude uitoefenen over Straat Malaka, en, daarmede in verband, op het Maleische schiereiland. Van een versterkte plaats in Atjeh, waarvan het contract van 1607 sprak, had Iskander Moeda, de opvolger van den sultan, die het privilege had geschonken, niet willen weten en ook overigens was men aan Sumatra's Noordkust hoe langer hoe minder geneigd, het gezag der O.I.C. uitgebreid te zien, hoe langer hoe meer, zich daartegen te verzetten. Vooral toen de krachtige Iskander Moeda (in 1607) op den troon kwam en het rijk uitbreidde ver buiten de grenzen van oorspronkelijk gebied, op Sumatra's Westkust en het Maleische schiereiland. Noch hij, noch zijn opvolger, bleken ten slotte genegen, mèt ons op te trekken tegen het Portugeesche Malaka, dat dan ook door ons werd veroverd met hulp van Djohor, maar zonder assistentie van Atjeh (Tiele, Europeërs, VII, bldz. 120; VIII, bldz. 164, v.; IX, bldz. 243, v.v., 303, v.; Bouwstoffen, I, bldz. II; dl. II, passim; Dagh-Registers, passim). Zijn opvolger en schoonzoon overleed den 15 Februari 1641 en nu kwam de tijd eener vrouwenregeering, ingewijd door een dochter van Iskander Moeda, weduwe van diens opvolger. In de eerste dagen van haar bestuur verscheen in haar rijk een gezant der O. I. C. - een der vele gezanten naar Atjeh uit Batavia van die dagen - Joost of Justus Schouten. Hij wist den volgenden privilegebrief te verwerven (Bouwstoffen, III, bldz. II v.v., VI, v.v.; Dagh-Register 1640-1641, bldz.422, v.v.), waarbij enkele vroegere voorrechten ${ }^{2}$ werden bevestigd.

Translaet uyt 't Maleys vant firman ofte schriftelycke acte der koningine van Atchyn, nopende 't confirmeeren van des Comp ${ }^{\text {es }}$ preminentien in hare May ${ }^{\text {ts }}$ Coninckryck.

\section{By gratie vanden Almachtigen Godt comt dit schriftelyck man-}

1 Overgenomen uit Dagh-Register 1640-1641, bldz. 425.

De datum moet gesteld worden tusschen 23 Maart en 27 Mei (Vgl. Dagh Register, bldz. 423 jo 425).

a Vgl. b.v. Bouwstoffen, II, bldz. 354, v. - Ik neem die „benefitien" hier niet op (ofschoon zij meestal als een contract worden beschouwd door andere schrijvers), omdat zij niet geteekend zijn geworden door den Sultan, vermoedelijk zelfs niet officieel op schrift zijn gebracht. 
dament van my Mahamoulia 1, Bava Dely Hallarat 2, Paducka Sirj Sultan Ma-alam Walchaca, Nul Mackaram, Siate Berdouleth " , jang diatas tachta garadien Atche Darou Salem *, Jala Chalipha Tolla 5, blinckende als de sonne. Ick, Coninginne van Godt uytgelesen en boven alle andere gestellt, Coninginne door successie , rechterlyck naevolgende de vorige Coningen etc., gaet dit myn mandament aenden orangcaya Paducca Siry, radja Panglima Bandaer Calipha ${ }^{6}$; den orangcaya Siry radja en orangcaya besar radja Indra Moeda, radja Sittia Wangsa, radja Indra Macotta, radja Lalangh Toon Pate en Sanglielie ende aen Siribidj d'radja Panglima Priaman, den Maradja Ananda en orangcaya Sry Amar Bangsa deradja Maradja moeda, radja Amat, maradja Srydewa, radja Indra Moeda, Sirj radja Sittia Leladeradja, Maradja Indra en Maradja Istja ende aen radja Indra Wanghsa Panglima Indra Poura en radja Mangsor, radje Moedasar Permey de Wangksa ende aen Bendhara Segol Eselam Panglima Padangh en dato Besar, dato Moeda, Radja Palawan, nachoda Caya ${ }^{7}$, mitsgaders aen alle de grooten en vassalen van myne steeden aldaer. ${ }^{8}$

Ghylieden sult altsamen weeten:

dat wy den Capiteyn Generael genadelyck ontslagen hebben van den tol van een schip, handelende in Ticou, Priaman, Indrapoura en Padangh; gelijck Paducka Morhom Darou Salem ${ }^{9}$ dit genadelijck aen den Capiteyn Generael heeft verleent ${ }^{10}$ met Godes beliefte, soo vergunne ick nu als Coninginne, van Godt gestelt, 't selve aen den Cap $^{\mathrm{n}}$ Generael.

Item als andere Hollantsche scheepen in Ticou, Priaman, Indrapoura en Padang comen negotieeren, zullen haeren tol met realen piddangh ${ }^{1} 1$ betaleu.

1 In 't Dagh-Register vertaald door: "de hoochgeachte".

2 "Daelende van myne hoogheyts gratie."

3 "Syn haere Conincklycke namen".

" "Die op den throon (tachta karadjaän) van Atchin sidt."

5 "Coninginne van Godt in dit Ryck gestelt."

" "Ticou" (op Sumatra's Westkust).

$7 \mathrm{Ik}$ heb niet de moeite genomen, de namen van al deze grootheden terecht te brengen. De titels zijn duidelijk te ondersoheiden.

${ }^{8}$ Natuurlijk van Sumatra's Westkust.

? Haar voorganger en echtgenoot (Bouwstoffen, II, bldz. 74, noot 1), Iskander Tsani.

10 Vgl. Bouwstoffen, II, bldz. 355, sub $5^{\circ}$.

11 "Rycxdaelders." 
Item sal geen handel aen Denemarcken, Engelsen en Fransen scheepen in deze vier genoemde steeden vergunt ofte toegelaten werden. ${ }^{1}$

\section{PALEMbang.}

\section{Juni 1641. 2}

De eerste aanrakingen der Nederlanders met Palembang dagteekenen waarschijnlijk van 1616. De toenmalige vertegenwoordiger der O. I. C. in Djambi, Andries Soury, zond toen (in April) „een schenckagie aen den Coninck van Palimban" door diens in Djambi vertoevende gezanten. De Pangeran wilde handelsbetrekkingen met de Nederlanders aanknoopen. Ongelukkigerwijze zette het onhebbelijk optreden van Nederlandsche vaartuigen tegen Palembangers, o. a. tegen naar Djambi gezonden gezanten, kwaad bloed. Coen trachtte hierin te voorzien en in $1617 \mathrm{ging}$ Crijn van Raemburch in overleg met Soury naar Palembang, waar hij vriendelijk werd ontvangen en waar hij ook aantrof den koning van "Banque" (Banka), schoonvader van Palembang's vorst. Men hoopte, in Palembang te kunnen opkoopen benzoë, drakenbloet, was, olifantstanden, peper, hout. De commercieele betrekkingen bleven voortduren en in 1619 werd, nom de vruntschap te onderhouden ende notelyckheden te becomen daer (een) assistent gelaten." Sedert was dus eene Nederlandsche factorij te Palembang gevestigd. Wel werd zij reeds in 1621 weder gelicht met het oog op Coens plannen, den handel zooveel mogelijk in enkele centra te trekken, maar de betrekkingen werden niet afgebroken. De wijze, waarop de Nederlandsche zoogenaamde "vrye luyden" de wateren ten Oosten van Sumatra onveilig maakten (vgl. ook hiervóór bldz. 291), bracht de Hooge Regeering in moeilijke verhouding, ook tot Palembang, en in 1622 werd een gezantschap gezonden door Coen, nomme met vrientschap en een goede vereeringe bij de Coninck ende grooten te versoeten ende excuseeren de groote faulte door de vrye lieden aen haer volck begaen", wat dan ook gelukte, althans wat de schijn aanging: vergeten toch werd "d'outrage" niet en de onzen moesten zelfs in Djambi op hoede zijn tegen Palembang, al bleef uiterlijk de verhouding vriendelijk (Vgl. Mac Leod, O. I. C. op Sumatra, in Ind. Gids, 1903, bldz. 1250, v.v.; onuitgegeven missives van Soury aan Coen, 15 Juni, 2 Juli, 27 Nov. 1616; van Coen aan Soury, 4 April, 23 Mei 1617; var Crijn van Raemburch aan Coen, Sept. 1617; van Coen aan Bewindhebbers, 22 Jan. 1620, 16 Nov. 1621, 6 Sept. 1622, 20 Juni 1623; aan J. Jzn. Hoochlant te Palembang, 2 Sept. 1621; aan B. Kunst te Djambi, 24 Maart 1626, enz.). Later kwamen de betrekkingen gedeeltelijk onder den invloed - het is bekend - van die met Djambi, met Mataram; een intermezzo was onderstaande overeenkomst (Vgl. Bouwstoffen, II, bldz. XXIV-XXXI; dl. III, bldz. II, XLII, 38, waar dit contract is afdrukt; Dagh-Register, passim; onuitgegeven missive van Pieter Soury te Palembang aan Van Diemen, 19 Juni 1638;

1 "Nota, d'originele acte is sonder datum, maer met der Coninginnen grooten segel bevesticht."

2 Uit het Contractboek. 
Generale missive, 18 Dec. 1639; G.G. \& R. aan Pieter Soury, 17 Juli, 2 Oct. 1640, Mac-Leod, t. a. p., bldz. 1915, v.v.).

Ten tijde als wanneer den capiteyn Soerij was gesonden van wegens den Capiteijn Moor Anthonio van Diemen omme te overhandigen twee stucken geschut neffens 20 stx mussquets ${ }^{1}$, heefft den pangeran van Palimbangh geaccordeert omme een plaets in Palembangh te kiesen omme een goedongh daer op te maeken op allsulcke plaets als zall begeeren: dit is t' ackoordt dat den pangerangh van Palembangh heefft gemaeckt met den capiteyn Soerij int jaer Gingh in de maendt Radeap den dagh van Jssemeij. ${ }^{2}$

Wijders heeflt capiteyn Soerij veraccordeert dat in de gedongh sall stellen aght groote stuckken geschut. Doorsaek dat het geschut daer will stellen is offer eenige Portugeesen quamen om de gedongh te willen affloopen offte ook die van de Mattaram offte eenige dieffaghtige menschen off ijmandt anders die haer luijden eenigh leedt willde aendoen, want alle de roovers van die van Palembangh mede roovers van de Hollanders zijn. Te deser tijt is geweest sabandhaer Valerius Gentill ${ }^{3}$. Daerom heefft te deser tijt den Pangeran dit schrifft verseegelt verleendt.

Batavia desen $21^{\mathrm{e}}$ Junij A $\mathrm{A}^{\circ} 1641 .{ }^{+}$

1 Pieter Soury had in de laatste jaren verschillende malen Palembang bezocht, minstens sedert 1637 .

2 November 1640. - Radjab 1050 begint den 17 Oct. 1640. - Bij (onuitgegeven) instructie van 20 Juni 1640 had de G.G. aan Soury gelast, dat deze niet moest ingaan op het verzoek van den Pangeran, om daar „permanente residentie" te houden, tenzij wij verlof kregen, goede sterkten te bouwen, om den Vorst tegen diens vijanden te verdedigen, en onder voorwaarde van het pepermonopolie: „bij aldien deze of diergelijcke discourssen voorvallen, sal UE. op de mine ende derselver antwoorde goed regard nemen." De Pangeran, die toen met Bantam in oorlog was en Mataram en Djambi meende te moeten vreezen, was niet afkeerig van dit denkbeeld en stond ons toe, als wij een woning in zijn rijk wilden bouwen, dit te verzekeren met 8 stukken "groff canon" (onuitgegeven Generale missive 8 Jan. 1641). Een bepaalde bindende overeenkomst is niet gesloten in Palembang (Zie beneden, noot 4).

s Bij zijne instruetle van 20 Juni 1640 was aan Soury uitdrukkelijk gelast, dezen te vriend te houden. Blijkbaar een Portugees, evenals trouwens de gezant van Palembang te Batavia een Portugeeschen naam draagt, Pasqual Rodrigues d'Andrade (Dagh-Register 1640-1641, bldz. 273, v.v., 348).

4 Dit schijnt de datum te zijn der voorloopige bekrachtiging van de overeenkomst te Batavia of der overhandiging aan den G.G. door den gezant d'Andrade. Een voorloopig karakter droeg het stuk in elk geval. Want zoowel in een nieuwe (onuitgegeven) instructie voor Soury van 26 Juni 1641, als in die voor zijn opvolger Adriaan van Liesveld van 19 Nov. 1641 wordt uitdrukkelijk door G.G. \& R. gezegd, dat men den Pangeran moet mededeelen, dat zijn begeeren zal ingewilligd worden. 


\section{MALAKA.}

\section{Augustus 1641. 1}

Malaka was den 14 Januari 1641 veroverd, na een insluiting van een achttal jaren (sedert 1633) en een eigenlijk beleg van bijna een half jaar (Vgl. Bouwstoffen, II, bldz. LXXXI, v.; deel III, bldz. XII, v. v. en verdere bekende bronnen en litteratuur, als het Dagh-Register, enz.) Een van de vele zorgen, welke den eersten Nederlandschen gouverneur der vesting, Johan van Twist, bezig hielden, was de verhouding tot de omliggende Maleische stammetjes. „Nae verscheyde conferentien ende raetslagen", werd o.a. met het naburige Naning „ende d'omleggende dorpen" in Augustus 1641 onderstaand "accord getroffen", dat de Nederderlandsche suprematie over die streek in rechte vestigde in plaats der vroegere Portugeesche (Dagh-Register 1640-1641, bldz. 367, 460, waar het contract is afgedrukt; $1641-1642$, bldz. 78).

Artijkelen ende conditien geaccordeert, beslooten ende geresollveerdt tusschen den E. Joan van Twist, extraordinaris Raedt van Indien ende gouverneur over de stadt ende fortresse van Malacca sampt syn Ed ${ }^{\text {es }}$ Raden ter eenre, ende Toulella Palawan, capiteijn, ende radia Mera, Perpatij, Lowatan, Maranga, Mattamarra, ende Bansa deraije ${ }^{2}$, ousten van Naningh ${ }^{3}$ met d' omleggende dorpen ter andere zijde.

In den eersten beloven ende sweeren de voorschreven capiteijn ende ousstens uijt den name ende van wegen de geheelen menighte, de doorlughtige Hoogh ende Mogende $\mathrm{H}^{\mathrm{rn}}$ Staten Generael van de Vereenighde Nederlanden, Zijn Hoogheijt ende Vorstelijcke Genade Frederick Hendrick, prince van Orangien etca, de Bewinthebberen der Vereenighde Oostindische Comp ${ }^{e}$ jn dese landen, den Ed ${ }^{\text {en }}$ Heer Gouverneur Generael ende Raden van Jndien, mitsg ${ }^{\mathrm{ds}}$ hier ter stede den E. Heer Gouverneur ende zijne Raden, jtem alle bevellhebberen die over haer gestellt offte naermaels mogen gestellt werden, gehouw en getrouw te zijn ende een ijder naer zijn uijterste vermogen in alle behoorlijcke onderdanigheijt tot den Nederlandschen staet te draegen als getrouwe vassalen schulldigh ende gehouden zijn, sonder tegen deselve staet jets voor te nemen directelijck offte jndirectelijck,

1 Uit het Contractboek.

${ }^{2}$ De namen zijn iets anders gespeld in het Dagh-Register. - Radja Mera wordt ook wel "hoofd van Naningh" genoemd (Dagh-Register 1640-1641, bldz. 357). - Palawan is zeker het bekende pahalawan = krijgsoverste, enz.

${ }^{3}$ Ligt ten Noorden van Malaka en is thans een der z. g. Negari Sambilan. 
derogerende ende te niet doende alle contracten ende verbanden met de regeerders van den coninck van Hispanien offte Portugesen voor desen gemaeckt.

2 .

Ende jngevalle ijmandt vant volck van Naningh, kinderen van de Manicabers ende Maleijers ${ }^{1}$, tegen den jnhoudt van dit contract quamen te verlopen offte de heeren Gouverneur ende desselffs officieren ongehoorsaem waren, sullen de voorschreven capiteijn ende outsten gehouden weesen, denselven ter aenmaningh van den tomagon ${ }^{2}$ off fiscaell over te leveren, om bij gemellte gouverneur ende Raedt naer verdiensteu gestraffte te werden.

3.

Comende een Manicaber, sijnde jnwoonder van Naningh, t' overlijden souder vrou, kinderen offte wettige erffgenaemen naersaten ${ }^{3}$, sall de Compe als ten tijde der Portugesen gebruijckelijck is geweest, van desselffs naer te laten goederen genieten de helfft ende de capiteiju van Naningh van gelijcken tauder deell; ende erffgenamen als voorschreven hebbende, het tiende deell ende $*$ erffgenaemen $*$ waervan de Capiteijn de helfft geniet.

4.

Wanneer eenige Manicabers, jnwoonders van gemelte Naningh, den anderen comen te doden ende de dader hem op de vlught begeefft, sal de Compe genieten alle desselffs goederen, niets uijtgesondert, ten ware den deliquant vrau offte erffgenamen naer lieten, die de helfft behoudt, als voren vau de overleden geseijt is.

5 .

D'voorschreven capiteijn en outsteu, mitgaders d'jnwoonders van Naningh, zoo Manicabers als Maleijers, blijven gehouden van de

1 Doelt dit op den oorsprong der bevolking van Naning? Met Manicabers (= Menangkabauers) duidde de Portugeezen óók de bewoners van het Maleische schiereiland aan (Bouvstoffen, II, bldz. 246, noot 1). Maar wie worden hier dan bedoeld met de Maleiers? Trouwens ook de Menangkabauers van Sumatra's Westkust worden in de spelling der O. I. C. tot Manicabers verknoeid (b. v. Dagh-Register, 1661, bldz. 453).

2 Toemenggoeng (Vgl. o. a. Van den Berg, Rangen en Titels, bldz. 53).

3 Dagh-Register heeft : "naer laten".

4 Deze beide woorden heeft het Dagh-Register niet. 
rijssvellden ende alle andere vruchten ande Generale Oosst-indische Comp $^{e}$ te geven de thiende dersellver. Item van de betele ende peper thuijnen jaerlijcx soodanige rente als naer groote dersellver voor desen is gebruijckelijck ter arbritrage van den valiadoor des hortes ${ }^{1}$ ten overstaen van de gemaghtigdens vau de Comp ${ }^{2}$ ende de voorschreven jnwooonderen; $d^{\circ}$ thuijnen onder den anderen vercoopende, sullen gehouden geweseu aen de Compe offte hare gemaghtigens te betalen den $10^{\mathrm{n}}$ dersellver in contant, gelijck voor dese costumelijck.

6.

Mits ${ }^{3}$ dat ten tijde van de versamelingh de voorschreven Nederlandsche Oosstindische Comp ${ }^{e}$ deselve gehouden blijven, aen de voorschreven gaerders te verstrecken 200 gantangs melie ${ }^{+}$off ongestooten rijs tot hun onderhoudt neffens een stuck lijnwaet ende cassa 5 tot erkenteuisse aen den capiteijn van gemelte Naningh.

7.

De voorschreven neellje all ${ }^{6} \mathrm{t}$ gellt van thuijnen ingesamellt weseude ${ }^{7}$, den Capiteijn van de voorschreven jncomste genieten het thiende deel, soo aen waren als gellt, gelijck voor desen gebruijckelijck, mitsgaders deu schrijver van $d^{\circ}$ capiteijn 5 crusados ${ }^{8}$ ende den prijsseerder van $d^{\circ}$ tuijnen ende voornoemde neellje 5 gelijcke. crusados, eens voor haere gagie sonder meer.

\section{8.}

Eenige vaertuijgen met betele van Naning comende, zijn gehouden te blijven leggen aen de bancksaell ende voor gerechtigheijt te betaelen van duijsent, houdert bladen $d^{\circ}$ betelen; van gelijcken voor ijder prauw een crusado ten behoeve van meergemellte Compe. Item voor den dienaer van den ontfanger off sabander hondert

1 Valiador dos hortos: schatter der tuinen.

2 Dagh-Register heeft hier de punt-komma. Misschien moet zij staan achter „jnwoonderen".

3 Dagh-Register: "mitsgaders".

"Dagh-Register: "neelie".

5 Een soort katoenenstof.

"Dagh-Register: "als".

7 Dagh-Register: "sal".

8 Een crusado: in Valentijns tijd $\frac{3}{4}$ reaal (Batavia, bldz. 357); gewoonlijk lager: $\mathrm{f} 1.25$ ongeveer. 
bladen uijt elcke sack beteele; hoenders, toeback ende melck in bamboesen uijtgenomen, die 'van eenige lassten sijn except geweest.

9.

Mits dat voornoemde tomagon offte ontvanger verobligeerdt blijfft, gestadigh te houden een dienaer in de bancksaell, die ook het volck, met de voorschreven vaertuijgen affcomende, moet versorgen van potten, schotelen ende waterpotten, een paringh om houdt kappen ende kaerssen off lampen; jtem tweemaell eten, jder persoon een schoupa, dat is $1 \frac{1}{2} \mathscr{H}$, rijs; ende voorts soute offte varsche vis ende groente naer advenandt, blijvende de vordere montcossten bij langer vertrouwen ${ }^{1}$ aen de bancksaell ten lasste van de gemellte persoonen.

10.

Ende wanneer eenige ${ }^{2}$ prauwen van de $\mathrm{Comp}^{\mathrm{e}}$ in Pancalan ${ }^{3}$ voorhanden zijn ende d'jnwoonders van meergemellte Naningh met haer eijgen vaertuijgen, dat anders hun niet werdt toegestaen, affcomende, sullen gehouden blijvende aen gemelte Comp ${ }^{\mathrm{e}}$ offte ontfanger te betalen twee tangans ${ }^{4}$ voor ijder prauw, behallven de gereghtigheden haerder goederen als vooren gemellt.

\section{1.}

Js mede voorschreven jnwoonderen toegestaen, dat den gemellten ontfanger offte sijne dienaers niet sullen vermogen, de gereghtigheijt van de betele te vorderen voor dat den prijs van voorschreven blaeden in de bancksaell gemaeckt ende deselve verkofft zijn, om der luijden schade mits bederven van $\mathrm{d}^{\circ}$ bladeren voor te comen.

12.

Eenige prauwen oft baluijns ${ }^{5}$ int Pacalam van Naningh aen langhden ${ }^{6}$, sullen de eijgenaers der goederen gehouden blijven, de

1 Dagh-Register: "vertoeven".

2 Dagh-Register beter: "geenige".

3 De juiste ligging mij niet bekend.

4 Tanga's of tangen, een munt van Vóór-Indië (Vgl. Hobson-Jobson, p. 682). De O.I. C. liet zelve in 1658 en 1660 aanmaken: stuckjens getrocken cooper, (of tin) in forme als de tangen, op de cust van Indië, Seylon ende Cormandel". Vier tangen = „een gemeene stuyver" (Van der Chijs, Plakaatboek, II, bldz. 311,335$)$.

- Een roeivaartuig (Vgl. Encyclopaedie, IV, bldz. 480).

- Aenlanghende. 
voorschreven waren int huijs van den jurou paicalaen ${ }^{1}$ offte visitateur der voorschreven vaertuijgen op te leggen tot dat dragers van Naningh becomen heefft, blijvende ${ }^{2}$ voorschreven jourou paccallaen, zijnde 5 crusadus ter maendt, ten lasste van de Compe.

13.

De jnwoonders van Naningh, ellders met der woonste willende vertrecken, blijvende gehouden aen denselven ontfanger te verthoonen een schriftelijck affscheijt van den Capiteijn, met 't zegell van de Compe geteijckent, nevens een hoen tot. schenckagie voor ijder persoon ten proffijte van de Compe voornoemt.

\section{4.}

Van gelijcken ${ }^{3}$ eenige Manicabers van andere plaetsen om in voorschreven Naningh te resideren offte op te reijsen, sullen desellve als voor desen verobligeerdt zijn, aen de Generaele Oosstindische Comp $^{\mathrm{e}}$ voor ijder hoofft te betalen een $\mathrm{R}^{\mathrm{a}}$ van aghten in spetie; ende sonder consent van den ontfanger offte tomagon ende te betalen voor hoofftgellt ${ }^{4}$ als vooren vertreckende, boven dien verbeuren een amende van $10 \mathrm{Ra}$ ten behouve van de voorschreven Compe.

\section{5.}

Eenige slaven offte slavinnen uijt Naningh naer Malacca om Chrissten te werden verloopende, de ${ }^{5}$ eijgenaers van sodanige slaven offte slavinnen genieten ende goedt gedaen werden de gereghte helfft van den prijs dersellver slaven offte slavinnen, volgens den taxt bij den tommagon, fiscaell, balieu offte ontvanger daerop te stellen, sonder meer.

\section{6.}

Maer eenige lijffeijgene van de Comp offte de jngesetene van Malacca, Cristen offte Mooren, naer Naningh als omleggende plaetsen met de vlught haer begevende, sullen de voorschreven capiteijns ${ }^{6}$ offte oudsten sampt dersellver jnwoonderen, niemandt

1 Dagh-Register: njuroupancallaen." Dus: djoeroe pentjalang, m. a. w. het hoofd van het wachtschip, die de vaartuigen had te visiteeren (Vgl. Encyclopaedie, IV, bldz. 485).

2 Dagh-Register: "de tractement van."

3 Dagh-Register: "comende."

"Dagh-Register: "ende t'betaelen van hooftgelt".

${ }^{5}$ Dagh-Register: "sullen de."

"Dagh-Register: "Capiteyn."

7• Volgr. III. 
uijtgesondert, gehouden wesen, desellve persoonen vasst te houden ende op stondt naer Malacca te brengen, om aen haere meesteren geleverdt te werden, mits genietende van de voorschreven eijgenaers. 5 crusadus sonder meer.

\section{7.}

Ende opdat den jnhoudt van bovenstaende artijkell onverbreeckelijck naergecomen werden, belooven ende sweeren de voorschreven hooffden, soo voor haer sellven als in de naem van de gantsche menigte, binnen den tijt van een maendt den $\mathrm{H}^{\mathrm{r}}$ Gouverneur offte sijne gemachtigens ter handt te stellen alle verlope Christenen, slaven offte slavinnnen, soo wie die geduijrende de belegeringh der stadt als naderhandt becomen en voor lijffeijgeneaen de Manicabers vercofft zijn, sonder eenige derselver te versteken offte aghter houden, onder wadt pretext offte deckmantell 't sellve. zoude mogen wesen. 1

\section{8.}

Mits genietende tot rantsoen voor die geene, welke staende devoorschreven belegeringh becomen zijn, hunne waerde ter taxatie ende approbatie van de $\mathrm{H}^{\mathrm{r}}$ Gouverneur ende desselffs Raedt, in wiens willekeur sall staen de voorschreven lijffeijgenen door ${ }^{2}$ densellven prijs aen te vaerden offte de eijgenaars te laten behouden.

19.

Met zodanigen verstande bij alldien eenige vrije Maleice Christenen in gemelthe Naningh haer onthouden ende met de landbouw als planten van betelen erneren willen, 't sellve hem sal werden toegestaen, mits betalende de cosstume nevens andere jnwoonderen ende namentlijck dat blijcke, sulx geschiet uijt vrije wille sonder verleijding offte bedwank van jmanden.

20 .

Zoo belooven de voorschreven oversten (nomine als vooren) binnen den geprefigeerden tijt in Malacca aen de gemaghtigens van well gemellten $\mathrm{H}^{\mathrm{r}}$ gouverneur oock te leveren alle het geweer van pieken, mussquetten, degens, houwers, swaerden, jtem boosskruijdt,

1 Dagh-Register 1641-1642, bldz. 78: „Die van Naningh comporteerden haer gehoorsaem tot onsen staat, maer waren tot 't restitueren van Christenslaven en 't becomen geweer seer traagh."

2 ,Voor." 
lonten, kogels ende ammouitie van oorlogh, niets gereserveerdt offte uitgesonderdt, sonder eenige dersellver te behouden offte versteken, veelmin namaels te vercoopen, kopen offte ellders te vervoeren op verlies van lijff en goedt. 1

\section{1.}

Jn wellcke penaliteijt mede sullen vervallen ende paratelijcken werden geexecuteerdt alle die eenige Christenen, slaeff off vrij persoon, aen Mooren offt Heijden naert sluijten van dese contract vercoopt offte desellve, $t$ zij goedt willens offte met bedwanck, van haer meesters traght te onttrecken offte vervoeren, jnsonderheijdt die soodanige Christene slaven laet besnijden offte met gewellt daertoe tracht te bewegen.

\section{2.}

De voorschreveu jnwoonderen van Naningh sullen niet vermogen, met eenige buijtenlantsche natie te handelen offte trafficqueeren, directelijck offte jndirectelijck, maer blijven gehouden hare goederen eenelijcken aff te brengen langs de revier van Malacca, sonder eenige andere passagie offte frequentatie met voorschreven vremde handelaers langs de reviere Panagie ${ }^{2}$ te houden, onder wat pretext $t$ zellve mogen wesen, op verbeurte van lijff en goedt.

23.

Ende opdat den jnhoude van voorverhaellde poincten ende artijkulen in alle hare leden onverbreekelijck aghtervolght ende naergecomen werden, is met gemeen bewilligen tot hoofft ende capiteijn van gemelte Naningh met resordt van dien bij den $\mathrm{H}^{\mathrm{r}}$ Gouverneur en Raedt gestellt ende geauthoriseerdt den voorgemelten Toulela Palawan; ende radia Mera, Parpatij, Souwantan, Maranga, Mattamara ende Bansa de Raija als overstens ende raden neffens densellven Toulela Palawan, sonders welckers advijs ende goedtvinden mits ${ }^{3}$ het gouvern ${ }^{t}$ ende beleijt van Nanningh aengaende sall mogen gepitchiaerdt offte besloten werden, op pene van nulliteijt ende verlies zijns ampts, tot welcken eijnde blancke brieffken ${ }^{4}$, met merck van de Comp ${ }^{e}$ getekent

1 Vgl. hiervóór, bldz. 354, noot 1.

2 Vgl. Dagh-Register 1641-1642, bldz. 79, 94, 95, 112, 131, 137. Is deze stroom de tegenwoorpige Linggi? In elk geval ligt zij „op dese syde van Cabo Rachado" (Dagh-Register 1640-1641, 'bldz. 226).

3 Dagh-Register: "niets."

4 Dagh-Register: "de blancke brieffkens." 
door den schrijver Jntse Vader ${ }^{1}$, omme eenige commandementen offte passen te schrijven, niet sullen vermogen werden uijtgedeellt, ten zij desellve blijken van voorschreven gemeen consent.

Alldus gedaen, geresollveerdt ende gearresteerdt bij den $\mathrm{H}^{\mathrm{r}}$ Gouverneur ende zijn E. Raden, sampt den voorgemellten Toule Palawan ende oversten (dempto radia Mera) ende tot meerder verseekeringh ten wederzijden onderteekent. Actum in de stadt ende fortresse van Malacca desen $15^{\text {en }}$ Augusstij 1641. Was onderteekent Joan van Twist, Anthonij Hurdt, Geraerdt Herberts, J. Lamotius, Joan Verpoorten, Pieter Back ${ }^{2}$, Lourens Florssenburgh ${ }^{3}$, Jan Janszoon Menie, sabander; ende mij present: Adriaen Hoffcamp, Secretares.

\section{JAPAN.}

Angustus 1641. *

In Juni 1641 vond dan plaats (zie hiervóór, $\mathrm{N}^{\circ} \mathrm{CXXXV}$ ) de bekende gedwongen, maar op zichzelve niet onaangename, verhuizing der Nederlanders van Firando naar Nagasaki (Desima). De ontvangst dáár viel niet mêe. De onzen werden wel "met vriendelijeke woorden ontvangen, maer onheuselijck getracteert". Zóó werd Lemaire gedwongen, „om des

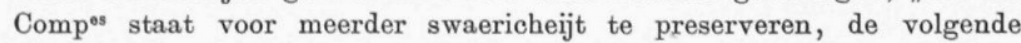
ordonnantie (tegen zijn gemoet) te onderteijckenen", terwijl nog andere "schadelijeke ordonnantien" (hieronder volgende) werden vastgesteld (Vgl. Nachod, Japan, S. 295 ff; Dagh-Register 1641-1642, bl. 68, vv.).

Wij gebieden ende gelasten den Hollandschen capp $^{\mathrm{n}}$ wel stricktelijcken, zijne onderdanen te ordonneren, soowel te lande als op de schepen varende, dat egene Christense ornamenten aen den Japanderen, Chinesen ofte eenige andere natien, die hier woonen, navigeeren ende traffiiqueren, sullen vercoopen, verruijlen nochte vereeren, mitsgaders in tegenwoordicheijt deses lants natie ende vreemdelingen eenige oeffeningen met 't voor verhaelde gespuijs bij der hand te nemen, ofte ijmant hiertoe te animeren; item dat den

1 Dagh-Register: "Intche Vadaer."

2 Vermoedelijk beter: „Baeck.”

${ }^{3}$ Schrijffout voor: Forsenburgh.

4 Overgenomen uit Dagh-Register 1641-1642, bldz. 69. De bepalingen dagteekenen van na 11 Augustus (Nachod, Japan, S. 298. Vgl. Valentijn, V, 2, Japan, bldz. 84). 
Sundagh ofte Rustdagh, van gelijcken Heijlige dagen die gewoon zijn te vieren, niet observeren mogen, maer soo lange in dit geweste zijn (om alle onheijlen voor te comen) deselve geschuwt sullen moeten werden. Dat men alle psalmboecken, testamenten, ofte eenige andere diergelijcke boucken, waermede de Christenen hun ordinarie te buijten gaan, uijt d'oogen der Japanderen sal houden, ofte soo contrarie te doen bevonden, sullck als de Portugeesen gestraft werden. $7^{\mathrm{e}}$ maen, $3^{\text {en }}$ dach; (onderstont) uijt den naem van de twee regeerende gouverneurs van Nangasacque.

Dat dit bovenstaende alle de Hollanders, die reede gearriveert zijn ende hier naer oock te verschijnen staan, hun door den Hollandsche capiteijn serieuselijcken belast werden zal, ende sulcx met zijn eijgen onderteeckeninge bevesticht, sullen ons wel laten gevallen. ${ }^{1}$

Was onderteeckent M. Le Maire.

Item tot meerder beswaeringe, dat gelijck eertijts de Portugeesen en nu de Chineezen, alle des Comp ${ }^{\text {es }}$ schepen gelijckelijck precijs den $20^{\text {en }}$ dagh van de $9^{\text {e }}$ Japanse maene (zijnde dit jaer $24^{\text {en }}$ October) sullen moeten vertrecken, en d'onvercochte coopmanschappen terugge voeren, vergunnende de laetcomende schepen vijftich dagen tijt, ende aen 't opperhooft met d'eerste ofte laetste te vertrecken.

Dat de rouwe sijde als ten tijde van de Portugeesen de pancado ${ }^{2}$ onderworpen, ende aen de 5 Keijserlijcke steden ${ }^{3}$ uijtgedeelt moste werden.

Dat geen Japanse dienaers mochten gebruijcken, maer van eijgen natie mosten laeten dienen, met bevel geen Japanse dienaers noch Firandesen op 't eijland bij d'onse mochten comen, mits deselve voor bedeckte Christenen sijn gerespecteert.

Dat alle 't geent van's Comp ${ }^{8}$ huijzen in Firando noch overigh

1 Lemaire vaardigde terstond de noodige bekendmaking aan de onder zijn gezag staande Nederlanders uit, welke aldus eindigt: "Niettegenstaande dit alles voor een Christelijck gemoet hert ende swaer valt om te observeren, soo ist dat echter, om alle swaericheijt soo veel mogelijck voor te comen, die hier over 's Comp' rijcke capitalen, schepen ende volckeren mochten comen te ontstaen, ons soo lange hier noch sijn naer sullen moeten voegen. Ondertusschen betracht een ijder met innerlijcke heijlige gedachten zijn Godt te dienen."

2 De jaarlijksche prijszetting door de gouverneurs van Nagasaki van de verschillende zijdesoorten.

3 Yedo, Miako, Osaka, Sakai en Nagasaki (Nachod, S. 244). 
was most affgebroocken werden, mitsgaders de coebaeij ${ }^{1}$ en 't vaertuijgh dat in lossen en laden onnodich was vercoopen mosten.

Dat geen goudt noch goudtwerck uijtvoeren en jaerlijex maer 50 cattij wortel nisien ${ }^{1}$, weijnich swavel en buscruijt, geen meer rijs, terwe, boontiens, en victualie als tot de reijse noodich, uijtvoeren mochten, noch geen lackwercken, schutsel $\&^{\mathrm{a}}$ daer Japanse steeden, forten off personen, insonderheijt die wapenen excerceren [op afgebeeld waren], op sware straffe.

Dat de Keijserlijcke Maijt expresselijck bevoolen hadde, de Nederlanders in alles conform de Portugeesen te tracteren, sonder daertegen ijets te mogen versoecken, en sulcx niet gesint sijnde te gedoogen, mochten gaen van daer gecomen waren: Japan soude evenwel niet gebreecken maer van dienstige waren werden versien; doch dewijle de Maijt was bericht, de Hollanders wel Christenen, maer die relegie niet voortplanten en den Portugeesen vijanden waren, stont hun lieden (hoewel daer weinich staets van maeckte) den handel in sijn landen toe. ${ }^{2}$

\section{VENGURLA-BIJAPOER. ${ }^{3}$}

\section{December 1641. 4}

Het verdrag van Maart 1607 met Bijapoer (zie hiervóór, bldz. 296) was niet tot uitvoering gekomen, en zoo weinig staat was te maken op de goede gezindheid van den Sultan tegenover de O. I. C., dat hij, die steeds dobberde tusschen de Portugeezen en ons, en zijne handen vol had met zijne pogingen tot verdere uitbreiding van zijn rijk in Oostelijke richting ten nadeele van Karnatika (Dagh-Register 1640-1641, bldz. 323 ; 1641-1642, bldz. 272), den 4 Juni 1641 zich tot een verdrag met de Portugeezen liet overhalen, zeer beslist tegen de onzen gericht (DaghRegister 1641-1642, bldz. 208, v.). Toch waren in de na 1637 verloopen

1 ?

2 "'t Effect van dese schadelijcke ordonnantiën was terstond punctueel int werck gestelt..... Aen alle welcke onredelijcke proceduuren en seer veel andere van minder importe (vgl. Valentijn, Japan, bldz. 84, v.) .... gantsch claerlijck blijkt, hoe des Comps gelegentheijt int Japanse rijek... allenxkens verslimpt, verandert en soodanich vervallen is, dat selfs veel Jappanders oordeelen, daarinne geen soulaes noch verbeteringh (ijmmers raeckende de vexatiën) te verhopen staet, 't welcke den alregerenden Godt tot 's Comp' besten dienst salichst gelieven te schicken".

s Dit opschrift ook te lezen in plaats van het foutieve "Kust van Malabaar" op bldz. 294.

4 Overgenomen uit Dagh-Register 1641-1642, bldz. 239, 240. 
jaren de betrekkingen tusschen de Nederlanders en het rijk van Bijapoer niet verbroken geworden. Zóó werd den 21 October 1640 de opperkoopman Klaas Korneliszoon Block "met een proper geschenck" naar den Sultan gezonden, om de Portugeezen, van wie men had vernomen, dat zij met Bijapoer wilden onderhandelen, „daerinne voor te comen”. Block verzocht nieuwe fermans, nl. van tolvrijheid voor 's Comp' goederen en tot verlof, om, "dewyle (vermits der Portugesen boosdadicheyt) in Wingerla Compes dienaeren ende middelen niet wel seecker waren, de logie met eenich geschut mochten versien". Niettegenstaande stellige beloften, werden de fermans wel "geconsipieert ende geschreven", maar waren zij "noch niet geteeckend ofte geschapt", toen Block na eenigen tijd toevens weder vertrok (Vgl. Dagh-Register 1640-1641, bldz. 190, v.). Niet lang daarna moeten de onderhandelingen met de Portugeezen, die tot het verdrag van Juni 1641 hebben geleid, zijn begonnen. Al spoedig echter kwam eene nieuwe wijziging in de politieke verhoudingen en aan Bloeq, die in October 1641 weder naar het Bijapoersche hof vertrok en tamelijk forsch optrad, gelukte het, onderstaande fermans te verkrijgen, „sijnde in substantie partije schoone Moorse beloften, die meer tot baetstreckinge als uijt goede meeninge voortgecomen sijn": het bleek o. a., dat de Sultan in die dagen ${ }_{n}$ andermael tracht in vruntschap met de Portugesen te comen", al gaf hij voor, dat hij „met sonderlinghe vruntschap ontsteken" was voor Blocq: „wij spreecken met de Portugesen met ons mont, maer met U met onze harte", ${ }^{1}$ enz. (Dagh-Register 16411642 , bldz. 230 , v.v., 238 , v.v.).

Fierman des conincx van Visiapour om thol vrij overal te negotieren. Hierboven stont een zegel met inct gedruckt, daerop sijn tijtel opt Parsiaens geschreven stont.

Alle gouverneurs, tonnedaers, karokas, thollenaers, ende toesienders van wegen als pachters ende anderen, hoe die oock souden mogen zijn, bevel hebbende over eenige plaetsen onder ons gebiet, werden bij desen verwittight, dat d'Hollanders ons clachtig gevallen sijnde, onse fiermans aen haer om over al thol vrij te zijn verleent ${ }^{2}$, niet geobedieert wert, wij uijt onse authoriteijt hem desen een ander tot renovatie ende becrachtinge desselfs hebben vergunt, gebieden ende belasten een ijder wie het sij, dees onse gebot te obedieren, ende soodanigh te onderhouden, dat de gemelte Hollanders niet andermael clachtigh comen te vallen, op pene die sulcx contrarieert sonder genaeden, ander ten exempel, gestraft sullen worden, sonder dat hun met d'een off d'ander excuse sullen mogen behelpen.

1 Toen in 't begin van 1642 de Portugeezen een schip van Bijapoer bemachtigden, zorgde Block, dat dit aan 't Hof werd bekend: „om uijt soodanige vonckjes een goet vier te verwecken" (Dagh-Register 1641-1642, bldz. 251; 1643-1644, bldz. 198, 228).

2 Wanneer, is mij niet bekend. 
Fierman door den coninck van Visiapour, om een sterckte in Wingurla te mogen bouwen.

Miermamet Rassa, gouverneur ende gecommitteerde over de landen van Couckan. ${ }^{1}$

Den Hollants coopman Claes Cornelissen Blocq heeft op ons versocht om haer goederen te verseeckeren, haer huijs in Wingurla met geschut te willen stercken, dat wij, mits hun vijanden daer dicht sijn, hebben vergunt. Derhalven U. l. bij desen belast wert, haer naer haer welgevallen sulx te laten doen, sonder haer eenige verhinderinge int stellen vant geschut, aen lant brengen van amonitie, te doen, maer alle hulp ende vruntschap te presteren, dat U. l. scherpelijck bevolen blijft. ${ }^{2}$

\section{MAURITIUS-MADAGASKAR.}

\section{Maart 1642, ${ }^{3}$}

Reeds op hun eersten tocht naar Indië bezochten de Nederlanders (September 1595-Februari 1596) Madagaskar (Vgl. De Jonge, Opkomst, II, bldz. 189-193, 302, v.v.). Op latere reizen werd het eiland meer dan eens aangedaan, als ververschingsplaats voor onze schepen, evenals ook Mauritius. Den 7 Mei 1638 werd laatstgenoemd eiland voor de O. I. C. in bezit genomen, óók uit vrees, dat andere Europeesche natiën er zich zouden vestigen. Van daar uit werden eveneens betrekkingen met Madagaskar gezocht: vooral slaven trachtte men op te koopen, tot welk doel eenige Nederlanders op dit eiland werden geplaatst. Op last van den gouverneur-generaal Van Diemen deed de commandeur van Mauritius, Adriaan van der Stel (1639-1645), zelf een tocht naar Madagaskar, waar ook andere Europeanen, o. a. de Franschen, betrekkingen gezocht hadden en verkregen, in 1641. Hij moest daar handel trachten te drijven en contracten sluiten. Dit gelukte hem met den "Coninck" van Antongil aan de Noordoostkust, waar eenige Nederlanders werden achtergelaten voor het onderhouden der betrekkingen (Vgl. Heeringa, Mauritius, in Indische Gids, 1895, I, bldz. 1-5, 22, v., 29, 30-31).

1 Bedoeld wordt natuurlijk Konkan, de benaming voor de kuststrook tusschen Surat en Goa (Hunter, Gazetteer, V, p. 436; vgl. hiervóór, bldz. 295).

${ }^{2}{ }_{n} \mathrm{Om}$ alle disastre die haer verleden jaer de Portugesen gedreijcht hebben voortecomen was in Raden geresolveert den $10^{\text {en }}$ Maij (1612) 't Comp ${ }^{8}$ huijs in Wingurla met 30 man en 6 lichte stucken geschuts te verstercken" (DaghRegister 1641-1642, bldz. 251. Vgl. 1643-1644, bldz. 240).

$s$ Uit het Contractboek. 
Allsoo Sijn Maijesteijt Filu Bucon ${ }^{1}$, Coninck in Antongill, $\operatorname{mitg}^{\mathrm{s}}$ de hooghgebooren Princen, Sijne Maij ${ }^{\mathrm{t}}$ gebroeders ende groote subjecten, tot diverse tijden justantelijck aen den E. Adriaen van der Stell, commandeur van wegen de Nederlandsche Oostindische Comp ${ }^{e}$, hadden versoght, omme in hun hoofftplaets Antongill op des Comp ${ }^{s}$ eijland Madagasear ${ }^{2}$ eenige Nederlanders te laten habiteeren, soo ist dat den E. commandeur voornoemt ter eener ende Sijue hoogh gemelte Maijt ter andere zijden hebben goedtgevonden, met den anderen te accordeeren dese naer volgende artijkulen.

Ten eersteu soo verclaerdt Zijn Maijt den koninck Filij Bukon, mitgaders de hooghgebooren princen ende Zijn Maij ${ }^{\text {ts }}$ broeders Afulij Bensendik, Fulij Larifon, Fulij Besieranga, Fulij Behanu, Filu Billas ende alle andere Sijne Maijts groote zubjecten, hun te wesen ware opreghte ende wettige ondersaten van d'Ed. Hooghmogende Heeren Staten Generael der Vrije Vereenighde Nederlanden, Sijn Hoogh ${ }^{\mathrm{t}}$ den prince van Orangie, mitsgaders de Nederlantse Vereenighde Oosstindische Comp ${ }^{\mathrm{e}}$, gelijck zij dan de hooghgemelte Heeren Staten Generael mitsgaders de Nederlandsche Vereenighde Oosstindische Comp ${ }^{\mathrm{e}}$ houden ende erkenuen voor hunne wettige eenige ende souveraijne overheijt.

Zullen ${ }^{3}$ dienvolgende tot allen tijden gehouden wesen, het landt van Antongill uijt den naem ende van wegen de Hoogmogende Heeren Staten Generael der Vrije Vereenighde Nederlanden ende Zijn Hoogh ${ }^{t}$ den prince van Orangie te beschermen ende verdedigen, soo well tegen jngelande vijanden ende rebellen als alle andere uijtheemse jnvasien.

Ende sullen ${ }^{4}$ niet gedoogen, dat allhier eenige Franscoijsen, Engelsen, Deenen, Portugeesen, Spangiaerden offte andere Europische natien possessie offte besettinge nemen, maer desellve bescheijdelijck affwijsen, den handell beletten ende het landt voor de meergemellte Heeren Staten te verseekeren.

Dat voortaen geen slaven, slavinnen, rijs offte andere voorvallende coopmanschappen aen ijmandt mogen vercoopen dan alleen aen de dienaers van de Nederlandtsche Compe, die daertoe sullen werden gecommitteerdt.

1 Vgl. over de titels o. a. Heeringa, t. a. p., bldz. 46.

2 Deze bewering, dat Madagaskar was een eiland der O. I. C., is in strijd met het sluiten van dit contract zelf.

3 Nl. de Nederlanders?

- Nl. de "coningh" van Antongil en de zijnen. 
Ende soo voortaen, gelijck voor desen is geschiet, niemant vermogen eenige slaven offte slavinnen naer d'ander zijde vant landt te voeren om alldaer tegen koebeessten offte kleeden om te zetten, maer sullen selffs gehouden wesen quantiteijt vee aen te teelen om dat ${ }^{1}$ in geen gebreck comen te vervallen ende dieshallven genoodtdruckt zouden zijn, hun voedtsell ellders te soeken.

Ende beloofft den Commandeur, allhier eenige Nederlanders te laten resideeren ende hun met quantiteijt en goede sorteringe van cleeden ende andere coopmanschappen tot opcoopen van slaven, rijs en andere profitable mineralen ${ }^{2}$, die hier namaells ondeckt moghten werden, versien.

Dies sall den Coninck de residerende Nederlanders alle vriendtschap ende behulp moeten beweijsen ende hun tegen alle gewellt en overlasst van de jnwoonders beschermen, opdat met het verschijnen der scheepen geen redeu hebben, hun van quadt tractement te beclagen.

Ende sullen alle slaven ende slavinnen, die naer des Commandeurs vertreck aen de $C_{o m p}{ }^{\text {es }}$ dienaers werden verhandellt, op 't eijlandt Nosbee $^{3}$ tot des Conincks risico ende gevaer moeten bewaerdt werden ter tijt een offte meer Comp ${ }^{8}$ scheepen in de baij comen te verscheijnen om desellve te vervoeren.

Welcke bovenstaende artijculen wij ondergeschreven beloven in alle deesen ende ten vollen nae te comen. In waeraghtige verbindingh ende teijken der waerheijt hebben partijen wedersijts onse eijgen handtteijkens hier onder gestellt.

Gedaen int Nederlandts comptoir Antongill, den aghsten dagh Martij $\mathrm{A}^{\circ}$ een duijsent ses hondert twee en veertigh. Was geteeckent:

dit is het merck van filu Bukon,

dit is het merck van filu Befenedick, Adriaen van der Stell, dit is het merck van filu Laribou,

dit is het merk van filu Ballas.

Lager stondt: ons present, Joan van Beijlen ende Jacob Jacobszoon. ${ }^{4}$

1 Opdat.

2 Men hoopte o. a. op goud.

3 Nossi Bé aan de Noord-Westkust of Nossi Vé aan de Oostkust.

4 De opvolger van Van der Stel als commandeur van Mauritius, Jacob van der Meersch (1645-1648), achtte dergelijke contracten "van weinig waarde, omdat de lieden niet wisten wat ze onderteekend hadden", maar ze konden "misschien van dienst wezen tegenover andere Europeesche natiën" (Heeringa, bldz. 45). 


\section{KUST VAN KOROMANDEL.}

\section{April 1642. 1}

Matthijs Hendrikszoon Quast, bevelhebber der vloot op de Westkust van Vóór-Indië (vgl. hiervóór, bldz. 343, noot 2), overleed den 5-6 October 1641 aan zijn vóór den vijand bekomen wonden. Hij werd opgevolgd door Cornelis Leendertsen Blauw, die den 5 Januari 1642 met een deel zijner vloot „van voor Goas bhare” opbrak naar Ceilon en vandaar, vereenigd met Dominicus Bouwens , naar Vóór-Indië's Oostkust ging , met een troepenmacht van ruim 700 man en een vloot van 8 schepen, „om ijets voorderlijck ten dienste van de Comp op Negepatnam ende St. Thome te attenteeren", in welke beide plaatsen de Portugeezen waren gevestigd. Den 12 April kwam men dan vóór Negapatam, gelegen in het gebied van den naïk van Tanjore. Vóórdat de stad werd aangetast, begon de Portugeesche bevolking te onderhandelen en den 13 April werd "tusschen ons ende de alsdoen present wesende Portugeesen uijt den naeme van de Negapatnamse borgerije het contract getroffen", hieronder afgedrukt (Dagh-Register 1641-1642, bldz. 222, 242, 246, 252, v., $255-257,275-284,290-294,296$, v.). St. Thome werd door de onzen ongemoeid gelaten bij deze gelegenheid.

Wij Cornelis Leendersen Blauw ende Dominicus Bouwens, commandeurs ovier de vlote van offence, grasserende langhs de cust van Indie, mitsgaders deselve secrete raetspersonen, beloven bij desen van wegen Haer Ho. Mo. de Heren Staten Generael der Vereenigde Nederlanden, Sijn Hoogheijt den doorluchtige Here Fredrick Hendrick bij der gratie Gods prins van Orangien, grave van Nassauw etc., mitsgaders de E. Heren bewinthebberen van de Oostindische Compe, uijt de naeme van haer Ed. d'Heer Gouverneur Generael Anthonio van Diemen ende de $\mathrm{H}^{\mathrm{ren}}$ Raden van India, aen alle de Portugesen inwoonders der stad Negapatam, ten aensien ons desselfs residentie plaetse voornoemt demoedigh ende reverentelijck hebben opgedragen, orn 't selve met Nederlantse guarnisoen te besetten ende naer ons te nemen onder soodanige reserve dat sijlieden haere vrouwen, kinderen ofte middelen in 't minste door onse ofte d'onse niet beschadicht, maer wel ter contrarie van alle overlast der swarten ende inhabitanten deses lants bevrijt en beschermt sullen werden, blijvende sijlieden verders onderworpen, een behoorlijcke ende gereguleert contract volgens ${ }^{2}$ de buijt van de overwinnaers als andersins met ons

1 Overgenomen uit Dagh-Register 1641-1642, bldz. 256, 283.

2Op bldz. 283 : "wegen". 
aen te gaen ${ }^{\mathbf{1}}$. Tot confirmatie vant gene voorgeschreven, hebben hier ons gewoonlijck hantteijckeningh onder geset ende was getekent Cornelis Leendertsen Blaeuw, Dominicus Bouwens, Pieter Sijbrantsen Groes, Pieter Paets, Cornelis de Potter, Willem Gerritsen, Marten Gerritsen Vries, Adriaen Aldertsen.

\section{MALAKA.}

11 Juli 1642. ${ }^{2}$

Na de verovering van Malaka door de O. I. C. (vgl. hiervóór, bldz. $345,349)$ met steun van Djohor, maakte dit rijk gebruik van de tusschenkomst der Nederlanders, om een einde te maken aan den langdurigen oorlogstoestand tusschen Atjeh en Djohor. Dit denkbeeld werd in Atjeh gunstig opgenomen en de vrede werd gesloten. Als indirect gevolg hiervan trok Atjeh zich terug van het Maleische Schiereiland (vgl. hiervóór bldz. 345), behalve van Perak (aan de Westkust). Hier ontmoetten de Compagnie en Atjeh elkaar weder. Perak toch vormde met de onder Siams min of meer nominale opperhoogheid staande rijkjes Kedah,

1 Dit gebeurde den 18 April, nadat den $13^{\text {den }}$ onze troepen waren geland en "rondom de marckt gelogeert". De Portugeezen zouden nl. (volgens de lezing onzer commandeurs, die niet overeenkwam met de lezing der Portugeezen) "voor de plunderinghe" opbrengen 50000 realen, nl. 10000 terstond, terwijl „de resterende soude blijven staen, daervoor twe suffisante personen in handen te stellen", die weder in vrijheid zouden worden gesteld, wanneer het zou blijken, dat de vrede ,tusschen de Portugesen ende Nederlanders in Orienten" gesloten was (Portugal had zich in 1640 van Spanje afgescheiden) vóór den datum der overeenkomst, terwijl zij anders in gijzeling zouden blijven tot de resteerende 40000 realen waren uitbetaald. De tien duizend werden betaald, maar den $21^{\text {sten }}$ „hebben die van de stat seer onbeschaemlijeke 't selve voor desen (trouwens door hen anders opgevatte) gecontracteerde genegeert", waarna de "ostagiers" in handen der Nederlanders bleven (Vgl. nog Dagh-Register 1643-1644, bldz. 252). De veranderde houding der Portugeezen zal wel grootendeels zijn te wijten aan het verlaten (den $19^{\text {den }}$ van de stad door onze troepen. De naïk van Tanjore had nl. aan de

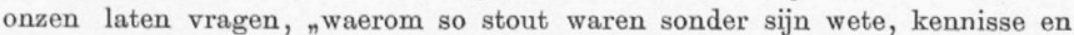
licentie in desselfs land quamen". En het antwoord, dat wij slechts den Portugeezen afbreuk trachtten te doen en „anders niet als gunst ende faveur om met hem in vrientschap te leven" zochten, had den Naïk blijkbaar niet bevredigd. Althans de onzen trokken nog in dezelfde maand uit Negapatam terug, aangevallen door "des neijoks volck" en "vresende voor meerder macht vant rijek" (Danvers, Report, p. 45, f, geeft een andere lezing, nl. dat wij vertrokken uit vrees voor de Portugeesche vloot. Hij stelt geheel deze gebeurtenis foutief in 1643); en vertrokken, " sulex de negotie tot nader gelegentheijt in des neijex 'lant geschort bleeff".

${ }^{2}$ Uit het Contractboek. 
Oedjong-Salang en Bangeri de z.g. „tinquartieren" van het Schiereiland en tin was toen een belangrijk uitvoerartikel naar Vóór-Indië en Perzië : voor de O. I. C. wel het belangrijkste van geheel het Schiereiland. Hare bestuurders wenschten daarom dien tinhandel zooveel mogelijk aan de Compagnie te trekken. Het eerst gelukten de plannen - althans gedeeltelzk - met Kedah (Vgl. Heeres, Bouwstoffen, III, bldz. VII-XI, 106 v. v., waar het contract door mij is afgedrukt geworden.)

Accoordt ende contract gemaeckt bij Jan Hermansen, oppercoopman ende directeur deser quartiersche comptoiren ${ }^{1}$ wegens den standt der Vereenighde Nederlandsche Oostindische Comp ${ }^{\mathrm{e}}$ int coninckrijck van Queda, uijt authoriteijt van d'E. Heer Anthonio van Diemen, gouverneur generael over Orienten, mitsgaders bij missive van de E. Heer Joan van Twist, gouverneur en directeur van de stadt ende fortresse Malacea en zijn E. missive aen de Maijt in dato $18^{\mathrm{e}} \mathrm{Junij}^{\circ} 1642$ ons daertoe geauthoriseerdt, ter ener zijde ende den doorlughtigen coninck van Queda, Poule Laea ${ }^{2}$ ende meer andere heerlijckheden ter andere zijde, dat voor eeuwigh onverbreekelijck, desen $11^{\text {en }}$ Julij 1642 jn Queda.

Eerstelijck sall den Koninck toelaten, [dat van] alle den tin in Queda off van buijten in comt, vallt aen de Vereenighde Nederlantsche Oosstindische Comp ${ }^{\mathrm{e}}$, de dienaers desselffs, de gereghte helfft ende dat tot 7 taijll 13 maes trae (?), jder teijll gereekent tegens $4 R^{a}$, d'masen $\frac{1}{4} d^{0}$, soude zijn gemellte taijlls en masen t'samen gerekent just $31_{\frac{1}{4}} \mathrm{R}^{\mathrm{a}}$ sleghte Quedase munt $\mathrm{p}^{\mathrm{r}}$ baer. Edogh t volck van die den thin aen de Hollanders te merckt brengen wert in haer believen vasst gestellt off kleden jegens een redelijcke marct dan gemelte Quedase munt begeeren, zonder andere uijtwegen van Spaense $\mathrm{R}^{\mathrm{a}}$ off eenige andere pretentie te maeken gehouden zijn te leveren.

Vorders den Coninck sall niet vermogen, eenigh tin met zijn eijgen jaghten, prauwen als andersints, veell min andere natiens, uijt te voeren voor ende alleer den Coopman offte andere Comp ${ }^{e}$ dienaers, daer toe gelasst, met een gecommitteerde van den Coninck aen boordt gecomen zijn, jtem de quantiteijt gewoogen en perfectelijck aen de voorstadt Ponpon opgenomen heefft; welck verbandt gemelte Comps schepen off jaghten als anders, eer eenigh tin van

1 Vgl. Dagh-Register 1640-1641, bldz. 167.

2 Poelau Laddas (ten Noord-Westen van Kedah)? 
hier vervoeren, gelijcker wijs sullen onderworpen zijn. Die hier toe vorengenomineerde gecommitteerdens sullen zoo haest de jaghten, scheepen off prauwen affgedreven ende zijlieden boven gecomen zijn, nae den Koninck off Orangcaija Basaer ${ }^{1}$ ter eerster gelegentheijt jder met hun brieffgen transporteeren, allvooren besonder een contrabouck van uijtgevoerde continueel t samen well houden. Jtem de qualiteijt vau 't uitgevoerde aan den Koninck off Orancaija vertoonen. Soo dan bevonden werdt, meer door den Koninck off s'Konings bevell als andersints dan de Hollanders uijtgevoerdt offte toegewogen hebben, sall den Koninck gehoudeu zijn, binnen 5 a 6 dagen voor soo veell in ons packhuijsen offt allreede wegh gesondene minder bevinden voor de prijs ende conditie hier vooren beraemdt te sullen leveren.

Den Coninck zall vermogen wat schepen uijt Beugale, Suratte als indere plaetsen, so passen van de opperhooffden der Nederlandtsche $\mathrm{Comp}^{\mathrm{e}}$ dienaers uit die quartieren vertoonen, maer anders niet, om in Queda te handelen vergunt werden. Edogh zoo hun passen op Malacca eerst aen te doen houden ${ }^{2}$ ende daer nogh niet, maer eerst aencomen, sall in dier gelegentheijt den coopman van de Nederlanse Compe met een gecommitteerde van de Coninck uijt last der gemelte coninck ende d'Ed. Heer Gouverneur Generael de revier ontseght werden ende nae Malacca wijzen; pas van de Gouverneur aldaer op hun wedercomste vertoond hebbende, den handel, ook anders niet, vergunnen, tot welk visiteren der passen den coopman van meer aengetogen $\mathrm{Comp}^{\mathrm{e}}$ gelooff zall gegeven werden. Was onderteekent Joan Hermansen. Ter zijde stondt : na gedaene collatie jegens d'origineele, door den Koninck int Maleijts heefft laten schrijven ende met sijn gewoonlijcke merck bevestight, is dese daermede bevonden te accordeeren, datum ut supra. Was onderteekent Joan Hermansen.

\section{AMBON.}

20 Augustus $1642{ }^{3}$.

Zooals reeds gezegd is (hiervóór, bldz. 335), was ook na Van Diemen's tweede bezoek aan Ambon de rust niet hersteld. Kakiali, de kimelaha

${ }^{1}$ Hier blijkbaar een titel, aan een bepaald ambt verbonden.

2 M. a. w. : zoo hunne passen inhouden, dat zij eerst Malaka moeten aandoen.

3 Overgenomen uit Dagh-Register 1641-1642, bldz. 22. 
Loehoe en de Ternataansche Grooten wenschten zich niet in de omstandigheden te schikken. Vooral de kimelaha Loehoe trad op den voorgrond in het verzet tegen de onzen, gesteund o. a. door Makassaren. Nadat in 1641 de krijg met afwisselend geluk was gevoerd, kreeg in Februari 1642 de bekwame gouverneur der Molukken, Antonio Caen, de leiding. De Kimelaha trachtte met de onzen weder op goeden voet te komen en verzocht met zijne „adherenten" om vrede, nop sodanige goede conditien ende voorwaerden" als Caen "soude gelieven te prescriberen, ende wierd

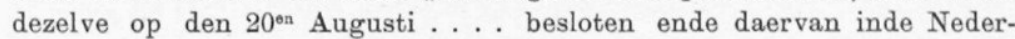
duijtse als Maleijtse tale een contract getekent, luijdende int Nederduijts van woort tot woort als volgt." (Vgl. Tiele-Heeres, Bouwstoffen, II, bldz. LXIV, v.; deel III, bldz. XXVI, v., 40; Dagh-Register 1641-1642; bldz. 1-22.)

De gecommitteerde afgesanten der negrijen Combello, Masselijn ${ }^{1}$, Erangh, Noula ${ }^{1}$, 't eijlant Quelangh, Hattapouti ${ }^{1}$, Assahoudi, ende Latou Tahakeca ${ }^{2}$, binnnen 't Casteel de bevredingh ende slissing van oorlogh bij d'E. $\mathrm{H}^{\mathrm{r}}$ gouverneur Antonio Caen versocht hebbende, sijn alle hun alle vorige contracten, insonderheijt het laetste in den jare 1638 tusschen d'Ed. Heer Gouverneur Generaal Antonio van Diemen ende d'E. $\mathrm{H}^{\text {ren }}$ Raden van India ten eenre ende den Coninck van Ternate ter anderen zijde besloten ${ }^{3}$, voorgehouden, waerop naer verscheijde vriendelijcke discoursen (alsoo verclaren gemachtigt te sijn om alles af te handelen) gevolght is, dat belooft hebben het voorgaende contract naer te comen ende op haer wetbouck Mussahaphi gesworen, ons metten aldereersten, soo haest sijn E. selfs ofte een commissaris uijt sijn E. name voor Combelle comt te verschijnen, bequame plaetse naer onse gelieven tot huijs ende sterck gebouw willen inruijmen ${ }^{4}$, de vremdelingen wegh schaffen, den handel verbieden, deselve nimmer meer aanhouden, den Quimelaha ende sijnen aeuhanck verwerpen 5, alle haer geschut ende oorlogsgereedschap, dat noch in de bovenste negrijen is leggende, beneden in onse bewaringe brengen ende wijders alle de giroffelnagelen, die in toecomende tijden te innen staen, in des Compes magasijnen, mits betalende den bestelden prijs sullen gebracht worden, waertegens de $\mathrm{E} . \mathrm{H}^{\mathrm{r}}$ gouverneur voornoemt is belovende, dat henluijden voor allen overlast, dien de vijanden der Ternataensen ende Nederlantsen staet

1 Massili aan de Oostkust van Klein-Ceram; Noela aan de Westkust, Hatapoeteh op Kelang.

2 Vgl. Heeres, Bouwstoffen, III, bldz. 40, noot.

3 Vgl. hiervóór, bldz. 316, v. v.

4 Dit gebeurde reeds den 25 Augustus (Dagh-Register, bldz. 22, v.).

5 Caen vertrouwde den Kimelaha volstrekt niet (Vgl. Bouwstoffen, III, bldz. 40 , noot). 
souden mogen int werck stellen, wil beschutten, ende wijders versorgen dat in alle haer gerechticheijt voorgestaen werden.

Gedaen int casteel, Victoria den $20^{\text {en }}$ Augusti $A^{\circ} 1642$ na de geboorte Jesu Christi ende was onderteijkent Majjnene, lebe Hatulessi, sabandar, orangcaijs van Combello, Tatualat, orangcaij van Erang; Seli, patij van Quelangh, Cacịjali, passe(?) van Hattapouti; Vailehu van Noula; Tamaella, omoen(?) van Assahoudi; Latoutahakeca ${ }^{1}$.

\section{FORMOSA.}

\section{Angustus 1642. ${ }^{2}$}

Aan Formosa's Noordkust waren nog steeds de Spanjaarden gevestigd gebleven op Kelang, waar zij zich, in 1626 vermoedelijk, hadden neergezet (Vgl. hiervóór, bldz. 239, noot 1). In 1642 werd een ernstige aanval op deze vijandelijke stelling in Oost-Azië voorbereid door de Nederlandsche autoriteiten, nadat versehillende verkenningstochten hadden plaats gegrepen, o. a. in 1641 onder leiding van Johan van Linga. Terwijl de Hooge Regeering den 26 Augustus 1642 „den sergeant mayor ${ }^{3}$ Johannes Lamotius" naar Formosa zond, als "veltoverste over 's Compies chrijehsmacht" en om "door Godes hulpe de Castiliaense forten van Quelang te conquesteren, de geruchte goutmijnen te ondecken en de rebelle als tot noch ongehoorsaame inwoonderen tot ruste van dat eijlandt onder subjectie te reduceren", had de toenmalige gouverneur van Formosa, Paulus Traudenius (1640-1643), reeds op eigener autoriteit gehandeld. Toen in 't begin Augustus 1642 nog geen schepen en troepen uit Batavia waren verschenen, zond hij den kapitein Hendrik Harousé den 17 dier maand naar Kelang met "een redoutable macht" van 5 schepen en 3 scheepjes met een 400 militairen, enz. Den $21^{\text {sten }}$ kwamen de onzen bij het eiland Kelang. Het „roijale fort" werd den $26^{\text {sten }}$ aan de onzen overgegeven na korten strijd, waarbij 't soms "wat heet van den rooster" ging. Acht-en-dertig stukken geschut werden buit gemaakt (Vgl. Dagh-

1 Bij Valentijn, II (Ambon), B, bldz. 133, staan niet geheel dezelfde namen. Trouwens beide lezingen behelzen verschillende fouten. Gehéél duidelijk waren zij mij niet.

2 Uit het Contractboek.

3 Deze rang had toen een geheel andere beteekenis dan tegenwoordig: een sergeant-majoor was toen een hoofdofficier (Vgl. o. a. deze Bijdragen, Nieuwe reeks, $I$, bldz. 97 jo 96 , waaauit blijkt, dat een kapitein wordt bevorderd tot majoor of sergeant-majoor). Lamotius had zich in 1641 bij de verovering van Malaka verdienstelijk gemaakt. Deze Hagenaar (en niet Kaartekoe) is de eigenlijke man van de verovering (Vgl. Heeres, Bouwstoffen, III, bldz. V). 
Register 1641-1642, bldz. 56, 59, v., 111, 152, 167; P. A. Leupe in deze Bijdragen, Nieuwe Volgreeks, II, bldz. 72, v.v., waar óók de artikelen van overgave zijn afgedrukt). Toen Lamotius in het begin van September op Formosa kwam, werd hij door Traudenius dadelijk naar Kelang gezonden, maar de verovering had reeds plaats gevonden ( $\mathrm{Vgl}$. hierachter, No CXLVIII).

Artijkulen, beslooten ende geaccordeert tusschen den E. Manhafften capitein commandeur Henrick Harouse ende zijnen Raedt, wegens d'Edele $\mathrm{H}^{\text {ren }}$ Staten Generael, Zijn Princelijcke Ex ${ }^{\text {tie }}$ Fredrick Hendrick ende d'E. $\mathrm{H}^{\mathrm{n}}$ Bewinthebberen der Vereenighde Nederlandtsche Oostindische Comp ${ }^{e}$ ter eenre ende Gonsalo Portillo, gouverneur wegens zijn Conincklijcke Maijt van Spanjen over de fortressen op Quelangh ter andere zijde, op het overgaen ende uijtrecken derzellver desen $26^{\mathrm{e}}$ Augustus $\mathrm{A}^{\circ} 1642$.

Eerstelijck dat den Gouverneur met alle zijne solldaten ${ }^{1}$ uit het fordt sullen trecken in volle geweer tot Cloosster ${ }^{2}$ toe sonder verder, en het sellvige alldaer nederleggen.

Ten tweeden dat zijluijden niet meer als een a twee packen cleeren sullen aentrecken sonder meer.

Ten darden dat de geesstelijcke persoonen ook sullen uijttrecken met hare kleederen zonder jets meer.

Ten vierden dat zijluijden int Cloosster niet ${ }^{3}$ sullen logeeren tot naerder ordre.

Ten vijffden ende ten laetsten dat zijluijden naer Taijovan sullen versonden werden ende tot naerder ordre van onse hooge overheden alldaer zullen blijven, $t$ zij dan dat den $\mathrm{H}^{\mathrm{r}}$ gouvern ${ }^{\mathrm{r}}$ generael Anthonio van Diemen, residerende tot Batavia, haer will largeren sonder rantsoen offte niet ${ }^{4}$. Onderstondt. Hendrick Harouse, Joan

1 In 't geheel waren er op het fort 446 zielen, vrouwen meegeteld, waaronder 115 Spanjaarden. Zij werden naar Batavia gezonden en gingen deels naar Europa, deels naar Manila via Makassar. De gouverneur Portillo ging voorloopig naar Vóór-Indië, „beducht sijnde in Manilha comende sijn hooft te verliesen". De verovering van Kelang werd door de onzen zeer hoog geschat: „sulcx dat nu door Godes genade meester van geheel Formosa sijn."

2 Het klooster St. Domingo op het eiland.

$s$ Deze ontkenning staat niet in de lezing in de Bijdragen, vermoedelijk terecht.

4 Zie hiervóór, noot 1.

7• Volgr. III. 
van Linga, Pieter Baeck, Dirck Janszoon Boll, Pieter Boon, Bastiaen Bardoell, Joannes Burgers, Thomas Pedell, Barent Janszoon ${ }^{1}$ en Pieter Heịn, Secretaris.

\section{PERZIË.}

October 1642. 2

Onderstaande documenten zijn slechts bekrachtigingen der in 1623 door de Nederlanders van sjah Abbas den Groote verkregen voorrechten (vgl. hiervóór, bldz. 183-191) door zijne opvolgers. Dat niettegenstaande de bevestiging der privileges de verhouding tusschen de Perzische autoriteiten en de vertegenwoordigers der O. I. C. niet altijd rooskleurig is geweest in de dagen nà sjah Abbas den Groote (vgl. hiervóór, bldz. 246, v.v., 254, v.v., 261, v.), blijkt duidelijk uit de rapporten uit Perzië naar Batavia opgezonden (Vgl. Dagh-Register 1636-1642, passim, o. a. de behandeling, onzen "president" in Perzië, Wollebrandt Geleijnsen de Jongh, den 10 December 1641 te Gamron aangedaan, volgens het medegedeelde in Dagh-Register 1641-1642, bldz. 198). Daar dit alles echter niet noodig is voor de verklaring van onderstaande stukken, is het voldoende, dat hier slechts de aandacht daarop wordt gevestigd, zonder meer.

$\mathrm{Na}$ den dood van sjah Sofi (1628-1642) en het optreden van diens zoon Abbas II verkregen de Nederlanders, die onder leiding van den opperkoopman Hendrik van Thuijnen hem waren komen begroeten, de vernieuwing der vroegere „vrijheeden" (Dagh-Register 1643-1644, bldz. 174, v.).

Tranlaet uit het Persiaens.

Versoeckarticulen van d'E. Huijberts Visnicht ${ }^{3}$, gewesene opperhoofd wegens de Nederlantsche Compagnie over desselfs negotie en verderen ommeslagh in 't rijck van Persien, aen den Coninck Abbaas de groote in den jaere 1623 overgelevert nevens dier Maj ${ }^{\text {ts }}$ appostillen en besluijten op ijder, door de coningen Safie d'eerste en Abbaas de tweede in de jaren 1629 en 1642 vernieuwt, luijdende uijt de Persiaense in onse tale aldus ${ }^{4}$.

1 Dezelfde als Barent Culenburch (Bijdragen, t. a. p., bldz. 81)? - Genoemde officieren vormden den Raad der vloot.

2 Uit Contractboek Amsterdam III.

Den 21 October 1642 zijn de stukken, waarbij de sjah van Perzië de vroegere "mandamenten" vernieuwde, aan de onzen ter hand gesteld (DaghRegister 1643-1644, bldz. 176).

3 Zie hiervóór, bldz. 183, v.

" Ofschoon de hoofdinhoud natuurlijk gelijk is aan het "translaet", opgenomen hiervóór, bldz. 186, v.v., heb ik gemeend, óók om de grootere uitgebreidheid en sommige niet onbelangrijke verschillen, de "articulen" nog eens weer in onderstaanden vorm hier te mogen opnemen. 


\section{HET HOOFT.}

Een nootsakelijck versoeckschrift van den waren oprechten Huibert, Capiteijn der Hollanderen.

De versoecken die de dienaers van onse princen en Heeren op den Hoogaensienlijcken prince begeren (bestaen in de volgende als: ${ }^{1}$ )

\section{AR'TICUL 1.}

Eerstelijck, dat dien Hoogh aensienelijcke prince, aengaende de natie van Hollandt gebiedende, licentiere, deselve ter aller plaetse, daer se begeren, te gaen end' (aldaer) coop en vercoop te doen, sonder dat iemandt aen den staet van die natie eenige molestien toebrenge: sijn bevel is 't hoogste.

\section{'S CONINCX APOSTIL.}

Wij hebben, soodanigh ordonnerende, bevolen als sij versocht hebben. ${ }^{2}$

\section{ARTICUL 2.}

Oock soo versoeckt eerbiedichlijck, dat een mandament van rechtveerdicheijt gunstelijck gelieve te verleenen, van dat de bewaerders der groote wegen van het onderhorigh landt, wegens de rahdarije en andere gerechtigheden niet een dienaer ${ }^{3}$ en mogen nemen, als mede dat de regenten en daroegas van de gesegende rijcken 4 aen haer staet geen moeilickheden toe en brengen, nochte hare lading goederen (?) en openen, voor dat in hare woonplaetsen aengenomen sijn: sijn bevel is 't hoogste.

\section{'s CONINCX APOSTIL.}

Wij hebben ordonnerende bevolen, dat de rahdaers van de gesegende rijcken de rahdarije van de goederen, die de Hollantsche natie in de gesegende rijcken op en aff voerende sij, conform

1 In nog een ander onvolledig exemplaar in Contractboek Amsterdam III komt nog het volgende voor: "Dit volgende mandeert den Coninck Chia Abbas aen alle sijne grooten: Alle dese volgende vijftien articulen sijn met considerabel antwoort van Sijn Coninklijcke Majesteijt versiert; sult niet verwerpen, in allen van woorde tot woorde naer te comen en de sorge van dien op U nemen en effect doen sorteren".

2 Hier achter volgde: „Wit. Hier dicht aen op de laeste letters de plaets van het segel des Diwaans van den coninck Abbaes de Groote". Hetzelfde is geplaatst achter de andere artikelen. Diwan hier =eerste minister, kanselier (Vgl. hiervóór, bldz. 269, noot 7; Hobson-Jobson, p. 228 ff)?

3 Kleine Perzische rekenmunt.

4 Hiermede worden zeker ook bedoeld de onderhoorigheden van Perzië, als Hormus, Gamron (Vgl. hiervóór, bldz. 185). 
het reglement van het hooge Hoff van haer nemen, sonder een dienaar daerboven te vorderen off eischen en erkenne dit voor een saecke van gehoudenisse, en niemant van d'omeraes, ${ }^{1}$ regenten en daroegas van de rijcken en opene hare packen en kisten buijten haer believen, nochte en hengele (?) daerom.

\section{ARTICUL 3.}

Voorts soo versoeckt eerbiedichlijk dat niemant de ladingh goederen, die de Hollantse natie uijt haer eijgen landt aenbrengende sijn, het sij comptanten off coopmanschappen, in de wegh sonder reden opene en dat de raahdaars en daroegas op de goederen, diese wederom terugh affvoeren, geenige pretentie off pretext voor en nemen ende toelaten, dat se met vrede na haer (gedestineerde) woonplaetse gaen: sijn bevel is 't hoogste.

\section{'s CONINCX APOSTIL.}

Wij hebben ordonnerende bevolen, dat niemandt de ladingh goederen, die de Hollandsche natie in de gesegende rijcken aenbrengende sijn, sonder haer believen en opene en niemandt van d'omeraes, regenten, daroegas en rahdaars en hengele om de goederen die sij (Hollanderen) uijt de gesegende rijcken voeren, uijtgeseijt degene die sonder consent uijt de gesegende rijcken voeren verboden hebben.

Articul 4.

Item soo versoeckt eerbiedelijck, dat de makelaers en andere buijten de makelaers omtrent de coopmanschappen, dewelke dese natie in het hoogh aensienlijck landt aenbrengende zij, geen onrecht en plegen noch (daervan) meerder nemen mogen als haer toecomt; alsmede dat in den coop ende vercoop geen wigh en mate toe en late, die te swaer en te groot ofte te licht en te kleijn, doende haer handel met soodanige kapoan en gel (?) ${ }^{2}$, als den hoogh aenzienelijcke prince geordonneert heeft, gelijck oock dat het bazaars en gemeene volk geen buijtenredenheit en plegen : sijn bevel is 't hoogste.

\section{'s CoNINCX APOSTIL}

Wij hebben soodanigh ordonneerende bevolen als sij versocht hebben.

${ }^{1}$ Omrah $=$ hooge ambtenaren (Hobson-Jobson, p. 486). In Perzië volgens een aanteekening in Contractboek Amsterdam III "principalijek de leden van s'Coninx raedt", dus hier die gouverneurs van de gewesten, enz., welke tevens lid van dien raad waren.

2 ? 
Articul 5.

Nogh versoeckt eerbiedelijck, dat wanneer iemant van de Hollantse natie in het onderhoorige landt overlijde, de regenten van dat lantschap dan hare goederen in bewaringe nemen en houden op dat (daervan) niets verlooren en ga, totertijt een erfgenaem der overledene te voorschijn komen en ingevalle den overledene eenigh metgesel van sijn eijgen landt bij zich hebbe, dat dan die goederen aen hem (metgesel) ter handtstellen; dogh soo dit een metgesel van een ander (land) ware, dat die regenten alsvooren die goederen in bewaringh nemen en houden : sijn bevel is 't hoogste.

's ConinCX apostiL.

Wij hebben soodanigh ordonnerende bevoolen als sij versocht hebben.

AR'Ticul 6.

Ook soo versoeck eerbiedelijck, dat gebiedende bevele, dat soo wanneer int reijsen van voorschreven natie door het onderhoorige landt van den hooghaensienelijcke prince hare goederen door dieven gestoolen werden, deselve dan (wederom) te voorschijn doen brengen off anders te vergoeden hebben, als mede dat het volk van de opsienders der caffilachs (maer alleen) haer gerechtigheijt volgens de costume te nemen hebben, sonder daerboven iets te vorderen off t'eischen : sijn bevel is 't hoogste.

\section{s' CoNINCX APOSTIL.}

Zij effectueren in soodaniger voegen als sij (Hollanders) versocht hebben en erkennen dit voor een saecke van gehoudenisse.

\section{ARtTicul 7.}

Item soo versoeckt eerbiedighlijck, dat soo wanneer voorschreven natie camelen en andere lastbeesten sal begeren, de vrachtiers dan van dat landt deselve voor haer op te soecken hebben, als mede dat se, soo het van noode mocht wesen, iemant van mansel tot mansel ${ }^{1}$ (om de cafilach te geleiden) medegeven; als oock, dat de geestelijcke regenten uijt eenige intentie en interest aen haer geen moeijelijckheden toe en brengen : sijn bevel is 't hoogste.

\section{s' ConincX BesLuiJt.}

Zij effectueren in soodanigen voegen, als sij Hollanderen versocht hebben, sonder tegens het gebodene eenige contraventie te practiseren.

1 "Masel ofte rustplaetse" (Dagh-Register 1643-1644, bldz. 170). 


\section{Articul 8.}

Nogh soo versoeck eerbiedelijck, dat gebiedende bevele, dat niemandt in het huijs van voorschreven natie sonder reden en ga en ingevalle eenige in haer woningh verscheenen, en d'aldaer eenich misslagh quam voor te vallen, dat dan de regenten aen haer Hollanderen (daerover) geen travailles nochte molestien toe te brengen hebben, alsmede dat die natie haer godsdienst nae haer gebruijck in haer huijsingh ${ }^{1}$ mach oeffenen sonder dat iemant aen haer eenige moeielijckheid daer in toebrenge: sijn bevel is 't hoogste.

\section{'s CONINCX APOSTIL.}

Wij hebben ordonnerende bevolen dat in soodanige voege als sij (Hollanders) versocht hebben effectueren, sonder daer tegens eenige contraventie te practiseren.

\section{ARTICUL 9.}

Oock soo versoeck eerbiedelijck, dat soo wanneer iemandt van de Hollandse natie gevangen geraeckt geweest sijnde, (daernae) in handen van de Muslimaans en andere mochten comen te vervallen, en dat dieselve (Hollandse) natie die begeerden te coopen, niemandt dan haer (daerin) verhindere ende soo ous volk mochte begeren Muslimaan te werden dat se sonder ons ${ }^{2}$ believen geen Muslimaan en moogen werden, ende dat soo wanneer naer weijgering van onse licentie daertoe wij denselve naer ons eijgen landt versenden willen, sij (ons hierinne) dan niet en verhinderen: sijn bevel is 't hoogste.

\section{s' Conincx APOS'TIL.}

Wij hebben ordonnerende bevoolen, dat soo wanneer iemandt van de Hollanders gevangen geraeckt geweest sijnde (daernae) in handen van de Muslimaens ofte van iemandt (anders) in de gesegende rijcken mochte comen, en dat een Hollander dien persoou begeerde te kopen, ende certificatie van de selve persoon een Hollander te wesen dede, sij dan haer in 't copen van den selve niet te verhinderen hebben; oock en doe niemant van de Muslimaans aen de Hollanderen eenige urgentie, om Muslimaan te werden; dan soo jemant van de Hollanderen met sijn genegentheijt begeerde Muslimaan te werden, dat daerin sijn vrije wil hebbe ${ }^{3}$.

Articul 10.

Item soo versoeck eerbiedelijck, dat soo wanneer tusschen ons en

1 Dit is iets anders dan wat artikel 11 op bldz. 188 hiervóór zegt.

2 Nl. de Nederlandsche "opperste offte president".

s Ook dit laatste komt niet zóó voor in artikel 13 op bldz. 189. 
eenigh andere natie eenige questie mochte comen voor te vallen, soodanigh dat van die beide natie ijemandt doodt bleve, de regenten daermede sich niet te moeijen en hebben, op dat wij haer selfs de verdiende straffe doen erlangen en ingevalle ous volck sonder rede sich met een Muslimaanse vrouwe, vermengde, dat de daroegas dan dien persoon in onse handen leveren, opdat wij hem (selfs) straffen : sijn gebodt is 't hooghste.

\section{s' Conincx APOSTIL.}

Wij hebben ordonnerende bevolen, dat ingevalle tusschen een Muslimaan en een Hollander eenige questie voorviel ende desen Hollander dien Muslimaan quam te dooden, desen dootslager dan in handen van de Hollanderen leveren, opdat sij dien persoon selfs ter doodt brengen, dogh soo se, daeromtrent oochluijcking gebruijckende, dieu persoon ter doodt niet en brachten, dat dan den regent van die plaetse met desen dootslager conform het geestelijck recht te handelen heeft ' , ende bij aldien dese manslagh aen dien Hollanderen gebeurde, dat dan desen Muslimaan aan haer(Hollanderen) ter handt te stellen hebben, die dan in plaets van haer (gedoode) met desen persoon, soodanigh als begeren, handelen sullen moogen ende ingevalle tusschen een Hollander en een Muslimaanse vrouwe eenige vermenging voorviel, dat dan de daroegas van die plaetse desen persoon in handen der Hollanderen te leveren hebben, om hem sijn straffe naer verdienste selver te doen erlangen, ende soo wanneer hem sijne straffe naer verdienste niet en mochten doen erlangen ende daer omtrent ooghluikinck quamen te gebruijcken, dat dan den daroega conform het geestelijcke recht ende justitie met hem te handelen heeft.

\section{Articul 11.}

Nogh soo versoeck eerbiedelijck dat aengaende het overlijden van imant uit voorschreven natie in dit rijck residerende, een gemeene plaets tot begraving van deselve magh aengewezen en geordonneert werden, op dat dese overledene naer haer wijse en costume mogen worden begraven, sonder daar in haer eenige moeijelijckheijt toe te brengen : sijn gebodt is 't hoogste.

\section{'s CONINCX APOSTIL.}

Wij hebben ordonnerende bevolen dat een (soodanige) plaétse omtrent de gemeene grafplaetse van de Sjulfase natie ${ }^{2}$ hebben,

1 Ook deze nadere uitwerking komt niet voor op bldz. 189 hiervóór.

2 Vgl. hiervóór, blz. 190, noot 2. 
omme soo wanneer jemand van haer kome te overlijden, denselven dan volgens haer coustume en wijse te waden en te begraven, sonder dat jmandt van de Muslimaans haar (daerin) verhindere.

Articul 12.

Oock soo versoeckt eerbiedelijck, dat voorschreven natie ter aller plaetse, daerse soude mogen wesen, eer ende respect aen doen, ende de tolcken oock ten aensien van haer dienst volgens 't gebruijck in achtinch houden. Ende soo wanneer iemant hetsij van een Turcx off Inlants geslachte ofte Armenier ofte Benjaen ons begeerde te dienen, dat niemandt haer daer in verhindere: sijn gebodt is 't hooghste.

\section{'s ConincX apostil.}

Wij hebben ordonnerende bevolen, dat d'omeraas, regenten, daroegas, kelaanters ${ }^{1}$ en andere diergelijcke van de gesegende rijken niet en gebreecke en blijven, van aen de Hollantse natie als mede aen haere tolcken eer ende respect aen te doen, en aan haer de behoorlijcke reputatie presenteren, end'een ijgelijck, soo van het Turx off Inlandsch geslachte als Armenier off Benjaen, die de Hollantse natie soude mogen begeeren te dienen, en werde daerinne niet verhindert, onder dese reserve nochtans dat haer geen urgentie instantie tot de Messiasse religie en doen, en deselve in haer eijgen religie laten.

Articul 13.

Item soo versoeckt eerbiedelijck, dat ingevalle een schip van voorschreven natie op Hormoesz off eenigh ander plaatse, dewelcke aen den hoogh aenzienelijcke prince mochte onderhoorich wesen, door storm quam te verongelucken, end in handen der onderdanen van sijn hoogaenzienlijcke prince verviele, dit goet dan in bewaring nemen en houden end'aenden eijgenaer te restitueren hebben: sijn gebodt is 't hooghste.

\section{'s Conincx APOSTIL.}

Wij hebben ordonnerende bevolen, dat in soodaniger voegen als sij (Hollanderen) versocht hebben, effectueren, sonder daertegens eenige contraventie te practiseren.

\section{Ar'Ticul 14.}

Oock soo versoeckt eerbiedelijck, dat soo wanneer voorschreven natie eenige paerden, camelen ende (?) benodicht sijn, deselve dan

1 Volgens een aanteekening in Contractboek Amsterdam III : "een hooft van een gemeente". 
coopen en met haer vervoeren mogen, sonder dat imandt aan haer daerover molestie aen doe, ende dat van de goederen ende coopmanschappen, dewelke in dese tijd met ons gebracht hebben, in 't weder terugh brengen van deselve niemant in Sjieraaz, Bender ${ }^{1}$, Laer en Hormoes eenige raadarije off tol vordere : sijn gebodt is 't hooghste.

\section{'s ConincX apostil.}

Wij hebben ordonnerende bovoolen, dat buijten de paerden, die sonder consent niet en connen vervoert werden, en buijten 't geene dat daer en boven noch verboden is, alles wat sij begeeren koopen en vervoeren mogen, sonder dat jmandt haer daer in verhindere; en wat aengaet de raaderije, soo effectueren soodanigh als op het tweede articul ordonnerende bovolen hebben, en belangende het geen men (wegens die gerechtigheijt) in Laer en Bender Hermoez ${ }^{2}$ neemt, alsoo de saecken van die quartieren aen den toevlucht van heerschappije en dapperheijt, den handtaengreep van respect en luijster, den hoogh verhevene van staet, den vorst der vorsten, de snoer van heerschappije en hooge fortuijn, imaan Cholie Chaan, beglerbegie van Fars, Laar en Koel Gieleejeh ${ }^{3}$ bevelende opgedragen hebben ${ }^{4}$, dierhalve accorderen met hem voorschreven hier over, sullende hetgene met hem vooren geaccord $^{t}$ sal werden, van waerde gehouden werden, sonder dat daerover eenige questie off verschil staet te vallen.

\section{ARTICUL 15.}

Nogh soo maeckt eerbiedelijck bekent, dat met believen van Godt naer desen een Hollandsche ambassadeur aen den Hemels gelijcke throon te verschijnen staet en soo dese nogh eenige andere versoecken buijten degeene die hier haer dienaer gedaen heeft voor te dragen sal hebben, daer van blijft het bevel aen den prince; alsoo mijne princen en heeren dit van mij onderdanige begeert hebben, is het oock nootsaeckelijck, het selve aen Sijn Maijt eerbiedighlijck bekent te maecken: sijn bevel is 't hoogste.

\section{'S CONINCX APOSTIL.}

Soo wanneer een ambassadeur wegens den staetverhevene Hollandse coninck van sons hooftdecksel aen het Hoge Hoff sal comen, dan

1 Bender Abbas = Gamrom.

${ }^{2}$ Bender en Hermoez?

3 ?

${ }^{4}$ Vgl. hiervóór, bldz. 184, noot 2; bldz. 191 en noot 2. 
geve eerbiedelijck te kenne alle sijne redelijcke versoecken en begeeren, die sal mogen hebben, sullende op de versoeken van hem dan ordonnerende bevelen, hetgene volbracht staet te werden.

Boven dit versoeckschrift met sijne apostillen aen de slinker hoeck stont het generale besluijt over al voorschreven articulen in deser voegen als :

\section{S. van den Diwan als vooren.}

In soodaniger voegen, als op de 15 articulen ten dienstiger antwoordt gepast is, effectueren sij sonder tegens dit bevolene eenige contraventie te practiseren, en erkenne dit voor een saecke van gehoudenisse. Geschreven in de (maend) Ziel-Huzjah den Heilige des jaers 1032 naer de vlucht Muhammeds uit Mecca naer Medienech. Overeencomende met de maent ${ }^{1}$ des jaers 1623 naer Christi geboorte.

Achter op den dorso boven aen naer de slincker hoek stondt: bij de hooge boven al verhevene mondelijcke ordonnantie.

En hier onder: L. S. van den Atimaad Dauleh ${ }^{2}$ in die tijt.

Ende leeger: Hier van is een verbindschrift in bewaringh.

Voorts boven in de binnen sijde recht over het voorschreven generael besluit van den Coninck Abbaas de grote nae de slincker sijde toe stondt de confirmatie en vernieuwingh van de voorschreven articulen door den coninck Safie d'eerste ${ }^{3}$ gedaen in deser voegen aldus. ${ }^{4}$

Daer is een van de werelt te gehoorsamene gebodt geschiedt, namentlijck dit:

Alsoo in desen tijt de Hollantse natie de voorschreven articulen in 't gesegende gesicht van mij, hoogh aensienelijcke prince, gebracht heeft, soo hebbe uijt oneindelijke gunsten jegens voorschreven natie aen d'inhouden van voorschreven articulen van d'eerste aff tot de laeste toe een hoogh aensienelijke confirmatie en vernieuwingh gebiedende gevoegt; 't is dan noodsaekelijck dat niemant daertegens en practisere, ende d'innehouden van deselve voor geconfirmeert en vernieuwt erkenne, en achten dit voor een saecke van nootsaeckelijckt

1 Oningevuld. - Dzoe'lhiddjah 1032 loopt van 26 September tot 24 October 1623. - Vgl. hierbij hiervóór, bldz. 183, v.v., bldz. 185, noot 6 en bldz. 191 , noot 4.

${ }^{2}$ "Vertrouwder des rijex" (Dagh-Register 1643-1644, bldz. 189).

s Sjah Abbas' opvolger.

4 Hier volgt nog in het handschrift: „De plaets van het cleine segel des coninx Safie de Eerste". 
achtervolging. Geschreven in de maend van de Heijlige Muharrem des jaers 1040 (naer de vlucht Muhammeds uijt Mecca naer Medienach), overeencomende met de maendt April des jaers 1629 naer Christi geboorte ${ }^{1}$.

Voorts achter op de ruchsijde naer de slinckerhandt schuijns ter sijden van het segel des voorschreven Atemaad Dauleh Saroe Takie om voorschreven articulen te confirmeren en vernieuwen met deze woorden aldus:

In soodaniger voege als het bevelschrift van den prince Hakaan ${ }^{2}$ des vreuchden plaetse in de binnensijde uijtgegaen is, aldus schrijven volgens 't hooghste gebodt in deselve binnenzijde mede een mandament van confirmatie en vernieuwingh.

Hiernevens en dicht aen stondt de paraphure en ondertekening van dien Atemaad Dauleh aldus: Slave van 't Hoff, Muhammed Takie.

Aen de rechtersijde naer de kant toe stondt bij de hooge bovenal verhevene mondelinge ordonnantie. En daer schuijns boven het ordinaris devis van $d^{\circ}$ Atemaad Dauleh als: Ick heb op Godt vertrouwt.

Hier onder het woordt Cholaseh.

En een weinigh leger het segel van den Ahmaad Dauleh Saroe Takie.

Eijndelijck in de binnensijde tusschen het generael besluijt van den coninck Abbaas de Groote en het vernieuwde mandament van den coninck Safie de Eerste is het bevelschrift der confirmatie cn vernieuwing van voorschreven articulen door den coninck Abbas de Tweede gedaen, sijnde van een ende selve woorden als het mandament van confirmatie en vernieuwing des coninck Safie de Eerste voorschreven, hebbende geen andere onderscheijt als in het zegel en den dato, sijnde hetselve met het kleine segel van den Coninck Abbas de Tweede ${ }^{3}$ gecacheteert, ende den dato voorgevallen in de maendt van den respecterende Rezjeb ${ }^{4}$ des

1 Dit klopt niet. Moeharram 1040 loopt van 10 Aug. tot 8 Sept. 1630. Maar ook deze tijdrekening strijdt met de berichten uit Perzië van onze vertegenwoordigers aldaar, volgens welke in 1631 en 't begin van 1632 de privileges van Abbas den Groote nog niet door zijnen opvolger waren bevestigd (Zie hiervóór, bldz. 254 en Dagh-Register 1631-1634, bldz. 88).

2 "Dit is de eertijtel van den Coninck Safie d'eerste", zegt ons handschrift.

3 Sjah Sofi overleed den 11 Mei 1642 en werd opgevolgd door zijnen oudsten zoon, Abbas II (Vgl. Dagh-Register 1643-1644, bldz. 174, v.).

4 Radjab 1052 loopt van 25 September tot 24 October 1642.

Aan het slot van het handschrift wordt nog melding gemaakt van de registratie van deze bepalingen, enz. Ik laat dit alles hier weg.

Dat Augustus in de Nederlandsche vertaling onjuist moet zijn, blijkt ook uit Dagh-Register 1643-1644, bldz. 175, v. 
jaers 1052 (naer de vlucht Muhammeds uijt Mecca naer Medienach). Overeencomende met de maendt Augustus des jaers 1642 naer Christi geboorte. ${ }^{1}$

\section{Cxlvit. Palembang.}

\section{0ctober $1642{ }^{2}$.}

Na de overeenkomst van 21 Juni 1641 (hiervóór, bldz. 347 v.v.) werd al spoedig een nadere regeling der verhouding tusschen de O. I. C. en Palembang in 't belang harer staatkunde noodig. Mataram toch, met welk rijk zij op gespannen of vijandelijken voet stond, trachtte zijn invloed op verschillende deelen van den Archipel, o. a. in Palembang, te vestigen of uit te breiden. Bij die pogingen nu vond het de O. I. C. tegenover zich. Jeremias van Vliet, op weg naar Malaka, na eene vijandelijke ontmoeting (den 5 October 1642) met eene aantal Javaansche vaartuigen "omtrent Palembang", ging met zijn vloot van 7 schepen daarheen en heeft „den Coningh die sich al vry vreemt hadde aengestelt, tot reden gebraght en bondigh contract met hem gemaeckt, dat meer uyt ontzagh als liefde nacomen." Van Vliet had van de autoriteiten te Batavia in last gehad, „omme een missive ende geschenck aen den Pangeran over te leveren ende te vernemen waer toe Sijn Hoocheijt inclineert, ofte sich bij den Mattaram voeghen ofte de vruntschap met $\mathrm{d}^{\prime} \mathrm{H}^{\mathrm{r}}$ Generael vervolghen ende den handel als voor desen toestaen wilt". De Pangeran koos eieren voor zijn geld, waartoe wel zal habben mêegewerkt, dat de Javaansche vloot door Van Vliet op de vlucht was gedreven. En - deze vloot had den pangeran van Palembang, die den vorst van Mataram in zijn rijk had bezocht, weder terug "gecon-

${ }^{1}$ In Contractboek Amsterdam III vind ik nog: 10. een "Bevelschrift wegens het contribueeren van alle billicke en redelijeke hulp aen de Hollanderen, in het invorderen van hare uijtstaende schulden, mits te vooren daervan behoorlijeke notificatie volgens de geestelijcke regten doende; verleent op de daroegas en regenten van alle plaetsen, door den coninck Safie d'eerste, en vernieuwt door den coninck Abbaes de Tweede in de maendt Resjeb des jaers 1052", waaruit blijkt, dat de O. I. C. "eenige redelijcke schulden onder de Zjulfaers en andere uijtstaende" had. Ik meen het stuk hier te kunnen weglaten.

$2^{\circ}$. Een ${ }_{\text {Translaet Commandem }}{ }^{\mathrm{t}}$ door Sijn Maijesteit Abbaes aen de Heer Directeur Wollebrant Geleijnse, over dat de inlandtse dienaers, die sonder consent weghloopen ons weder in handen werden gestelt, om eerst haer licentie te obtineren, verleent $A^{\circ} 1642$ ", welk stuk ik evenmin opneem.

Evenmin deel ik hier mede enkele andere stukken uit bovengenoemd contractboek, over den aankoop van huizen, enz. van 1629 enz., die van ongeveer denzelfden inhoud zijn als andere door mij wèl medegedeelde, en die geen nieuws overigens geven voor ons doel van belang.

2 Uit het Contractboek. 
voyeert"! Zoo was er een schijn van waarheid gekomen over Van Vliet's bewering in Palembang, dat de G.G. „niet meer werck (maecte) van den Mattaram als den oliphant van een mugge ofte miere mach doen" (Vgl. Heeres, Bouwstoffen, III, bldz. XLII, 108 v.v., waar 't contract ook is afgedrukt; De Jonge, Opkomst, V, bldz. 256, v.; Mac Leod in Indische Gids, 1903, bldz. 1923-1929; onuitgegeven ress. G.G. \& R. 2 Juli, 22 Aug. 1642, missive G.G. \& R. aan Van Liesveld te Palembang 29 Maart 1642, aan den Pangeran, 29 Sept. 1642, instructie van G. G. en R. voor Van Vliet, 29 September 1642, journaal van Van Liesveld op de Bredamme (een der schepen van de vloot onder Van Vliet), 30 Sept. - 20 Oct. 1642 ; res. van „den secreeten raadt der vlote", 22 Oct. 1642, enz.).

Accoordt ende contract tusschen Edelen Heer Anthonio van Diemen, gouverneur generael over den standt der Vereenighde Nederlanden jn Jndia Orientalis ter eener ende s Jebingh Palimbang, pangaran over Palimbang ende 't eijlandt Bancka etc ${ }^{\mathrm{a}}$, gemaeckt met voornoemden pangaran bij ons, Jeremias van Vliett, commissaris ende extraordinaris gesant aen Sijn Hoogheijt, Ariaen Liesvellt, oppercoopman ende hoofft van de Nederlandsche commertien in Palembang ${ }^{1}$, beijde daer toe geauthoriseerdt van sijn wellgem $^{\text {ten }} \mathrm{Ed}^{\mathrm{e}}$, ende den oppercoopman Drieck Snoeck, wellck contract onverbreekelijck ende voor eeuwigh wesen sall.

Eerstelijck sall den Pangaran toelateu, volgens d'acte van den cap $^{\mathrm{n}}$ Pieter Sourij in November 1640 verleent ${ }^{2}$, dat de Nederlandtsche Comp ${ }^{e}$ in Sijn Hoogh ${ }^{t}$ hooffstadt Palimbangh op de vergunde plaetse, streckende O. Z. O. aen de overcandt langhs de reviere, van sulcken lenghte ende breete als noodigh hebben, op hare cossten laten bouwen ende doen maken sall soodanigen magasijn, 't zij van houdt offte steen, als den Capiteijn Generael sall goedt vinden ende gelieven te ordonneeren.

Den Pangeran sall niet vermogen, eenige Portugesen, Javanen, Chineesen offte wat natie 't zellve moghte wesen op 50 vadems omtrent Compe magasijn te laten woonen, maer ter contrarie haer $\mathrm{t}$ zellve verbieden, tenzij met toelaten van 's Comp $p^{8}$ resident.

Des Comp $p^{8}$ dienaeren ende subjecten, $t$ zij van wat natie die zijn offte van waer comen, zullen genieten vrijheijt in de Christelijcke religie, d'sellve onverhindert ende zonder spot exerceren ende in

1 Vgl. hiervóór, bldz. 348, noot 4.

2 Vgl. hiervóór, bldz. 348 en noot 2. 
zoodanigen liberteijt als in Batavia offte eenige plaetsen onder haer gebiedt vermogen te doen.

Niemandt van 's Comps offte des Paugaranghs subjecten sullen vermogen, eenige questie offte dissputatie van religie te maeken offte aen te vangen, op pene dat ijder den zijnen, soo well Zijn $\mathrm{Hoogh}^{t}$ als Comp ${ }^{\mathrm{s}}$ resident, aen den lijve daer over straffen zall.

Zoo ijmandt van 's Comps dienaeren offte subjecten, daer Godt voor zij, tegens de Pangeran, de geestelijck hunne religie ${ }^{1}$ offte Grooten deses rijex sigh soodanig vergrepen, dat 't feijt exemplare straffe meriteerde, zal den Pangeran eghter zulcx niet vermogen executeeren, maer den delinquant met d'jnformatien leveren in handen van Comps resident, opdat denselven nae exgigentie van saeken gestrafft offte nae Batavia gevoerdt ende aldaer in handen van justitie overgeleverdt werde.

Ingevalle 's Comps resident offte capiteijn over de negotie door infadementen ${ }^{2}$ ende vexatien soo geterght wierdt, welck wij niet hopen, dat door swackheidt ende menschelijcke bewegingen hem tegens den Pangeran, geestelijcken offte de Grooten deses rijex in eenigerleij wijse vergrepe, sall den Pangeran noghte niemant sulx vermogen hier te straffen, maer van alles goede informatie nemen ende den Capiteijn Generael sulx aenschrijven, in welcken gevalle Zijn Ed. oock soodanige jusstitie adminisstrere als naer rechten bevint te behooren ende tot Zijn Hoogh ${ }^{t}$ contentement strecken zall.

Zoo ijmandt van 's Comps subjecten offte leijffeijgenen bij den Pangeran overloopt, 't zij sulx uijt oorsaeke offte opgenomen haet tegen zijne overheeren geschiedt offte sigh ergens soeckt te borgen, sall Zijn Hoogh ${ }^{t}$ gehouden wesen, desellve op te doen soecken ende over te leveren in handen van 's Comp ${ }^{8}$ resident.

Offt gebeurde, 't welck Godt verhoede, dat eenige jngeboorne offte jnwoonders in Palimbangh, 't zij wat natie offte qualiteijt die zouden mogen wesen, hun verstouten, 's Comps resident, sijne minderen, offte eenige subjecten van den Nederlandtschen staet hoon offte smaet aen te doen offte schelltwoorden tegens haer uijt te spouwen, zall Zijn Hoogh ${ }^{t}$ allsulcke dadelijck naer meriten doen straffen; soo niet, den Capiteijn jn handen leveren, om naer exigentie van saecken selffs te straffen offte op Bat ${ }^{a}$ te voeren ende bij weijgeringe van jusstitie sall den Resident soodanige mogen in heghte nemen ende handelen daer met soo 't behoort.

\footnotetext{
1 Bouwstoffen, III, bldz. 109: „de geestelijcken hunner religie".

2 Invadementen $=$ wederrechtelijke bemoeiingen van anderen?
} 
Des Comp ${ }^{s}$ dienaren, vassalen ende subjecten onder 't gebiedt van den Capiteijn Generael, die hier comen negotieren, zullen betalen van alle cleeden, die geopend werden, jder sorteringe een stuck zonder meer; ende van den peper, die uijt Zijn Hoogh ${ }^{t}$ rijck vervoerdt zall werden, hondert vijff $R^{\mathrm{a}}$ van $8^{\mathrm{n}}$ in spetie van jder hondert pijcoll, te weten taghtigh $\mathrm{R}^{\mathrm{a}}$ voor den Pangeran ende vijff en twintigh $d^{\text {os }}$ aen den Sabander, die tot dat ambt geadmitteerdt is offte gebruijkt werdt, welcke gereghtigheijdt ende ${ }^{1}$ Pangoran ende Sabandar bij manquement van penningen in cleden mercktganck sullen aannemen ende haer daer met laten contenteren.

Alle coopluijden, borgelijck ende gemeene persoonen, egene uitgesondert, sullen vermogen met 's Comps residenten te handelen, coopen ende vercoopen in alle coopmanschappen ende goederen, sonder dat ijmandt sulcx sall beletten offte verhinderen.

Den Pangeran zall zijne jngeboornen ende jngesetenen, 't zij Chineesen offte andere natien, daer met 's Comps residenten handelen, aen doen condigen, dat niemandt cleeden noghte comptanten sall verstreckt werden, eer d'sellve peper aen boordt hebben geleverdt en principalijck niet aen de Grooten van 't rijck, omdat men daer mede de meeste moeijten heefft en 't weijgeren onlusten veroorsaeckt, ten ware de Pangeran dacr selffs voor willde ressponderen.

Soo 's Comps resident noghtans goedt vont, aen Chineesen offte ijmandt cleden ende comptanten voor alleer dat peper leveren te vertrouwen, sall voornoemde resident bij manquemendt van tijdelijke ${ }^{2}$ betalinge vermogen, soodanige luijden 't scheep gevanckelijck setten ende voor 't vertrek niet volldoende, nae Batavia voeren, sonder dat Zijn Hoogh ${ }^{t}$, schoon 't jngeboorne zijn offte Chineesen, die hun ouder Zijn Hoogh ${ }^{t}$, de Coninginne offte eenige Grooten hadden begeven, 't sellve in eeniger manieren sall beletten, maer ter contrarie alle devoir aenwenden, d'onse satisfactie geschiede.

Den Pangeran sal niet toelaten, dat eenige natie peper uijt sijn landt vervoere als alleen 's Comps dienaren ende hare subjecten offte zijn jnwoonders, mits dat sij d'sellve op $\mathrm{B}^{\mathrm{a}}{ }^{3}$ brengen, allwaer hun goedt onthael aengedaen ende in alles geaccommodeert sullen werden. Jngevall den uijtvoer van peper bij 's Comps residenten vermerckt werdt, sullen vermogen alles te lighten, allwaerdt binnen de rivier offte hier ter rheede.

1 Bouwstoffen, bldz. 110, heeft hier: "den".

2 In de beteekenis van "tijdige".

3 Batavia. 
Des Comp ${ }^{8}$ resident sall d'authoriteijt ende 't gesagh hebben over alle Batavische Chineesen en 's Comps subjecten, die met jonquen offte vaertuijgen hier verscheijnen; soo d'sellve qualick doen, straffen ende soo ijmandt hun verongelijckt, voorstaen ende reght vorderen ende soo eenige fugitieven, van $\mathrm{Bat}^{\mathrm{a}}$ offte andere plaetsen gevlucht, gewaer werdt, hun sonder eenige contradictie weder mogen vervoeren.

Alle vaertuijgen, 't zij wadt natien die zijn en van waer dat comen, sullen hunne pasceduls van voornoemden resident vorderen. Eghter soo ${ }^{1}$ gemelte resident geen passceduls geven aen die om d'Oost vau Java offte voorbij Malacca willen, maer soo den Pangeran 't aenstaende Noordermousson voorneemt, drie à vier vaertuijgen om de Oost van Java te senden, sall $\mathrm{S}^{\mathrm{r}}$ Liessvelt passen verleenen, dogh int aenstaende sall Zijn Hoogh ${ }^{t}$ sulx aen $\mathrm{d}^{\prime} \mathrm{H}^{\mathrm{r}}$ Generael ${ }^{2}$ moeten versoeken. Jngevall eenige vaertuijgen bij Noorden Malacca willen varen, sullen die rheede eerst aendoen ende alldaer een passcedull van den Gouverneur ${ }^{3}$ versoecken ende soo 's Comps schepen offte hare subjecten eenige vaertuijgen bij Noorden Malacca offte d'Oost van Java sonder passen bejegenen, sullen voor goeden buijt aengeslagen werden.

Des Pangerans jngeboornen ende subjecten zullen vermogen, met passen van 's Comps resident van hier nae Johor, Pahangh, Patanij, Siam ende Cambodia te varen, met zoodanige coopmanschappen die de Comp ${ }^{\mathrm{e}}$ niet prejudicabell zijn, maer sullen geen peper derwaerdts voeren; offte soo contrarie bevonden werdt, sall 's Comps resident de vaertuijgen jn dese reviere zijnde, den peper daeruijt mogen lighten; in zee onse scheepen bejegenende, aengeslagen ende voor goede buijt verclaerdt werden.

Jngevalle 's Comps schepen offte hare subjecten eenige vaertuijgen, van waer dat comen, met maintementos offte geringe coopmanschappen tusschen Lucepare * en Linga bejegenen, die 't voornemen nae Palimbangh hebben, zijlieden soodanige vaertuijgen volgens 't contract, met den capt $^{\mathrm{n}}$ Sourij voor desen gemaeckt ${ }^{5}$, vrij en lijber laten passeren, dewijle Palimbangh sijn voetsell van sout, rijs ende meer behoefftigheden uijt ander landen hebben moet, maer

\footnotetext{
1 Bouwstoffen, bldz. 111: „eghter sal”.

2 Gouverneur-Generaal.

s Van Malaka. De handelspolitiek, door de O. I. C. in Malaka gevoerd, wordt hier toegepast op de vaartuigen van Palembang.

4 Luciparapunt.

5 Vgl. hiervóór, bldz. 348.
} 
soo d'selve nae andere plaetsen tenderen, sullen 's Comps scheepen offte hare subjecten, als selffs voor de Palimbanghse reviere, zeehaven ende plaetsen onder 't gebiedt van den Pangoran, mogen aenslaen ende voor goede princen houden.

Des Comp ${ }^{8}$ dienaren offte hare subjecten sullen binnen de Palimbanghse reviere ${ }^{1}$ geen handelaers beschadigen, maer soo binnen voornoemde reviere offte in de Palembanghse strate 2 eenige oorloghsvaertuijghen van den Mattaram ${ }^{3}$ bejegenen, moge d'sellve vrijelijck aentassten, sodanigen hostiliteijt thoonen ende beschadigen aen schepen, volckeren ende goederen, sooals te rade werden sullen.

Den Pangeran sall voortaen sodanige bontgenoot en geallieerdt vrundt vau den Capiteijn Geuerael ende Nederlantschen staedt sijn, eeuwigh en onveranderlijck blijven, dat niet vermogen sall, hunne vijanden in eeniger manieren t'assisteeren, maer ook voor vijanden houden ende doen houden ${ }^{4}$, die haer hosstijle possture tegen sijn Ed., sijne dienaers, hunne commertien offt subjecten stellen off doen stellen op pene van ook in vijantschap met den Nederlandtschen staedt te vallen. Jntegendeell sall den Capteijn Generael den Pangeran in alle toevallen adsisteeren ende tegen zijne vijandeu soodanigh protegeeren als den noodt vereijschen, 's Comps maght toelaten ende de gelegenheijdt aenwijsen zall.

Tot besluijt beloofft den Pangeran mits desen, dat ons binnen zijn riviere in alle swarigheden ende voorvallen sall beschermen jegens alle gedughte offte openbare vijanden ende geveijnsde vrunden, die 's Comps dienaeren offte hare subjecten met gewellt offte practijcken eenige hinder souden willen mogen offte connen aendoen. Welck contract ter wederzijden met onse handtteekens becraghtight is.

Int schip de Luijpaerdt in de reviere voor Palimbangh desen $20^{\text {en }}$ October $\mathrm{A}^{\circ}$. $1642^{5}$.

1 De Ajer Moesi.

2 Straat Banka.

3 "Den Mattaram" wordt steeds gebruikt in die dagen voor den vorst van Mataram.

4 Dus ook Mataram.

5 Het (onuitgegeven) journaal op de Bredamme, een der schepen van Van Vliet, door Adriaan van Liesveld gehouden, zegt, dat het contract werd onderteekend den 21 October, op welken dag ook de plaats werd aangewezen, waar de O. I. C. een loge zou vestigen: palen met 's Comps wapen werden opgericht. De Palembangers drongen aan op het bouwen van een sterkte in hun land. „Bovendien dronghen seer stercq aen om doorgaens een schip voor dese staet te mogen liggen hebben" ( Van Liesveld aan den G.G., 26 Oct. 1642). Den 22 Oct. werd besloten, dat Van Liesveld met twee schepen voorloopig in Palembang zou blijven.

7e Volgr. III. 
Dit contract is met drie zeegells becrachtight, namentlijck van Sjebiugh Plimbangh, pangerangh, radingh tommagon, eerste, ende keaij tammagon Nazza Pra Radie, derde persoon int rijck; ende onderteekent bij Jeremias van Vliedt, Adriaen van Liesvellt, Dirck Snouck, neffens hunne wapens in rooden lack daer op gedruckt.

\section{FORMOSA.}

1642. ${ }^{1}$

Vóórdat aan den gouverneur van Formosa bekend werd, dat de: Spaansche versterking van Kelang, den 26 Augustus 1642, in handen van de onzen, onder bevel van Harousé, gevallen was (vgl. hiervóór, $\mathrm{N}^{\circ}$ CXLV), had de gouverneur, Traudenius, den sergeant-majoor Lamotius, juist met versterkingen uit Batavia gekomen, naar Kelang gezonden met 3 jachten en een "quelpaert", 2 om daar de opperleiding te voeren. Zijne instructie, door Traudenius geteekend, is van 7 September 1642. Vooral de verwachte goutmijnen, "het langh gewenschte desseijn", zouden nà de eventueele verovering van het Spaansche fort het hoofddoel zijn. Hij moest die trachten te bereiken, n't sij bij wege van minne.... ofte wel met macht van wapenen". Het laatste zou wel het geval zijn: "want het schijnt, dien brutalen hoop (nl. de inlanders van Kelang-Tamsuij, "die almede den beest spelen") niet met vruntschap, maer met force van onse waepenen tot reedelijckheijt moeten worden gebracht". Verder moest hij het land voor de O. I. C. in bezit nemen. Een garnizoen moest. in het eventueel veroverde Spaansche fort blijven (Vgl. deze Bijdragen, Nieuwe volgreeks, II, bldz. 92 , v.v.). Een der resultaten van Lamotius' tocht is onderstaand verdrag.

Artijkelen ende conditien, d'welcke door den velldtoverste Joannes Lamotius ende den Raedt op Quelangs inwoonders van Formosa voorgestellt zijn ende ook aengenomen ende beloofft hebben t'aghtervollgen, om onder onse bescherminge ende in ons verbandt te mogen aengenomen werden.

Ende eerstelijck dat zij aen de Nederlanders hun landt ge-

1 Uit het Contractboek. De datum staat niet geheel vast, maar moet eenigen tijd later zijn dan 7 September, de dag waarop Lamotius' instructie door den gouverneur van Formosa is vastgesteld (Vgl. deze Bijdragen, Nieuwe volgreeks, II, bldz. 98. - Vgl. hiervóór, bldz. 368, v.). In het Contractboek bevindt zich het stuk dan ook na het contract met Palembang van 20 October 1642 .

2 Wie kent de afleiding van dit woord? 
willighlijck ende bereijdt zijn op te dragen, sulcx metter daetzullen doen blijcken, nu ende ten eeuwige dage ende voorts deselve natie gehou ende getrouw te blijven.

Dat geen wapenen tegens ons ende niemandt van onse geallieerde vrienden ende bondtgenooten noghte tegens den geenen, allwaer wij ende zij tegenwoordigh mede vereenight zijn en zullen aennemen offte gebruijcken om geenderleij aorzaeke, maer ter contrarie alle hullpe, faveur en bijstandt met goedt ende bloedt te betoonen; ende specialijck eenige van onse offte van onse geallieerde met hun jaghten, offte ander vaertuijgh op hare strant te vervallen en te verongelucken, dat alsdan deselve hunne leven ende vaertuijgen getrouwelijck sullen hellpen bergen en ter naesster plaetse van onse guarnisoen offte fortressen te hellpen brengen.

Dat zoo wauneer een princevlagge met een ciap offte merck, gelijck haer mede gegeven is, in haer dorpen wert verthoont, hunne outste ende oversten terstondt aent cassteell op 't eijlandt Quelangh sullen verscheijnen, omme te aenhooren en nae te comen sodanige ordre en lasst als hun bij de resspective overheden alsdaer sall werden gegeven.

Dat mede jngevalle de jagers offte ijmandt van onse geallieerde bondtgenooten in ende ontrent haer plaetse moghten comen te vervallen, sij deselve weder sullen te reghte brengen, sonder eenige hinder offte jmpechement te doen ende ter contrarie alle weghgeloopen en gevlughte swarten en aendre vrije offte lijffeijgenen, die zij souden mogen vernemen, terstondt ende sonder vertoeven, soo in der minne als met gewellt, ende in cas van groote opositie dersellver hooffden offte coppen van ' 't voorschreven Quelangh offte ellders allwaer die thuijs hooren sullen brengen, waer voor hun een redelijcke recompense sullen genieten.

Dat jnsgelijck gehouden zullen zijn, soo wanneer wij met eenige jnwoonders in oorloge quamen te geraeken, ons met hun groote maght en t'onser eerste requisitie comen assisteeren, 't welck wij jnsgelijcx tegens hare vijanden tot hun bescherminge sullen doen, behoudelijck dat den oorlogh in rade bestaen, ende met onse keunisse bij der handt genomen werde.

Eijntelijck dat alle de naesstgelegen dorpen eens ter weeke ende de veerste eens alle 14 dagen allhier met aerdt ende boomvrughten, alsmede met hoenderen, eijeren, visch, groot en kleijn beesstiaell op den passer om te venten sullen verscheijnen, welcke goederen

\footnotetext{
1 Schrïffout voor: „aen"?
} 
hun in redelijckheijt affgekofft ende met gelldt, kleeden offte andere waren en goedduncken ${ }^{1}$ sullen volldaen ende betaellt werden.

Eijndelijck ende ten lessten allsoo dese artijkelen tot ende op approbatie van onse hooge overigheijt geslooten ende beraemt zijn, zoo sullen d'jnwoonders offte hoofden van dien alle veranderinge, welcke niet anders als in redelijckheijt bestaen sall, mede gehouden zijn aen te nemen ende accepteeren, gelijck deze bovenstaende artijkelen mede gedaen hebben.

\section{SURAT.}

\section{November-3 December 1642. ${ }^{2}$}

Sedert de verkrijging der fermans van 1636 van den Grootmogol betreffende den handel in Surat en vandaar uit in Hindostan en verdere deelen van het rijk van den machtigen heerscher (zie hiervóór, bldz. 278 , v.), was de O. I. C. in die streken haren handel blijven voortzetten. Toen echter in Augustus $1634^{3}$ G.G. en Raden besloten, Jacob van der Graeff (vgl. hiervóór, bldz. 278) te vervangen door Barend Pietersen (vgl. hiervóór, bldz. 276, noot 1), werd aan den nieuwen vertegenwoordiger der O. I. C. niet gegeven de waardigheid van Directeur. Hij zou daar gevestigd zijn ,in qualitee van oppercoopman, sonder meer tijtel te gebruijcken". Deze maatregel stond zonder twijfel in verband met het oordeel der Hooge Regeering over het belang der commercie in die streken, die zij toen noemde „den onprofijtelijcken Indostansen handel, veroorsaeckt door des Conincx monopolie in den indigo ende de dierte der cleden." (Dagh-Register 1631-1634, bldz. 368, v.). Toen Pietersen op het eind van 1639 aftrad (hij werd vervangen door Paulus Crooeq: vgl. onuitgegeven Generale missive, 18 Dec. 1639), was echter de directeurs-titel reeds geruimen tijd (minstens sedert 1637: vgl. Dagh-Register 1637, bldz. 264) weer hersteld en Croocq werd Directeur. Onze betrekkingen met die streken waren dan ook van meer beteekenis geworden, dank ook de leiding van den bekwamen Pietersen (vgl. onuitgegeven Generale missive, 30 Nov. 1640; Dagh-Register 1637, bldz. 81, 103, 264 v.v.; 1640-1644, passim). Toch wordt steeds door onze vertegenwoordigers geklaagd over tegenwerking en vexatiën van verschillende plaatselijke autoriteiten, vooral ook ten opzichte der tollen, en het was vooral om daarin verbetering aan te brengen, ,tot voorcominge van veele onredelijcke fastidiën", dat in 1642 de opperkoopman te Agra,

1 Hier is de tekst bedorven.

2 Overgenomen uit Dagh-Register 1643-1644, bldz. 168, 169.

3 Ik heb op bldz. 278 het jaar van Van der Graeff's aftreden (1634) niet genoemd, wat misschien tot eenige verwarring zou kunnen aanleiding geven. Ik maak daarom van deze gelegenheid gebruik, even op deze aangelegenheid terug te komen. 
Cornelis Weijland, naar het Hof van sjah Jehan (vgl. hiervóór, bldz. 268 , v.), die toen verblijf hield te Lahore, werd gezonden. Den 19 October werd Weijland tot den Grootmogol toegelaten met geschenken en een brief namens den Gouverneur-Generaal. Verschillende fermans waren het resultaat van dezen tocht (Dagh-Register 1641--1642, bldz. 193; 1643-1644, bldz. 163 , v.v.).

Translaet van 's conincx firman geschreveu den 14 dagh van de maent Chaban, ${ }^{1} \mathrm{~A}^{\circ} 16$ van sijn regeringe ende $\mathrm{A}^{\circ} 1052$ van Mahomet.

Alle groote ende cleijne gouverueurs, heijdense ragies, radaers, thollenaers, wachters op de revieren ende in den weg van Agra tot Souratta toe, sullen verstaen dit volgende gebot van den coninck die de Hollanders seer toegedaen is.

Welcke door hulpe van haere goetgunstige (die staen onderaen de voet van sijnen throon, welcke soo claer is als de son, ende streckt tot aen den hemel) hebben verclaert, dat in ende rondom Agra, Amadaba1h, Brodra ende andere plaetse sijn negotieerende, mits betaleude behoorlijcke tholl, ende gedoleert dat in gemelde plaetsen, alwaer sij coopen ende vercoopen, in de wech, op ider masel ofte rustplaetse, elc dorp, veel geldt van hare caffilas op den naem van tholl ende wachtgelt affgevordert ende veel travaillie aengedaen wert, jae daer met haer caffilas opleggen, somtijts niet segour rusten connen, 't welck Sijn Maijt ter oiren gecomen sijnde, ordineert ende commandeert dat in Souratta ende Brooteha tholl sullen bethalen ende nieuwers anders. Oock sal niemant van haer iets eijsschen, veel min nemen, tsij heijmelijck ofte openbaer. In welcke fausdaers ${ }^{2}$ gebiet comen, sal $\mathrm{d}^{0}$ gehouden wesen hun te convoijeeren tot in een ander sijn gebiet, opdat haer geen schade overcome. Van dit voorschrevene is een firman bij haer, ende andermael op een nieuw gebiet de coninck sulcx.

Haer coopmanschappen, indigo, als anders mogen coopen als 't hun belieft; oock maeckelaers gebruijcken die sij willen ende vermach niemant daervan te participereu.

Datum ut supra. ${ }^{3}$

1 Sjaban 1052 begint 25 Oct. 1642. Het stuk is dus gedagteekend 7 November.

2 Fauj-dar, foujdar, phousdar: een militaire gouverneur, maar ook het hoofd der politie van een district (Hobson-Jobson, p. 273).

3 Ofschoon niet al de aangeschreven gouverneurs, enz. zich veel stoorden aan deze fermans en Werjland dan ook al spoedig besloot, daarover zich weder bij den Grootmogol te beklagen, waren er toch wel degelijk hier en daar gunstige gevolgen van den ferman van November 1642 merkbaar (Vgl, Dagh-Register 1643-1644, bldz. 171, 173, 179, 180, 187, 188, 196). 
Translaet van 's conincx firman, nopende de thollen in Souratten, geschreven den $11^{\text {en }}$ dagh van de maent Rammasan, ${ }^{1}$ van sijne regeringe $\mathrm{A}^{0} 16$, ende van Mahometh 1052.

De Hollanders sijn gecomen voor de poort van 's coninx hoff, ende door hulp van haer favoriten (staende onderaen de voet van sijnen throon, welckers luijster is gelijck de son, ende streckt tot aen den hemel toe) in 't gesichte van den coninck, ende hebben door $d^{\circ}$ favorijte gedoleert, dat sijn dienaer (in Souratta regerende) hun in 't verthollen der goederen die in Agra en Amadabath incoopen ende in Souratta brengen, veele travaillie aendoet ende versocht, dat Sijne Maij ${ }^{\mathrm{t}}$ gelieve door sijnen divan daerop soodanige wijze te stellen, 't welck de tollenaers in Souratte sullen moeten volgen ende soodanigh aen Sijn $\mathrm{Maij}^{\mathrm{t}}$ weder in reeckeninge brengen. Daerop heeft den Coninck gemandeert dat de thollenaers haer goederen, comende van Agra, niet hooger als van 10 op 12, dittos van Amadabath van 10 op $10 \frac{1}{2}$ taxeren ofte cargeren sullen, ende moeten op haer facture vertrouwen ende geen meer tholl ten hondert afnemen als de manier is. De goederen in Brodera ende Soeratta ingecocht sullen volgens den incoop vertholt worden; behalve dit noet haer geen travaille aengedaen, noch iets buijten reden afgevordert werden.

\section{BENGALEN.}

7 November 1642. 2

Ook de handelswegen, welke van Agra naar Bengalen leidden, werden door Weijland bij zijne zending naar Lahore niet vergeten, zooals uit onderstaanden ferman blijkt.

Translaet van's conincx firman nopende de bevrijdinge van de thollen op de wegh in de Poerobs quartieren ${ }^{3}$,

1 Ramadhan 1052 begint 23 November 1642. Deze ferman dagteekent van 3 December, dus van nà het vertrek van Weijland uit Lahore op 24 November (Vgl. Dagh-Register 1643-1644, bldz. 167).

2 Overgenomen uit Dagh-Register 1643-1644, bldz. 170.

s Wat toen onder deze "quartieren" moet worden verstaan, is uit den tekst van den ferman op te maken (het is ongeveer het tegenwoordige Oudh: vgl. Hobson-Jobson, p. 547). Op Hunters Atlas nòch in zijn Gazetteer vind ik de uitdrukking. Wèl op Valentijn's kaart van 't Koninkryk Bengale (V, 1, bldz. 146), nl. ,'t Land van Prurop". Deze kaart is echter zéér onnauwkeurig. 
geschreven den 14 dagh van de maent Chaban, $\mathrm{A}^{\circ} 16$ van sijne regeeringe ende 1052 van Mahomet.

Alle groote ende cleijne gouverneurs, heijdense radgies, radaers, thollenaers, wachters op de revieren ende in de wegh van Pipelij Bandaer tot Agra ${ }^{1}$ toe, sullen verstaen dit naervolgende gebodt van den Coninck die de Hollanders seer toegedaen is.

Welcke door hare vrinden (staende onder aen de voet van sijnen throon, welckers luijster streekt tot den hemel toe ende is de son gelijck) hebben verclaert, dat in Benares, Jaelaelpour ${ }^{2}$, Geijjrebath ${ }^{3}$ ende andere plaetsen negotierende ende gedoleert, dat wanneer sommige goederen naer Agra, ende sommige naer Pipelij brengen, in de wegh op alle plaetse, dorpen ende revieren hun veele travaillie aengedaen wert, hun afvorderende veel gelt, op de naem van thol ende wachtgelt, oft onder eenigh ander pretext, jae sodanige moeijte, dat somtijts qualijck op haer masel geraecken connen. Daerover gebiet den conninck dat alle tholl, wachtgelt ofte diergelijcke in sijne juridictie haer heeft vrijgegeven, dies sal niemant haer daerom eenige molestie aendoen, oock niet van haer eijsschen onder wat schijn het soude mogen wesen, gelijck 't vorige firman dat bij haer berustende is, oock vermelt. Dat in den wegh haer niemant sal verhinderen te gaen soo verre als 't hun sal believen ende blijven daer sij willen. Gebiede andermael, dat alle coopmanschappen mogen coopen, ende maeckelaers gebruijcken die 't hun belieft ende soo iemant dit contrarieert, soodat weder bij Sijne Maij ${ }^{t}$ comen doleren, sal de schuldige opt hoochste gestraft werden. Idereen sal dit met alle vlijt naercomen, soo haest als dit sal gelesen hebben.

Datum uit supra.

1 Agra was dus de plaats, waar de handelsbeweging der O. I. C. in Hindostan zich concentreerde: Z.W.waarts naar Surat, Z.O.waarts naar Bengalen.

2 Vermoedelijk Jalalpoer ten N.W. van Benares.

s Khairabad, ten Oosten van Agra, ten N.W. van Jalalpoer. 